Portland State University

PDXScholar

1993

\title{
The Theory and Practice of Community Policing: An Evaluation of the Iris Court Demonstration Project
}

Charles Moose

Portland State University

Follow this and additional works at: https://pdxscholar.library.pdx.edu/open_access_etds

Let us know how access to this document benefits you.

\section{Recommended Citation}

Moose, Charles, "The Theory and Practice of Community Policing: An Evaluation of the Iris Court Demonstration Project" (1993). Dissertations and Theses. Paper 1331.

https://doi.org/10.15760/etd.1330

This Dissertation is brought to you for free and open access. It has been accepted for inclusion in Dissertations and Theses by an authorized administrator of PDXScholar. Please contact us if we can make this document more accessible: pdxscholar@pdx.edu. 
THE THEORY AND PRACTICE OF COMMUNITY POLICING:

AN EVALUATION OF THE IRIS COURT

DEMONSTRATION PROJECT

by

CHARLES MOOSE

A dissertation submitted in partial fulfillment of the requirements for the degree of

\section{DOCTOR OF PHILOSOPHY \\ in \\ URBAN STUDIES}

Portland State University 1993 
TO THE OFFICE OF GRADUATE STUDIES:

The members of the committee approve the dissertation of Charles Moose presented November 5, 1993.

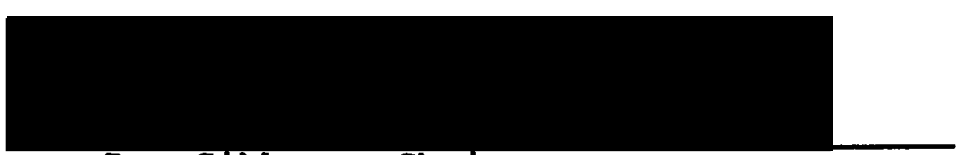

Don Gibbons, Chair

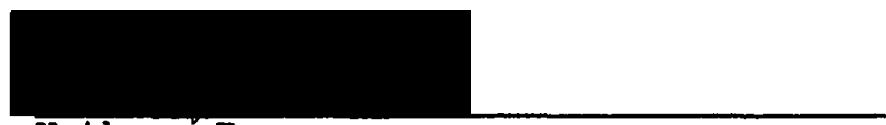

Kathryn Farr
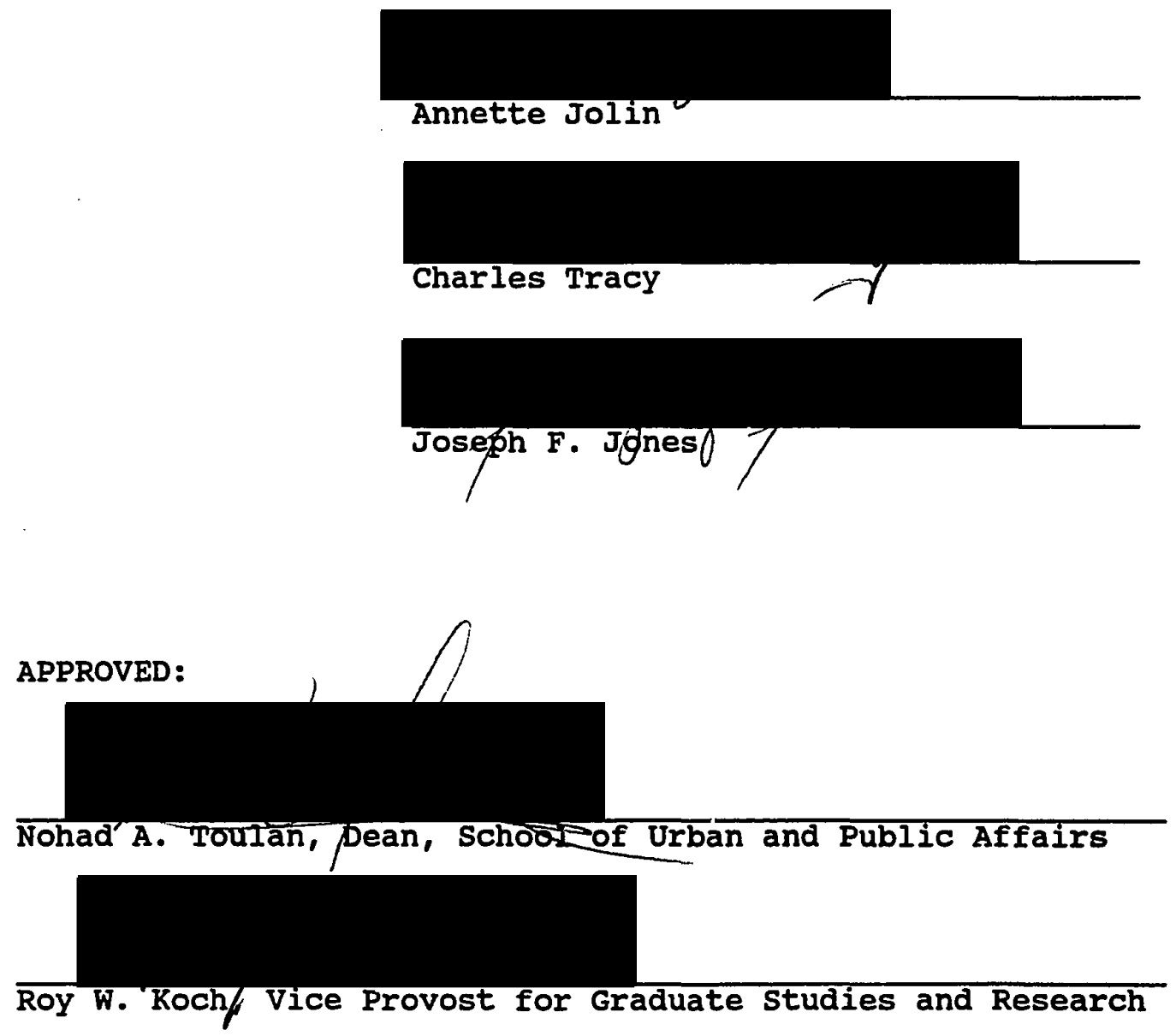
AN ABSTRACT OF THE DISSERTATION OF Charles Moose for the Doctor of Philosophy in Urban Studies presented November 5 , 1993.

Title: The Theory and Practice of Community Policing: An Evaluation of the Iris Court Demonstration Project APPROVED BY MEMBERS OF THE DISSERTATION COMMITTEE:

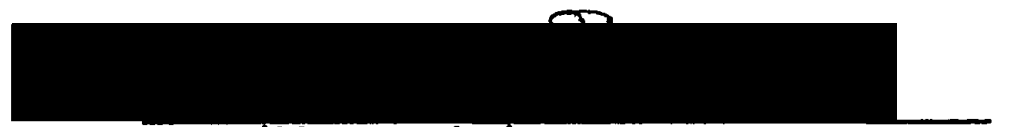
Don Gibbons, Chair

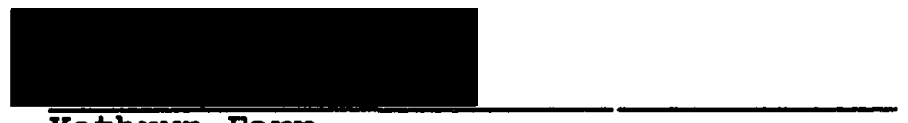
Kathryn Farr
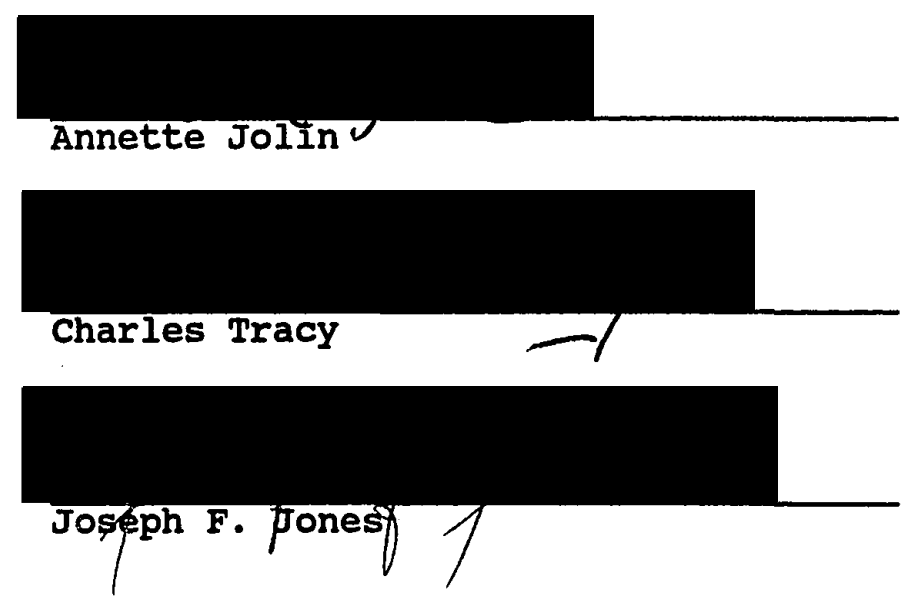

This dissertation deals both with the theory and practice of community policing in the United States and elsewhere while focusing on a specific community policing project in Portland, Oregon. It discusses the history of 
police work in America, as well as that of the Portland Police Bureau. It also explicates the various meanings of "community policing," along with the problems and issues that have surfaced as the community policing movement has evolved.

The research reported here was based on a project conducted by the Portland Police Bureau and numerous supporting agencies. The project was inaugurated in May 1990 with the following goals: improve quality of life of the residents, reduce the fear of crime, and reduce the levels of actual crime.

Iris court is a public housing complex owned and operated by the Housing Authority of Portland. It was recommended as a demonstration site for community policing because of past and ongoing problems of crime in and around it.

The Portland city Council had mandated that community policing become the policing style in Portland, and the demonstration project was intended to test various community policing strategies.

The tenants were surveyed prior to the implementation of community policing strategies. The Metro-Life Enhancement Team was formed, an action plan was developed, most of the action plan items were implemented, and the tenants were resurveyed one year latier. 
The evaluation of the project was conducted to assess whether community policing had a measurable effect on public safety. 'The dependent variables were quality of life, fear of crime, and actual crime. Various community policing strategies would be judged to have been successful if reported crime declined, the fear of crime was reduced, and the quality of life improved.

The data show that the project was at least moderately successful. Reported crime declined, fear of crime was reduced, and there were indications that the quality of life was improved. The most striking finding was a $55 \%$ decrease in reported crime during the study period. This study suggests that community policing strategies of partnership, empowerment, problem solving, accountability, and service orientation can be successful. 


\section{ACKNOWLEDGEMENTS}

My gratitude is extended to many people. I want to thank the tenants who taught me to see them as people who deserve a safe place to live. They remained true to their convictions while I grew into the depth of the situation.

I want to thank Dr. Don C. Gibbons, whose guidance and vision showed me the value of determination.

I want to thank Dr. Annette Jolin for extraordinary support and insight.

I want to thank my wife, Sandra L. Herman-Moose, who gave perspective, love and friendship while I completed a cause that has made me a better person. 
TABLE OF CONTENTS

PAGE

ACKNOWLEDGEMENTS .............. . .

iii

LIST OF TABLES .............. viii

LIST OF FIGURES ................ . . ix

CHAPTER

I

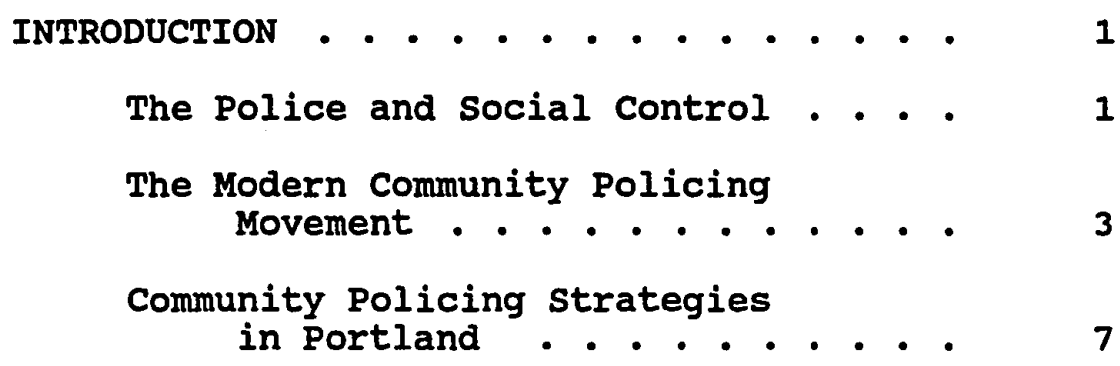

The Police and Social control . . .

The Modern Community Policing Movement . . . . . . . . . 3

Community Policing strategies in Portland

II

POLICING IN AMERICA: THE PAST AND THE

PRESENT . • • . . . . . . . . . . 11

Introduction . . . . . . . . . 11

The Developmental Era . . . . . . 12

The Political Era . . . . . . . 15

The Professional Era . . . . . . 17

The Community-oriented Policing Era . 22

Concluding comments . . . . . . . 27

III THE THEORY AND PRACTICE OF COMMUNITY

POLICING .............. 30

Philosophical Bases of Community Policing .......... 30

Varieties of Community Policing . . . 32 
Community Policing Experiences in

Canada and Japan .. . . . . 42

Community Policing in Canada . . . . 42

Community Policing in Japan . . . . 45

IV POLICING IN PORTLAND: THE PAST AND

THE PRESENT . . . . . . . . . . . . 50

History and Current Patterns . . . 50

$V$ THE IRIS COURT COMMUNITY POLICING

DEMONSTRATION PROJECT • • . . . . . 74

Origins of the Project . . . . . . 74

Selection Rationale . . . . . . . 78

History of Iris Court . . . . . . . 81

Iris Court Eligibility . . . . . . 83

Project Overview . . . . . . . . 84

Project Goals . . . . . . . . . 88

Design, structure, and Leadership
of the Project . . . . . . . 90

Project Action Plan . . . . . . . 94

Action Plan Implementation . . . . 100

Evaluation Design . . . . . . . 103

Process Evaluation . . . . . . . 105

Outcome Evaluation . . . . . . 105

VI PROCESS REVIEW FINDINGS - • • • • • • • • • • 111

Review of the Action Plan . . . . . 111

Chronological Review of Project
Events

Relationship of Project Activities

to Bureau Goals . . . . . . 127 
VII OUTCOME REVIEW FINDINGS . . . • • . . 132

Resident Surveys .. . . . . . . 132

North Precinct Officer's Survey . . . 134

Demographic Characteristics--

Residents ......... 137

Resident Survey . . . . . . . 138

Fear of Crime . . . . . . . . 143

Quality of Life . . . . . . . . 145

Analysis of Crime . . . . . . . 152

Calls-for-service . . . . . . 157

VIII

CONCLUSIONS . . . . . . . . . . . 161

Process ............. . 161

outcome . . . . . . . . . . 162

Recommendations . . . . . . . 164

REFERENCES CITED AND ADDITIONAL LITERATURE . • . . . 167 APPENDICES

A MAP OF IRIS COURT COMPLEX....... .179

B PITRE QUESTIONNAIRE . . . . . . . . . 181

C BENSON MEMOS . . . . . . . . . . . 186

HOUSING AUTHORITY ELIGIBILITY
BROCHURES . . . . . . . . . 189

E IRIS COURT TENANT SURVEY RESULTS:

1990 AND 1991 . . . . . . . . . . 194

F NORTH PRECINCT OFFICER SURVEY RESULTS:

1990 AND 1991 . . . . . . . . . 217

G EVICTIONS . . . . . . . . . . . 234

H TRESPASS LIST . . . . . . . . . . 236

I TRESPASS GENERAL ORDER . . . . . . . . 239 
J SNACK ATTACK NUTRITION PROGRAM . . . . . 258

K IRIS COURT NEWSLETTERS . . . . . . . . . 267

I INTERVIEW TRAINING GUIDELINES . . . . . 276

M PROJECTS BY THE COMMUNITY HEALTH NURSE • • 279 


\section{LIST OF TABLES}

TABLE

PAGE

I Chiefs of Police From 1877 to 1912 . . . 54

II MET steering Committee . . . . . . . 91

III Grant Funds for Iris Court Project . . . 102

IV Eviction Data ............ 116

v Baseline Age Data ......... 138

VI Post Age Data . . . . . . . . . 139

VII Sex and Race Data, Baseline and Post . . 140

VIII Tenant Survey Question \#3, Baseline and Post ............ . . 141

IX Fear of Crime Data, Baseline and Post . . 145

$x$ Quality of Life Data, Baseline and Post . . . . . . . . . . 147

XI Tenant Survey Question \#4, Baseline and Post . . . . . . . . . . 151

XII Reported Crimes for the Iris Court Area, Baseline and Post . . . . . . 153

XIII Reported crimes for the North Precinct, Baseline and Post . . . . . . 155

XIV Reported Crimes for City of Portland, Baseline and Post . . . . . . 156

XV Calls-for-Service (All Types), Iris Court Area . . . . . . . . . 158 


\section{IIST OF FIGURES}

FIGURE

PAGE

1. Evolution of Modern Policing . . . . . . 28

2. Iris Court street Map and the Surrounding Area Used to Collect Crime Data . . 77

3. MET Organizational Chart . . . . . . . 92

4. Demonstration Project organizational Chart .............. 104

5. Number of Reported Crimes for the Iris Court Area . . . . . . . . . 154 


\section{CHAPTER I}

\section{INTRODUCTION}

THE POLICE AND SOCIAL CONTROL

Policing is one of the major, formal devices designed to bring about the regulation and control of behavior in a community. If social disapproval and other informal social processes fail to contain crime, drug abuse, and sociopathic behavior, the police are then expected to provide a main line of defense against deviants and lawbreakers. Parenthetically, the police in modern societies are also charged with the maintenance of public order as well as with the control of crime.

Herein lies a major problem for the police in American society. On the one hand, the United states has historically been characterized by a profound commitment on the part of most citizens to notions of individual freedom. on the other hand, when social disorder reaches intolerable levels, citizens begin to demand that the police employ punitive, intrusive, and sometimes anti-democratic measures (directed, of course, at persons other than themselves).

In recent years, American society has experienced: marked increases in "street violence"; expansion of the illicit drug trade and the use of drugs by citizens; an 
increase in domestic violence, including spousal assault and child abuse; and a growing perception on the part of many persons that crime is out of control. Although some of the evidence on crime levels suggests that "the crime problem" is overblown in the minds of many citizens, it is clear that many Americans have changed the way they live because of their fear of crime (wilson \& Herrnstein, 1985). Americans pay a high price to have the police engage in attempts to solve the problems of social disorder. Given that many citizens have become disenchanted with the crime-control efforts of federal, state, and local governments, many affluent communities have turned to private protection, thus over $\$ 60$ billion is spent yearly in this country on private security and other crime control measures (Moore, Trojanowicz \& Kelling, 1988).

Although very large sums of money have been and are being spent on law enforcement, particularly in the form of police operations in major cities, there is a growing perception, among citizens and among many police leaders, that traditional police tactics aimed at apprehending offenders and/or at deterring potential lawbreakers, are not effective. Many traditional notions of police work, which emphasize a reactive role for the police, heavy utilization of police personnel on random patrolling in police cars, and the like, have come under increasing criticism. In short, calls for new approaches, and in particular, for "community 
policing," have become prominent. Ironically, as will become evident in chapters II and III, these calls for a "new" approach often advocate forms of policing that were once quite common in American society.

THE MODERN COMMUNITY POLICING MOVEMENT

In recent years the police in Portland, Oregon, and other urban centers have found it difficult to provide public safety at acceptable levels and at the same time carry out the manifold other responsibilities with which they are charged. A new direction for policing known as "community policing" has been touted as the solution to this inability to "be all things to all people."

Interestingly, the idea of community policing often involves the proposal that the police should broaden their mission, extending the traditional tasks of law enforcement and order maintenance in ways whereby the police would promote the common good, serve as community social workers as well as law enforcers, and so on. How, then, are the police to become more effective by taking on more work for themselves? The answer put forth by community policing advocates is that the police can both broaden their mandate and become more effective insofar as they engage in cooperative and interactive relationships with the communities they serve. In short, the idea of community policing rests heavily upon assumptions that communities 
have untapped powers to carry out much of the work of law enforcement and order maintenance themselves. For their part, the police are to assume a problem-driven and preventive approach, emphasizing the underlying causal forces associated with crime and disorder (Goldstein, 1977). This new direction for policing began to emerge and take root in the early 1980s throughout the United States and many other countries, including New Zealand, Great Britain, and Canada. Interest in community policing has grown rapidly, and police in many jurisdictions have developed and implemented some form of community policing (or at least something which they have defined as "community policing"). Many of its features have been widely supported by the police and the media. Officers have been freed to engage in proactive crime prevention (Skolnick \& Bayley, 1986), and police operations have become more visible, increasing police accountability to the public in communities where this approach has been tried (Kelling, 1988). Additionally, police operations have been decentralized to meet the needs of various neighborhoods and constituencies. Then, too, citizens have been encouraged to take more initiative in preventing crimes and to become partners with the police, thereby improving relationships between the police and the public. However, while interest in community policing continues to grow rapidly, remarkably little is known about 
what the term means or about the effectiveness of community approaches. The plain fact is that the term has been used to describe aggressive order maintenance, community crime prevention, problem-oriented policing, and a host of other police-community strategies.

Consider the definition of community policing asserted by Trojanowicz and Bucqueroux (1990):

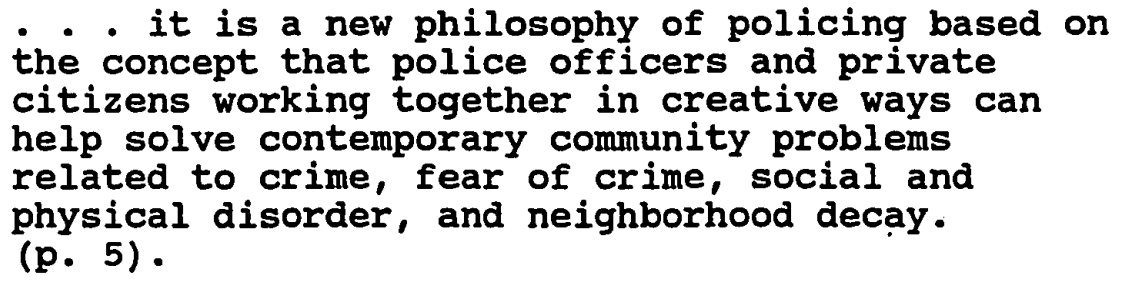

Although this definition may be considered overly broad and virtually meaningless, it demonstrates the general ambiguity about what "community policing" means. This general confusion was echoed in 1988 when the police bureau of Portland, Oregon, set an agency objective of incorporating a philosophy of community policing throughout the organization. The Mayor and city council supported the proposal with formal resolutions and public testimony in 1989. The police bureau adopted the following definition of community policing (Portland Police Bureau, 1990):

Community policing is based on a philosophy which recognizes the interdependence and shared responsibility of the police and community in making Portland a safer, more livable city. It is a method of policing which encourages a partnership that identifies community safety issues, determines resources, and applies innovative strategies designed to create and sustain healthy, vital neighborhoods. Community policing will coordinate with efforts being made 


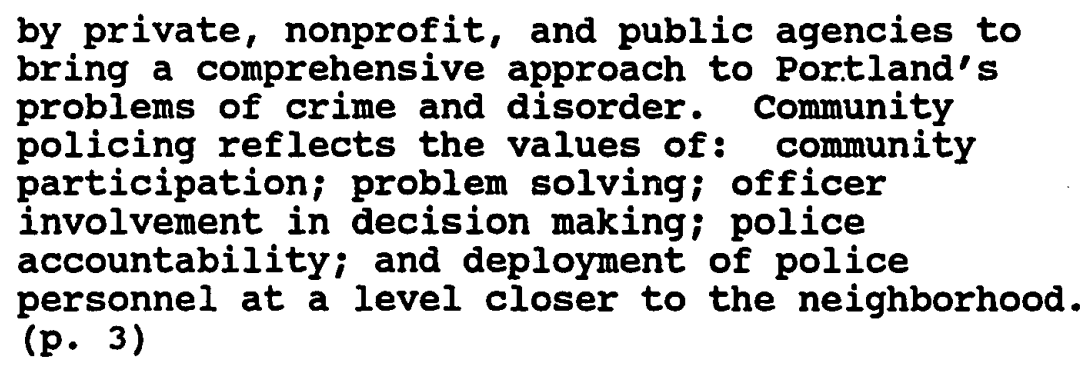

Like the definition given by Trojanowicz and Bucqueroux, this one by the city of Portland is long on broad, ambiguous goals and short on specific indicators of the nature of community policing. Additionally, the Portland statement fails to identify specific implementation programs or strategies. In other words, this is a statement of a very broad set of goals, rather than a "road map" which spells out the routes by which this destination might be reached.

Now, a number of communities have moved beyond the idea of community policing and have embarked on specific programs. For example, there is much to be learned from field experiments in Houston, Newark, and Baltimore, which have endeavored to create interdependence between the police and community citizens. Other "problem-oriented" policing programs have concentrated on controlling drug trafficking through intensive interaction with the community. In Baltimore County, Maryland, a citizen-oriented Police Enforcement program (COPE) was developed in 1982 to fight fear of crime by using a specially trained police unit to interact with citizens (Taft, 1986); while in Newport News, 
Virginia, a Problem-oriented Policing program (POP) shifted the entire department to a style of policing that emphasized problem solving over the traditional reactive models (Eck \& Spelman, 1989). Then, too, a number of police executives and academicians have written extensively about community policing (e.g., Goldstein, Bayley, and skolnick); thus, this is not an idea that is entirely lacking in specificity. At the same time, these examples bear out the contention that the notion of community policing is one which means different things to different persons.

\section{COMMUNITY POLICING STRATEGIES IN PORTLAND}

out of the different approaches to community policing taken by various departments has come a considerable body of descriptive literature reporting mixed results (Greene \& Taylor, 1988; Rosenbaum, 1987; Skogan, 1990; Sparrow, Moore \& Kennedy, 1990). Such results are not surprising in light of the variety of forms community policing has taken and the different interpretations of what constitutes community policing. Because individual jurisdictions have developed their own programs with varying goals, a final judgment about the value of community policing strategies would be premature.

What is most urgently called for at present is: (a) a systematic explication of the philosophy of, and the implementation of, community policing; and (b) additional 
case studies of community policing efforts to date, so that the broad idea of community policing can be fleshed out. This dissertation is a modest step in that direction. Starting first with the case study portion of this research, this research endeavors to determine what success Portland police community policing strategies have had on reported crime, fear of crime, and quality of life for people who reside in and around the Housing Authority of Portland's Iris court housing complex (the site of a Portland Police Bureau community policing initiative). In other words, the study asks: Did community policing have a measurable effect on public safety at Iris court? If community policing strategies are successful, reported crime should drop, fear of crime should be reduced, and the quality of life of residents should improve. If such changes are not observed, those results would suggest that community policing strategies are ineffective at Iris court. Because community policing is principally a philosophy rather than a uniform and detailed program, no manual exists that describes, step-by-step, how to implement it. Accordingly, this study hopefully will provide assistance to the Portland Police Bureau in its continuing efforts to implement community policing, as well as adding to the body of knowledge and experience available to others who are looking for workable solutions to ever-growing public safety problems throughout the world. 
The second major portion of this dissertation consists of an explication of the idea of community policing. More specifically, much attention will be paid throughout this volume to such matters as the origins of community policing notions, the varied forms that this concept has taken, the strengths and weaknesses of community policing strategies, and such issues as the cost-effectiveness of these approaches. Chapter III, in particular, will address these issues.

Before embarking upon the examination either of community policing notions in general or the Iris court project specifically, some detailed attention should be given to the history of policing, particularly in the United states and in its metropolitan centers. This historical account appears in Chapter II and is intended to identify the broader context in which community policing has developed.

As already noted, Chapter III examines the rise of community policing in contemporary America. Chapter IV then turns to a relatively brief account of the historical twists and turns the Portland Police Bureau have taken and also to an account of how this agency arrived at its present commitment to community policing. Chapter $\mathrm{V}$ provides a report on the origins of the Iris court project and upon implementation of the project design. This chapter also provides an informal account of some of the major activities 
and events that occurred during the Iris court project, and Chapter VI offers a process evaluation of that implementation. Chapter VII consists of an outcome evaluation of the project that addresses whether the project achieved its intended effects. Finally, Chapter VIII summarizes the findings of the project evaluation and considers a number of recommendations based upon what was learned from the Iris court project. 
CHAPTER II

POLICING IN AMERICA: THE PAST AND THE PRESENT

\section{INTRODUCTION}

As indicated in chapter $I$; in order to better understand the future of policing in the United States, at least a cursory examination of the history of policing in this nation is required. The historical examination to follow is divided into four sections: the developmental era (precolonial and colonial), the political era (mid-1800s to mid-1900s), the professional era (1930-1980 approximately), and the community policing era (from about 1980 to the present). Clearly, these are not meant to be exact periods, and we need to realize that they overlap in the sense that not every police agency shows an identical history. For example, there were some corrupt, political departments (Spokane, for example) in existence long after professionalization took hold, and similarly, there are currently many departments where community policing has yet to gain a foothold. Much of what follows paints a dismal picture, for, regrettably, American police have often played both a symbolic and a real role as the protectors of the status quo. For much of its history, the American policing institution has had a well-deserved reputation as a 
thoroughly disreputable one. The history of American policing is one of ineptitude, partisan politics and widespread corruption (Gibbons, 1992).

THE DEVELOPMENTAL ERA

In 17 th and 18th century colonial America, functionaries such as the sheriff and the constable, as well as "watch and ward" operations, dominated police work. The sheriff and constable systems were law enforcement styles derived from England, while the "watch and ward" arrangement was one in which unpaid citizens engaged in voluntaristic forms of policing. Quite naturally, American colonists in the 17th and 18th centuries brought to America the law enforcement structures with which they were familiar in Europe. The sheriff had many duties, but collecting taxes was a primary concern. City constables and the night watch volunteers performed a variety of tasks. The night watch reported fires, maintained street lamps, made arrests and walked the rounds (Monkkonen, 1981). Further, the constable was generally responsible for dealing with both civil and criminal matters. Most sheriffs, constables, and watch volunteers were motivated less by ideals of public service than by pecuniary interests. Persons who did not wish to perform watch duty paid others to stand in for them, while sheriffs and constables were paid on a fee system, that is, they levied fees against jailed prisoners or in other ways 
raised their wages from private citizens. This type of business mentality led to widespread inequality and injustice. Most services were provided according to one's ability to pay. The end result was misconduct and abuse by "police" officials. In addition, law enforcement was reactive; in other words, the police responded only after being hailed by citizens.

These early forms of policing probably made a fair amount of sense in colonial and post-colonial America, when the country was sparsely populated, most cities were exceedingly small by present-day standards, and crime problems were apparently much less severe. Parenthetically, anachronistic versions of the sheriff and constable systems still exist in many places in the united states. In Texas, for example, untrained citizens are still elected by public vote as constables, while in many relatively rural counties in the United States, county sheriffs function very much as they did decades ago.

This colonial model existed until the 1830 s and 1840s, when major riots in 1834 in both Boston and New York served as trigger incidents for changes in policing. When situations in these cities seemed to be uncontrollable through the existing sheriff, constable and watch forms, there were two other models available. One was the slave patrol system employed in the south to control and recapture 
slaves, while the other was the London Metropolitan Police model (Walker, 1977).

Obviously, the slave catcher system was not generally adopted in the United States; instead, most large American communities turned to the British policing system. By the mid-1800s, most larger American cities had established unified, full-time, paid, and partially trained police agencies. Boston established a full-time police department in 1837, followed by New York in 1844 and Philadelphia in 1854 .

In addition to paid, full-time police workers replacing sheriffs, constables, and volunteers, other features of British policing styles grew up in the United states. For one, American police agencies adopted many of the preventive patrol strategies of the London police in which the presence of patrolmen walking their assigned beats was expected to deter actual and potential offenders. However, while this operational strategy was a shared one, the administrative makeup of American police agencies differed from the English arrangement. The American police were decentralized from the national government and came under the control of local, city governments.

Although the urban riots of the early 1800 s were trigger incidents that led to the creation of full-time, paid police, other factors were involved as well. The transition from a local to a national marketing system, 
changes associated with the early Industrial Revolution that created the "boom or bust" cycle for workers, the swelling of eastern cities with mutually hostile immigrants from Ireland, Germany and native hinterlands, and the growing complexity of city living made the new system of police necessary. The police gave directions, unsnarled traffic, returned lost children, escorted drunks, provided for homeless drifters and often provided soup kitchens and many other services in mid-19th century America.

\section{THE POLITICAL ERA}

During most of the 19th century, the police were captives of corrupt city governments and political machines (Walker, 1977). When a new political group was elected, the practice was one of "out with the old, in with the new"-officers beholden to the defeated political party were fired, and new ones were hired. The 19th century patrolman was basically a political operative rather than a public servant.

Indeed, it was often difficult to distinguish "the cops" from "the robbers," in that the police protected gambling houses, prostitutes and saloons, and collaborated in other ways with lawbreakers. Police officers often acted as "bag men," collecting graft from vice operations to be delivered to the political higher-ups who reaped the spoils from endemic corruption. Policemen also frequently operated 
as individual entrepreneurs in the petty forms of graft. Police corruption was also internal to the police, as assignments and promotions were determined by bribes and friendships.

The end of the 19th and the beginning of the 20th centuries witnessed reform efforts led by a group commonly known as the Progressives. Gibbons (1979) has offered this description of the Progressive movement:
Who were the advocates of progressivism? They were middle-class farm owners, storekeepers, clergymen, lawyers, doctors, and others who stood between the small band of extraordinarily wealthy industrialists and financiers and the teeming masses of the working poor. Although these solid and industrious middle-class workers were enjoying relative affluence, they were displeased with the economic trends they saw occurring in the United states. The progressive movement drew into its ranks prohibitionists, advocates of women's rights, small businessmen who were incensed about competition from the giant trusts, and an assortment of other individuals who saw advantages to themselves in progressive proposals - . progressives advocated rehabilitation of criminals, assistance for the poor, and humane treatment for the insane . . . progressives supported programs for creating healthy work conditions, decent housing, public ownership of utilities, and scientific administration of cities, as well as efforts to deal positively with social problems. (pp. 20-21)

Not surprisingly, these advocates of social reform and good government zeroed in on political corruption and the sins of the police as one of their targets. However, they had little success in reforming police departments. While administrative boards were created to manage the police, civil service was introduced to control hiring and promotion 
policies; and much conversation about change was heard, but little real change took place in the workings of the police.

THE PROFESSIONAL ERA

The Progressives' efforts at police and government reform were followed by internal police efforts at reform and professionalism. These differed from the earlier efforts of the Progressives because the leadership and initiative came from within the command ranks of the police. This movement was founded by a few lonely reformers who advocated that the police adopt a professional model. The leaders of this movement were primarily Richard sylvester, August Vollmer, 0. W. Wilson, and william Parker. The movement generally covered the period from approximately 1930 to 1980. Richard Sylvester called for the adoption of technological innovations such as the patrol car, the two-way radio and the telephone. August vollmer called for educated and trained police officers. Vollmer is known for his pioneering work in using forensic science in solving crimes and his active recruitment of college students for police work. 0 . W. Wilson endeavored to identify some principles of efficient police organization and is best known for his classic textbook, Police Administration, which discussed the organizational structure needed to provide professional, economical police services. During his reign, William Parker, former chief of the Los Angeles Police 
Department, used public relations campaigns and planning to make Los Angeles a model for reform; he stressed planning, efficiency, in-depth training and close working relationships between the citizens and police officers. (For additional details on Parker see, 0 . W. Wilson's Parker on Police, 1957).

Although there were some important steps taken toward police professionalization in the 1930-1960 period, the events of the 1960s overshadowed everything that came before this decade. Police in America were confronted with a marked increase in crime, a volatile civil rights movement, widespread anti-Vietnam War sentiments, and race riots in the cities. Discussion of the details of these various incidents would take us too far afield, but one point is clear: As in earlier periods of strife, the federal government reacted by calling for studies and investigations, most notable of which were President Lyndon Johnson's 1967 National Advisory Commission on Civil Disorders (commonly known as the Kerner Commission) and the President's Commission on Law Enforcement and the Administration of Justice. The Kerner Commission identified institutionalized police racism as an underlying cause of the many riots of the 1960s, but it should be noted that it also cited unemployment, discrimination in jobs, unfair housing practices, and inadequate social services as other contributing problems. The police were criticized for 
brutality, harassment, inadequate supervision, improper training and poor community relations. similar messages had been brought forth by reformers Vollmer, Wilson and Parker. The recommendations of the President's Commission on Law Enforcement and the Administration of Justice led to the creation, by Congress, of the Law Enforcement Assistance Administration (LEAA). Federal aid administered by LEAA funded research on such topics as patrol deployment methods, officer selection, community relations programs and the evaluation of policing techniques. This influx of money and research helped move the police institution toward greater professionalism.

Given the problems with police and community relations during this period, this funding and research was welcome and overdue. One result of this new attention to the police was the realization that the idea of professionalism contained important flaws (Walker, 1985). In particular, the emphasis on professionalization had resulted in an insular police subculture that had isolated the police from the community. While professionalization had doubtless had the positive effect of removing most police departments from the corruption and politicization of an earlier period, the price paid was often estrangement of the police from the citizens and communities that they were supposed to serve. This police-citizen estrangement was fueled by such practices as the heavy emphasis in most urban police 
departments upon random patrols by officers in one-person or two-person patrol cars. Police-citizen tensions were also sometimes fueled by aggressive patrol tactics and other ingredients of the "professional style."

Police-citizen tensions became even more pronounced in the late 1960s and early 1970s, as aggrieved minority group members, disaffected young persons, the poor, and anti-war activists all began to criticize "the system" (i.e., American society) and began to agitate for major social changes. Not infrequently, these felt grievances were reacted to with hostility by those who were manning "the system." The latter often called upon the police to "restore order," with the result that police-citizen confrontations were altogether too familiar in the 1970 s and to a lesser extent in the decade that followed.

The police were not insensitive to the chorus of criticism directed at them. In a number of cases their first response took the form of efforts to "cool out" their critics through such devices as police-community relations departments. These can be said to be efforts at "cooling out" the public, because they usually endeavored to persuade citizens to change their views of the police but rarely involved real efforts by the police to respond to criticisms.

Throughout the nation, police departments inaugurated specialized public relations programs involving such tactics 
as sending speakers to business luncheons and efforts to sell the police to the public. Police leaders had begun to realize that the police need to interact with all the different groups within a community, whereas earlier public relations efforts had concentrated on improving the police image among middle-class adults and youth. Although the st. Louis Metropolitan Police Department is credited with establishing the first permanent community relations unit in 1957 (Brown, 1971), O. W. Wilson's 1977 police administration textbook recommended that all large police departments establish a formal community relations unit. Even so, getting the police to see community relations as a necessary part of police work proved to be a difficult task. The basic limitation of the public relations approach was that nearly all of the departments with community relations units assigned this task to special units, leaving the remainder of the organization to take its ordinary course, doing "police work." Accordingly, public relations bureaus were essentially cosmetic rather than real innovations. In many ways these units simply reflected more general societal patterns. Schools had the Parent-Teachers Associations (PTA), but the superintendent and principal made all the important decisions; and hospitals had doctors who made all of the crucial decisions while volunteers merely kept patients entertained and comfortable. 
These observations about community relations ventures do not mean that no progress was made in police agencies in the period between 1960 and 1980. As police agencies moved through this period, many of them used technological advances in innovative ways; thus, computer-aided dispatch led to increased dependence on automobiles and the 911 telephone system. Also, the police continued to stress professionalism and became convinced that with increased budgets they could handle the ever increasing crime problem.

THE COMMUNITY-ORIENTED POLICING ERA

In the past decade or so, the myth that professional police can handle all law-enforcement problems came face to face with continued urban unrest and the urban fiscal crisis. The populations of larger cities, largely comprised of minorities with little money and little hope, began to experience increasing conflict with the police because of the latter's mandate to maintain the status quo. These conflicts further reduced what little communication and cooperation that had existed between the police and the citizens they were attempting to control. Police departments employed policies and procedures that had negative effects on Blacks, lower-class youth and the poor. Saturation patrols and close surveillance with traffic stops and searches may have been workable tactics to control street crime, but young people, minorities and those who 
drove unconventional or dilapidated vehicles or dressed unconventionally saw their interests threatened by this increased surveillance. The police had little or no positive contact, input or interaction with these groups. As a result, police-community relations units began to recognize the need to concentrate on the segments of the community that were neglected by the earlier public relations and community-relations programs (Wilson, 1985). The community policing perspective had roots in the views of Sir Robert Peel of the London Metropolitan Police who thought that the police could and should be "the people's police," that is, an agency that is responsive to the public it serves. The changes from police public relations, to police-community relations, to community-police relations, to community-oriented policing all reflect a return to one of Peels' principles which asserted:

To maintain at all times a relationship with the public that gives reality to the historic tradition that the police are the public and that the public are the police; the police being only members of the public who are paid to give full-time attention to duties which are incumbent on every citizen in the interests of community welfare and existence. (Mayhall, 1985, p. 425).

The transition from public relations to community relations to community-oriented policing reflects several common themes that focus on citizen involvement and crime prevention. Storefront centers that serve as small police precincts in public places, such as stores and reception 
centers, are examples of efforts to increase accessibility. The Rumor Control Network is another program designed to connect the police and community, with the goal of sharing, gathering and clarifying information during a crisis. still another program is Neighborhood Watch which encourages area residents to identify local problems while watching out for each other, thus becoming an extension of police patrols. When home, they scrutinize strangers who are in the neighborhood. They also, inform others when they expect to be away from home. The police also encourage site hardening and property identification, meeting with residents to facilitate the installation of locks and the marking of possessions with visible, easily recognizable numbers (most often social security numbers or state driver license numbers). These crime prevention efforts gave residents a role in public safety.

The evaluations of crime prevention activities and strategies suggest that while the range of crime prevention tactics has expanded, many of these efforts are ineffective; and we are still unable to make major inroads against crime (Rosenbaum, 1987). Nevertheless, these crime prevention efforts emphasized the idea that citizens have a role in police matters so that watching started to replace walling and wariness as the central role for citizens (Sherman, 1983). This increased role for citizens is the foundation block of community policing. 
The concept of community policing can be clarified by looking further at its evolution. During the 1940s, Joseph D. Lohman, a sociology lecturer at the University of Chicago, began to teach courses in police minority-group relations to park police officers. During the same period, Gordon Allport, a Harvard professor, was training the Boston police in similar subjects. Allport's courses included concern with crime causation and social disorder, as well as racial, religious and ethnic conflict between the police and the community (Radelet \& Reed, 1986).

Bridge building between the police and the community was enhanced during the mid-1950s with the work of the National Institute on Police and Community Relations. As Radelet and Reed (1986) report, the goals and objectives of the institute were:

1. To encourage police-citizen partnership in the cause of crime prevention.

2. To foster and improve communication and mutual understanding between the police and the total community.

3. To promote interprofessional approaches to the solution of community problems and to stress the principle that the administration of justice is a total community responsibility.

4. To enhance cooperation among the police, prosecution, the courts and corrections.

5. To assist police and other community leaders to achieve an understanding of the nature and causes of complex problems in people-to-people relations and especially to improve police-minority group relations. 
6. To strengthen implementation of equal protection under the law for all persons. (p. 17)

These were ambitious goals. The National Institute on Police and Community Relations was conducted each year from 1955 to 1969 , as a combined effort of Michigan state University and the National Conference on Christians and Jews 。

As indicated earlier, by the mid-1960s many American urban centers were in turmoil, and the police were seen as the trigger in many incidents of riot and disorder. These events led some police leaders to search for better programs of police and community relations. One of these was called team policing, which evolved as an alternative to the classic bureaucratic model (Angell, 1971; Brown, 1976). The team policing concept involved many of the strategies currently associated with community policing. For example, it stressed the need for police familiarity with the community so as to create a sense of attachment or ownership (Sherman, Milton \& Kelly, 1973). Other themes common to both team policing and community policing are decentralized decision-making and demonstration projects. Overall, however, team policing did not prove to be successful (Schwartz \& Clarren, 1977). 
CONCLUDING COMMENTS

The evolution of modern policing from the 1940 s looks something like Figure 1. Clearly, this was not a "pure" evolution, and developmental experiences varied from agency to agency. Also, it is important to note that this was an evolution, not a revolution. Innovations in police strategies were necessary because police work takes place in an ever-changing environment which includes social, technological, moral and political influences. In this changing environment, police agencies should not be surprised that their strategies must also change. Police work has been impacted by civil rights legislation, the interpretation of existing laws and new laws, new communication and travel methods, changing patterns of work and play, new diseases such as AIDS, new elected officials, changes in financial resources, and many other forces. By the mid-1980s, progressive police leaders and academicians had begun to clearly articulate the importance of power sharing by the police and the community to solve problems (Brown, 1985). Past efforts to distance the police from communities in the name of "professionalism" had proven unsuccessful in solving community crime problems. Although the movement to professionalism had been successful in creating an apolitical and on the whole incorruptible workforce, the isolation had also proven costly. 


\section{PUBLIC RELATIONS}

\section{$\downarrow$}

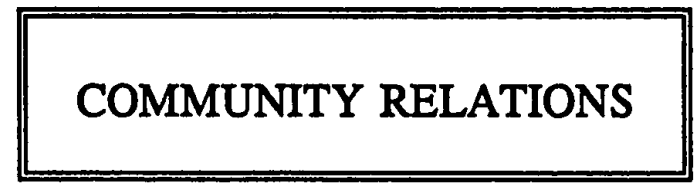

$\downarrow$

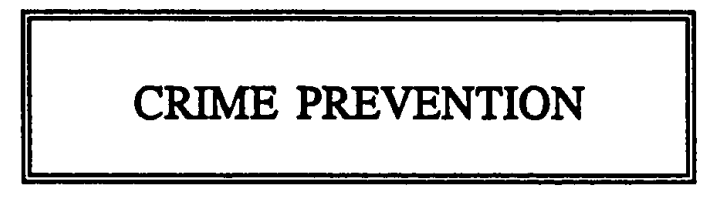

$\downarrow$

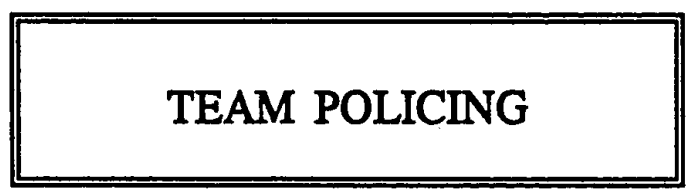

$\downarrow$

\section{COMMUNITY POLICING}

Fiqure 1. Evolution of modern policing. 
Nevertheless, as agencies and individuals began to hear about community policing, the question often arose: "What is community policing?" Manning (1988) has suggested that community policing:

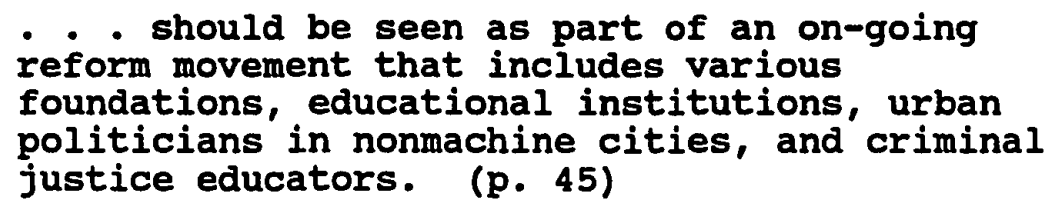

In other words, there was no exact plan, strategy or road

map that identified the compass of community policing.

The following chapter examines the concepts behind

community policing. In addition, it contrasts community

policing and problem-oriented policing while also reviewing

the influence of community policing in Canada and Japan on

the American experience. 


\section{CHAPTER III}

\section{THE THEORY AND PRACTICE OF COMMUNITY POLICING}

\section{PHILOSOPHICAL BASES OF COMMUNITY POLICING}

The review of American police history in Chapter II suggested that it is important that the police and community work together to provide public safety and security if the American crime problem is to be reduced. Neither the police or the community alone can solve crime and public safety issues. And, if the two are at odds with each other, these problems only become worse. The historical record of the police is one of corruption, insensitivity to minority populations, brutality, isolation and political independence. Further, even though most urban police departments became relatively professionalized some decades ago, the reform known as community policing faces barriers, some major ones having to do with resistance from within the departments.

Although it is difficult to give a precise definition of community policing, the following are often mentioned as its common elements: increased police-citizen accessibility, the use of problem-oriented approaches, aggressive and/or punitive order maintenance strategies that require the police to intervene without a specific complaint, increased 
contact between the police and community organizations, strengthening of community cohesion and the sponsoring of community crime prevention activities (Goldstein, 1977). According to Skolnick and Bayley (1986) the four elements of community policing are: police-community reciprocity, real decentralization of command, reorientation of patrol, and civilianization. Peter Manning (1984) asserts that the concept of community policing has four meanings: ideological, that is, restoration of the sense of community found at an earlier time when communities were more unified and the police received help and support from citizens; programmatic, that is, community policing involves a series of programs to restore police closeness with the community, although these may have nothing to do with crime; pragmatic, that is, the police want to show themselves as less bureaucratic and impersonal and more crime focused and centralized; and organizational, which means emphasis on area or team policing and broad and intensive communication with community groups. Community policing can also be defined as "thoughtful, service-oriented policing aimed at enhancing the quality of life..." (Sparrow et al., 1990). When the above themes are reviewed and combined with the definitions offered by Trojanowicz and Bucqueroux, along with the Portland Police Bureau concepts referred to in Chapter I, two common themes emerge: one, the establishment of strong links between police and communities to coordinate 
law enforcement with other services affecting the neighborhood's quality of life; and two, the increased ability of law enforcement to identify, analyze and respond to community problems in systematic ways. These activities are manifested in the field experiments in Houston, Newark and Baltimore (Pate \& Annan, 1989) which have shown that closer ties between the police and citizens raise the level of citizen satisfaction with police services, improve the quality of community life, and reduce the levels of fear of crime.

\section{VARIETIES OF COMMUNITY POLICING}

As already noted, community policing has been structured and implemented in various ways. There is no single program definition or model that has been followed, and no guide to assign staff and resources to assure implementation of the concept. As a result, community policing has taken many forms with very different strategies and policies ranging from: designated community specialists; special units within the department, such as community crime prevention units or neighborhood response teams; special operations units that target specific areas for community policing; or a total organization philosophy applied citywide.

In Madison, Wisconsin, a department-wide community policing effort, initially concentrating on an experimental 
police district, was implemented. A team management concept was established to test the effect of decentralization in this district that had storefront police stations and permanently assigned officers. The city of Houston used neighborhood storefronts and patrol-initiated community activities in an experimental community policing effort referred to as Neighborhood-oriented Policing that featured Directed Area Response Teams (DART). In New York City, a long-range community policing effort was initiated in a single-model precinct, replacing an earlier community policing effort that in 1984 was labeled the Community Patrol officer Program (C-POP). The C-POP effort assigned community patrol officer teams to the 75 city precincts. These teams did community policing while the other precinct personnel did "police work."

The cities of Newark, Flint, Edmonton, and Oakland all initiated foot-patrol programs to fight crime and reduce the fear of crime. For example, the Oakland program focused on the downtown central business district with foot patrol, mounted patrol, small vehicle patrols and a Report Incidents Directly (RID) program. The overall program focus was on street crime, because these activities were fear inspiring and kept law-abiding people away from the central business district.

The current variability among community policing programs is also reflected in the national initiative called 
"Operation Weed and seed," a comprehensive and integrated multi-agency approach to eliminate violent crime, gang activity, drug use, drug trafficking and related crime from targeted high-crime neighborhoods. It is intended to provide a safe environment, free of crime, in which law-abiding citizens can live, work and raise their families. "Operation Weed and seed" was introduced by President Bush's administration and was based on the premise that a partnership of federal, state, and local governments, community organizations and citizens, and businesses and nonprofit organizations is essential for creating safer urban neighborhoods.

The "Weed and seed" program sees community policing as the bridge between "weeding" (law enforcement) and "seeding" (neighborhood revitalization). The federal program expected community policing to ensure that reduced levels of drug use, trafficking and related crime, which result from the "weed" activities, are maintained. Community policing was also expected to reduce fear in the community so that economic development and related social services could take root. Under "Operation Weed and seed," neighborhood reclamation and restoration began with the development of community law enforcement where community services could grow. Such programs were expected to help improve living conditions, enhance home security procedures, allow for low-cost physical improvements, and develop long-term 
efforts to renovate and maintain housing, as well as to provide educational, economic, social, recreational, and other vital opportunities.

Another variation of the community policing theme is problem-oriented policing (Eck \& Spelman, 1989; Goldstein, 1990). In general, problem-oriented policing involves an active police force that identifies persistent problems and their underlying causes and finds solutions to these problems (Goldstein, 1990). Although police work often calls for immediate reactions to criminal incidents, research has suggested that incident-driven policing does not have a substantial impact on many of the problems that citizens want the police to solve.

Problem-oriented policing is based on the thesis that the police need to attack underlying problems that give rise to incidents that consume patrol time, that they must rely on the expertise and creativity of line officers to study problems carefully and develop innovative solutions, and that the police must work closely with the public to assure that they are addressing the latter's needs. Problem-oriented policing consists of a scientific process that has four stages: scanning, or problem detection and identification; analysis, or learning the problem's causes and consequences; response, or designing and implementing a solution; and assessment, or evaluation of the effectiveness of the solution. This systematic inquiry process is an 
often used training tool and is referred to as "the SARA model."

The National Institute of Justice tested the effectiveness of this problem-solving approach in Newport News, Virginia (Eck \& Spelman, 1989). The work by Eck and spelman indicated that these efforts were an effective way to solve problems. Instead of relying on broad, law-related problem categories such as robbery or burglary, officers were encouraged to use the scanning phase to group individual related incidents that came to their attention as problems and then to define those problems in more precise and, therefore, more useful terms. For instance, an incident that might be classified as an isolated robbery may actually be one of a series of prostitution "trick rolls" that can be solved by having a judge put an area restriction clause onto the probation conditions of a convicted prostitute. The prostitute can subsequently be arrested for trespass and probation violation any time he or she enters the area that has proven to be good "turf" for "trick rolls." In the analysis phase, officers working on a problem collect information from all available resources and use these data to illuminate the underlying nature of the problem, suggest its causes, and point to a variety of options for its resolution. In the response phase, officers work with citizens, businesses, public and private agencies to tailor a program to address the problem. Solutions may 
go well beyond traditional criminal justice system remedies to include other community agencies or organizations. In the assessment phase, all involved parties evaluate the impact of their efforts to see if the targeted problems were actually solved.

Although it would be tempting to conclude that the distinction between community policing and problem-oriented policing is merely an academic one, the two strategies are often seen as different. At the root of the distinction is the question of whether problem-oriented policing can be practiced outside of a community policing focus. The Portland, Oregon, experience focuses on community policing and includes problem solving as one of six organizational goals. The Portland police also have the goals of partnership, empowerment, accountability, service orientation and project management. In Portland the entire agency is being moved toward community policing, not problem-oriented policing.

In San Diego, the police implemented problem-oriented policing at the patrol officer level with minimal direction from supervisors and command level staff. Officers were encouraged to identify problems on their beats, then craft and implement responses with guidance from supervisors using department resources. The nature and structure of problem-oriented policing in San Diego is largely defined by officers' practices in the field. In 1989, 50 
problem-oriented policing cases were formally opened by 21 patrol officers; by November 1991, department log sheets listed 474 active problem-oriented policing cases being handled by 378 officers across six patrol divisions. ${ }^{1}$ In other words, in San Diego, problem-oriented policing became an established police program that is diffused throughout the department, although it is not a "community policing" approach.

The debate about community policing and problem-oriented policing continues, and both strategies may be needed to properly address a jurisdictions' needs and problems. Problem-oriented policing that fails to pay attention to and involve citizens in solutions risks continued police isolation and unrealistic expectations, because it can foster the view that the police can handle the problem by themselves, and citizens have no need to become involved. Although problem-oriented policing can be very effective in targeted areas, community policing can use the problem-solving tool in improved delivery of police services, improved police-community relations and mutual resolution of identifiable problems.

Support for community policing also recognizes that many cities around the world have reached a critical point

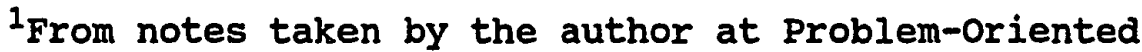
Policing Conference, San Diego, California, 1992.
} 
in their response to social unrest and crime; and because the world is changing rapidly, they can no longer adhere to traditional forms and reactions. Large-scale migrations are bringing people of different races, cultures and languages into closer contact with each other, making enormous demands on everyone's tolerance. Concurrently, these cities and their police agencies are faced with declining economies, overburdened social and public services, widening class divisions, more broken families than at any earlier time in history, increasing populations, violent youth gangs and failing infrastructures.

It can be argued that anything short of total community policing risks creation of the perception that the police are detached from the community's problems and that they are too remote and independent to be able to effectively deal with the citizens' problems. Community policing establishes an image of helping instead of controlling, because it broadens the definition of an agency's function. Community policing is proactive, decentralized and includes order maintenance, conflict resolution, problem solving and a strong commitment to crime prevention, reducing crime, disorder, and fear of crime (Sparrow et al., 1990). Community policing appears to have considerable crime control potential, because it recognizes that communities, cultures and societies are diverse. It allows the police to tailor tactics to the specific needs 
and make-up of the communities they serve (Davis, 1985). The Portland experience with community policing appears to have changed public perceptions of the police and has created a more positive picture of police work.

Several cautionary points are in order: community policing must confront the communities' need for traditional, reactive policing. Someone has to respond to crime scenes, take notes, collect evidence, capture perpetrators, and bring suspects to trial. This researcher's experiences have paralleled the observations of Weatheritt (1987), who noted that community residents do not prefer one policing method (traditional versus community policing) over another. They want to be involved with and provide input and direction to the police, but they still expect rapid responses to their calls for police service whether the issue is a criminal or civil one. Accordingly, the task is to combine the best of both styles. The police need personnel who can understand and implement departmental procedures, local, state, and federal laws, mediation styles and techniques, and defensive tactics, while also demonstrating improved interpersonal and social skills as well as an understanding of society's social problems and acceptable solutions (Fink \& Sealy, 1974; Goldstein, 1977; Johnson, Misner \& Brown, 1981; Wilson, 1968). Community policing requires that the police will be interested in crime causation as well as with capture, 
punishment and prevention. And again, this focus must be tailored to the community being served (Alpert \& Dunham, 1989; Gabor \& Low, 1973). Perhaps this idea has never been more clearly stated than in Sir Robert Peel's Principle which declared:

To maintain at all times a relationship with the public that gives reality to the historic tradition that the police are the public and that the public are the police . . . (Mayhall, 1985 , p. 425)

Community policing also involves the problem of deciding how the police are to determine exactly what the community wants. If the police are to be responsive under community policing, a considerable degree of consensus on the definition of serious crime is required. To many people, serious crime means violence, open drug dealing, burglary to our homes, and kindred offenses, while to others, serious crime may mean "red lining" in the real estate industry, industrial pollution that will destroy the ozone layer, or tax evasion. The question is, how do the police resolve conflicting definitions of "the crime problem," and what if no identifiable "community" exists? Finally, community policing is time-consuming and labor-intensive. We must ask whether the community can afford the cost of enough police personnel to assure that each officer can spend the necessary time with each citizen and problem while still meeting his or her other 
responsibilities, including emergency response and follow-up investigations.

COMMUNITY POLICING EXPERIENCES IN CANADA AND JAPAN

While drafting the Metropolitan Police Act of 1829, Sir Robert Peel spoke of a police-community relationship that is commonly implied in contemporary discussions of community policing. The idea of community policing is not unique to the United States. Police agencies throughout America have implemented various strategies of community policing, but so too have various agencies in other nations. Police systems in Canada and Japan are complex, but the section below briefly reviews the experiences from community policing in those countries and the resulting lessons to be learned for policing in the United States.

\section{COMMUNITY POLICING IN CANADA}

According to Chris Murphy (1988):

Community policing has replaced professional crime control policing as the dominant ideology and organizational model of progressive policing in Canada. (p. 77)

Chris Braiden, Superintendent of the Edmonton, Alberta, Canada Police Service regards community policing as a 
"revolution of the slow evolution of regular police work."1 In Kathy Koller's Working the Beat (1990) Braiden was quoted as saying, "Who else were we intending to police? People don't say they are going fishing for fish, fishing says it all" (p. 60). In other words, Braiden meant that the term community policing is redundant.

Although many community policing strategies in Canada mirror those in the United States, there are differences, the main one being the willingness of Canadian citizens and police officers to accept the idea of community policing instead of being forced to do so. This contrast is clearly seen in the example of the Los Angles Police Department. The March 3, 1991, incident commonly referred to as the Rodney King Case, where Mr. King was beaten by police officers following a vehicle chase (with the scene captured on videotape and broadcast worldwide), resulted in the call for the firing of Chief Gates, the appointment of a new Chief of Police and the implementation of community policing (Christopher, 1991). More generally, calls for reforms in local police agencies have been commonplace in the United states, beginning with the rise of full-time departments and continuing to the present. In contrast, Canadian agencies have received little criticism and are generally

\footnotetext{
${ }^{1}$ From notes taken by the author during address by $\mathbf{M}$. C. Braiden, Keynote Speaker, Problem-oriented Policing Conference, San Diego, California, 1992.
} 
well-supported and popular with their citizens (Murphy, 1988). Many of the top agencies in Canada have worked closely with United states research agencies such as the Police Executive Research Forum (PERF) and the National Institute of Justice (NIJ) and have enthusiastically adopted successful police innovations. In short, many Canadian law enforcement officials have aggressively sought to change to community policing.

The issues that have arisen from community policing in Canada are very similar to those in the United States. For example, Canadian police are also confronted with questions about how a "community" should be defined, the role of the community in police decision making, and whether community policing is moving the police into areas of advocacy that should be left to private citizens.

Overall, community policing has been well-accepted in Canada. This style brings police service to the consumers and lets the latter get to know "their cop." The police enlist the support of people who live and work in local areas, and relationships of trust are built (Koller, 1990). The Canadian model in which the police are part of the community and work to involve the community in solving community problems is worthy of emulation. 


\section{COMMUNITY POLICING IN JAPAN}

Over the past decade, many Americans have demonstrated an infatuation with Japan and the Japanese, particularly their management styles, electronic products, and automobiles. As Japanese industry and business gradually overtook their American counterparts, studies comparing differences between Western and Japanese business organizations and activities have become commonplace. It is perhaps not surprising, then, that Japan would also be looked to for guidance from its police strategies and styles, particularly given that nation's apparently low crime rates. Clearly, the American criminal justice system, including the police, may be in need of an infusion of new ideas, given that crime here continues at high levels and also that more persons are imprisoned per capita in the United States in any other nation, including the former Soviet Union and South Africa. And, despite "get tough" and "war on drugs" policies, the fight against illegal drugs appears to be an uphill battle, at best, and a losing one, at worst.

Three major differences are often cited between crime in the United States and Japan (Becker, 1983):

A. Differences in criminal justice systems, including more training in Japan than U.S., higher esprit de corps between Japanese police officers, more efficient courts in Japan, and the Japanese ban on handguns. 
B. Differences in public cooperation, involving higher participation of witnesses and victims in Japan than the United States. Becker illustrates this public cooperation by recounting when during the 1970's, Japanese filmmakers glorified Japanese gangsters, there was public pressure to stop this portrayal. Presently feature films almost always show gangsters as pathetic, disreputable characters, which is particularly interesting, in light of the prominence and visibility of Yakuza gangsters in Japan. This type of "mind policing" does not exist in the United States.

C. Differences in social structure, that is Japanese society stresses interdependence, responsibility and honor. Becker clearly infers that Japan's low crime rate is not based on technology, but on sociological characteristics. (p. 271) [Also see Braithwaite, 1989.]

These appear to be real differences between the two nations, with Japan receiving most of the positive ratings. Nevertheless, there is reason to wonder how successful community policing might be in the United States compared to Japan. Is it possible that the community policing model may be more difficult to implement in America? This question still awaits a conclusive answer.

The most visible and most publicized community policing strategy in Japan is the Koban, or police box system, which serves as a neighborhood service center. Kobans are located at strategic locations throughout a city and have been in use in Japan since 1874 when the first police bureau was created (Allen-Bond, 1984). Kobans are staffed round-the-clock and foster familiarity and communication of police with citizens (Bayley, 1991). The Kobans police engage in counseling, crime prevention, 
surveys, and networking with other government agencies.

This Koban activity is similar to problem-oriented policing in the United States (Goldstein, 1990). David Bayley (1991) describes the difference between the Japanese Koban and the United states style of policing in the following terms:

- . police penetration of the community in Japan is more routine and personal than in the United states and it is more active in ways unrelated to law enforcement. Deployment in Kobans forces police officers in Japan to play a role in the community as known persons, not like American police officers, who are seen as anonymous faces flickering by behind a facade of steel . . . An American policeman is like a fireman--he responds when he must. A Japanese policeman is like a postman--he has a daily round of low-key activities that relate him to the lives of the people among whom he works. (p. 86)

Clearly, both Japanese and American police administrators have recognized the need for community involvement in police programs. Still, the Japanese situation differs from the United states in ways that likely prevent the direct transfer of all Japanese practices to this country. For example, Japanese cultural attitudes about drinking alcohol, gambling and prostitution make these "events of pleasure, not an insidious social force" (Bayley, 1991). In addition, the cultural homogeneity of Japanese attitudes means that the police are not in conflict with the community they serve. Because the police do not attempt to legislate morality, the number of conflicts with citizens at large is reduced. In addition, Japanese culture enables the Japanese criminal justice system to depend on "reintegrative 
shaming," in which lawbreakers are first held accountable for their crimes, then drawn back into a supportive community (Braithwaite, 1989). While Japanese miscreants are urged to accept responsibility for their offenses, individual failure is also seen as group failure. The entire family is shamed by inappropriate activity, but the culture requires that it take the errant member back into the fold and work to reintegrate him or her into the family and culture.

The Japanese police have learned the importance of listening to and interacting with the community while many American police organizations have not. The Japanese model needs to be studied and where possible, implemented in the United states. The special efforts devoted to listening and interacting are commendable and should be emulated when possible. For example, the Japanese make annual visits to every home in a Koban patrol area and send out Koban newsletters as part of the effort to reduce alienation that often results from the social pressures of modern society. Like Canadians, the Japanese police seek to be a part of the community and to involve it in solving community problems.

Having briefly reviewed the theory of community policing, it is now time to turn to Portland's venture into this new approach. Chapter IV reviews the history of policing in Portland and singles out the events that led to 
the commitment to community policing as the preferred policing style for the city. 
CHAPTER IV

POLICING IN PORTLAND: THE PAST AND THE PRESENT

\section{HISTORY AND CURRENT PATTERNS}

Although there is no universally accepted definition of community policing, in 1989 the city of Portland commissioners and police officials adopted community policing as municipal policy. To gain an understanding of current events and why the Portland police and the city Council settled upon community policing as the proper policing philosophy, we need to review the history of the bureau.

While East Coast cities such as New York and Boston were forming police agencies in the 1780s, Portland did not become an incorporated city in the oregon Territory until 1851 :

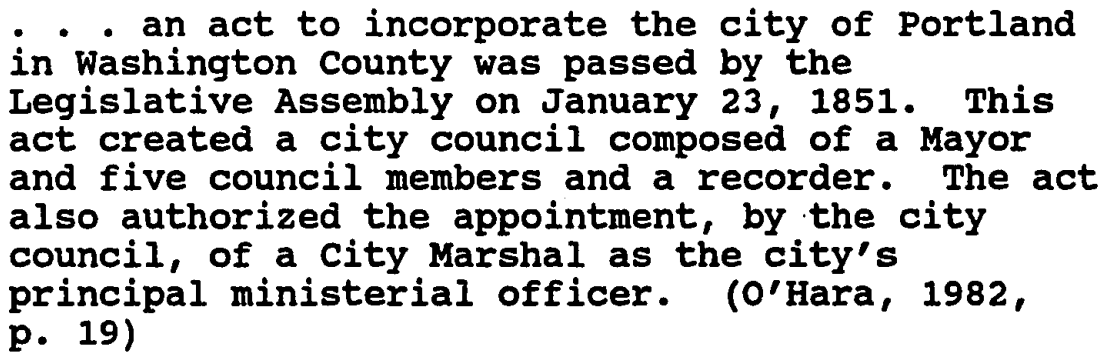

Similar to earlier sheriff and constable systems in other parts of America, the Portland Marshal system paid the staff 
through fees collected for specific services (i.e., arrests, court appearances, and maintaining street lamps).

Although the 1851 Marshal system under Portland's first Marshal, Hiram Wilber, seemed to be functioning well, in 1853 the legislature repealed the Portland City Charter and changed the system of government to a Mayor and nine council members. This change also provided for an elected Marshal, and in 1853 william B. Gooms became Portland's first elected Marshal.

The New York City police first received police uniforms in 1853 but it was not until 1862 that population growth and other conditions in Portland developed to a point where the City Council requested the Marshal to design and display an emblem or device to identify the "official character" of the Marshal's force.

After existing on partisan politics and the Marshal system for almost 20 years, on september 12, 1870, the City Council created Portland's first full-time, fully paid police force and named the then city Marshal, Phillip Saunders, Chief of Police. Chief Saunders set the department size at eight officers (one chief of Police, one Lieutenant, and six patrolmen), submitted a guidebook pertaining to the behavior and conduct of officers, and submitted detailed plans for a police headquarters at second and oak streets. 
The record indicates that chief Saunder's performance was generally acceptable, but partisan politics were the order of the day. As a result, political power was demonstrated in October 1870 when the Oregon State Legislature passed Senate Bill 34, amending the 1864 Portland City Charter and providing for a Board of Police Commissioners. The bill also gave the Board of Police Commissioners complete control of Portland's police functions, including hiring, firing, and discipline, except Portland had to pay all costs. In addition, the Governor was given authority to appoint the Board. As a result, the Board was made up of Democrats even though Portland's City Council at the time was Republican-controlled. Shortly after this bill took effect, James H. Lappeus was appointed Chief of Police, along with a staff of seven (one Captain and six patrolmen). Two examples of the power of politics were the City of Portland having to pay for police services although controlled at the state level, and the fact that only two members of Chief Lappeus's staff had any police experience or qualifications other than being loyal Democrats. Perhaps the most noted part of this confusion of 1870 is that reporters of Portland history have often identified two persons as the first Chief of Police.

since political patronage determined the selection of police officers, the police force reflected political considerations. From 1870 until 1912, the Board of Police 
Commissioners controlled a very corrupt police department. The city Council regained the authority to appoint Police Chiefs in 1875, only to see state politicians give this authority back to the Governor in 1885. The many changes of Chiefs of Police from 1870-1912 did little to reduce the confusion. Table I presents a list of Portland's various Chiefs of Police from 1877 to 1912. John Clark's reign as Chief of Police saw a City of Portland Charter amendment that changed the form of city government from a ward system to the Commission-Council form. The police department became the Police Bureau of the Department of Public Safety. Chief Clark oversaw the consolidation of the City of St. Johns with Portland in 1915 and the conversion of the st. John's City Hall into a fire station and police precinct. clark was followed by one of the most notable and longest tenured Chiefs of Police in Portland's history, Leon V. Jenkins.

Jenkins served from November 8, 1919, to June 30, 1933. Mayor George Baker remained in office throughout Jenkins's term of service. Chief Jenkins was able to significantly reduce the political influence on the police, and his tenure was noted for many technological changes in Portland police work. Some of the notable improvements included: organization of a Traffic Division; organization of an Auto Theft Division; reorganization of police records; revamping of identification and fingerprinting; creation of 
TABLE I

CHIEFS OF POLICE FROM 1877 TO 1912

\begin{tabular}{lr}
\hline \multicolumn{1}{c}{ Name } & Date of Appointment \\
\hline Lucerne Besser & June 18, 1877 \\
James Lappeus & October 30, 1879 \\
William Watkins & July 1, 1883 \\
Samuel B. Parris & December 2, 1885 \\
Charles H. Hunt & November 12, 1892 \\
John W. Minto & August 1, 1894 \\
D.W. Robertson & October 5, 1896 \\
John Meyers & March 11, 1897 \\
Patrick Barry & June 9, 1897 \\
Michael J. Clohessy & July 8, 1897 \\
Daniel M. McLoughlin & July 30, 1897 \\
Charles H. Hunt & January 23, 1903 \\
Charles Gritzmacher & July 15, 1905 \\
A. M. Cox & July 2, 1909 \\
E. A. Slover & July 1, 1911 \\
John Clark & July 1, 1913 \\
\hline
\end{tabular}

Portland's first Police Academy; formation of the Portland Vigilance Police, which evolved into the Sunshine Division (the Sunshine Boys did fundraising and volunteer work to feed the needy); and pioneering the use of the radio in police work. Jenkins also served as chairman of the International Chief's of Police Uniform Crime Reporting 
Committee. The stability and innovation he introduced helped the Portland Police to be viewed as a professional organization. After his first stint as Chief of Police, Jenkins served as Inspector from 1933 to 1947 prior to becoming Chief of Police again (O'Hara, 1982). His accomplishments notwithstanding, Jenkins was not without his critics. Maccoll (1979) has noted that:

As early as the fall of 1920 , the oregon Journal had accused the police department of entering into a conspiracy with the bootleggers . . . On other occasions the police department was accused of "making a monkey out of the mayor and a goat out of chief Jenkins by willfully disobeying regulations and providing tips on raids." Regardless of what was charged, however, prohibition created a no-win contest for the city and police officials. It bred police corruption and produced a number of wealthy crooks. (p. 276)

Chief Jenkins was succeeded by Burton Lawson on July 1, 1933. Chief Lawson was succeeded by Harry M. Niles on December 1, 1934, who earlier had been instrumental in assisting former Chief Jenkins with the reorganization of police records. That earlier work had led to his being loaned to the federal government to organize a central records system for the federal prohibition enforcement agency. He was so successful that he was assigned to reorganize a regional bureau in San Francisco and from there, went to Santa Barbara, California, to reorganize the police department. In 1931 he became the Deputy Superintendent of the newly formed Oregon state Police, where he organized its record-keeping system (O'Hara, 1982). 
After appointment as Portland's Police Chief in 1934, Chief Niles spent 12 years (1934-1946) striving to make the Portland Police Bureau more professional. He was also a public figure who stressed public relations strategies to improve communication between the police and the citizens of Portland. However, when lumped with the mayoral administrations of Joseph K. Carson, Jr. (1933-1941) and Earl Riley (1941-1949), his tour of duty has been labeled as "business as usual," during which the police were directly responsible to the Mayor's office. According to Maccoll (1979), "Mediocrity and indifference at the top produced equally mediocre and indifferent enforcement of the law, particularly in matters related to vice" (p. 609).

Chief Niles's ill health forced his retirement on June 30, 1946, but Leon Jenkins was reappointed on July 1 , 1946, and continued the efforts to move the agency toward professionalism. However, by summer of 1947 , critics of the police convinced the city council to order an evaluation report from August Vollmer, the retired chief of Police of Berkeley, California. According to August Vollmer (cited in Maccoll, 1979) ". . . for at least the last seven years Portland's police bureau had been overcostly, underproductive, poorly organized, inadequately supervised and underpaid" (p. 84).

Chief Jenkins was replaced by James Fleming on January 6,1948 . Close on the heels of that appointment, a 
February 1948 City Club report (cited in Maccoll, 1979)

indicated that open prostitution and vice activity were rampant in the city. (The City Club is a group of Portland civic activists who gather information and study issues that affect the city of Portland). "The City Club report . . clearly revealed how the existence of illegal activities, condoned by the police and higher authorities, corrupted the whole law enforcement process" (MacColl, 1979, p. 610). According to Joseph Unis (1981), "The Vollmer Report and the city club report . . . changed public attitudes toward the police and the mayoral race in Portland in 1948" (p. 59). According to Unis, the City Club report identified eight major problems or findings:

1. Syndicates controlled gambling completely and were exacting tribute from gamblers--slot machine owners paid $\$ 50$ a month per machine, dice table owners were paying $\$ 50$, and so on. . .

2. Mayor Earl Riley had failed to assume direction of the police department in his duties, he failed to consider the police department's importance in the scheme of city government, and he was inadequate in his supervision. . .

3. Payoffs had placed police authorities under obligation to criminal elements and police immunity had led to many opportunities for criminal activity to flourish. Personnel had been shifted in the police department to make it easier for gamblers, bootleggers and pimps to operate. . .

4. Portland had become a dumping ground for dope, bootleg activities, prostitution and the like. . .

5. State and local officials were actively participating in and protecting horse and dog gambling and the state liquor monopoly. . . . 
6. During the period from 1943 to 1945, one group controlled all gambling, bootlegging and prostitution in the city, and in fact, its position was aided and abetted and defended by the police department; illegal and legal confiscations of equipment of opposition operators were routine during those years. . .

7. The police department sent out orders as to when vice establishments could operate, when they should be closed. Beat patrolmen exacted their own small payoffs, ranging from $\$ 10$ to $\$ 50$ a month from those operations. . .

8. When the police did raid syndicate joints, such raids were a farce. The proprietors were informed ahead of time, equipment was moved out and the only persons arrested were bums off the street (City Club Bulletin, February 20, 1948). . . (Unis, 1981, p. 60)

The Vollmer and City club reports raised serious questions about the administrations of Jenkins and Niles. The evidence of overwhelming corruption surely calls into question the claims of Purdy (1947) that "Harry Niles rose from the ranks and had the respect of all who knew him. Chief Leon $V$. Jenkins also rose from the ranks and has been a good Chief for Portland" (p. 50).

The Vollmer and City club reports apparently doomed the re-election of Mayor Riley and opened the way for the election of Mayor Dorothy McCullough Lee. According to Maccoll (1979), Lee ran a law and order campaign. According to Unis (1981):

- . conventional sources show that Lee did clean up the police department. She appointed a new Chief of Police, Charles Pray (January 1, 1949), a professional policeman and retired state police executive. She brought into involvement in police affairs a professional staff including Donald McNamara, later chief under Mayor Terry 
Schrunk. She raised the salaries of policemen. She ordered the padlocking of various vice operations throughout the city. (p. 62)

Unis (1981) also noted that "Dorothy Lee's cleanup efforts changed Portland's reputation and altered its self image" (p. 66).

Chief Pray was succeeded by Donald I. McNamara on May 1, 1951. Pray had been the first superintendent of the Oregon state Police which the legislature had created in 1931. Mayor Lee had persuaded Pray to come out of retirement to assume command of the Portland police and to identify officers who would be qualified for future leadership. Donald McNamara had been one of those nominated leaders.

Mayor Lee lost her 1952 reelection attempt to Fred Peterson, who on January 1, 1953, replaced McNamara with Jim Purcell. The Portland vice problem reemerged during Purcell's tenure. According to Unis (1981):

During the reign of Mayor Fred Peterson (1952-56), afterhours bootleg and gambling establishments flourished in Portland with little action from either the Portland Police or the OLCC enforcement people. The Attorney General's office became aware of more than mere tolerance of liquor violations. Gifts ranging from cases of liquor to trips to the Kentucky Derby were reportedly accepted by oLCC enforcement people. The entire North Precinct of the Portland Police as well as others were being paid off, reported Thornton in his history (Thornton, Oregon state Archives, 1959). (Unis, 1981, p. 86)

Chief Purcell had managed during an era that would become known as the vice probe of 1954-58. This probe was 
highlighted by the U.S. Senate select Committee on Improper Activities in the Labor or Management Field hearings in Portland. The Committee was chaired by John L. McCellan; Senators Irving Ivers, John F. Kennedy, Sam J. Irvin, Pat McNamara, Joseph R. McCarthy, Karl Mundy, and Barry Goldwater were other committee members, and the Committee council was Robert Kennedy.

Chief Purcell was indicted by a Grand Jury in the fall of 1956 on charges of incompetence, delinquency and malfeasance although no trial resulted. Purcell's tenure ended when Terry Schrunk was elected Mayor in 1957, and William J. Hilbruner was appointed Chief of Police on January 1, 1957.

Hilbruner died while Chief of Police and was succeeded by David H. Johnson on November 21, 1960. He, in turn, was succeeded by former Chief McNamara on July 21, 1964, and the latter provided ten years of stability, serving for the remainder of Mayor Schrunk's tenure. Chief McNamara created the Police Community Relations Division in May of 1968, about which the 1971 Police Bureau Annual Report provided the following information:

The Police Community Relations Division was formed in May, 1968, when it became apparent that there was a vital need for this type of service. They have been very active in many community programs and have established rapport with minority groups in the Portland area.

Funds for the Portland Model Cities Community Relations Project are made available through the U.S. Department of Justice, the Department of 
Housing and Urban Development and the City of Portland.

Personnel for the project consist of a Lieutenant as Commander, ten sworn police officers, a community service officer supervisor, fifteen community service officers, two of whom are women, a sergeant as night shift commander, and a secretary. The number of community service officers was expanded from ten to fifteen during 1971, due to the availability of special federal funds. The unit is located at 3807 N.E. Union Avenue, phone 282-4524, and is operational from 9 am to lam, seven days per week.

The project operates a number of programs which are intended to make the uniformed officers task an easier one by improving mutual understanding between the citizen and the police. We are attempting to facilitate improved police service by developing a closer working relationship between citizens and the Police Bureau. . . . (p. 12)

The account offered above indicates that although the Portland police had a storied and dismal history of corruption and vice, it was not until the Black communities in Portland, Los Angeles (1965 Watts Riot), and many other cities started to confront the establishment that Portland police officials started to talk about "improving mutual understanding between the citizens and the police." Apparently the mistrust and dishonesty from the earlier years was accepted by the community, and the police bureau had no obligation to communicate and work with local citizens. Another portion of the 1971 annual report (Portland Police Bureau, 1971) showed two Black men dressed in blazers standing beside a police car with the following caption: "The units' [Community Relations Division] top 
priority for 1972 is the recruitment of minority citizens to the Portland Police Bureau" (p. 13).

The 1972 Annual Report covered almost the exact same information about the Community Relations Division. The last paragraph read: "As part of their regular duties, personnel cover situations which have a potential for violence or friction, with the object of lessening tension" (p. 13). This statement suggests that during this period of police corruption, the police had created a modus vivendi with those groups involved in criminal activity and that there was no conflict or tension with other citizens. Consequently, there was no need for special units or efforts to communicate with the community. Police-community relations operations were designed to make the uniformed officer's job easier. No vehicle for citizen input into police operations was involved, nor was any message involved about making the community a better place in which to live.

The historical nemesis of the Portland Police Buraau, vice, was briefly mentioned as a problem in the 1972 Annual Report (Portland Police Bureau, 1972) because of "Skin Trade Shops," live sex acts at local theaters, street prostitution, pornography and gambling, all of which are difficult to repress because of legislation passed in 1971 . There was no mention of corruption and no mention of a need to work with the community. 
Chief McNamara was succeeded by Bruce $R$. Baker on January 15, 1974. A nationwide search had been conducted in 1973 to find a replacement for MoNamara. Many qualified men applied for the position both from within the bureau and from across the nation. After a four-month screening process, Mayor Goldschmidt announced his choice, and on January 15, 1974, Baker, then chief in Berkeley, California, assumed command of the Bureau. There were many rumors and stories about the process and the impact of this selection of an "outsider" on the bureau

Chief Baker led the Bureau into computerized records, innovative in-service training, increased crime prevention, a total revision of the Manual of Rules and Procedures, the establishment of fourteen broad goals and eighty related sub-objectives which served as the basis for long-range planning for four years. The efforts of Baker appeared to reflect: the support of a progressive young Mayor; his own experiences in Berkeley, where August Vollmer's influence dominated; and the funding and research provided in the 1970 s by the Law Enforcement Assistance Administration (LEAA) •

While Baker introduced a number of innovative programs, his stands against corruption and untruthfulness were the clearest signs of what he attempted to accomplish with the police bureau. Baker was apparently the first Portland Chief of Police to insist that untruthfulness be 
grounds for termination, and he may not have been convinced that the tradition of corruption had been truly broken. Three events highlighted Baker's tenure. Early on there was the episode, often referred to as the Liming case, involving a local security guard and police "groupie" who was stealing items from stores and then selling them as "one-time good deals" to Portland police officers. Baker acted quickly and firmly against those involved: Those who confessed were disciplined and those who were untruthful were terminated.

The second incident occurred some time into Chief Baker's seven-year reign. On March 12, 1981, two Portland police officers threw dead opossums onto the public sidewalk on Union Avenue in front of a Black-owned and Black-frequented restaurant known as the Burger Barn. It had been a location of much aggressive police activity, was seen by the police as a hangout for Blacks involved in criminal activity, and had caused much frustration for members of the Portland Police Bureau. At the time of the incident, the restaurant was open for business and several customers were inside. The officers involved were terminated, and the Black community thought Baker had acted correctly; internally, however, police officers held marches and took a vote of no confidence against the chief of Police. An arbitrator heard the case, and on August 7, 1981, the officers were reinstated. 
Almost concurrent with the Burger Barn incident was an investigation of a Drug Unit scandal that resulted in the resignation of several narcotics officers and the conviction of one of them for felony crimes. Although the police bureau reacted properly, the investigation took over a year and when viewed as an indication of management, the agency appeared to be out of control.

It seems a fair judgement that chief Baker had little impact on community relations and played no part in the eventual acceptance of community policing. What was critical was: the development by Mayor Goldschmidt of the Office of Neighborhood Associations; the employment of civilian, non-police bureau employees as crime prevention specialists; and the development of neighborhood associations with a voice in city Hall. The neighborhood association concept allowed Portland citizens an opportunity to organize along neighborhood and community lines. In addition, these associations allowed citizen access to city government and began to create a sense of participation that had not existed in the past. Some saw this move as an organized campaign device for the very popular Mayor, but whatever the merits of that claim, the fact is that the groups started to become an autonomous force in the city. These active neighborhood groups have since served as the foundation for many successful political campaigns and have exerted a great deal of influence on city politics. The 
sense of involvement and participation has proven to be the cornerstone in the implementation of community policing in Portland during the early 1990s.

Chief Baker was succeeded on June 1, 1981, by

Ronald R. Still who brought a "law and order," "spit and polish" style to the Portland Police Bureau. Whereas Baker had allowed officers to wear contemporary hairstyles, still created a short hairstyle expectation as part of the message that "if you look sloppy, then your work will be sloppy." In short, still's emphasis was on accountability and correctness, not to the community, but rather to the paramilitary police organization model.

However, the scandals during the Baker administration had raised questions about police accountability and citizen involvement. Those incidents had caused members of the public to ask: "Who would police the police?" (Jolin \& Gibbons, 1984). As a result, the Task Force on Police Internal Affairs had been appointed by City Council member Charles Jordan who was in charge of the police bureau during the last months of the Baker administration.

When the Task Force issued its report in July 1981, Chief Still, Mayor Ivancie and the Portland Police Union were strongly opposed to the recommendation that called for a "citizen advisory committee" to be involved in the review of police misconduct. Still and Ivancie opted not to form the committee, but three council members passed an ordinance 
creating it. These three council members joined eight appointed citizens to form the Police Internal Investigations Audit Committee (PIIAC). For a time, it appeared that new life might be breathed into citizen involvement in the Portland Police Bureau. However, the Police Union was successful in putting the issue on the general election ballot. Following months of public sloganeering and argumentation, in November 1982 the voters approved the oversight committee. Chief still, Mayor Ivancie and the Police Union saw this committee as a barrier to effective policing, but "the architects of the audit committee saw its central mission to be one of bringing about increased citizen confidence in the police department" (Jolin \& Gibbons, 1984, p. 319). This thinking and citizen involvement was new to Portland's police-community relations environment.

The committee's contribution to improving police-community relations is to show the police where their procedures obstruct the detection of misconduct and implicitly reward misconduct by favoring officers over citizens. (Jolin \& Gibbons, 1984, p. 323)

J. E. "Bud" Clark had been elected Mayor in 1984, and it quickly became clear that his views on policing were very different from those of chief still. clark had challenged the closed government style of Ivancie and wanted a more open, neighborhood-oriented police bureau. still was succeeded by Gary M. Haynes on January 4, 1985, who in turn 
was shortly replaced by Portland's first female Chief of Police, Penny Harrington, on January 24, 1985.

At least at the outset, Harrington proved to be a very popular and visible Chief of Police. She was invited to do studio appearances on such national television shows as "the Johnny Carson Show" and "Good Morning America." But she was plagued by budget cuts (in fiscal year 1884-85, the city laid off 60 sworn police officers) and a questionable reorganization of the Drug Unit. These events were followed by an investigation into the activities of her husband, a Portland police officer, and an outside review of her management style. Harrington was ultimately terminated by the Mayor and was succeeded by an Acting Chief of Police, Robert M. Tobin, on June 2, 1986.

Considerable turbulence and leadership turnover followed the Harrington period. Tobin was succeeded by James T. Davis on August 20, 1986. Davis focused on the shortage of personnel within the organization and had a rocky relationship with Mayor clark. He was succeeded by Richard D. Walker on April 7, 1987. Walker had been a Deputy Chief of Police who had retired in January of 1985. Walker recognized the need for and importance of working with others within the criminal justice system. He also saw the need to work with various community members in the city. Walker formed the Community Policing Division and worked with future Chief Thomas Potter to develop the plan for the 
implementation of community policing within the bureau. The Still era had denied citizen access to the police bureau, while Mayor clark had been elected in part because of his determination to open up the bureau. However, he had been too busy hiring and firing chiefs of Police during the first few years of his administration to make much headway on his real goal. Walker seemed to understand that as the chief of Police he was expected to use his knowledge of the bureau and his law enforcement experience to implement the will of the Mayor. Since Clark, a local neighborhood tavern owner who ran his campaign as an outsider determined to open city Hall and other bureaucracies (including the police) to the regular citizens of Portland, it was only a matter of time before he would find a chief who would understand and pursue his goal.

A common problem surrounding Mayor clark and community policing is that he was not clear on how to articulate his goal until he heard former Houston Police Chief Lee P. Brown discuss community-oriented policing at a conference. Brown was the former sheriff of Multnomah county, the county in which Portland is located. While leading the Multnomah County Sheriff's office, he had implemented team policing, which has often been seen as the forerunner of what is now termed community policing. Brown was later able to implement neighborhood-oriented policing in Houston. He is often cited as a leader in the law enforcement move toward 
community policing and has written many journal articles about community policing. Clark found Brown very credible. After hearing him explain community policing, clark was much clearer in his ability to articulate what he desired of the Portland Police Bureau.

clark also drew upon new information obtained by then Captain Thomas Potter from a trip to Japan by police executives from several American cities sponsored by the Eisenhower Foundation, the purpose of which was to explore community policing in America and Japan. This trip led to follow-up and technical support from the Eisenhower Foundation for all agencies willing to make an effort to implement community policing. It should be noted that Lee Brown was also a member of this work group.

Potter hammered out the "how to" Five-Year Transition Plan, and Chief Walker provided some continuity at the top for the police agency that had experienced six chief executives since 1980. The community was now primed for its chance at increased participation with their police.

Two other factors that influenced the movement toward community policing in Portland were also at work. First, the Citizen's Crime Commission, a citizen group backed by the Chamber of Commerce, ordered an organizational study of the Portland Police Bureau on September 11, 1989. The Citizen's Crime Commission is seen as a very powerful, influential group within the city. There was an expectation 
that the recommendations in the study would be reviewed by leaders in city government and implemented within the police bureau. This study was conducted by the Institute for Law and Justice at a cost of over $\$ 100,000$. It was completed in November 1989, and the final report published in January 1990 showed that the population and the geographic area of Portland had increased over the previous ten years, but police bureau staffing had declined over the previous five years (Institute for Law and Justice, 1990). During those same five years, crime had increased. The report contained many positive comments about community policing and the need for this style of law enforcement within the city. The report also recognized that community policing provided a "coherent, comprehensive, long-range strategy" that had never been a part of the police process (Institute for Law and Justice, 1990). This positive view certainly paralleled the perspective of the Mayor.

A second factor was that jail overcrowding was severe, both within the city and the state of oregon. The Portland Police Bureau uses the jail services provided by the Multnomah County Sheriff and a shortage of available jail space had a negative impact on the policing efforts of the bureau. Persons convicted of crimes were being released, not because they had served their sentences, but rather to make room for more serious offenders. For example, a matrix system was used to decide when to let a burglar out in order 
to lock up a rapist. Currently, whenever Portland police officers capture someone in a stolen car, they check to see if the person has any outstanding warrants, then determine if that person has been photographed and fingerprinted. If the individual has no outstanding warrants and has been photographed and fingerprinted, he or she is given a citation to appear in court at a later date. If the person has not been fingerprinted and photographed, he or she is taken in for that process and then released with a citation. If the individual has an outstanding warrant, he or she remains in jail until bail is obtained (ten percent of warrant total) or until seen by a judge. This condition caused frustration among police officers and citizens, and it also demonstrated that simply arresting people would not be acceptable. Community policing offered hope to this situation because it included the expectation that repeat arrests could be reduced by solving problems by other means. Chief Walker was succeeded by Thomas Potter on November 19,1990 . Potter worked diligently to implement community policing until his retirement on June 30, 1993.

This chapter has provided a much-compressed history of policing in Portland. We have seen how the idea of community policing has emerged. Chapter $\mathrm{V}$ examines a specific project effort that was one major community policing initiative in the city, called the Iris court Community Policing Demonstration Project. This project will 
be described and evaluated in order to reduce some of the vagueness and mystery about community policing. The information will also cover many of the community policing concepts that were discussed in Chapter III. 


\section{CHAPTER V}

\section{THE IRIS COURT COMMUNITY POLICING DEMONSTRATION PROJECT}

\section{ORIGINS OF THE PROJECT}

On July 5, 1989, the Portland City Council passed a resolution outlining a community approach to policing that would better align police resources with the public safety concerns of neighborhoods and businesses. A second resolution was passed on october 24,1989 , defining organizational issues and expected outcomes for a mandated police bureau implementation of community policing over a five-year period. On January 31,1990 , the final draft of the Portland Police Bureau Community Policing Transition Plan (Portland Police Bureau, 1990) was submitted to the City Council for approval.

One of the first-year goals in this plan, approved unanimously by the council, was to "have three or more demonstration projects implemented. It was anticipated that each of the three precincts will host one or more demonstration projects" (Portland Police Bureau, 1990, p. 22). To this end, the police bureau had formed a Demonstration Project selection Subcommittee during the fall of 1989. The subcommittee had sent out requests for input to neighborhood associations, business associations, church 
groups, all Portland police officers, local social service agencies, organized interest groups such as the Black United Front and the Urban League, and all individuals and organizations that had participated in any of the previously held public community policing forums or work groups. During November 1989, thirty-five submissions were received by the subcommittee. These included twenty-five community submissions, nine police bureau submissions and one submission with no name or organization attached. These submissions were evaluated, and seven community-identified problem areas were selected for potential demonstration projects using the following criteria (Portland Police Bureau, 1990):

Community Acceptance--within an area of the city with residential and business acceptance of, and participation in the demonstration project.

Visibility--a tangible, concrete and high profile project.

Validity--objective measurability of expected outcomes. It was expected that the demonstration projects will allow the Police Bureau to not only experiment with and evaluate techniques, but also provide a window for the Bureau and the community to get a glimpse of how community policing works. (p. 22).

On March 19, 1990, Chief Walker held a meeting to discuss and further evaluate the list of the seven possible demonstration projects. At this time the projects were narrowed to three possibilities:

1. Transient, homelessness: "garden-variety" crimes being committed by this population group. 
2. Problem parks within the precincts.

3. Drug houses within certain patrol areas of North Precinct.

At this meeting Chief Walker and Captain Potter stressed the need for each of the three police bureau's precincts-Central, East, and North--to have a demonstration project located within their boundaries. After continued discussion, the representatives from Central and East Precincts accepted projects that concerned the transient and homelessness crime problem. The North Precinct representative narrowed the drug house problem to an apartment complex (Iris court) and accepted it as a demonstration project. Precise time frames were not agreed upon at this meeting.

The Iris Court Community Policing Demonstration Project had the following geographic boundaries: North Killingsworth street (north), North Vancouver Avenue (east), North Webster Street (south), and North Commercial Avenue (west). Iris court is the common name for an 108-unit public housing complex owned and operated by the Housing Authority of Portland (see Appendix A). Other names for the units within the Iris court complex are Sumner court, Royal Rose Court and Royal Rose Annex. All of these are geographically conterminous and hereafter will be referred to as Iris court. Iris court is within the boundary of the Portland Police Bureau's North Precinct. Figure 2 shows the 


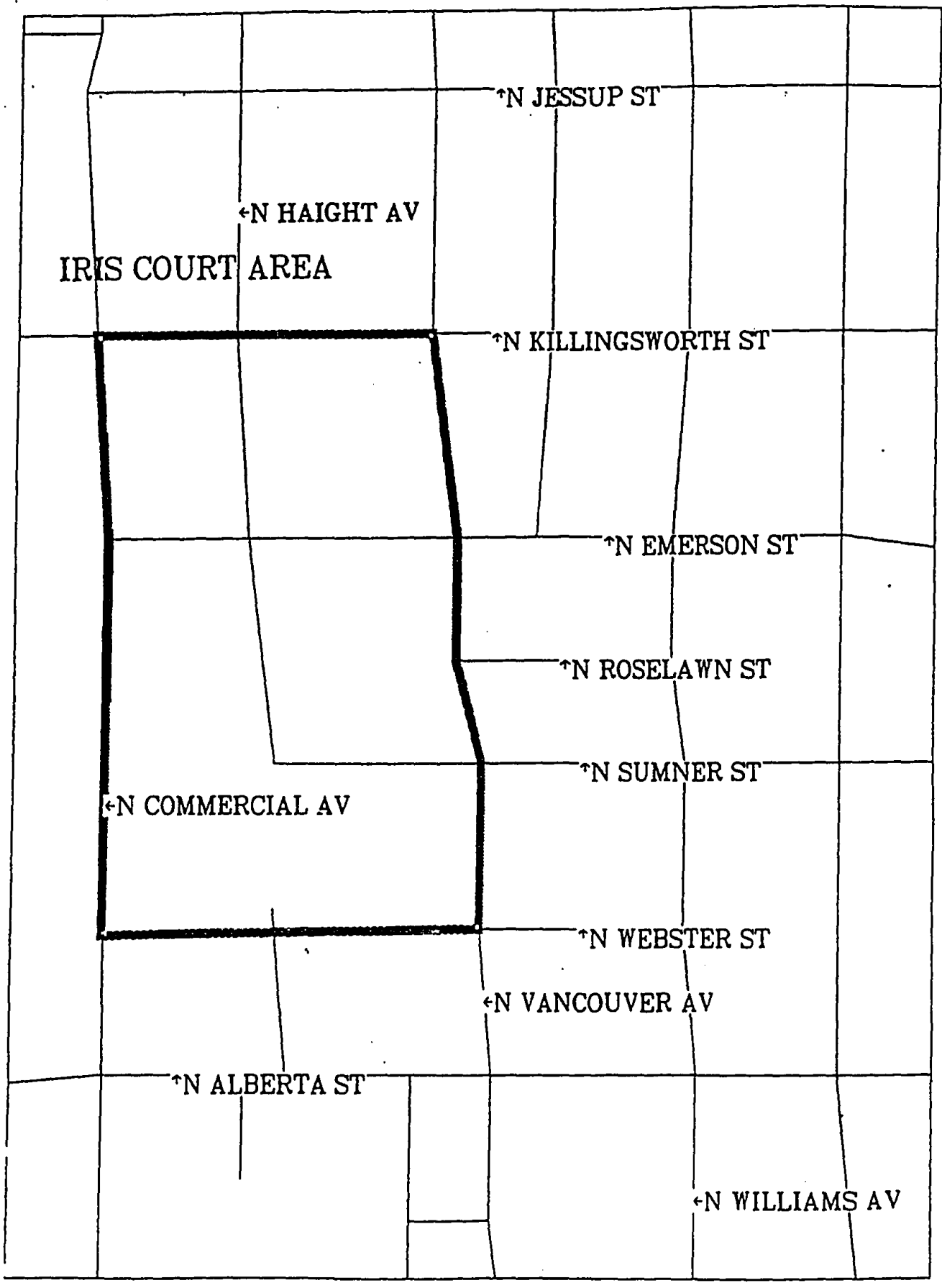
Figure 2. Iris court street map and the surrounding area
used to collect crime data. 
area in which crime data was gathered during the study period.

\section{SELECTION RATIONALE}

\section{A Community Policing Problem Identification}

Questionnaire completed by Judi Pitre, Director of Housing Management, Housing Authority of Portland, assisted in the selection of Iris Court (see Appendix B). The questionnaire data indicated that the residents felt powerlessness to help themselves in an environment that had blatant drug trafficking and an increasing incidence of gang violence. More importantly, the residents indicated a desire to work with the Portland Police Bureau to seek solutions that involved Crime Prevention Through Environmental Design and the expansion of some existing community partnerships. The observations of some Portland police officers also were influential in the selection of Iris court as a demonstration project. North Precinct officers reported that the complex (Iris Court) suffered from highly visible drug trafficking within apartments, on the street, and from within parked cars. The Housing Authority staff and the police officers were aware of unauthorized visitors illegally occupying apartments. Some of these persons were invited guests or relatives of residents and some occupied the units through coercion and intimidation. The climate fostering open violence was clearly demonstrated in the 
October 4, 1989, assault of two Portland police officers on routine patrol. Following the assault, a large, hostile crowd formed, and the officers needed ten cover units (twenty officers) to effect an arrest. The assaulted officers and cover units then had rocks and bottles thrown at them as they attempted to leave with their prisoners. The situation continued to deteriorate, and the criminal atmosphere was clearly evident on March 9, 1990, when a Pizza Hut driver had his vehicle stolen while attempting to make a delivery within the Iris court complex. Because of this blatant criminal activity and open hostility toward public safety officials and others who visited or lived in the area, many of the law-abiding residents had become prisoners within their own homes. Their overall sense of powerlessness and abandonment was very damaging, affecting the livability of the complex and the surrounding Humboldt Neighborhood.

It should also be noted that North Precinct officers Dave Benson and Chauncey Curl recommended the Iris court location on the Community Policing Problem Identification Questionnaire. Officer Benson had also written a proposed two-day mission to his sergeant on October 11, 1989 (see Appendix C), and had written a memorandum that expressed his concern about Iris Court to then North Precinct Captain Alan Orr on October 18, 1989 (see Appendix C). Officer Benson's October 18, 1989, memo proposed "dedicating additional 
resources to this area to help curb the problem" (p. 1). In this memorandum, he reported that:

The level of violence and narcotics activity is totally out of control in this area. Especially on Night Relief this area has become very dangerous for its' [sic] residents due to the level of drug trafficking and violence. (See Appendix C, October 18, 1989, memo.)

Iris Court obviously met the demonstration project criteria of community acceptance, visibility, and validity. The involvement by the Housing Authority of Portland was evidence of community acceptance. Iris court is located in the Humboldt Neighborhood of North Portland. The location provided necessary visibility, and the support of the residents of Iris court seemed to insure that the action plan for collecting pre- and post-survey data and crime data would provide objective measurability of expected outcomes.

In addition to meeting the demonstration project selection criteria, Iris Court was an area in need of police services. As a patrol officer during the late 1970s, this researcher was assigned to a district that encompassed Iris Court. At that time the police referred to the area as Sumner Courts, and the area was "flagged" for responses to calls by two or more squad cars. Many arrests for assault, robbery and drug charges were made, and there was tension between the residents and the police. Officers were confident in predicting that they would receive several calls for service to sumner court every weekend. When attempting to locate wanted subjects, a slow cruise through 
the sumner courts was considered productive police work because it was likely that one or more persons with an outstanding warrant would be encountered.

As a Lieutenant in 1989 , this researcher observed that the police officers saw Iris Court as the same environment that he had confronted a decade ago. Those who commented about Iris Court in 1989 saw themselves as effective, high arrest, productive officers. The problems still existed, but there was optimism and hope that the community policing approach might prove successful where other strategies had failed.

\section{HISTORY OF IRIS COURT}

In 1959, the Housing Authority of Portland (HAP) and graduate students from Portland State University (then Portland state College) conducted a housing needs survey for the city of Portland. The overall results "showed the critical needs of elderly Portlanders for clean, decent low-cost public housing" (Sanders, 1991, p. 59). As a result of this study, HAP petitioned the Portland City Council for a Cooperation Agreement that would permit the purchase and/or construction of 500 additional housing units and the Council unanimously approved the petition. The growing housing needs were a result of the displacement of low-income families and elderly persons by the construction of highways and the destruction of temporary World War II 
housing. During this same year, 1959, HAP purchased the Iris Court Apartments (54 units) from the Federal Housing Administration. These units had been constructed in 1948 . They were listed in the sale literature as encompassing 54 two-bedroom dwelling units, comprising an attractive grouping of brick-faced court apartments located in North Portland just west of $\mathrm{N}$. Vancouver Avenue and immediately adjacent to Jefferson High School. Each unit has a living room, dining area, and kitchen on the first floor, with two bedrooms and bath on the second floor. When Iris court was purchased by HAP and readapted for public housing purposes, it represented the first instance of such a transaction in the Western United States.

Iris Court was initially occupied by qualified, low-income tenants. According to Richard sanders in Glimpses from the Past (1991), when a scattered site development was proposed by HAP in 1961, Iris Court had virtually all white tenants. Sanders (1991) also reported that in 1964, HAP adopted a special plan to help integrate Portland's public housing:

In efforts to deal with some racial skirmishes that had occurred at Iris court, where there were 14 African American occupants and 40 whites, HAP's special committee developed plans caliing for a tenant council, a program for preschool children and a movie on living together. This was the beginning of a concentrated effort by HAP's Board and management to solve the racial problems which had troubled it since the end of World War II. (p. 65) 
During the 1970s, HAP purchased the 46 one-bedroom apartments known as the Royal Rose and Royal Rose Annex. The 8 unit sumner court apartments were also purchased by HAP during this time period. These apartments are adjacent to the original 54 Iris court apartments and are part of the total 108 apartments that are part of this study. The next section reviews the guidelines that determine who resides at HAP low-income housing of Iris court.

\section{IRIS COURT ELIGIBILITY}

Iris court is listed in a Housing Authority of Portland brochure as Housing Assistance for Families (see Appendix D). Families may be eligible to live in HAP's low-rent units if the annual income of the household is less than $\$ 14,850$ for a two-person family. This limit increases in steps, up to $\$ 40,800$ for a family with ten members. The family's name is placed on a waiting list and the waiting period varies depending on available units. When a family appears at the top of the list, it is offered a unit of appropriate size. HAP does not offer emergency housing.

The Royal Rose Court, the Royal Rose Annex and Sumner Court are listed in a Housing Authority of Portland brochure as Housing Assistance for Individuals. To qualify, an individual's annual income cannot exceed $\$ 20,800$. The limit is $\$ 14,800$ per individual for couples. As with family housing, names are placed on a waiting list and units are 
assigned as they become available. Rents at all HAP units, family and individual, are approximately $30 \%$ of the household monthly adjusted income. If a resident is required to pay for utilities, an adjustment is made in the rent, based on the type of utility and the size of the rental unit. These allowances are updated annually by HAP and are subject to change). HAP staff are not permitted to release the exact income levels of the residents, but they report unofficially that most of the Iris court tenants are well below maximum income levels.

PROJECT OVERVIEW

After the project selection was approved by Chief Walker on March 19, 1990, this researcher was assigned as the project facilitator in addition to other duties as the Lieutenant in charge of the North Precinct Neighborhood Response Team. The North Precinct Captain, Alan Orr, was named Project Director.

Since the project was to involve community policing strategies, a number of potential partners were invited to a planning meeting on May 10, 1990. The first meeting group included representatives from the community in and around Iris Court, representatives from public safety, social services, economic services (employment specialist), education and mental health. The purpose of this meeting was to plan future actions and to indicate to the group that 
the police bureau wanted to use a nontraditional approach to address the crime, violence, drug abuse and other underlying causes of reduced livability within the Iris court complex and the surrounding neighborhood. The project would seek to interweave the criminal justice and human services systems into a single service delivery team. The approach recognized that when a police agency simply responds to calls for service, investigates crimes, and makes arrests, sustained reductions in crime do not necessarily occur. The group was advised that unless the police are willing to link up with other public and private agencies, the complicated social problems that often serve as the underlying causes of crime cannot be solved. This is the message that is advanced by advocates of problem-oriented policing, who argue that by responding to recurring problems and by working with other agencies, businesses and the public whenever possible, innovative police agencies will begin to develop effective strategies for reducing crime and other troubling conditions in our cities (Spelman \& Eck, 1989). This approach of reaching out to other providers and the public was a new one for the Portland Police Bureau. Prior to the organizational change to community policing, the focus on crime was generally a reactive one limited to enforcing laws. This focus was reflected in the old agency mission statement (Portland Police Bureau, 1990) that indicated: 
The Bureau of Police is responsible for the preservation of the public peace, protection of the rights of persons and property, the prevention of crime, and the enforcement of all Federal laws, Oregon state statutes and City ordinances within the boundaries of the city of Portland. (p. 7)

The new community-policing-era mission statement reads as follows:

The mission of the Portland Police Bureau is to work with all citizens to preserve life, maintain human rights, protect property, and promote individual responsibility and community commitment (Portland Police Bureau, 1990, p. 7).

By recognizing the complexity of the social problems facing society and the need to develop linkages with many other public and private agencies, the police bureau started to more clearly identify the problems that could be solved. This approach of looking at many needs is also evident in the views of Sar A. Levitan (1990):

Poor people need money. Whether they are young or old, their major immediate problem is the lack of income to purchase the most basic goods and services. Beyond this, however, the various groups of the poor have different needs, many of which cannot be filled with liberalized income-support programs. Family heads and young people with their life's work ahead of them must have not only mere daily subsistence but also encouragement and support for acquiring the skills sought by employers. For the aged, medical and nursing home care are primary concerns. Children also need health care and basic education to assure them opportunities in the future. (p. 23)

In other words, there is no single agency that can adequately address crime and similar complex problems by itself. 
At the beginning of a community policing venture, the value of the linkage with other agencies must be demonstrated both to police officers and citizens. Police officers need to be persuaded that being a facilitator of partnerships is not social work, rather it is "real police work." Traditionally, police officers have often seen themselves as crime fighters, available to confront danger (Skolnick, 1966). Police work has often been seen by police officers as "crook-catching" along with "asshole control" and dealing with "shitheads" (Manning \& Van Maanen, 1978). other assigned duties are to be grudgingly tolerated, at best, and not sought out. When the concept of linkage has been mentioned as part of community policing, police officers have often expressed doubt and/or hostility (Geller, 1985; Goldstein, 1990; Skolnick \& Bayley, 1986; Goldstein, 1990). However, if linkages led to successful problem solving, a decreased officer workload and subsequent rewards (medals, promotion, increased organizational status), perhaps other police officers will begin to enthusiastically engage in those linkage activities. Citizens need to witness successful police linkage, because in the past, police administrators, responding to some current "problem" such as citizen complaints about pornography stores, have demonstrated proficiency at creating new enforcement programs and illusions of responsiveness but have then quickly moved on to other 
problems. The history of changing administrators, changing community-relations programs, and escalating crime rates all combined to create doubt about the commitment of the police to community policing and the concept of linkage.

The nature of successful linkage might be likened to a medical doctor's efforts relative to a heart attack patient. Once the patient is stable and the bypass surgery is completed, treatment focuses on routine exercise, no smoking and proper nutrition. The heart specialist sends the patient to medical experts in these other three areas while occasionally seeing the patient to monitor his or her progress. If the patient avoids a future heart attack, then other patients and other doctors may be convinced that this strategy works. Similarly, once intensive law enforcement efforts have stabilized crime in a community such as the Iris court complex, the police will then direct the residents to the other linked agencies in the social service fields of employment, health and education. If the Iris Court complex and surrounding neighborhood remain stable, then other police officers, citizens and social service providers may be convinced that this approach is successful and transferable to other problem locations.

\section{PROJECT GOALS}

Subsequent meetings with the work group were conducted in order to discuss goals, structure, leadership, an action 
plan, and funding. The work group agreed that the Iris Court Community Policing Demonstration Project goals were to:

a. Improve the quality of life of the residents

b. Reduce the fear of crime

c. Reduce the level of actual crime

Quality of life was to be gauged by the following indicators: income, employment, health and education. other social measurements of quality of life that were considered but eventually eliminated included social status, mobility, family status and living environment measurements (Andrews, 1986).

Fear of crime influences the decisions people make and generally is seen as a negative life factor, even though fear of crime can sometimes be a positive force as when it prompts precautions that prevent crime. In Iris court, fear of crime was clearly a very negative matter, for among other things it caused police officers to avoid the area. When forced to be there, police officer behavior tended to be aggressive and angry. The reputation and fear of crime resulted in local pizza delivery companies refusing to provide service to the Iris court complex. Tenants at Iris Court had become fearful but passive, remaining inside their apartments with all doors and windows locked. As a result of this fear, few tenants intervened in crime situations, and potential criminals benefitted from the minimal 
community use of common space areas. This situation has

been discussed by Skogan and Maxfield (1981):

Crime in their midst undermines people's confidence that there are locally shared norms. When they withdraw from public life, distance themselves from other community members, and lose faith in the moral consensus, public places fall under the control of potential predators. In this view, crime begets crime, following a vicious spiral, and fear is incapacitating. (p. 230)

Fear is influenced by such factors as signs of physical and social decay, youth gangs and inter-group conflict (Moore et al., 1988; Wilson \& Kelling, 1989).

DESIGN, STRUCTURE, AND LEADERSHIP OF THE PROJECT

After goals were identified, the work group settled on project design, structure and leadership. The design called for the Portland Police Bureau to coordinate an umbrella group entitled the Metro-Life Enhancement Team (MET). This was to be an interdisciplinary service delivery team, involving some agencies with short-term roles and others such as the Portland Police Bureau, HAP, the Iris Court Residential Committee and the Humboldt Neighborhood Association, with long-term roles. It was recognized that as situations change, the involvement of the agencies might change. In totality, however, the effort would require the committed partnership of everyone involved.

MET was designed to be directed by the North Precinct Commander. The MET Director was assigned the task of 
leading the group and providing direction about MET police while providing periodic updates to the project steering committee. The director assigned this researcher the responsibility to facilitate the group, draft the action plan and coordinate services from the city of Portland. See Table II for a list of MET steering committee members. The major function of the steering committee was to work as a Board of Directors, offering direction to the various individuals, groups, or agencies who might have a role in implementing the various action plan items of the project (see Figure 3 for MET organizational chart).

TABLE II

MET STEERING COMMITTEE

\begin{tabular}{ll}
\hline \multicolumn{1}{c}{ Name } & \multicolumn{1}{c}{ Agency } \\
\hline Sharon Mccormack & Northeast Coalition of Neighborhoods \\
Isadore Maney & Humboldt Neighborhood Association \\
Martha Mcclennan & Bureau of Community Development \\
Gladys McCoy & Multnomah County Board of Commissioners \\
Darryl Tukufu & Urban League of Portland \\
\hline
\end{tabular}




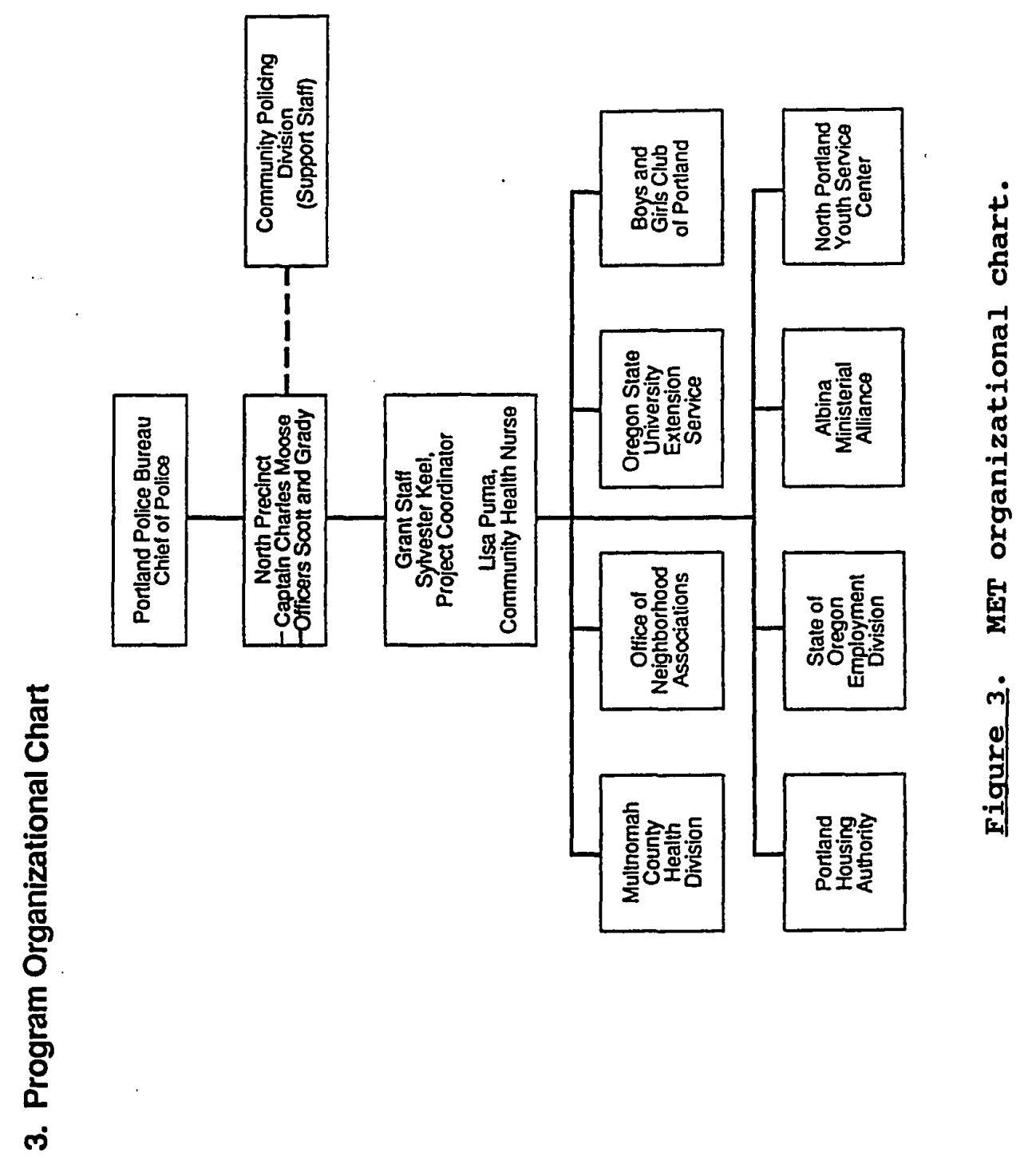


The following agencies were members of the original

MET :

Iris Court Residential Committee

Northeast Youth Gangs Task Force

Urban League of Portland

Albina Ministerial Alliance

State of Oregon office of Alcohol/Drug Abuse Program

State of Oregon Children Services Division

State of Oregon Employment Division

State of Oregon Department of Human Services

Northeast Office of Neighborhoods

Housing Authority of Portland

Multnomah County office of the chair

Multnomah County Department of Human Resources

Multnomah County Juvenile Justice Division

Multnomah County Health Division

Multnomah County District Attorney's office

The Private Industry Council

The Humboldt Neighborhood Association

Portland Public Schools

Mainstream Youth Program

Youth Resource office

Northeast Public Safety Action Committee

Portland Police Bureau

MET also had an Implementation Work Group with

representatives from the following groups: 
Housing Authority of Portland

Oregon State University Extension Service

Iris Court Residential Committee

The Private Industry Council

The Humboldt Neighborhood Association

The Youth Resource office

Albina Ministerial Alliance

Multnomah County Health Division

Portland Police Bureau

The work group was designed to implement the action plan, which is detailed in the following section, so as to empower the residents and support the residents' willingness to overcome drug use and its attendant problems.

\section{PROJECT ACTION PLAN}

The project involved several specific activities that were projected by the work group as necessary for success. These were defined, an action was described, and a lead agency for the action was identified. The project action plan (see Appendix E) consisted of twenty-one activities at a minimum, and it was recognized that other activities would also occur. The project action plan was:

PUBLIC SAFETY

1. Stabilize the criminal activity within Iris court complex.

Action: The Portland Police Bureau will conduct aggressive law enforcement actions against drug dealers, gang 
members, and other criminal elements within the area.

Lead: Portland Police Bureau (Operations Branch--Investigations Branch).

2. Take assertive follow-up and prosecution of crimes and arrests within the Iris court complex:

Action: All prosecutable cases within the target area will be intensely followed up and prosecuted as priorities. All cases to be tracked by a supervisory Detective and Deputy District Attorney.

Lead: Portland Police Bureau (Detective Division), Portland Police Bureau (Drug and vice Division), and Multnomah County District Attorney's office.

3. Provide support and structure for proactive crime prevention.

Action: The residents, the Housing Authority of Portland staff, Humboldt neighbors, the police, and public service agencies will establish effective relationships to organize and coordinate crime prevention strategies. These strategies may include information sharing, neighborhood watch, court watch, and workshops on drug and gang enforcement.

Lead: Northeast Neighborhood Crime Prevention office

4. Investigate possibilities of crime prevention through environmental design.

Action: Seek to alter the flow of motor vehicle traffic and vehicle parking within the complex. Provide a systematic review of home security and area lighting.

Lead: City of Portland Department of Transportation, Housing Authority of 
Portland, Northeast Neighborhood Crime Prevention office, Portland Police Bureau

5. Staff the on-site Neighborhood Police office that has been provided by the Housing Authority of Portland.

Action: The on-site office space that has been provided by the Housing Authority of Portland should have hours when police officers are available. During these hours the officers can share crime trend information and provide crime prevention informatior.

Lead: Portland Police Bureau--North Precinct Neighborhood Response Team and the Reserve Unit.

6. Stabilize the tenants and enforce existing tenant regulations.

Action: Take immediate action against tenants found in violation of tenant agreements, or those found involved in criminal activity at the residential complex.

Lead: Housing Authority of Portland, supported by the Portland Police Bureau.

SOCTAL

7. MET will conduct a survey of all tenants to determine needs with regard to public safety, physical and mental health, and employment and training.

Action: Design a survey instrument that is informative, but not intimidating.

Lead: Multnomah County Department of Human Services, the Northeast Workforce Center, the Northeast Neighborhood Crime Prevention staff, and the Portland Police Bureau.

8. Establish a residential committee to assist in monitoring problems and developing solutions. 
Action: Meet regularly with a tenant council to assure empowerment and immediate feedback with regards to planned programs, activities and changes.

Lead: Housing Authority of Portland

9. Provide a community center where residents can gather to discuss common issues and concerns.

Action: Conduct regular meeting with residents to focus on their perceptions and feelings as one common group and neighborhood.

Lead: Housing Authority of Portland.

10. Seek meaningful activities and structured recreation for youthful residents.

Action: Target the Iris court complex youth for organized win-win recreational activities.

Lead: Portland Police Bureau--Police Activity League

11. Provide outreach to gang impacted youth residents.

Action: Conduct one-to-one outreach to gang impacted youth residents and parents. Provide prevention education as needed.

Lead: North-Northeast Youth Gangs Task Force.

ECONOMIC

12. Provide assessment of tenants' skills for future employment and training opportunities.

Action: Evaluate skills and direct tenants to resources that support employment and development. Provide employment counseling when needed.

Lead: State of Oregon Employment Division, Northeast Youth Resource Office. 
EDUCATION

13. Provide additional training in conflict management to the on-site Iris court complex management staff.

Action: The on-site Iris court complex management staff serves as the first level of conflict resolution with many tenant disagreements. Additional training should be helpful.

Lead: Neighborhood Mediation Center, City of Portland office of Neighborhood Associations.

14. Provide linkage to General Education Development (GED) Preparation Job Readiness class.

Action: Identify residents who need and desire the skills needed to pass the high school equivalency exam.

Lead: NE Workforce Center, Portland Community College

15. Work with resident youth to increase their self-concept and increase their abilities to succeed socially and educationally.

Action: Identify possible participants for the TLC/TNT (Tender Loving Care/Think'n Try) Program. Targets are middle school age youth.

Lead: Portland Parks Bureau.

16. Work with young mothers to increase their understanding of early childhood development and form a positive peer helping network.

Action: Identify possible clients and develop a program similar to the Young Moms as provided by the Delaunay Mental Health Center and the North Portland Youth Service Center.

Lead: Multnomah County Department of Human Services. 
17. Provide law-related education to diversion and at-risk youth.

Action: Identify target residents for law-related education. "Street Law" assists young people with decisions and possible consequences.

Lead: Multnomah County Department of Human Services, Juvenile Justice Division.

\section{PHYSICAL-MENTAL HEALTH}

18. Evaluate the health needs of the Iris court residents.

Action: Have an on-site Health Fair in order to evaluate the health and nutritional needs of the residents. Make field nurses available.

Iead: Multnomah County Department of Human Services, Multnomah County Health Division.

19. Support domestic violence victims within the Iris court complex.

Action: Establish support groups, provide counseling, assist in reducing future victimization.

Lead: Multnomah County Office of Women's Transition Services.

20. Provide on-site physical and psychological care to residents.

Action: As a result of the number of single parent households and area wide drug and alcohol availability, treatment and prevention should be readily available without the additional stressors of child care and transportation.

Lead: State of Oregon Drug and Alcohol Program and Mainstream Youth Program.

21. Provide child care for parents seeking self improvement opportunities. 
Action: Maximize area child care and assist parents while assuring youth of a proven Head start program.

Lead: Albina Ministerial Alliance Head Start Program.

\section{ACTION PLAN IMPLEMENTATION}

The action plan was designed as a road map to be followed by a lead agency, but those agencies were also encouraged to involve other agencies and tenants whenever possible. When meeting as a group, MET members were to discuss progress, success, problems and possible solutions. Other MET members were to offer to assist a lead agency or provide ideas of methods to modify the action plan item. At the initial meeting of the MET group on May 10, 1990, the point was emphasized that everything that was to be accomplished within the Iris court complex had to be done with existing resources. In other words, no new funds would be available and no existing funds would be transferred from other programs. The announcement caused a good deal of concern. The 1989-90 budget year was coming to a close, and the 1990-91 budgets had already been drafted. It was not clear how any social service group was supposed to deal, with the conditions within Iris court without additional revenues.

However, the group was attentive while the concept of community policing was explained, and after several 
meetings, the previously listed action plan was produced. Members of the group openly discussed doubts about implementation because of limited budgets and heavy workloads, and each day a new need for many of the residents and the possible social service provider seemed to surface.

A few activities got the project started without any additional resources, but it became more and more difficult to get agencies to focus on Iris court. For example, without a service provider or police coordinator on the grounds, many of the invited providers felt unsafe. Many MET members also reported that they did not feel a project was truly in effect because of the limited activity observed.

With these resource problems in mind, a grant application was prepared and submitted to the Bureau of Justice Assistance, Office of Justice Programs, U.S. Department of Justice. The application was under the area of Innovative Neighborhood-oriented Policing and was entitled "Community Partnerships--A Community Policing Model for a Drug Demand Reduction."

The original June 18, 1990, grant application was revised on October 4,1990 , and on December 12, 1990, the Portland City Council accepted a grant of $\$ 200,000$ from the Bureau of Justice Assistance with the passage of Ordinance No. 163684. Table III shows the grant funds for the Iris Court project. The remaining grant funds were utilized for 
TABLE III

GRANT FUNDS FOR IRIS COURT PROJECT

Item

Amount

Full-time employee: 1 FTE, Coordinator

$\$ 31,990$

Benefits for Project Coordinator

12,792

Professional services contract with Multnomah

36,146

County Health Nurse

Follow-up studies by community members $\quad 5,680$

conducting the survey

Total

86,608

a citywide landlord tenant training program that had no relationship with Iris court.

Under the guidelines of the grant, the Project

Coordinator and the Community Health Nurse were to have the

following duties:

Project Coordinator - strive to ensure linkage

between residents and all of the various service

providers working to improve the quality of life

in the Iris Court complex. Responsibilities

include family assessments, referrals, indirect

counseling and follow-up to assure connections

are completed. Keep records and write reports to document activities. In addition, the

Coordinator will organize outreach activities, participate as a member of the MET work group, implement effective scheduling and strive to assure a team approach to service delivery in areas of ongoing planning. 


\begin{abstract}
Community Health Nurse - provide services in residents' home environments and be available for site visits. Conduct individual and family assessments, provide needed short-term treatment, make referrals to other health and human service agencies, and follow residents' progress to make sure they receive needed care. The nurse is expected to help decrease family and community dysfunctional behaviors resulting from underlying physical, mental, emotional, and/or social

problems. This position is expected to improve resident access to drug abuse prevention information. (Bureau of Justice Assistance, 1991, p. 20)
\end{abstract}

The Project Coordinator was hired on January. 22, 1991. In April 1991, all of the contract agreements had been signed, and the nurse from the Multnomah County Division of Health had been selected and had started to work at Iris Court. The Project Coordinator reported to the North Precinct Command staff, and the nurse reported to the supervisory staff at Multnomah County Division of Health. See Figure 4 for the demonstration project organizational chart.

EVALUATION DESIGN

The Iris Court Community Policing Demonstration Project was designed as an innovative program. To this point, the problems within Iris court have been described, the goals of the project have been explained, the action plan has been presented, and the federal grant has been addressed. Since the purpose of this project was to evaluate the strategy of community policing, the research 


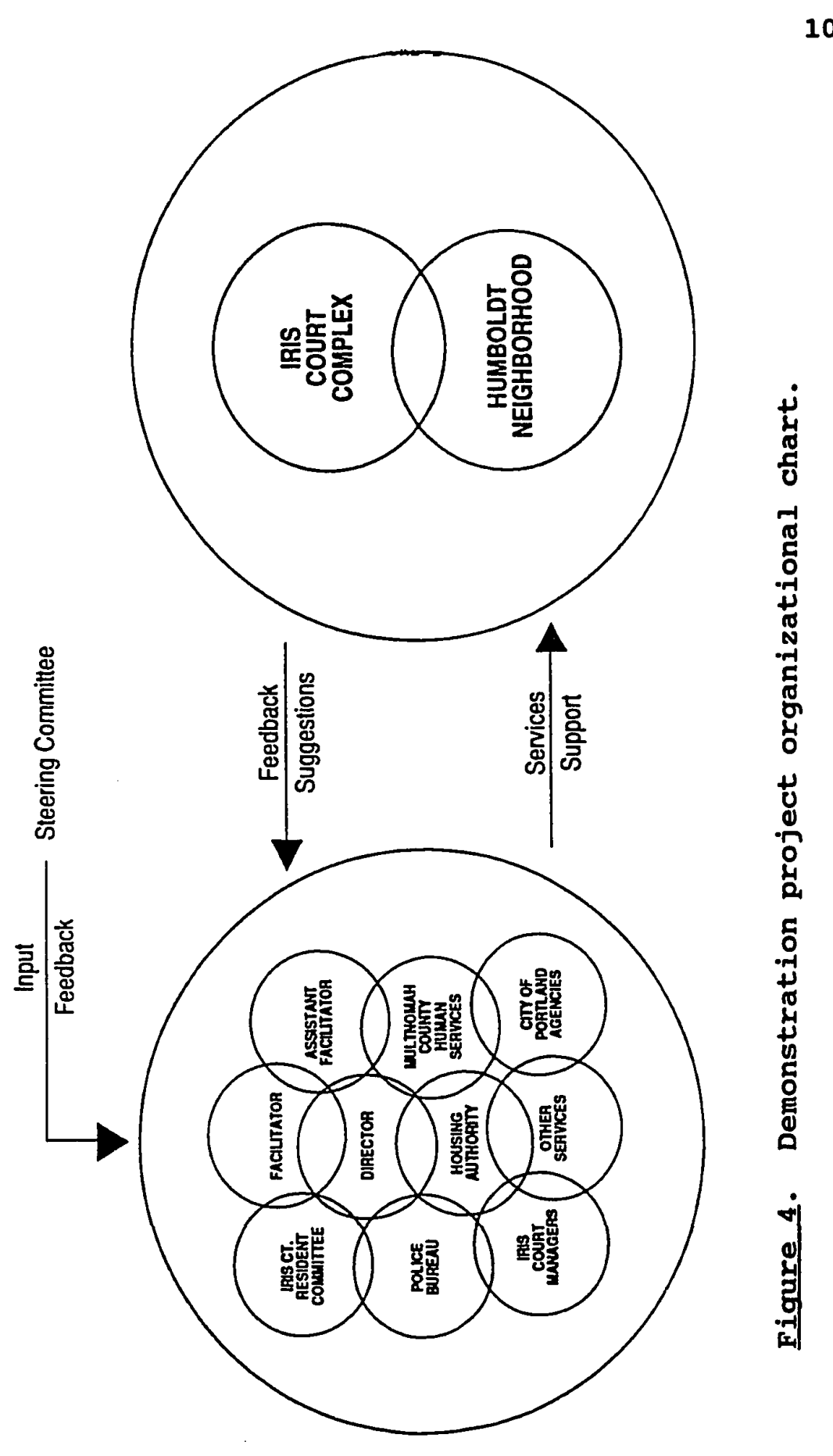


evaluate the strategy of community policing, the research design called for a process review and an outcome evaluation of the project.

\section{PROCESS EVALUATION}

In conducting program evaluations, process reviews ask: "Did you do what you said you were going to do?" In other words, a process review determines if the operational aspects of a project were executed as planned (Gibbons, Thimn, Yospe \& Blake, 1977). The Iris Court project review concentrated on three areas:

1. Implementation of the action plan with a review of whether each action plan item was accomplished;

2. A chronological review of events that occurred at Iris court to determine if the events influenced the goals of improving the quality of life, reducing the fear of crime and reducing the reported crime; and

3. A review of events as they relate to the Portland Police Bureau goals for community policing.

OUTCOME EVALUATION

The outcome evaluation examined the impact of the independent variables (policies and action plan items) on the dependent variables of improvement of residents' quality of life, the reduction of residents' fear of crime, and the reduction of reported crime. 
The overall outcome review design combined a number of methods to assess different activities. This use of several different research methods to investigate the same hypothesis or problem is sometimes called triangulation (Babbie, 1989). This review combined qualitative and quantitative methods which were selected for the following reasons. First, the two methods built upon each other and offered insights that neither one alone could provide. Additionally, taken individually, all methods have biases, so only with multiple techniques could we expect to gain a better understanding of the underlying reality. Then, too, the interweaving of the criminal justice and human service systems called for a wide array of conceptual and methodological tools. Fourth, this was a living project in an operational world, not a test in a sterile laboratory where randomness, coincidence and chance can be controlled. Finally, this was applied research carried on for the practical reasons of determining what strategies might be applicable, practical, and immediately useful in similar environments.

The outcome review utilized a one-group pretest and posttest design. This pre-experimental design was implemented because there was no readily available control or comparison group, and this design maintained public service integrity because no requested services were 
withheld for the sake of a quasi-experimental or experimental project.

As a living project in an operational world, there were several influencing factors to consider with the outcome review. First, the target population was expected to "come and go" because of the historically high turnover rate for public housing tenants. The tenants present during survey periods were asked to complete the questionnaire even though they may not have been exposed to the community policing strategies during the entire outcome review period. Second, the evaluation recognized that many outside events may influence the outcome. Community policing in Portland calls for many and varied participants. There was an expectation that the private sector, neighborhood groups, and other government agencies would attempt to combat crime within this demonstration project focus area. Labelling all of these activities as community policing makes sense for purposes of this evaluation, but it must also be acknowledged that these non-police contributors had been actively helping with neighborhood problems for many years. clearly, community policing is not a "stand-alone" solution, and when dealing with a very complex set of social issues, we must not think we have found a simple solution. Hopefully the atmosphere and attitudes fostered by community policing will enhance the efforts of these other groups. In 
other words, any success that is observed must be seen as shared success.

Third, Portland's government-supported community coalitions (the Iris Court area is served by the Northeast Coalition of Neighborhoods) must be recognized as strong contributors to any public safety success. This recognition must also include the Crime Prevention Specialists who work for the Northeast Coalition of Neighborhoods. The community organizing and crime prevention methods practiced by these individuals were not replaced, rather they were enhanced by police officers finally realizing that neighborhood block watch, court watch, and citizen foot patrols are all vital parts of reducing reported crime, reducing the fear of crime, and improving the quality of life. It is important to understand that these crime prevention strategies were not new and revolutionary. The Northeast coalition of Neighborhoods was involved with the Iris Court demonstration project from the start, and one of the coalition's crime prevention specialists sat on the project steering committee.

Fourth, an important design problem is measurement unreliability. A reliable measure is one which repeatedly gives the same result (Kidder, 1981). For example, a gym scale is reliable when it repeatedly weighs a dumbbell of unchanging weight at fifty pounds. If the scale gives 
different readings on repeated weight checks, it is unreliable.

There are also threats to reliability when measuring qualitative psychological states (e.g., attitudes, values, feelings) with regard to fear of crime, neighborhood livability, quality of life, and attitudes toward the police. These perceptions probably change over time, quite apart from influences such as the inauguration of community policing. Also, respondents may have varying interpretations of the same questions because of sentence structure, differences among interviewers, variations in interview settings, respondents' past life experiences, and their moods at the time of the interviews. While recognizing that threats to reliability cannot be entirely eliminated, it is hoped that these were reduced substantially through the construction and consistent use of the measurement instruments.

Lastly, the residents' reactions may be influenced by the reactive effect of experimental arrangements. This means that "in order to carry out an experiment, it is often necessary to make special arrangements; there is then the risk that these arrangements may interact with $x$ to produce an effect, whereas without these arrangements $x$ would have no effect or an effect of a different magnitude" (Moser \& Kalton, 1972). The reactive effects of experimental arrangements are sometimes referred to as compensatory 
rivalry or "the Hawthorne Effect." Since this community policing project was a mandated public event, the target population may have been aware of this enhanced attention directed at them and may have worked harder to improve at a rate greater than tenants in other housing complexes. Also, the police officers who worked in the project area may have seen themselves as specially selected and sought to be innovative, friendly problem solvers who wanted to be viewed as successful. And since a portion of the outcome review was based on pretest and posttest conditions, the likelihood of false outcomes may have been increased by the project openness, publicity and visibility. Although these are potential problems, hopefully the evaluation data provide a relatively accurate account of the project and its outcome. Chapter VI, to which we now turn, reviews the process review findings, that is, it addresses the question of what happened and whether the project implementation followed the plan. 
CHAPTER VI

PROCESS REVIEW FINDINGS

As indicated in Chapter $v$, the Iris court Community Policing Demonstration Project process review was designed to concentrate on three areas: the action plan, a chronological review of events, and a review of events as they relate to the Portland Police Bureau community policing goals of partnership, empowerment, problem solving, accountability and service orientation.

\section{REVIEW OF THE ACTION PLAN}

Overall, 18 of 21 action plan items were implemented (see pp. 94-100). This was a significant accomplishment, because there were no direct costs to the City of Portland General Fund. In the event that the projected lead agency did not implement the action plan item, it was usually a similar service agency that did so.

What items were not accomplished? No additional training in conflict management was made available to the on-site Iris court management staff (action plan item \#13). Although this seemed to be an important goal during the early stages of the project, the team approach to most problems relieved the pressure on the two on-site managers 
who had the task of doing almost everything for the tenants before the project started. In other words, the Federal grant-funded coordinator and the various police officers who were coming and going seemed to do much of the conflict management once the project started. Additional training would certainly have been helpful, but it did not appear that this training was critical once it became clear that many individuals were available to assist the on-site managers with conflict management.

Another unaccomplished goal was the linkage to the General Education Development (GED) Job Readiness class. Whenever the project staff sought to find interested parties for this class, the numbers did not justify bringing it to Iris court. Further, the Portland Community College instructors consistently reported that sufficient low-cost enrollment slots were available there if people would just attend the sessions. This action plan item did not prove to be a critical one.

Action plan item \#17, the law-related education to diversion for at risk youth, was not accomplished. Most of the Iris court children were too young for this program. The few who were old enough were not involved in any Juvenile court diversion and, consequently, were not eligible.

A detailed discussion of the accomplished action plan items is presented in the chronological review below and the 
review of events as they related to the Portland Police Bureau goals for community policing.

CHRONOLOGICAL REVIEW OF PROJECT EVENTS

This review endeavors to show what happened during the Iris Court Community Policing Demonstration Project. The description of events that follows shows the internal workings of the project and offers some insight as to what worked to change the crime riddled environment at Iris court.

\section{May 1990: Tenant Survey}

Prior to the project start-up, a "baseline" survey was conducted of the residents and of the North Precinct police officers to obtain information on living conditions and problems at Iris court. The tenant survey also sought information about what tenants thought should be done to improve Iris court. It revealed a high level of fear of crime, and uncovered other economic and social problems, providing information which served as a guide for the public and private efforts to correct these conditions. (For additional information about the surveys, see Appendices $E$ and F).

\section{May 1990: Enhanced Police Presence}

North Precinct opened a Community Contact office within the Iris court complex (315 N. Sumner, \#3) to improve 
police contact with the public and to provide an operational base for the Iris Court project. For several weeks the office consisted of a room, an old couch, and a telephone. But one afternoon Captain orr was contacted by a citizen in a U-Haul truck who said he had ten desks for sale. After a quick check it was determined that this person was a licensed wholesaler, and the project now had ten pressboard desks! Additional "deals" were located, and eventually the office had telephones, file drawers, a copy machine, a coffee machine, and an old microwave oven. Since one goal was to entice North Precinct officers to use the office and subsequently create an increased presence at Iris court, a color television was secured from city property control and a cable line was put into the office; because the city of Portland has an agreement with the cable companies, basic cable to any City facility is free. Following these developments, police officers began to stop at Iris court for lunch or for other reasons. Apparently the ESPN sports channel and CNN news channel were very popular during the evening hours. In any event, police visibility and interaction with Iris court tenants increased and probably helped to reduce crime and the fear of crime.

The Portland Police Community Policing Division designated a staff liaison person for the Iris court project. The Division's role was to concentrate the community analysis problem-solving procedure on the target 
area, including such elements as computer mapping of criminal activity, an information and referral component, the training of officers in community policing strategies, crime prevention programs, and other support functions.

\section{May 1990: Occupant Pattern Stabilized}

In addition to an enhanced police presence in Iris Court, the problems of drug use on the premises and illegally occupied units were dealt with by HAP. HAP began rigorous enforcement of existing housing laws and other local regulations, and during the latter days of May 1990, it started to re-rent several units that had been vacant because of aggressive enforcement of drug laws by the police. HAP management staff reported that they had several telephone calls from staff in Washington, D.C. because they had exceeded acceptable vacancy rates. In other words, the ten drug warrants and following evictions served as a "red flag" to some official in Washington, D.C. that Portland had fallen behind on occupancy ratios. The eviction data presented in Table IV were provided by HAP. (For additional information on evictions, see Appendix G.)

The evictions listed as outrageous conduct and unauthorized guest were directly related to police activity, which means that the cases were originated by police officers and the reports were sent to the decision-makers at HAP who subsequently conducted follow-up interviews and investigations prior to the actual eviction. Several of the 
TABLE IV

EVICTION DATA

\begin{tabular}{lc}
\hline Evictions by Category & $\#$ \\
\hline Outrageous conduct--drugs & 3 \\
Outrageous conduct--rape & 1 \\
Unauthorized guest & 1 \\
Combination (rent--unauthorized guest) & 1 \\
Unknown (prior to records) & 5 \\
Nonpayment of rent & 12 \\
\hline Evictions By Calendar Year & $\#$ \\
\hline 1989 & 13 \\
1990 & 10 \\
1991 & 0 \\
\hline
\end{tabular}

Note. Data supplied by Housing Authority of Portland.

nonpayment cases were the result of drug warrants and the seizure of suspected drugs and money. The lack of evictions in 1991 does not mean that HAP or the police had grown "soft" or looked the other way; it suggests that the remaining tenants had started to be aware of the relationship between their behavior and their housing. An example occurred during 1991 when there were three 
individuals visiting and living in and about the complex although they were not on a lease agreement and were generally seen as troublemakers. At the request of police officers, HAP sent letters to all of the Iris court tenants informing them that continued association with these individuals could lead to eviction, or at minimum, a show-cause hearing. This letter caused an uproar and was the main topic at the tenant meeting; in the end, however, the three individuals found themselves isolated. Left without a "safe house," their improper behavior resulted in their arrest and subsequent exclusion from the Iris court complex. Although there is no clear way to demonstrate the claim, it appears that the twenty-three evictions had some positive impact on the decisions of the tenants.

Included in the enhanced police presence was the utilization of a trespass procedure that was developed by the police bureau and HAP. The eviction process is a very helpful tool when a person is on a lease, but one of the major problems at Iris Court involved individuals or groups of individuals (gangs) who frequented the complex to drink alcohol, sell drugs, and intimidate and victimize residents.

HAP, the police bureau, and the Multnomah County District Attorney's office worked together to find a solution to these problems posed by trespassers. The result was an "Exclusion Process" from Housing Authority of Portland property. The process was started by HAP granting 
authorization for police officers to act as their agents for the purpose of giving trespass notices to nonresidents of HAP properties. The officers were considered "persons in charge" as defined in Oregon Revised statutes (ORS) 164.205(5). Before persons could be excluded, they had to meet the "criteria for exclusion" (Portland Police Bureau, 1992) :

1. Makes unreasonable noise;

2. Engages in fighting or in violent or threatening behavior;

3. Substantially interferes with any right, comfort or convenience of any HAP resident or employee;

4. Engages in any activity which constitutes a criminal offense;

5. Engages in any activity involving firearms, illegal drugs or violence;

6. Damages, defaces or destroys any property belonging to HAP, or any HAP resident or employee;

7. Litters on any HAP property;

8. Drives in a careless or reckless manner;

9. Consumes or possesses an open container of any alcoholic beverage on the common areas without being accompanied (meaning actual physical presence) by a resident of that development or an adult family member of the resident's household; or

10. Engages in gang activity, including but not limited to:

a. Wearing clothing, jewelry, or tattoos unique to gang affiliation (color alone is not sufficient to establish gang affiliation); 


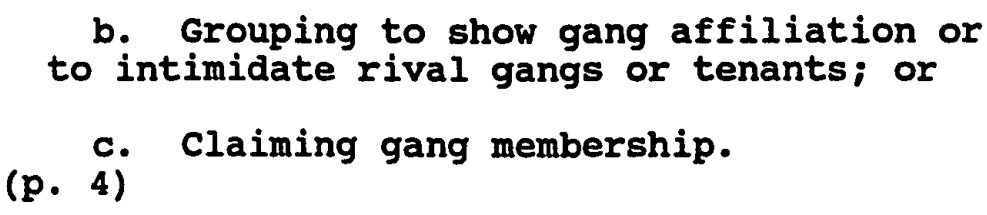

Any person who failed to leave the property after being directed to do so, or who returned to the property after being given such direction, was subject to arrest and prosecution for Criminal Trespass under ORS 164.245.

When a police officer observed a nonresident violating one or more of the above criteria, that person could be excluded on a HAP exclusion form. The nonresident was given a map of the property to assure that he or she was very clear as to the area from which he or she was being excluded. The process was completed with a Portland Police Special Report, and a photograph of the nonresident was posted at the Iris Court Police Contact office. The nonresident also had the right to an appeal with the HAP Trespass Control officer. When and if an excluded individual did return, the tenants were able to serve as the eyes and the ears of the police without having to actually come forth and testify. Once they told the police that the individual was in the area, the police only needed to see the person to assure his or her arrest for trespass. And if an individual decided to change his or her lifestyle, the appeal process was available.

From August 15, 1989, until March 31, 1990, 94 people were excluded from the complex. of those, 77 or $82 \%$ were 
Black males, 15 or $16 \%$ were Black females, 1 was a white male and 1 was a white female. The reasons for the exclusions were as follows: 54 or $58 \%$ for drugs, 13 or $14 \%$ for gang activity, and 9 or $10 \%$ for drinking. Also, 6 or $6 \%$ were unknown, 4 or $4 \frac{8}{6}$ were for riot and/or assault, 2 cases were for theft, and 1 was for reckless driving. (For more details about these exclusions, see Appendix H.) From April 1990 until August 1991, three people, all Black males, were excluded from the Iris court complex for fighting.

The exclusion-trespass process was a useful tool. Problem residents on a lease were dealt with through landlord-tenant laws, and nonresidents were dealt with by the exclusion-trespass agreement. Neither system depended on a locally overburdened criminal justice system, and both had a fairly immediate impact on a problem situation. The exclusion criteria were set by the landlord (HAP) and therefore were flexible enough to be modified as trends and circumstances developed. For example, if motor-driven water guns became a problem, the use of such toys could be added to the criteria list. The overall process of exclusiontrespass was challenged by several Multnomah County District Court Judges, but once maps were made part of a package and an appeal process was documented, approval was granted. The end result was that problem individuals and groups decided to remain out of the Iris court complex. 
While this process potentially displaced a problem to another location rather than completely eradicating it, it did prove effective for reducing criminal and disorderly behavior within the Iris court complex. In other words, the exclusion did not help the entire city, and the involved individuals did still have some serious antisocial traits that needed attention, but the exclusion helped the taryet area of the demonstration project. Some saw this as traditional law enforcement, but the innovation and the lack of dependence on the criminal justice system made the process an excellent community policing tool. Not only did it provide a consequence for violations, it also was quick and allowed the law-abiding residents to play a role in improving their neighborhood. In addition, it served as a model and is presently being used in several privately owned apartment complexes. (For additional details about the exclusion-trespass process, see the Portland Police Bureau Trespass General Order, Appendix I.)

June 1990: Crime Prevention Through Environmental Design (CPTED)

Another Iris Court community policing strategy involved structural improvements to create a safer environment. Based on research by Newman (1972), the strategy seeks to deter crime by alterations in environmental features and reduction of crime opportunities instead of attempts to change people. As discussed by 
Poyner (1983), a crime problem is solved by removing or reducing targets. Although there were no data demonstrating any increases or decreases in crime as a result of structural changes, changes were completed with public safety in mind, and there were some costs involved in those structural changes.

The first change was to make one apartment into a Portland Police Contact office in order to increase the police presence and serve as a center for all public safety efforts within Iris court. HAP reported that the revenue lost from this apartment, which was provided to the city of Portland at no cost, was $\$ 206.35$ per month.

The second change involved the blockage of North Sumner street and the posting of the north side of the street for no parking. Creating a dead-end street reduced the ability of persons to drive through the area to conduct drug sales. This dead end also meant that when persons drove into Iris Court, they should have had a valid reason for doing so because of the extra trouble posed by turning around before being able to drive out. In addition, the area where persons could stop and turn around was outside the window of the Police contact office. The cost for the dead-end structure was $\$ 20,000$, paid for by the City of Portland using grant funds.

The third design change involved the laundry facility. In prior years, the various buildings had laundry machines 
in basement locations which were equipped with doors that were self-locking from the outside when closed. The expectation was that the manager would prop open the doors every morning and that they would remain open all day, but what actually happened was that people entered the basements, closed the doors behind them, and then broke into the machines, used drugs, and victimized whoever happened to be in the basement. As a result, the laundry facility was very unsafe and almost useless. As part of the overall commitment to community policing and Iris court, HAP created an aboveground, clean, functional, and safe laundry facility by remodelling one of the two-bedroom apartments. In addition, the Iris court Tenant council scheduled the hours of operation and kept the facility clean. The cost of the change was $\$ 22,500$, paid for by HAP.

The fourth structural project was the resurfacing of a rock- and glass-covered basketball court. The public safety aspect of this project was less direct, but it helped to bring the complex together as a neighborhood and improved the quality of life for residents within Iris court. After its completion, parents knew where their children were and the latter no longer found the street to be the most attractive place to play.

Taken together, these changes helped to increase the tenants' sense of territoriality and community. Defensible space measures have turned Iris court into a community in 
which both tenants and strangers perceived that the area was under the undisputed sphere of influence of the tenants. The sense of ownership and accomplishment was evident in the Iris Court slogan: "We are Iris court Proud."

\section{July 1990: Community Networking--Job-Health Fair}

A Job-Health Fair conducted within the Iris court complex involved twenty-five service agencies and businesses which provided recruiting and training information. These agencies and businesses were joined by neighborhood organizations, as well as City of Portland and Multnomah County officials. Several local groups provided entertainment from atop an Oregon Air National Guard flatbed truck. The Norman Sylvester Band was the highlight group, while Safeway Inc., the Portland Police Sunshine Division and other agencies donated food and beverages that fed 400 area residents. The purpose of this event was to provide access to information and to start to build a sense of pride and community.

\section{October 1990: Unity Events}

By making use of the contact office facility, as well as the community center, several events and get-togethers were developed to involve all members of the community, although the focus group was the children in the complex. These events included an open house at the contact office on October 16, 1990, a Halloween party at the Community Center, 
and birthday cards with the North Precinct logo which were mailed to residents on their birthdays.

\section{November 1990: Employment and Nutrition}

The State of Oregon Employment Division authorized an Employment Specialist to spend 20 hours per week at Iris court. This worker scheduled time with tenants to assess their skills and training needs and to target them for employment.

Also, the oregon State University Extension Service started conducting nutrition classes. A twice weekly after-school class, "Snack Attack," targeted elementary school children to teach them about health and nutrition (see Appendix J). Byproducts of the program were increased self-esteem and a sense of personal competence through involvement in positive group activities and development of cooking skills.

December 1990: Christmas Party

The Sunshine Division, members of the Northeast Public Safety Action Committee, and a local Marine Reserve Unit (Toys for Tots Program) combined to host a Christmas Party for Iris Court tenants. A local Black businessman played Santa and arrived at the snow-covered complex in a limousine driven by a Portland Police officer. That vehicle had been seized from a drug dealer earlier in the year! All residents enjoyed delicious food and received presents. 
February 1991: Tenant Council

A racially mixed group of young and middle-age men and women tenants started to seriously work on the formation of a Tenant council. This group formed to assist in monitoring problems and developing solutions within the neighborhood. This willingness to organize and accept responsibility was demonstrated when the tenants organized and hosted a Valentine's Day party, an event which probably contributed to the development of a sense of community for the once fragmented and isolated Iris court tenants.

\section{April 1991: Circus}

Resident adults served as chaperons for the Iris court children who attended a circus production at Memorial Coliseum. The admission tickets were provided by the Sunshine Division, lunch was provided by a local business (the Bee Company), and transportation was aboard local Tri-Met buses that were donated.

May 1991: Self-Esteem Events

A crime prevention specialist from the Police Bureau Community Policing Division conducted several "Women Strength" self-defense classes for the younger adult female tenants of Iris court. In addition to the skills taught during the classes, information was provided about how to make referrals to agencies that provide support to victims of domestic violence. 
The Portland Boys and Girls club started coming to Iris court twice a week to pick up children and transport them to the North Portland club for sports and recreational activities. In addition, the North Portland Youth Service Center started to work on-site at Iris court with its Parent/Child Development Program. This "Great Start" program worked with young parents, providing both prenatal counseling, parenting and emotional skills to parents with babies up to 30 months in age.

The preceding list of events does not include everything that occurred at Iris court during this review period, rather these are the most noteworthy and documented events. Some of the events will be mentioned again in the next section when discussing the relationship of events to the Portland Police Bureau goals in order to demonstrate how those events related to an agency goal.

RELATIONSHIP OF PROJECT ACTIVITIES TO BUREAU GOALS

As noted earlier, the police bureau goals for community policing were partnership, empowerment, problem solving, accountability and service orientation. The partnership goal was met in several ways, the clearest of which was the forming of MET to undertake problem identification and problem solving. This team was formed without special funding and without public or private mandate. Agency representatives and community members 
simply agreed that working together was the preferred strategy. For example, under the MET approach, the police bureau shared information with HAP, and the two agencies worked together on evictions and trespass actions that enhanced the public safety agenda of the action plan. The police bureau and the Multnomah County District Attorney's office formed a partnership to track prosecution cases so that Iris Court matters would not get overlooked or lost in the bureaucracy. The police bureau and the transportation bureau combined efforts to have North Sumner street blocked off and in effect to create cul-de-sac living for the Iris court tenants. This crime prevention through environmental design tactic greatly reduced the random drive-through traffic that affected the liveability of the complex. The Bureau of Justice Assistance joined the partnership and the resulting funding provided a coordinator and community health nurse. The police bureau, the Private Industry Council, the State of Oregon Employment Division and HAP combined to open, furnish, and staff an on-site contact office. All of these partnership strategies were indicators of a new style of cooperation for the police bureau. During implementation of the Iris court project, several events demonstrated empowerment. The Northeast Coalition of Neighborhoods crime prevention specialists worked with tenants to assure an effective "apartment watch" program. Each building in the complex had a block Captain 
and there also was a complex block Captain. HAP provided a meeting space and training for the Tenant Council in order to help the residents start to make decisions and work together on policies and events at Iris court, including such things as an Iris Court newsletter (see Appendix $\mathrm{K}$ ) and other activities from within the contact office.

Another instance of empowerment occurred when the tenants took a lead role in the annual Iris Court Job-Health Fair. The first of these was organized by MET, but the second one was chaired and organized by the Tenant council. other activities that resulted in empowerment were the North Portland Youth Service Center "Great Start" parenting classes, the police bureau-sponsored "Women Strength" classes to teach assertiveness and defensive tactics to females, and the Oregon State University Extension Service child-oriented "Snack Attack" nutrition classes.

other empowerment strategies that focused on children were the police bureau sponsorship of Iris Court children in the St. Andrews Church "Ask OMSI" science program, the involvement of Iris Court children in the North Portland Boys and Girls Club, and the Police Activities League sponsorship of Iris court children to a summer quickness camp, an airplane ride, a trip to a three-ring circus, a B.B. King concert, a seattle seahawk football game, and several professional hockey and baseball games. 
The community policing strategy of problem solving was demonstrated when HAP and police bureau collaborated to develop trespass procedures. HAP practiced problem solving with the redesign of the laundry facility, the enforcement of parking regulations that prohibited leaving broken-down vehicles in the parking lots, and the hosting of regular Tenant council meetings to identify conflicts, monitor problems and develop solutions. When the oregon state University Extension Service could not continue to fund the "Snack Attack" program, the program was saved through a grant from the Bureau of Community Development. The Albina Ministerial Alliance solved a child education problem by allocating more space to Iris court children at the on-site Head start program.

The goal of accountability was met with quarterly updates to the Bureau of Justice Assistance, monthly reports to the chief of Police and the City Council, and monthly reports to the project steering committee. There were no events that demonstrated service orientation, although it could be argued that the many extra efforts and visits by various North Precinct officers were indicators of service orientation.

The previously mentioned activities of the action plan, the chronological review, and the relationship of the events to the community policing goals all indicate that the operational aspects of the project were implemented. Some 
of the events proceeded exactly as planned and many were tailored to meet circumstances and available service providers. Overall, the project accomplished most of the planned goals. 
CHAPTER VII

OUTCOME REVIEW FINDINGS

\section{RESIDENT SURVEYS}

Two of the dependent variables--improvement of the quality of life and the reduction of residents' fear of crime--could not be assessed using data that are routinely collected by the Portland Police Bureau. While the bureau engages in counting and tracking reported crimes, it has no mechanisms to count or measure quality of life and fear of crime (or unreported crime, for that matter). Accordingly, a survey instrument was developed to assess quality of life and fear of crime, and particularly to gauge the changes, if any, that resulted from community policing. The questionnaire consisted of both open- and closed-ended questions. The instrument was presented to and approved by the Human Subjects Research Review Committee at Portland State University to assure the protection of the interviewees. The committee determined that it was an acceptable instrument, because it resulted only in anonymous responses; thus, specific individual respondents could not be identified in those data.

The surveys were conducted by interviewers going door to door. The baseline or pre-project survey was conducted 
by community members under the guidance of the Northeast Public Safety Action Committee, a group made up of crime Prevention representatives from North Portland neighborhoods. The survey takers attended a three-hour training session conducted by this researcher (see Appendix L). This training covered the details of the survey along with instructions on introductory statements, positioning during the interview, and recording procedures. The training included mock interviews that were critiqued by those attending the training class. This session resulted in some revisions in the survey instrument. For example, the demographic items were moved to the end of the survey instrument, because the members of the survey class thought the requested information was too personal to be elicited at the start of an interview. Several questions were reworded because having them read aloud demonstrated the awkwardness of those items.

Prior to interviewers knocking on doors, notices were mailed out by HAP explaining that members of the office of Neighborhood Associations would be asking questions in an effort to make Iris Court a better place to live. The interviewers were identified as being associated with the larger Office of Neighborhood Associations to insure that the residents did not feel that they were being questioned by HAP (their landlord) or by the police bureau. The interviewers were dispatched in teams of two, with one 
member assigned to record while the other read the questions. The baseline survey was conducted during the week of May 20-25, 1990. On May 11, 1990, an article in The Oregonian announced the first public planning meeting to start the Iris Court Community Policing Demonstration Project.

The post survey was conducted during the week of July 30-August 3, 1991. It was contracted out to the Piedmont Neighborhood Association, with funds being provided by the Federal Bureau of Justice Assistance grant. The Piedmont Neighborhood Association used community residents along with several members of the Northeast Public Safety Action Committee who had participated in the baseline survey to conduct the post project survey. All interviewers attended a training class conducted by this researcher. The following questions were added to the post survey to elicit information that could be used to make any necessary adjustments to the ongoing experiment (see Appendix E):

\#34. Have you met Dave Grady and scott Johnson on the Neighborhood Response Team?

\#37. What changes or additions would you like to see in the services provided in Iris court?

\#38. Have you participated in the Tenant Association? NORTH PRECINCT OFFICER'S SURVEY

When the Iris Court Community Policing Demonstration Project was initiated, it was anticipated that in addition 
to attaining the three stated goals for the project area, it could assist the police bureau management staff in discovering strategies to be used to change the entire philosophy of the agency to one of community policing. Consequently, several questions in the officer's survey centered on internal change issues and not on conditions at and around the Iris court complex. The survey was selfadministered at North Precinct over several days during roll call for the various shifts. The Precinct Sergeants distributed the survey but did not offer instructions other than to say that these surveys had to be completed prior to going on the street and were needed for community policing. A staff shortage and the requirement for officers to leave the precinct to respond to calls in the neighborhoods hindered the possibility of having interviewers complete the surveys.

The baseline survey was completed by 61 or $44 \%$ of North Precinct officers. The post survey was completed by 69 or $49 \%$ of North Precinct officers. The officers who took the time to complete the survey demonstrated little knowledge about Iris court and even less interest in using their best judgement to correctly complete the survey form. The survey instructions called for the respondent to provide the answer that best indicated his or her feelings from the given choices, yet the officers left many questions 
unanswered and wrote in "don't know" instead of checking a response that best indicated their feelings.

Unfortunately, the refusal of so many officers to complete either the baseline or the post surveys rendered the results essentially useless. There was no information from either of these surveys that proved useful in determining whether or not the Iris Court community Policing Demonstration Project was a success or failure from the standpoint of the working police officer. Further, there was no information that was useful to the police bureau in determining the proper strategies for the implementation of community policing. (For a review of the North Precinct Officer Survey results, see Appendix F.)

A major lesson learned from this experience was that self-administered surveys are a gamble. Although having interviewers contact the officers when they were not pressured to go to work would have been difficult, the product would doubtless have been more useful. The self-administered survey process was a failure. Perhaps the officers performed as they did because of peer pressure to reject community policing as "social work" or perhaps they performed as they did because they were too uninformed to complete the survey form.

Putting the worst face on this experience, it might be argued that the responses of the officers, along with the non-responses of some of them, provide a kind of "projective 
test" evidence that the theory and practice of community policing may continue to face internal resistance from many rank and file members of the police bureau, at least for some time. In short, these results may not be particularly encouraging ones.

\section{DEMOGRAPHIC CHARACTERISTICS--RESIDENTS}

When survey data are collected, one often wonders if the persons who participated in the survey were representative of the population living in the area being studied. Since information about the actual residents was recorded in Housing Authority of Portland records, it was possible to compare characteristics of the sample to those of the area population.

The comparisons in Tables $\mathrm{V}$ and VI between the primary occupants on the HAP lease and the survey respondents reveal considerable similarity between the two groups, thus confidence can be placed in the representativeness of the baseline and post survey samples. Since this was a quasi-experiment without a control group and without any means to assure a stable target group, it was also important to determine if the baseline survey sample was similar to the post survey sample. The baseline and post survey responses to questions about race and sex of the person completing the survey are shown in Table VII. These data indicate that the racial and sexual distributions of people 
TABLE V

BASELINE AGE DATA

\begin{tabular}{ccccc}
\hline & $\begin{array}{c}\text { HAP Baseline Data } \\
\text { Primary Occupant } \\
(\underline{n}=93)\end{array}$ & $\begin{array}{c}\text { Baseline Survey } \\
\text { Respondent } \\
(\underline{\underline{n}}=77)\end{array}$ \\
\hline Age & $\#$ & $q$ & $\#$ & $q$ \\
\hline $16-21 \mathrm{yr}$. & 16 & 17 & 12 & 17 \\
$22-30 \mathrm{yr}$. & 13 & 14 & 17 & 24 \\
$31-39 \mathrm{yr}$. & 6 & 7 & 6 & 7 \\
$40-49 \mathrm{yr}$. & 18 & 20 & 9 & 11 \\
$50-59 \mathrm{yr}$. & 8 & 9 & 8 & 10 \\
$60 \mathrm{plus}$ & 32 & 34 & 25 & 31 \\
\hline
\end{tabular}

who were interviewed in the baseline and post survey were not significantly different.

\section{RESIDENT SURVEY}

The first two questions on the survey dealt with how long the respondent had lived at Iris Court and where he or she had lived previously. These questions were designed to be simple and easily answered in order to launch the interview in a positive direction. Survey answers are found in Appendix E. Some questions and answers are not explored 
TABLE VI

POST AGE DATA

\begin{tabular}{ccccc}
\hline & $\begin{array}{c}\text { HAP Post Survey Data } \\
\text { Primary Occupant } \\
(\underline{\underline{n}=95)}\end{array}$ & $\begin{array}{c}\text { Post Survey } \\
\text { Respondent } \\
(\underline{\underline{n}}=72)\end{array}$ \\
\hline Age & $\#$ & $q$ & $\#$ & $\%$ \\
\hline $16-21 \mathrm{yr}$. & 14 & 15 & 12 & 17 \\
$22-30 \mathrm{yr}$. & 13 & 14 & 17 & 24 \\
$31-39 \mathrm{yr}$. & 8 & 8 & 7 & 10 \\
$40-49 \mathrm{yr}$. & 20 & 21 & 6 & 8 \\
$50-59 \mathrm{yr}$. & 8 & 8 & 6 & 8 \\
$60 \mathrm{plus}$ & 32 & 34 & 24 & 33 \\
\hline
\end{tabular}

in the body of this dissertation, because they-were not directly germane to the project.

Question \#3 was an open-ended one: "What would you like to see done to improve life in this complex?" As with most open-ended questions, a variety of responses resulted, and these had to be coded prior to analysis. As with content analysis, the task was to reduce a wide variety of idiosyncratic items of information to a more limited set of responses. In summarizing the information from the baseline and post surveys, general groupings of answers that 
TABLE VII

SEX AND RACE DATA, BASELINE AND POST

\begin{tabular}{|c|c|c|c|c|}
\hline & \multicolumn{2}{|c|}{$\begin{array}{l}\text { Baseline } \\
(\underline{n}=80)\end{array}$} & \multicolumn{2}{|c|}{$\begin{array}{c}\text { Post } \\
(\underline{n}=72)\end{array}$} \\
\hline Sex & \# & $q$ & $\#$ & $q$ \\
\hline Male & 18 & 22 & 16 & 22 \\
\hline Female & 62 & 78 & 55 & 78 \\
\hline Race & \# & $q$ & $\#$ & \% \\
\hline Black & 50 & 63 & 45 & 63 \\
\hline White & 22 & 28 & 20 & 27 \\
\hline Native American & 4 & 5 & 4 & 6 \\
\hline Hispanic & 2 & 2 & 0 & 0 \\
\hline Unknown & 2 & 2 & 3 & 4 \\
\hline
\end{tabular}

were given by five or more respondents were identified.

Table VIII presents those answers.

From a police viewpoint, the most significant finding about the responses to question \#3 probably was the reduction in the number of persons who were concerned about getting rid of drugs and gangs. In the post survey, 28 of the respondents answered "keep drug deals down." This was a significant reduction from the $21 \%$ who answered about drugs 
TABLE VIII

TENANT SURVEY QUESTION $\# 3$, BASELINE AND POST

\begin{tabular}{lc}
\hline \multicolumn{1}{c}{ Concern } & 8 \\
\hline Baseline survey & 21 \\
Get rid of drugs and gangs & 13 \\
Don't know--nothing & 9 \\
Noise & 8 \\
Laundry problems (broken--poor location) & 7 \\
Doors (poor locks) & \\
Post survey & 18 \\
Nothing--all is fine & 7 \\
Unknown--don't know & 6 \\
Install speed bumps & 6 \\
Decrease noise & 5 \\
Quicker response to maintenance & \\
\hline
\end{tabular}

Note. Only concerns identified by five or more respondents were included.

and gangs in the baseline survey. There was no mention of gangs in the post survey responses. The respondent drop off in concern about this issue indicated that something apparently had been done about these problems. 
To assist in making sense of the results from the baseline and post surveys, the categories of human behavior issues and physical living issues were created. Question \#3 led to many more behavior issue responses in the baseline survey and many more physical living issues as responses in the post survey. For example, there were twenty answer categories in the baseline survey that pertained to human behavior and fourteen that had to do with such physical living issues such as more hot water, cement the basketball court, and better outside lighting. In the post survey, seven response categories pertained to human behavior, and twenty had to do with such physical living issues as requests for screen doors, more grass in the common areas, installation of carpets, add a swimming pool, repaint the inside of the apartments, and install speed bumps. In addition, the post survey human behavior-related responses seemed to take on a different tone. They included such recommendations as support groups for kids, parents should watch their children better, more attendance at resident meetings, and parenting classes. The baseline human behavior-related responses covered such topics as finding respect, being able to have children play outside safely, stop vandalism, and less quarreling among tenants. Since the post survey respondents were more concerned about physical livability issues such as more electrical outlets instead of the baseline response or concern that the 
police should not enter homes without a search warrant, one could surmise that public safety had been improved and, therefore, that other issues had come to the forefront. But since these are qualitative data, caution is in order in accepting this conclusion. Further, before any major victories for the Iris Court Community Policing Demonstration Project can be claimed, the respondents' appraisals must be reviewed in terms of the other survey questions as well as reported crime data and other relevant information. The data on fear of crime, quality of life and reported crime are reviewed below.

\section{FEAR OF CRIME}

Fear of crime has drawn much attention from academicians and police practitioners in recent years. The National Institute of Justice of the U.S. Department of Justice, the National Organization of Black Law Enforcement Executives (NOBLE), and academicians such as Wesley Skogan, Lawrence Sherman, Mary Ann Wycoff, Lee Brown, and James $Q$. Wilson have conducted studies that have addressed the role of fear of crime on criminal justice strategies and policies. Research has shown that fear of crime is often higher than reported crime levels and that fear can lead to neighborhood abandonment of common spaces and an increase in reported crime (Wilson \& Kelling, 1982). The situation at Iris court had created an atmosphere in which some residents 
saw themselves as prisoners within their own apartments, leading to their refusal to use the common space areas even though Housing Authority of Portland records showed a high occupancy rate in dwelling units. The following questions were used to explore fear of crime (see Appendix E):

\#17. How afraid are you when you go anywhere in the area after dark?

\#18. How afraid are you about being beaten up by a stranger?

\#19. How afraid are you about having someone break into your home while you are not at home?

\#20. How afraid are you about drug dealing in the area?

\#21. How afraid are you about gang activity in the area?

Three response categories were offered: "Not Afraid," Somewhat Afraid" and "Very Afraid." Table IX presents the respondents' fear of crime perceptions in the baseline and post surveys. Overall, the survey data indicated a reduction of fear of crime, although one should hasten to add that the decline in the percentages of residents who said they were somewhat or very afraid (65\% to 58\%) was not pronounced. One major data problem arose during the debriefing of the interviewers in both the baseline and post surveys. They reported that some elderly respondents answered that they were "Not Afraid" because "I never go out after dark, so why should I be afraid; anyone who goes out after dark gets what they deserve." As a result, these data 
TABLE IX

FEAR OF CRIME DATA, BASELINE AND POST

\begin{tabular}{lcccc}
\hline & \multicolumn{2}{c}{ Baseline } & \multicolumn{2}{c}{ Post } \\
\cline { 2 - 5 } Category & $\#$ & 8 & $\#$ & 8 \\
\hline Not afraid & 135 & 35 & 146 & 41 \\
Somewhat afraid & 97 & 25 & 90 & 25 \\
Very afraid & 162 & 40 & 118 & 33 \\
\hline
\end{tabular}

are more questionable as a demonstration of reduction in fear of crime. The comments by the elderly respondents demonstrate the powerful effect fear of crime has on the use of open spaces that have been designed within urban areas.

\section{QUALITY OF LIFE}

The quality of life concept sounds like a reasonable one, but it is more difficult to describe and measure. The following questions were used to probe the quality of life dimension (see Appendix E) :

\#6. Do you need help finding a job that you like doing?

\#9. What do you think of job opportunities in this area?

\#10. Do you need help finding good health care?

\#12. What do you think of health service in this area?

\#13. Do you need help with child care? 
\#15. What do you think of the physical condition of this complex?

These questions were intended to cover the areas of employment, health, and housing. Although perceptions of public safety are generally regarded as an element of the quality of life, they were not included because so much energy and time was spent insuring public safety as a component of reducing the fear of crime and reducing reported crime. Table $\mathrm{x}$ presents the responses to the above questions.

The employment responses indicated that skepticism about "job opportunities in this area" increased from the baseline to post period. The percentage of responses in the "very good" and "good" categories dropped by $12 \%$ overall; from $26 \%$ (baseline) to $14 \%$ (post). Opinions about job opportunities indicated that large numbers of persons have low hopes for improving their employment status. When they responded to the question about "needing help in finding a job that they like doing," an overwhelming number of persons fell into the "No" or "No Answer" categories ( $81 \%$ baseline and $79 \%$ post). The explanations for not needing help included "being retired," "going to school," "kids to care for," "getting married," "lost lots of jobs," and "can find work on my own." In summary, the responses show pessimistic perceptions about available employment and a "no thank you" response when offered help. These data suggest that many Iris court residents were persons who had tried and now had 
TABLE X

QUALITY OF IIFE DATA, BASELINE AND POST

\begin{tabular}{|c|c|c|c|c|}
\hline \multirow{2}{*}{ Question } & \multicolumn{2}{|c|}{ Baseline } & \multicolumn{2}{|c|}{ Post } \\
\hline & \# & $q$ & $\#$ & \% \\
\hline
\end{tabular}

EMPLOYMENT

Do you need help finding a job

that you like doing?

$\begin{array}{lllll}\text { Yes } & 15 & 19 & 15 & 21 \\ \text { No } & 62 & 81 & 45 & 63 \\ \text { No answer } & -- & -- & 12 & 16\end{array}$

What do you think of job

opportunities in this area?

Very good

Good

Fair

Poor

Very poor

No answer

$\begin{array}{rrrr}7 & 9 & 3 & 4 \\ 13 & 17 & 7 & 10 \\ 17 & 22 & 22 & 31 \\ 21 & 27 & 22 & 31 \\ 10 & 13 & 9 & 12 \\ 9 & 12 & 18 & 25\end{array}$

HEALTH

Do you need help finding good health care?

Yes

$\begin{array}{llll}9 & 12 & 14 & 19\end{array}$

No

$\begin{array}{llll}68 & 88 & 35 & 49\end{array}$

No answer

$23 \quad 32$ 
TABLE $X$

QUALITY OF LIFE DATA, BASELINE AND POST (continued)

\begin{tabular}{|c|c|c|c|c|}
\hline \multirow{2}{*}{ Question } & \multicolumn{2}{|c|}{ Baseline } & \multicolumn{2}{|c|}{ Post } \\
\hline & \# & 8 & * & 8 \\
\hline \multirow{2}{*}{\multicolumn{5}{|c|}{$\begin{array}{l}\text { HEALTH (Continued) } \\
\text { What do you think of health } \\
\text { service in this area? }\end{array}$}} \\
\hline & & & & \\
\hline Very good & 19 & 25 & 14 & 20 \\
\hline Good & 26 & 34 & 19 & 26 \\
\hline Fair & 23 & 30 & 18 & 25 \\
\hline Very poor & 1 & 1 & -- & - \\
\hline No answer & 5 & 6 & 14 & 18 \\
\hline \multirow{2}{*}{\multicolumn{5}{|c|}{$\begin{array}{l}\text { PHYSICAL CONDITION OF HOUSING } \\
\text { What do you think of the physical } \\
\text { condition of this complex? }\end{array}$}} \\
\hline & & & & \\
\hline Very good & 16 & 21 & 15 & 21 \\
\hline Good & 29 & 36 & 21 & 29 \\
\hline Fair & 27 & 35 & 30 & 42 \\
\hline Poor & 3 & 4 & 3 & 4 \\
\hline Very poor & 2 & 3 & 3 & 4 \\
\hline No answer & 9 & 12 & 18 & 25 \\
\hline
\end{tabular}


given up hope, or individuals that did not truly care to work because they did not even want help.

However, the issue of negative employment opinions must be pursued further, probing the impact of HAP regulations on a tenants' desire for employment. Under HAP regulations, a resident who gets a well-paying job may become disqualified for public housing but yet be unable to afford or manage stable housing outside the public housing system. This negative incentive is exacerbated by the regulation that rent must be increased once a person gets a job. Instead of viewing the residents of Iris court as lazy, it would be well to note the irony that getting a job may only serve to move them closer to poverty.

The initial, dubious attribution of laziness and disinterest in employment on the part of Iris court residents may be parallel to an incident in Liebow's (1967) report in Tally's Corner, where a truck driver becomes convinced that the idle black males on the corner are lazy when they refused to hop onto his truck for day labor jobs. Liebow reported that these men actually had reasonable explanations for not being interested in those jobs, which were low paying and short-term in nature. In addition, many of them had injuries or were physically debilitated, making this kind of work impossible. Those physical ailments were not always visible to casual observers. 
Overall, putting a State of Oregon Employment Specialist on-site twenty hours per week did not appear to change how people felt about job opportunities in the area, but it may be an error to take this as evidence that Iris court residents are lazy. The tenants have to consider whether a job will cause them to lose current benefits against the possibility that the job will provide enough for them to get out of the poverty cycle.

The health care quality of life data indicated a declining opinion about "health care in this area." The percentage of responses in the "very good" and "good" categories dropped $13 \%$ overall, from $59 \%$ (baseline) to $46 \%$ (post), during a period when the Iris court community Policing Demonstration Project had a community health nurse working on-site 32 hours per week. (For additional information about projects conducted by the nurse, see Appendix M.)

The responses regarding the physical condition of housing indicated a declining opinion about "the physical condition of this complex." The percentage of responses in the "very good" and "good" categories dropped $7 \%$ overall; from $57 \%$ (baseline) to $50 \%$ (post). This decline was not large, and the post data were offset by a $7 \%$ increase in the "fair" response. While there were no special projects and programs to change or improve the actual physical condition 
of the apartments, some funds were expended on improving the grounds and playground equipment at Iris court.

In order to examine the overall quality of life issue rather than specific areas such as public safety, housing, employment or health, the following question was asked early in the interview: since last summer, has this complex become better, gotten worst or stayed about the same?" The responses are indicated in Table XI.

The increase of $12 \%$ in the "better" category shows improvement with regard to the number of respondents who felt that the quality of life generally improved at Iris court. This improvement occurred despite the declining opinions about job chances, health care and physical

TABLE XI

TENANT SURVEY QUESTION \#4, BASELINE AND POST

\begin{tabular}{lcccc}
\hline & \multicolumn{2}{c}{ Baseline } & \multicolumn{2}{c}{ Post } \\
\cline { 2 - 5 } Response & $\#$ & $\%$ & $\#$ & $\%$ \\
\hline Better & 41 & 53 & 47 & 65 \\
Worse & 14 & 18 & 8 & 11 \\
Same & 22 & 29 & 13 & 18 \\
Unknown & -- & -- & 4 & 6 \\
\hline
\end{tabular}


conditions. This interpretation was complicated, because it was not possible to identify how specific persons responded during the baseline and post surveys. Even more important, it was not possible to determine which programs or strategies influenced the increase in positive attitudes about improved quality of life.

One possibility is that for a resident of low-income public housing, fear of crime and reported crime have a much greater impact on how that person feels about quality of life than feelings about jobs, health care and housing. This conjecture can be generalized beyond low-income public housing, because reduced fear of crime may lead to better feelings, even when job, health care, and physical conditions do not improve. In summary, measurement of quality of life was difficult task. The post data can be interpreted as showing positive changes, but it would have been helpful if additional quality of life information had been collected. The data that follow about reported crime in the Iris court area are much clearer and direct.

\section{ANALYSIS OF CRIME}

As noted earlier, the clearest of the three project goals was reduction of reported crime. Data on Part I and Part II crimes for the project area were generated from the Portland Police Data System (PPDS). The time period for the baseline data was April 1, 1989, through March 31, 1990, 
while the time period for the post data was April 1, 1990 through March 31, 1991. The crime data for the Iris court area are shown in Table XII and on Figure 5.

Because many variables might have influenced reported crime during this two-year period, the Iris court area data were compared with those from the entire North Precinct area (see Table XIII) and for the entire city of Portland for the same time periods (see Table XIV).

TABLE XII

REPORTED CRIMES FOR THE IRIS COURT AREA, BASELINE AND POST

\begin{tabular}{lccc}
\hline \multicolumn{1}{c}{ Type } & Baseline & Post & \% change \\
\hline Part I \& II & 208 & 94 & -55 \\
Specific offenses: & 2 & 2 & \\
Rape & 6 & 4 & \\
Robbery & 26 & 10 & \\
Aggravated assault & 30 & 17 & \\
Simple assault & 9 & 7 & \\
Residential burglary & 36 & 4 \\
Drug abuse & 32 & 15 \\
Gang activity & & & \\
\hline
\end{tabular}

a Represents serious and/or violent personal and property crimes which likely leave a lasting and traumatic impression on the victim(s) and their immediate family, friends and neighbors. 


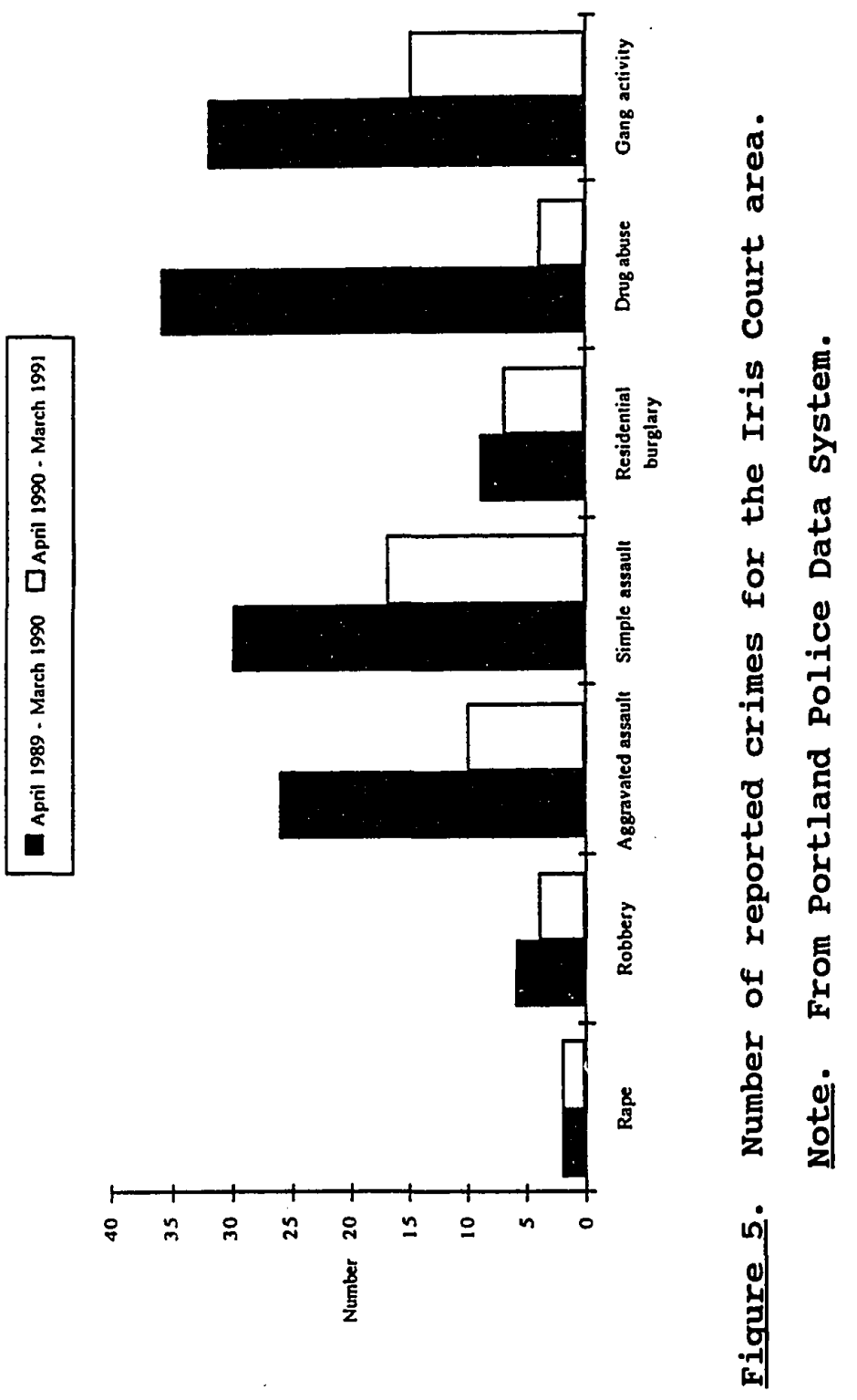


TABLE XIII

REPORTED CRIMES FOR THE NORTH PRECINCT, BASELINE AND POST

\begin{tabular}{lrrc}
\multicolumn{1}{c}{ Type } & Baseline & Post & \& Change \\
\hline Part I \& II & 26,678 & 24,177 & -7 \\
Specific offenses: & & & \\
Rape & 187 & 168 & \\
Robbery & 1039 & 978 & \\
Aggravated assault & 2182 & 2087 & \\
Simple assault & 2418 & 2276 & \\
Residential burglary & 2928 & 2067 & \\
Drug abuse & 1469 & 861 \\
Gang activity & 1715 & 1557 \\
\hline
\end{tabular}

a Represents serious and/or violent personal and property crimes which likely leave a lasting and traumatic impression on the victim(s) and their immediate family, friends and neighbors.

The $55 \%$ reduction of reported crime within the Iris Court area was striking. This success indicator was unmatched by any other one involved in this evaluation. The Part I and II crimes used to measure crime trends in this project were the serious and/or violent personal and property crimes which often leave a lasting and traumatic impression on the victim(s) and their immediate family, friends and neighbors. The $55 \%$ reduction in crime suggests that life became different at Iris court and that the changes had a positive effect upon crime levels. 
TABLE XIV

REPORTED CRIMES FOR THE CITY OF PORTLAND, BASELINE AND POST

\begin{tabular}{lrrr}
\hline \multicolumn{1}{c}{ Type } & Baseline & \multicolumn{1}{c}{ Post } & \& Change \\
\hline Part I \& II & 86,924 & 83,407 & -4 \\
Specific offenses: & & & \\
Rape & 451 & 426 & \\
Robbery & 2,466 & 2,685 & \\
Aggravated assault & 2,182 & 2,087 & \\
Simple assault & 2,418 & 2,276 \\
Residential burglary & 2,928 & 2,067 \\
Drug abuse & 1,469 & 861 \\
Gang activity & 1,715 & 1,557 \\
\hline
\end{tabular}

a Represents serious and/or violent personal and property crimes which likely leave a lasting and traumatic impression on the victim(s) and their immediate family, friends and neighbors.

However, a word of caution is required when reviewing reported crime data. People do not always notify the police; consequently, reported offenses are only an indicator of crime levels, not an absolute measure of total crime. For example, in 1989 the Portland Police Bureau implemented a citizen "mail-in" crime-reporting program for thefts from motor vehicles and theft of motor vehicle parts and accessories. This was followed by a decrease in reported larceny within the city. Perhaps larceny really did decline, but it is also quite possible that many persons 
failed to mail in reports of crime because they found it more difficult to fill out the forms than when someone else listened and wrote the reports. Or perhaps the ever-changing insurance practices such as rising deductibles and insurance costs contributed to the reduced reporting. In summary, even though one must treat the crime data with caution, the Iris Court area reductions were impressive. They provide hope and reflect positively on the Iris Court Community Policing Demonstration Project.

\section{CALLS-FOR-SERVICE}

An often asked question about community policing has to do with the impact of this philosophy on calls-for-service. One view is that community policing efforts will spur a jump in calls-for-service because people will turn to the police more often than in the past (Trojanowicz \& Bucqueroux, 1990). Within the Portland Police Bureau, however, there is the expectation that once community policing is fully implemented, calls-for-service will decrease because the police will be solving problems at locations that traditionally have generated many repeat calls-for-service. Currently the police may simply write reports, or incidents are coded-off (classified as no written report necessary) without a solution being found to the situation that caused them to be called to the scene in the first place. 
In order to examine this matter, calls-for-service within the Iris Court Community Policing Demonstration Project area were reviewed (see Table XV). As a result of complications with the computer tapes at the Bureau of Emergency Communications, the information only covers January 1990 through April 30, 1990, and January 1, 1991, through April 30, 1991. All other baseline and post data cover April 1, 1989, through March 31, 1990, and April 1, 1990, through March 31, 1991. These limited data did not provide the total picture, but they did serve as an indicator of the results of community policing.

This reduction in calls-for-service was encouraging and fell within the long-range expectations of the Portland Police Bureau, but other factors must be considered. The

TABLE XV

CALLS-FOR-SERVICE (ALL TYPES), IRIS COURT AREA

\begin{tabular}{ccc}
$\begin{array}{c}\text { January-April } \\
1990\end{array}$ & $\begin{array}{c}\text { January-April } \\
1991\end{array}$ & \& Change \\
\hline 168 & 131 & -22 \\
\hline
\end{tabular}

Note. Due to complications with the City of Portland's Bureau of Emergency Communications tapes, only data for the above periods were available (rather than baseline data from April 1, 1989, through March 31, 1990, and post data from April 1, 1990, through March 31, 1991). 
increased presence of police officers within the complex and surrounding area may have resulted in calls-for-service being completed outside the normal channels of 911, thus calls that were handled when someone stopped to visit an officer at the contact office did not appear in the official reports.

An additional consideration is that calls-for-service can be influenced by many other factors. The number of available telephones within a given area can affect the number of calls. Also, the attitude, ability and skill of the actual call takers at 911 (Bureau of Emergency Communication) can influence the number of calls-for-service. For example, the Bureau of Emergency Communication data do not include operator hang-ups or refusal of the operators to create a police call-for-service because they had determined that the situation did not warrant a response. In other words, the tape does not include lost calls, terminated calls or calls otherwise closed at the operator level. Calls-for-service can be manipulated by procedures, or the calls may be lost as a result of equipment failure. In conclusion, caution is advised when reviewing calls-for-service data.

This chapter has been concerned with the evidence on the impact of the Iris court project. clearly, much of that evidence was mixed, although some of it was moderately positive. In particular, crime apparently was reduced 
through project efforts. The concluding chapter discusses

recommendations and conclusions to be drawn from this effort. 
CHAPTER VIII

CONCLUSIONS

PROCESS

The process and outcome evaluations of the Iris court project reported in Chapters $\mathrm{V}$ and VI described the goals for community policing and implementation by the Portland Police Bureau. The project goals statement served as a useful guide to implementation activities. By constantly asking if the planned activity was meeting the goals of partnership, empowerment, problem solving, accountability, and service orientation, the project remained focused, and the work group members were not diverted to pursuing goals which conflicted with those of other members or the desires of the customers, that is, the Iris court residents.

The model for conducting community policing that was followed in the Iris court project does not appear to be limited to a particular neighborhood situation, rather it could be adapted to a variety of urban neighborhoods and communities. The procedures could be modified to local conditions and utilized to pursue community policing goals. 
OUTCOME

The evaluation of the Iris Court Community Policing Demonstration Project was conducted to assess whether community policing would have a measurable effect on public safety. The dependent variables were quality of life, fear of crime and reported crime. The implementation of various community policing strategies can be judged to have been successful if reported crime dropped, the fear of crime was reduced, and the quality of life was improved. It is evident from the data that the Iris Court Community Policing Project was at least moderately successful. Reported crime dropped, the fear of crime was reduced, and there were mixed indications that the quality of life for the complex was improved.

The most striking supportive finding was the 558 decrease in reported crime. Although crime within the city of Portland also decreased during the study period, the Iris court reduction was much more pronounced. This result was even more significant in light of the high levels of crime and violence within Iris court that had existed prior to the community policing effort. Breaking this cycle by such a wide margin was unexpected.

The fear of crime data were not as conclusive, but there was an increase in the number of residents reporting themselves as "not afraid." However, the finding is somewhat suspect in that some elderly respondents reported 
that they were "not afraid" because they "never go out after dark." Quality of life was the most difficult goal to assess, but overall more people indicated that life in the complex got better during the post year.

These conclusions require several qualifications. First and most obvious, the data were limited to a one-year study period. Without a longer period, there is no certainty that a lasting impact was achieved. But since the city of Portland and the Portland Police Bureau have many community crime problems to confront, there was not time for a prolonged study of these various community policing strategies.

Second, given the lack of a control group, there is no way to prove that the improvements in Iris court can be attributed solely or even partially to the strategies of the demonstration project. Perhaps improvements at Iris court would also have occurred if some tragic murders or some other "trigger incidents" had taken place at the complex. Even more important, it is conceivable that similar changes occurred in some other unidentified high crime areas in Portland, even without any community policing intervention. Still, indicators point to the strategies of community policing as the catalyst for change. 
RECOMMENDATIONS

There are a number of recommendations that flow from this research, some having to do with future research studies and some with community policing ventures to be undertaken in Portland or elsewhere in the future. First, a one-year study period is not long enough. The Iris court Community Policing Demonstration Project should continue, and additional data should be gathered. Tenant turnover continues at Iris court. While many residents have seen the efforts of the demonstration project as positive and have joined with the various agencies to make the project successful, what future tenants will do is unclear. For example, will the tenant communication network be maintained as different families move into the complex?

A second research question is whether social service agencies will maintain their standards and levels of output once Iris court becomes "old news" and the complex is not seen as a community in crisis. Also, will community policing become institutionalized at Iris Court? Will future police officers work as hard at problem solving and partnership building once the area is no longer a demonstration project? In other words, will the entire project success be a case of the Hawthorne effect or will the effects be lasting? These and other questions can only be answered with a long-term evaluation effort which would 
strengthen the knowledge about the effectiveness of what has been accomplished to date.

It is also recommended that future evaluations be done by persons outside the Portland Police Bureau. Internal evaluations can be very cost-effective and honest, but they sometimes fail to ask difficult questions and may produce questionable data. This comment is not meant to be an attack upon this evaluation, it is instead a recommendation for future work. Clearly, many options for additional analysis exist and should be explored in any future evaluation of this project. For example, more time could be spent on determining the quality of life dimensions that are most important to this population. This study utilized some fairly standard variables because of various pressures to gather baseline data and implement the strategies, but an outside evaluator who could perhaps move more slowly and could determine what indicators fit the Iris court population.

The Portland Police Bureau should continue the implementation of community policing. When police officers want to know if community policing was successful at Iris court, this researcher can simply ask them if they respond to as many calls-for-service there, compared to the workload prior to the use of community policing strategies. And when Portland Police officers do go to Iris court, the tenants are helpful and open. The children are friendly and 
citizen-police contacts are less stressful than they were prior to community policing. The altered attitudes of tenants were demonstrated when this researcher was promoted to Police Captain in April of 1991. Over twenty-five Iris Court tenants traveled to the Justice center to observe and celebrate the event. For several of them it was the first time they had ever visited a police station. For several others it was the first time they had entered a police facility without being in handcuffs.

The evaluation data and the statistical review may not be as strong as many researchers would desire, but this researcher is personally convinced that conditions and attitudes at Iris court changed for the better. Community policing is a successful revolution in law enforcement which should be supported and continued. 
REFERENCES CITED AND ADDITIONAL LITERATURE

REFERENCES CITED

Allen-Bond, M. (1984). Policing Japan. Law nnd order, $\underline{5}$ 46-52.

Alpert, G. P., \& Dunham, R. G. (1989). Community policing. In R. G. Dunham \& G. P. Alpert, (Eds.), Critical issues in policing (pp. 407-24). Prospect Heights, IL: Waveland Press.

Andrews, F. M. (Ed.). (1986). Research on the quality of life. Ann Arbor, MI: The University of Michigan.

Angell, J. (1971). Toward an alternative to the classic police organizational arrangements: A democratic model. Criminology, $9(2-3), 185-206$.

Babbie, E. (1989). The practice of social research (5th ed.). Monterey, CA: Wadsworth.

Bayley, D. H. (1991). Forces of order: Policing modern Japan. Los Angeles: University of California Press.

Becker, C. B. (1983). Social control of crime in Japan. Police Journal, $3,269-75$.

Braithwaite, J. (1989) . Crime, shame and reintegration. Cambridge, University Press.

Brown, L. P. (1971) . Typology: Orientation of policecommunity relations programs. The Police chief, 4 , 16-20.

Brown, L. P. (Ed.). (1976) . Neighborhood team policing: The Multnomah county experience. Portland, OR: Multnomah County Sheriff's office.

Brown, L. P. (1985). Police-community power sharing. In W. Geller (Ed.), Police leadership in America: Crisis and opportunity (pp. 70-83). New York: Praeger. 
Bureau of Justice Assistance. (1991). Community partnerships: A community policing model for drug demand reduction. Grant \#91-DD-CX-001 (S-1). Washington, DC: Author.

Christopher, พ. (1991). Summary report. Los Angeles: Independent Commission on the Los Angeles Police Department.

Davis, R. C. (1985). Organizing the community for improved policing. In W. A. Geller (Ed.), Police leadership in America: Crisis and opportunity (pp. 84-95). New York: American Bar Foundation.

Eck, J. E., \& Spelman, W. (1989). Problem solving: Problem-oriented policing in Newport News. In R. G. Dunham \& G. P. Alpert. Critical issues in policing (pp. 425-31). Prospect Heights, IL: Waveland Press.

Fink, J., \& Sealy, L. G. (1974). The community and the police: Conflict or cooperation? New York: John Wiley.

Gabor, I. R., \& Low, C. (1973). The police role in the community. Criminology, 4, 383-414.

Geller, W. A. (Ed.). (1985). Police leadership in America: crisis and opportunity. New York: Praeger.

Gibbons, D. C. (1979). The criminological enterprise. Englewood Cliffs, NJ: Prentice-Hall.

Gibbons, D. C. (1992). Society, crime, and criminal behavior. Englewood Cliffs, NJ: Prentice Hall.

Gibbons, D. C., Thimn, J., Yospe, F., \& Blake, G. Jr. (1977). Criminal justice planning: An introduction. Englewood cliffs, NJ: Prentice Hall.

Goldstein, H. (1977). Policing a free society. Cambridge, MA: Ballinger.

Goldstein, H. (1990). Problem oriented policing. New York: McGraw-Hill.

Greene, J. R., \& Taylor, R. B. (1988). Community-based policing and foot patrol: Issues of theory and evaluation. In J. R. Greene \& S. D. Mastrofski (Eds.), Community policing: Rhetoric or reality (pp. 195-223). New York: Praeger. 
Johnson, T. A., Misner, G. E., \& Brown, I. P. (1981). The police and society: An environment for collaboration and confrontation. Englewood Cliffs, NJ: Prentice-Hall.

Jolin, A. I., \& Gibbons, D. C. (1984). Policing the police: The Portland experience. Journal of Police Science and Administration, 12(3), 315-322.

Kelling, G. L. (1988). Police and communities: The quiet revolution. Perspectives on policing (Report No. 1). Washington, DC: National Institute of Justice.

Kelling, G. L., \& Moore, M. H. (1988). From political to reform to community: The evolving strategy of police. In J. R. Greene \& S. D. Mastrofski (Eds.), Community policing: Rhetoric or reality (pp. 3-25). New York: Praeger.

Kidder, I. H. (1981). Research methods in social relations (4th ed.). New York: Holt, Rinehart and winston.

Koller, K. (1990). Working the beat: The Edmonton neighborhood foot patrol. Edmonton, Alberta, Canada: co-op Press Ltd.

Levitan, S. A. (1990). Programs in aid of the poor (6th ed.) Baltimore: Johns Hopkins University Press.

Liebow, E. (1967). Tally's corner. Boston: Little-Brown.

Maccoll, E. K. (1979). The growth of a city: Power and politics in Portland, Oregon--1915 to 1950. Portland, OR: The Georgian Press.

Manning, P. K. (1984). Community policing. American Journal of Police, $3(2), 205-27$.

Manning, P. K. (1988). Community policing as a drama of control. In J. R. Greene \& S. D. Mastrofski (Eds.), Community policing: Rhetoric or reality (pp. 27-45). New York: Praeger.

Manning, P. K., \& Van Maanen, J. (1978). Policing: A view from the street. Santa Monica, CA: Goodyear Publishing Company.

Mayhall, P. D. (1985). Police-community relations and the administration of justice. New York: John Wiley and Sons. 
Monkkonen, E. H. (1981). Police in urban America: 1860-1920. Cambridge, MA: Cambridge University Press.

Moore, M. H., Trojanowicz, R. C.. \& Kelling, G. L. (1988). Crime and policing. Perspectives on policing (Report No. 2). Washington, DC: National Institute of Justice.

Moser, C. A., \& Kalton, G. (1972). Survey methods in social investigation. New York: Basic Books.

Murphy, C. (1988). The Development, impact and implications of community policing in Canada. In J. R. Greene \& S. D. Mastrofski (Eds.), Community policing: Rhetoric or reality (pp 177-89). New York: Praeger.

Newman, 0. (1972). Defensible space: Crime prevention through urban design. New York: Macmillan.

O'Hara, R. (Ed.) (1982). Portland police: Past and present--130-Year Commemorative Issue. Visalia, CA: Josten's Publications.

Pate, A. M. , Annan, S. O. (1989, November). The Baltimore community policing experiment. Paper presented at the 41 st Annual Meeting of the American Society of Criminology, Reno.

Portland Police Bureau. (1971). Annual report. Portland, OR: Author.

Portland Police Bureau. (1972). Annual report. Portland, OR: Author.

Portland Police Bureau. (1990). Portland Police Bureau community policing transition plan. Portland, OR: Author.

Poyner, B. (1991). Crime free housing. New York: oxford Press.

Purdy, R. F. (1947). The rose city of the world: Portland, oregon. Portland, OR: Binfords and Mort.

Radelet, L. A., \& Reed, H. C. (1986). The police and the community (4th sd.). New York: Macmillan.

Rosenbaum, D. (1987). The theory and research behind neighborhood watch. Crime and Delinquency, 33(1), 103-134. 
Sanders, R. (1991). Glimpses from the past: The housing authority of Portland. Portland, OR: Housing Authority of Portland.

Schwartz, A. I., \& Clarren, S. N. (1977). The Cincinnati team policing experiment: A summary report. Washington, DC: The Urban Institute.

Sherman, L. W. (1983). Patrol strategies for police. In J. Q. Wilson (Ed.), Crime and public policy. San Francisco: Institute for Contemporary studies Press.

Sherman, L. W., Milton, C., \& Kelly, T. (1973). Team policing: Seven case studies. Washington, DC: Police Foundation.

Skogan, W. G. (1990). Disorder and decline. New York: Macmillan.

Skogan, W. G. \& Maxfield, M. (1981). Coping with crime. Beverly Hills, CA: Sage Publications.

Skolnick, J. H. (1966). Justice without trial: Law enforcement in a democratic society. New York: John wiley.

Skolnick, J. H., \& Bayley, D. H. (1986). The new blue line: Police innovation in six American cities. New York: The Free Press.

Sparrow, M. K., Moore, M. H., \& Kennedy, D. M. (1990). Beyond nine-one-one: A new era for policing. New York: Basic Books.

Taft, P. B., Jr. (1986). Fighting fear: The Baltimore County C.O.P.E. Project. Washington, DC: Police Executive Research Forum.

Trojanowicz, R. C., \& Bucqueraux, B. (1990). Community policing: A contemporary perspective. Cincinnati, $\mathrm{OH}$ : Anderson Publishing Co.

Unis, J. S. (1981). Trouble in river city: An analysis of an urban vice probe. Unpublished doctoral dissertation, Portland state University, Portland, oregon.

Walker, S. (1977). A critical history of police reform. Lexington, MA: Lexington Books.

Walker, S. (1985). Sense and nonsense about crime: A policy quide. Belmont, CA: Brooks-Cole Publishing. 
Weatheritt, M. (1987). Community policing now. In P. Willmott (Ed.), Policing and the community (pp. 7-20). London: Policy Studies Institute.

Wilson, J. Q. (1968). Varieties of police behavior. Cambridge, MA: Harvard University Press.

Wilson, J. Q. (1985). Thinking about crime (rev. ed.). New York: Vintage Books.

Wilson, J. Q., \& Herrnstein, R. J. (1985). Crime and human nature. New York: Simon and Schuster.

Wilson, J. Q., \& Kelling, G. L. (1982, March). Broken windows. Atlantic Monthly, pp. 29-38.

Wilson, J. Q., \& Kelling, G. L. (1989, February) . Making neighborhoods safe. Atlantic Monthly, pp. 46-52.

Wilson, O. W. (1957). Park on police. Springfield, IL: C. c. Thomas.

Wilson, 0. W. (1977). Police administration. New York: MCGraw-Hill.

ADDITIONAL LITERATURE

Abbott, c. (1983). Portland: Planning, politics and growth in a twentieth century city. Lincoln, NE: University of Nebraska Press.

Alkins, M. C., \& Solmon, L. C. (1983). The costs of evaluation. Beverly Hills: Sage Publications.

Ames, W. (1981). Police and community in Japan. Berkeley: University of California Press.

Bayley, D. H. (1985). Patterns of policing: A comparative international analysis. New Brunswick, NY: Rutgers University Press.

Bennett, G. (1987). Crimewarps: The future of crime in America. Garden City, NY: Doubleday Press.

Brown, L. P., \& Wycoff, M. A. (1987). Policing Houston: Reducing fear and improving service. Crime and Delinquency, 33, 71-89. 
Brown, L. P. (1989). Community policing: A practical guide for police officials. Perspectives on policing, (Report No. 12). Washington, DC: National Institute of Justice.

Brown, L. P. (1991). Responding to a changing environment. The Police Chief, March, 20-23.

Brown, R. M. (1991). No duty to retreat. New York: Oxford University Press.

Cameron, N. (1990). The police and crime control: Effectiveness, community policing, and legal change. Criminal Law Forum, 3 , 459-476.

Carte, G. E., \& Carte, E. H. (1975). Police reform in the United States: The era of August Vollmer, 1905-1932. Berkeley, CA: University of California Press.

Cordner, G. W. (1978). A problem-oriented approach to community-oriented policing. In J. R. Greene \& S. D. Mastrofski (Eds.), Community policing: Rhetoric or reality (pp. 135-52). New York: Praeger.

Cordner, G. W. (1986). Fear of crime and the police: An evaluation of a fear-reduction strategy. Journal of Police Science and Administration, 14, 371-379.

Cordner, G. W., \& Trojanowicz, R. C. (1992). Patrol. In G. W. Cordner \& D. C. Hale (Eds.), what works in policing: operations and administration examined. Cincinnati, OH: Anderson Publishing Co.

Cunningham, w. C., Strauchs, J. J., \& Van Meter, C. W. (1991). Private security: Patterns and trends. Washington, DC: National Institute of Justice.

Currie, E. (1985). Confronting crime: An American challenge. New York: Pantheon Books.

David, J., Cowan, L., Renner, E., More, T. (1976). Police community relations: A process, not a product. The Police Chief, $3,16-18$.

Eisenberg, T., Glickman, A. S., \& Fosen, R. H. (1969). Action for change in police-community behaviors. Crime and Delinquency, $\underline{3}$, 393-406.

Englert, R. (1990). Safety action team. FBI Law Enforcement Bulletin, 59(10), 3 . 
Farrell, M. J. (1988). The development of the community patrol officer program: Community-oriented policing in the New York City Police Department. In J. R. Greene \& S. D. Mastrofski (Eds.), Community policing: Rhetoric or reality (pp. 73-88). New York: Praeger.

Decker, S. H. (1981). Citizen attitude toward the police. Journal of Police Science and Administration, 2, 80-87.

Deters, G. A. (1978). Changing attitudes in policecommunity relations and the Warren court effect. Law and Order, $1,76-80$.

Deters, G. , \& Del Re, G. (1977). No-fault policing: Generating community interest to share prevention responsibility. The Police Chief, 4, 56-58.

Fyfe, J. J. (Ed.). (1989). Police practice in the 90's: Key management issues. Washington, DC: International city Management Association.

Germann, A. C. (1969). Community policing: An assessment. The Journal of Criminal Law, criminology and Police Science, 1, 89-96.

Goldstein, H. (1979). Improving policing: A problemoriented approach. Crime and Delinquency, $2,236-58$.

Greenberg, R. (1990). Let's take back our streets. Chicago, IL: Contemporary Books.

Greene, J. R., \& Mastrofski, S. D. (Eds.). (1988). Community policing: Rhetoric or reality. New York: Praeger.

Greene, J. R. (1989). Police and community relations: Where have we been and where are we going? In $R$. $G$. Dunham \& G. P. Alpert (Eds.), Critical Issues in Policing (pp. 349-68). Prospect Heights, IL: Waveland Press.

Greene, J. R. (1989). Police officer job satisfaction and community perception: Implications for communityoriented policing. Journal of Research in Crime and Delinquency, $\underline{2}, 168-183$.

Guyot, D. (1979). Bending granite: Attempts to change the rank structure of American police departments. Journal of Police Science and Administration. September, 53-84. 
Hanewicz, W. B., Fransway, I. M., \& O'Neill, M. W. (1982). Improving the linkages between community mental health and the police. Journal of Police Science and Administration, $\underline{2}$, 218-23.

Hartman, F. X. (Ed.). (1988). Debating the evolution of American policing. Perspectives on policing (Report No. 5). Washington, DC: National Institute of Justice.

Hartman, F. X. , Brown, I. P. \& Stephens, D. (1988). Community policing: Would you know it if you saw it? East Lansing, MI: National Neighborhood Foot Patrol Center, School of Criminal Justice, Michigan state University.

Herman, J. L., Morris, L. L., \& Fitz-Gibbon, C. T. (1987). Evaluator's handbook. Newbury Park, CA: Sage.

Institute for Law and Justice. (1990). Organization analysis of the Portland Police Bureau. Alexandria, VA: Author.

Kelling, G. L. (1985). Order maintenance, the quality of urban life, and the police: A line of argument. In $w$. Geller (Ed.), Police leadership in America: Crisis and opportunity (pp. 296-308). New York: Praeger.

Kelling, G. L., \& Stewart, J. K. (1990). Neighborhoods and police: The maintenance of civil authority. Criminal Law Forum, 3 , 459-476.

King, J., Morris, L. L., \& Fitz-Gibbon, C. T. (1987). How to assess program implementation. Newbury Park, CA: Sage.

Klein, M. W., \& Teilmann, K. S. (Eds.). (1980). Handbook of criminal justice evaluation. Beverly Hills: Sage.

Klockars, C. B. (1983). Thinking about police. New York: McGraw-Hill.

Klockars, C. B. (1985). Order maintenance, the quality of urban life, and police: A different line of argument. In W. A. Geller (Ed.), Police leadership in America: Crisis and opportunity (pp. 309-321). New York: Praeger.

Larson, R. C. (1990). Rapid response and community policing: Are they really in conflict. East Lansing, MI: National Center for Community Policing, school of Criminal Justice, Michigan State university. 
Levitan, S. A. , \& Shapiro, I. (1987) - Working but poor: America's contradiction. Baltimore: Johns Hopkins University Press.

Loehr, D. J., \& Quinn, P. K. (1976). Community oriented policing. Law and order, $\underline{3}, 78-81$.

McGahey, R. M. (1986). Economic conditions: Neighborhood organization and urban crime. In A. J. Reiss, Jr. \& M. Tonry (Eds.), Communities and crime (pp. 231-270). Chicago: The University of Chicago Press.

Mastrofski, S. (1988). Community policing as reform: A cautionary tale. In J. R. Greene \& S. D. Mastrofski (Eds.), Community policing: Rhetoric or reality (pp. 47-67). New York: Praeger.

Miyazawa, S. (1992). Policing in Japan: A study on making crime. Albany, NY: State University of New York Press.

Oettmeier, T. N., \& Brown, L. P. (1988). Developing a neighborhood oriented policing style. In J. R. Greene \& S. D. Mastrofski (Eds.), Community policing: Rhetoric or reality (pp. 121-134). New York: Praeger.

Patton, M. Q. (1987). How to use qualitative methods in evaluation. Newbury Park, CA: Sage.

Police Foundation. (1981). The Newark Foot Patrol Experiment. Washington, DC: Author.

Reiss, A. (1985). Policing a city's central district: The Oakland story. Washington, DC: U.S. Department of Justice.

Riechers, L. M. , \& Roberg, R. R. (1990) . Community policing: A critical review of underlying assumptions. Journal of Police Science and Administration, 17(2), 105-114.

Sherman, L. W. (1986). Policing communities: What works? In A. J. Reiss, Jr. \& M. Tonry (Eds.), Communities and crime, (Vol. 8, pp. 343-386). Chicago: The University of Chicago Press.

Skogan, w. G. (1988). Community organizations and crime. In M. Tonry \& N. Morris (Eds.), Crime and justice: A review of research (Vol. 10, pp. 39-78). Chicago: The University of Chicago Press. 
Skolnick, J. H. (1988). Theme and variation in community policing. In M. Tonry \& N. Morris (Eds.), Crime and justice: A review of research (Vol. 10, pp. 1-37). Chicago: The University of Chicago Press.

Slovak, J. S. (1986) . Styles of urban policing: organization, environment, and police styles in selected American cities. New York: New York University Press.

Sparrow, M. K. (1988). Implementing community policing: Perspectives on policing (Report No. 9). Washington, DC: National Institute of Justice.

Smith, R. L., \& Taylor, R. W. (1985). A return to neighborhood policing: The Tampa, Florida experience. The Police chief, 12, 39-44.

Stewart, J. K. (1985). Research and the police administrator: Working smarter, not harder. In $w$. Geller (Ed.), Police leadership in America: Crisis and opportunity (pp. 371-382). New York: Praeger.

Tafoya, w. L. (1990). The future of policing. FBI Law Enforcement Bulletin, 1, 13-17.

Trojanowicz, R. C. (1986). Evaluating a neighborhood foot patrol program: The Flint, Michigan project. In $D$. Rosenbaum (Ed.), Crime prevention: Does it work? Beverly Hill, CA: Sage.

Trojanowicz, R. C., \& Carter, D. (1988). The philosophy and role of community policing. East Lansing, MI: National Neighborhood Foot Patrol Center, School of Criminal Justice, Michigan State University.

Trojanowicz, R. C., \& Moore, M. H. (1988). The meaning of community in community policing. East Lansing, MI: National Neighborhood Foot Patrol Center, School of Criminal Justice, Michigan State University.

walker, S. (1989). Broken windows and fractured history: The use and misuse of history in recent police patrol analysis. In R. G. Dunham \& G. P. Alpert (Eds.), Critical issues in policing (pp. 382-394). Prospect Heights, IL: Waveland Press.

Wasserman, R., \& Moore, M. H. (1988). Values in policing. Perspectives on policing (Report No. 8). Washington, DC: National Institute of Justice. 
Weatheritt, M. (1988). Community policing: Rhetoric or reality? In J. R. Greene \& S. D. Mastrofski, (Eds.), Community policing: Rhetoric or reality (pp. 153-75). New York: Praeger.

Webber, A. M. (1991). Crime and management: An interview with NYC Police Commissioner Lee P. Brown. Harvard Business Review, May-June, 111-126.

Whitaker, G. P. (1980). Co-production: Citizen participation in service delivery. Public Administration Review, 3 , 240-46.

Williams, H., \& Murphy, P. V. (1988). The evolving strategy of police: A minority view. Perspectives on policing (Report No. 13). Washington, DC: National Institute of Justice.

Wycoff, M. A. (1988). The benefits of community policing: Evidence and conjecture. In J. R. Greene \& S. D. Mastrofski (Eds.), Community policing: Rhetoric or reality (pp. 103-20). New York: Praeger.

Yin, R. (1986). Community crime prevention: A synthesis of eleven evaluations. In D. Rosenbaum (Ed.), Community crime prevention: Does it work? Beverly Hills, CA: Sage. 
APPENDIX A

\section{MAP OF IRIS COURT COMPLEX}




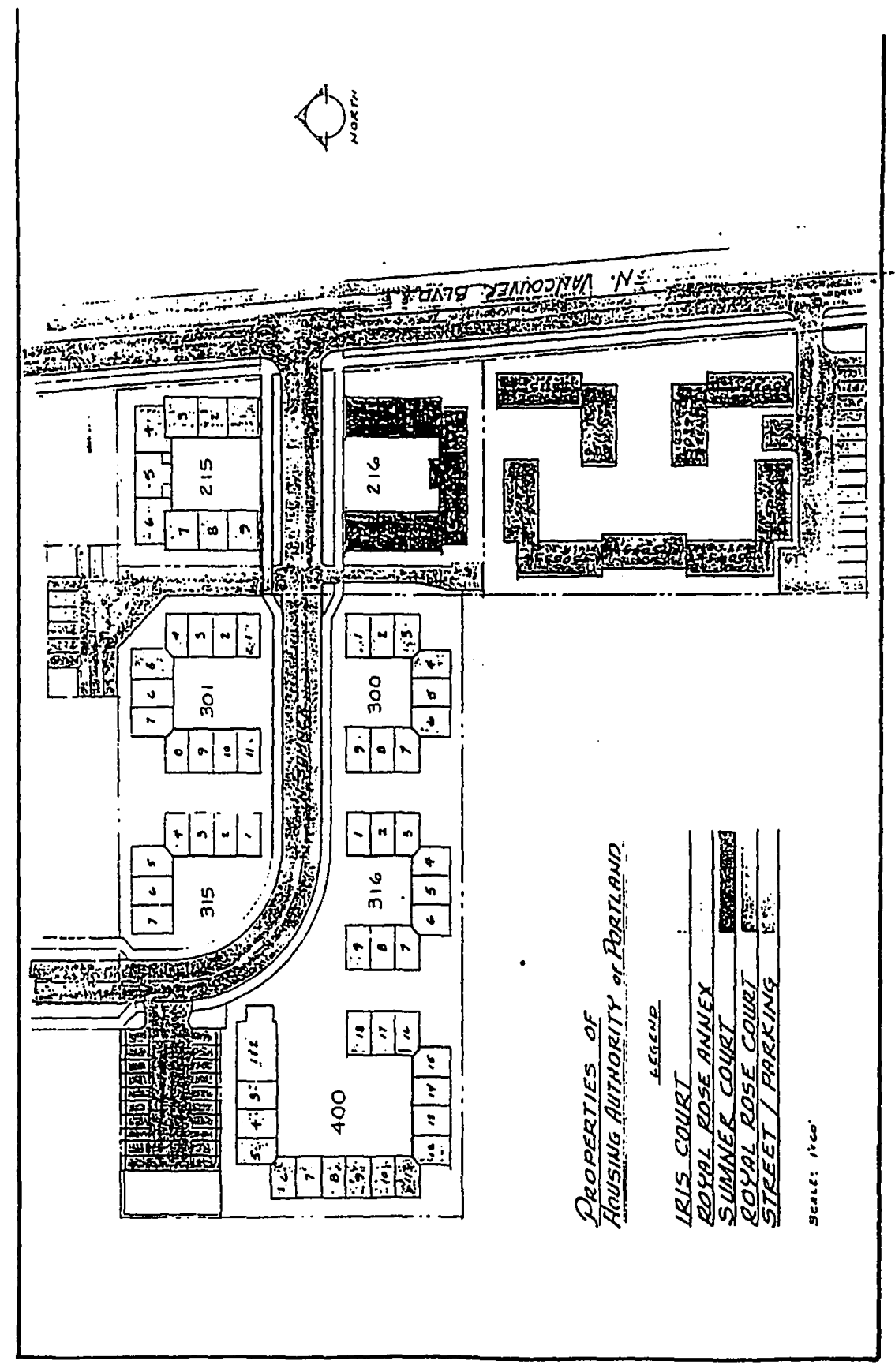


APPENDIX B

PITRE QUESTIONNAIRE 


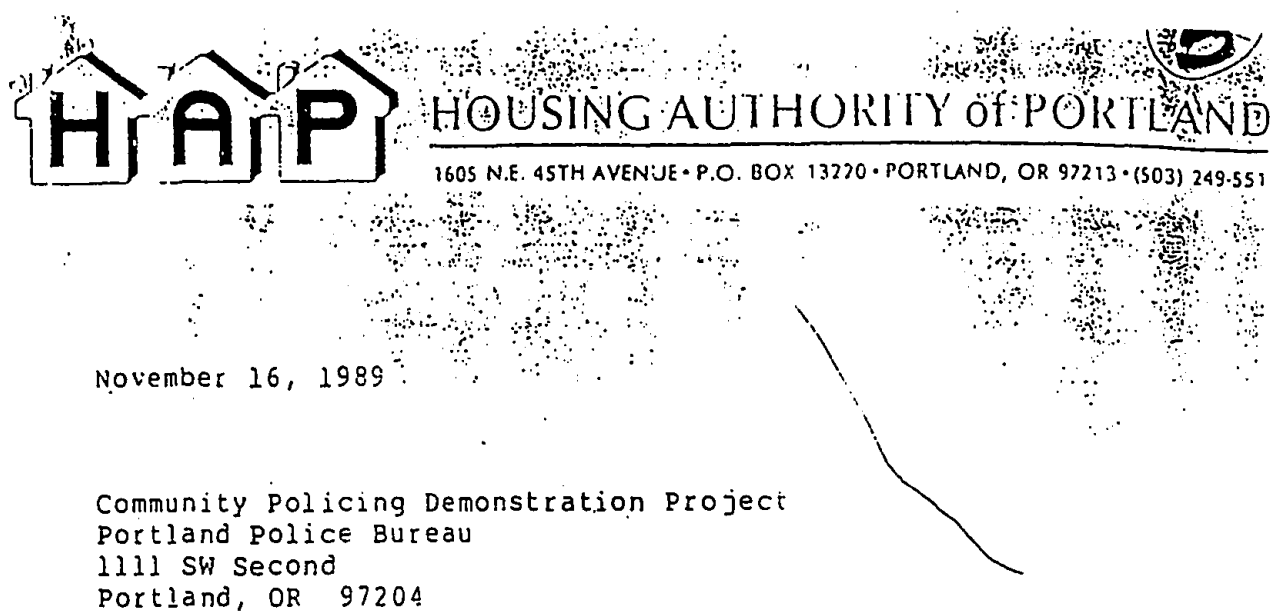

Dear Sirs:

The Housing Authority of Portland is committed to improving the guality of life for all residents in our cormunity. As the owner and manager of much of the city's lob:-ncome housing, we are especially concerned with making sure that those less fortunate in our community are provided scte, decent, and sanitary housing. As you are well aware, the increasing presence of ganos and drugs in our community has made our joo harder than ever.

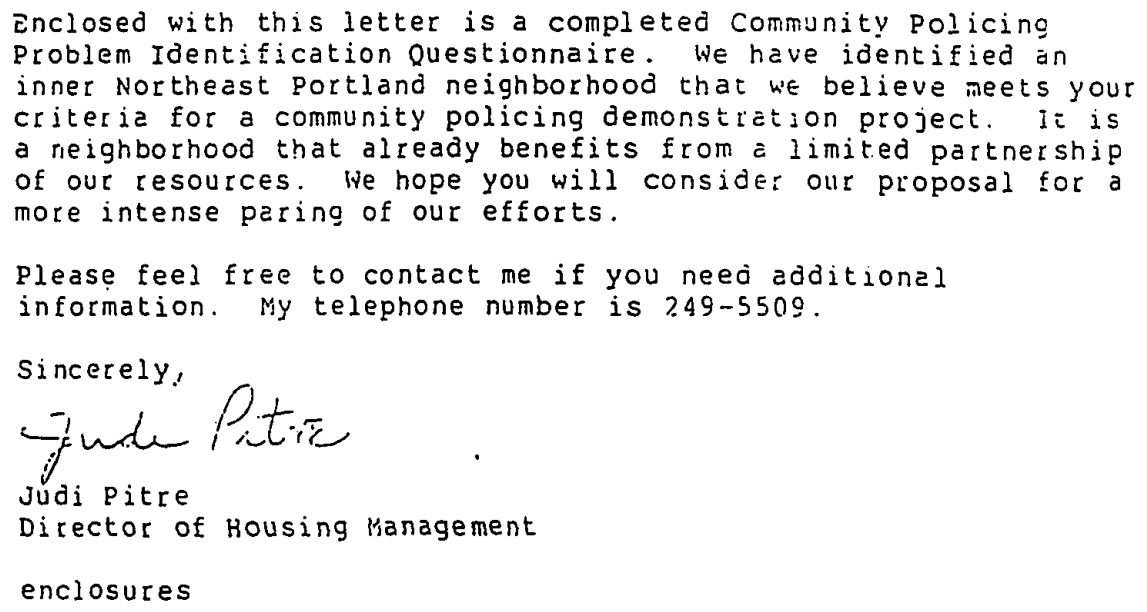



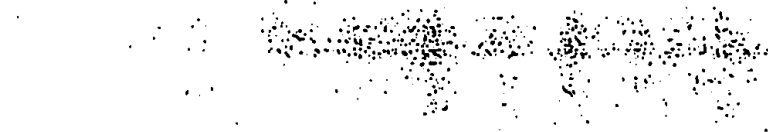

COMMONITY POLICING PROBLEM IDENTIPICATION

$$
\text { QOESTIONNAIRE }
$$

Name of individual completing questionnaire of housing Management, Housing Authoritysof portiand

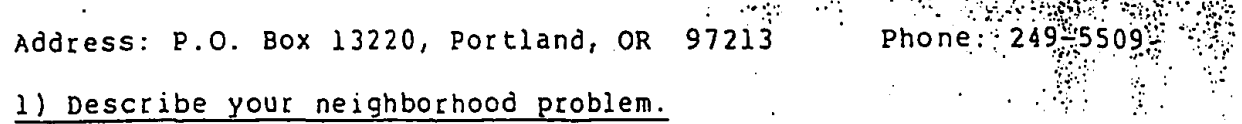

In the past several months HAP, the Portland Police Bureau, and neighbors in part of the Humboldt neighborhood have noted an increase in drug- and gang-related activity and attendant problems. While the neighborhood is composed of a variety of housing, HAP is the major landlord in this identified area owning and managing 128 units of low-income housing in the iris court, sumner court, cambridge court ai Royal Rose court and Annex developments.

HAP's residents include the chronic poor, the undereducated, at-risk youth, young single women with children, and people with special needs. A large number of residents are drug dependent - possibly as many as 508 .

Illegal activity is apparent from the amount of foot and vehicular traffic documented by Housing Authority staff, the Portland Police, $\dot{c}$ other neighbors. Drug transactions are blatantly conducted on the street and in parked cars. Unauthorized visitors are illegally occupying units - some as invited guests or relatives of resioents, some we believe through coercion and intimidation. Gang members fla colors, and incidents of violence are occurring with increasing frequency.

Law abiding residents are afraid to leave their homes to go about th day-to-day business. Others are unable or unwilling to report information ebout criminal or suspicious activity to housing authori staff or the police. Curiently, Iris Court has several vacancies tr. are proving haro to fill because of the development's reputation. ; believe other tenants would move if they had the means. Hap cannot allow more units to become vacant, because vacant units are vulneral to vandalism or occupancy by unauthorized persons.

The bottom line is that residents feel powerless to help themselves abandoned by the systems that are meant to assist and protect them. Many residents feel that they have lost control of their lives and their environment.

2) Define the geographic boundaries of this problem:

The approximate boundaries of the area are:

N. Emer son (nb25th)

Williams (east)

Alberta (south)

.. .......... (woct 

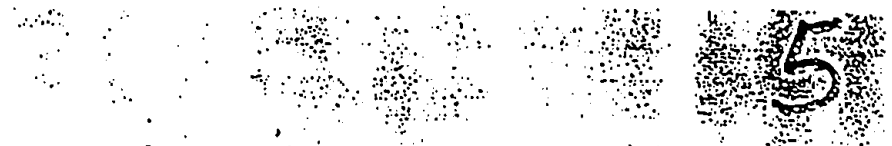

3) How many people are affected by this problem in the

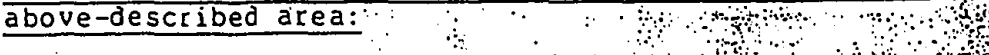
About 300 people live in BAP housing alone he cannotoffe About 300 people live in BAP housing alone he cannot offera count
on the number of residents. who live in non-HAP housing identified area.

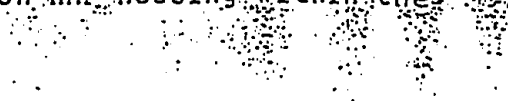

\section{4) What actions have been taken to solve this problem?}

Increased Management Presence

A new, full-time, on-site Iris court manager was hired in october. The manager's job description was modified to address the rapidly changing situation at Iris court and the neighboring developments. The manager serves as a conduit between residents and HAP, acting as HAP's eyes and ears, noting any maintenance or resident problems, distinguishing between residents and visitors, and reporting - at least daily - any suspicious, unusual or illenal activity. A second, part-time employee lives at Royal Rose, and HAP plans to ado additional staff to better cover ald 128 units. Resident meetings are helo to communicate information and find out about resident needs. hap is attempting to foster interest in a tenant organization.

Resident Lease

HAP agressively enforces its lease with regaro to illegal activity. Among the tools used are inspections, 24-hour notices for outrageous conduct or drug activity, the tresspass clause, and better screenin: of tenants.

Environmental Design

$A$ modernization project is unde:way at Iris court that includes additional lighting, recreation areas, and landscaping. HaP is considering recommendatiors on improvements in environmental desig: from the Multnomah County Sherizf's Crime Prevention Office. HAP : also working with the City of Portland on the possibility of closin off North sumner street that runs through the developments, in oroe to interrupt drug sales traffic.

Community Partnerships

RAP works closely with Portland Police Officers Hoareuf and Lieb of the North Precinct in enforcing the tresspass clause of the lease. The partnership was established earlier this year when the officers approached HAP with an offer to assist in the eviction and tresspassing of undesireable tenants and visitors. The officers have access to an Iris court unit that is used for writing reports and taking photos of tresspassed individuals. HAP considers this relationship an integral part of its plan to eradicate criminal activity from the developments and gain the trust of tenants.

Among the other community groups that HAP works with on a continui basis are the Albina Ministerial Alliance, Headstart, and the yout Gang Task Force. 


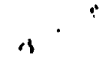
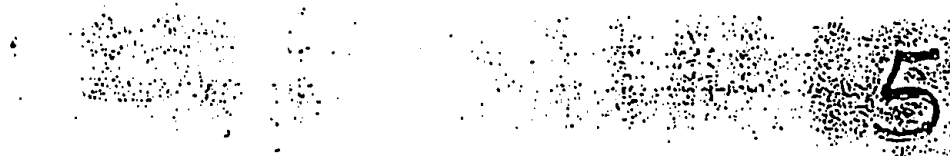

5) What are your ideas to solve this problem?

HAP proposes that the Portland police Bureau build on our existing partnership at Iris court by establishing a demonstration comunitynon policing" project.

The proposed project would empower HAP residents and their.neighbors to take control of their lives and their environment. It is: apparent that neither BAP, nor the police can solve the crime problem alone. The solution reguires a community partnership. that encompasses all parts of the community from the police, to HAP, to the business community, as well as tenants.

A "mini-precinct" at Iris court would have multiple benefits. .First of all, it would provide a continuing police presence in the developments. Secondly, it would enable officers to interact with residents to gain their trust, solicit information, and ultimately enlist them in problem-solving for treir own neighborhood. Additionally, the police could serve as part of a public safety/human service continuum, helping refer residents and their neighbors to needed and appropriate services.

\section{6) Comments:}

HAP is exploring models to better deliver social services to tenants in this area. Currently a Headstart program operates out of Iris Court and HAP would like to add other programs as well. HAP believes strongly in the community policing concept and wishes to participate in any way possible. 
APPENDIX C

BENSON MEMOS 


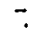

JATE : OO tober 11, 1989

ro: : /Lt. Pam Kauf f̣an

Night Relief

Through Channels

=ROM:Off. Dave Bensøn •

Night Relief

SUBJ : Mission at Sumner and Cambridge Court Apartments

From my observations since coming to Night Relief, the level of narcotics activity at the Sumner and Cambridge Court Apartments is extremely heavy between the hours of midnight to 0600 hours in the morning. cannot overstate the high level of activity that occurs on Night

Relief as compared to what I saw on Afternoons. I have personally seen known drug dealers position themselves approximately every 20 feet on the sidewalk on bo th sides of $N$. Vancouver at $N$ Sumner and on $N$. Sumner between N. Hilliams and N. Haight.

Due to this intense activity I would like to propose a two (2) day mission to belp curb some of this activity. While it is unrealistic to assume that this mission would eliminate narcotics activity at these apartment complexes, I do believe that it would bring it back to a manageable level.

The Detail would require four. (4) officers. Two (2) officers on bikes and two (:2) on foot and in a vehicle as necessary. The officers would target dealers and attempt to observe them conduct narcotics transactions then take appropriate action. These actions would include Arrests, seizures of both money and vehicles, exclusion of individuals from the Sumner Court Aparments for cause, inteliigence gathering, and identification of unknown persons involved in illegal activity.

It stands to reason that the activity in this isolated area spilis over into the ajoining neighborboods and is responsible for both serious person and property crimes. While I doubt we will be able to, as mentioned, eliminate the narcotics activity, we can prevent the problem from growing totally out of control through our efforts.

In addition, I an also aware of warrants currently being held by GET for locations in the immediate area. If we coordinate with them. I would recommend performing our mission immediately after warrant execution to maximize our impact.

Finally, this request is not an attempt to point fingers at any of the Night Relief officers working the immediate area. The call load often prohibits dedicating any self-initiated enforcement time to address the problem and ib::Is not realistic to expect district officers to be able to have any major impact when they can only spend a very limited amount of time in the area. 


$\begin{array}{lll}\text { DATE : } & \begin{array}{l}\text { October 18, } 1989 \\ \text { TO : }\end{array} \\ \begin{array}{l}\text { Captain Alan orr } \\ \text { Through Channels }\end{array} & \begin{array}{l}\text { Bureau of Police } \\ \text { Officer Dave Benson } \\ \text { Night Relief }\end{array}\end{array}$

SUBJ : Violence at Sumner/Cambridge Court Apartments

As a result of my conversation with A/Sgt. Buchtel, I am writing this memorandum in hopes of gaining the resources necessary to cope with the problems at the Sumner and Cambridge Court Apartments.

On October 11 of this year I directed a memo to A/Lt. Kauffman outlining what I saw as the problems in this area (copy attached). Using the resources available to Night Relief $\mathrm{A} / \mathrm{Lt}$. Kauffman and A/Sgt. Buchtel set out to resolve the problem. Using input from line officers special details were formed to work the area when staffing levels permitted.

I worked one such detail with officer Chamberlain Tuesday morning October 12th. Myself and off. Chamberlain effected several arrests. What was noteworthy was not the arrests in themselves, but that every single person we contacted that evening (approx. 17 individuals) were either associated or active members of gangs, mostly the Bloods.

Since I wrote the first memorandum the level of violence associated with, I believe, the narcotics activity has increased dramatically. While working the desk I haeard a call of 10 to 12 fighting behind the Cambridge Court Apartments. Tonight I took a call on a stabbing (Case \#89-96491, copy attached), and know of other acts of violence that have occurred as of late.

What I am suggesting is that the level of violence and narcotics activity it totally out of control in this area. Especially on Night Relief this area has become very dangerous for it's residents due to the level of drug trafficing and violence.

I propose dedicating additional resources to this area to help curb the problem. I have talked to the MCSo deputies (informally) who work the Columbia Villa and they indicated that they would be happy to assist with such a project. In any event, proactive action needs to be implemented to address this issue. In addition, there are other public housing profects that could also be given additional attention if we had the resources.

My comments are from an officer's perspective and do not account for management concerns or issues. Any expertise I have developed in the Sumner and Cambridge Court Apts. is a result of working with officers Lieb and Hoerauf on Afternoon Relief and certainly feel that they possess the greatest body of knowledge about this area and suggestions for corrective action.

Thanks for your consideration in this matter.

cc: Off. Chamberlain

Off. Lieb

Off. Hoerauf 
APPENDIX D

HOUSING AUTHORITY ELIGIBILITY BROCHURES 


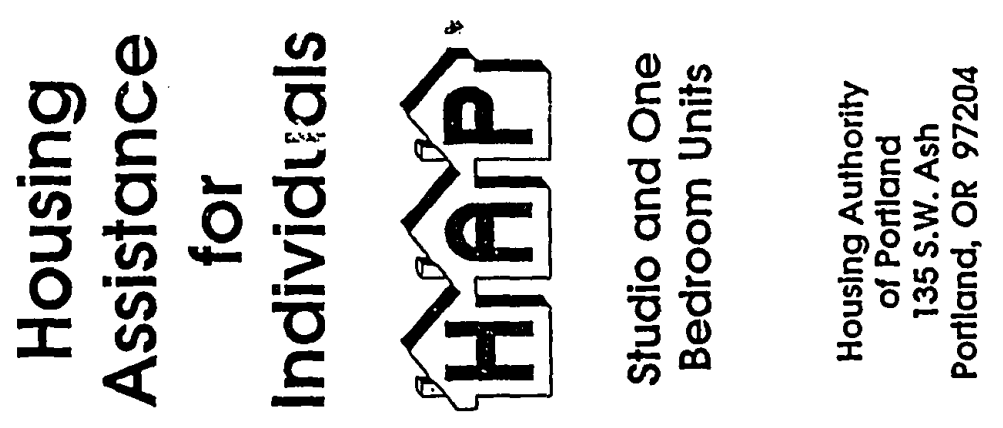

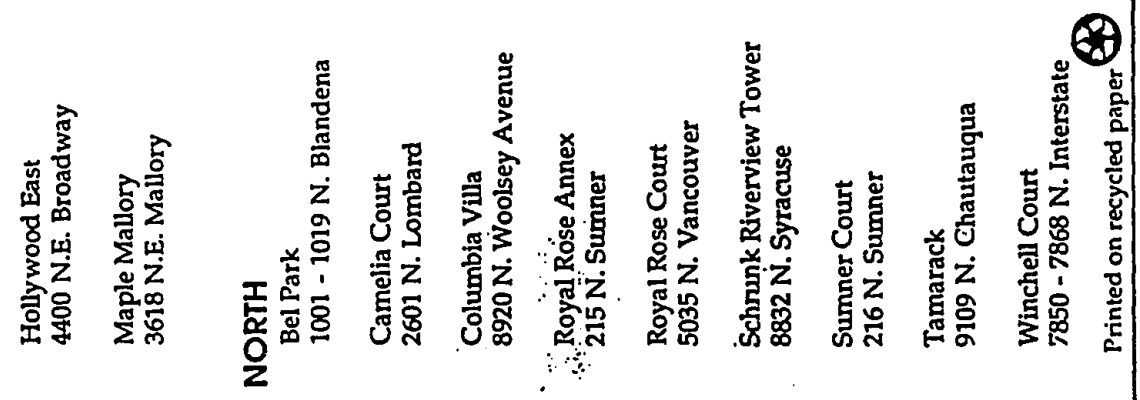

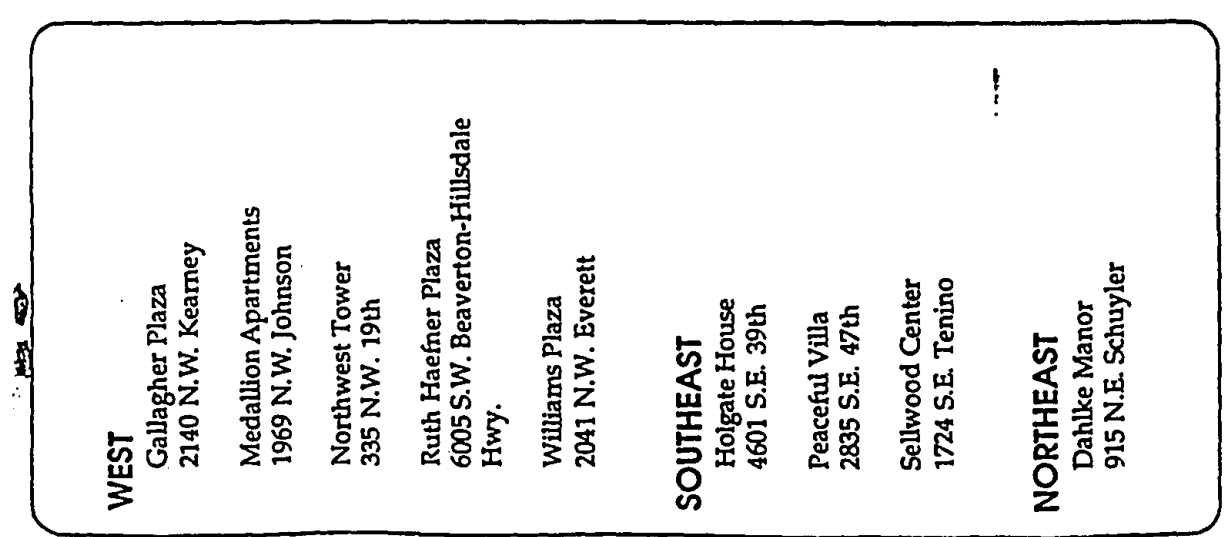



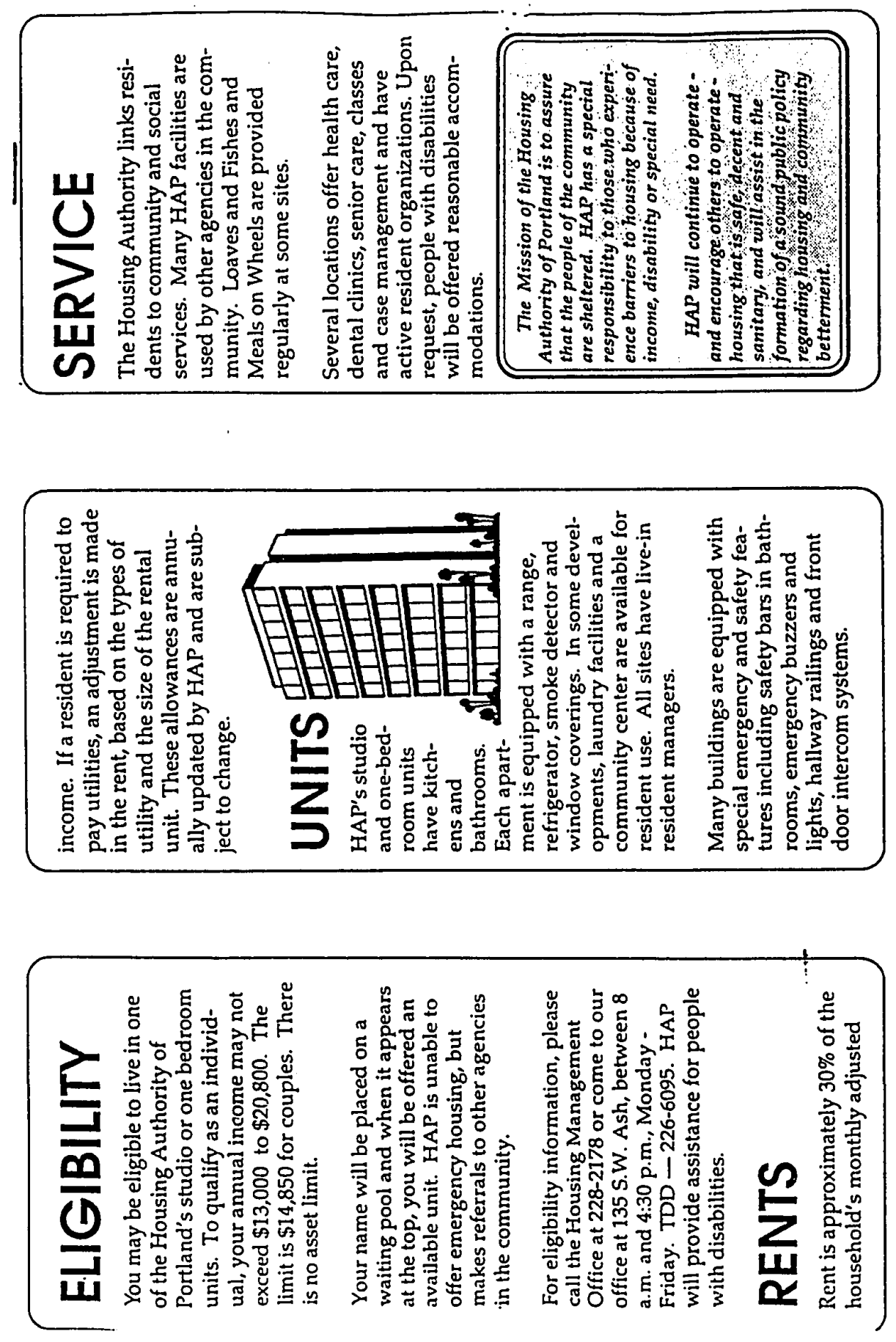


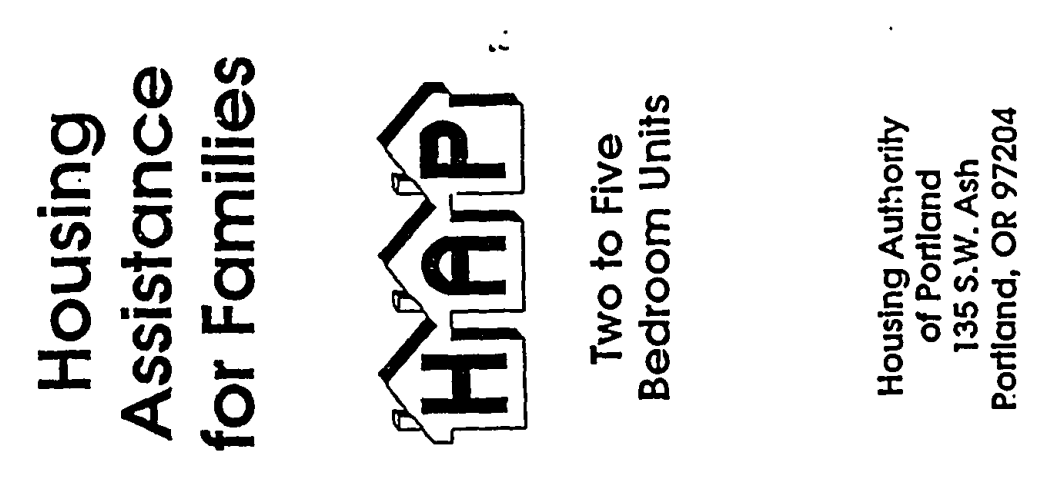

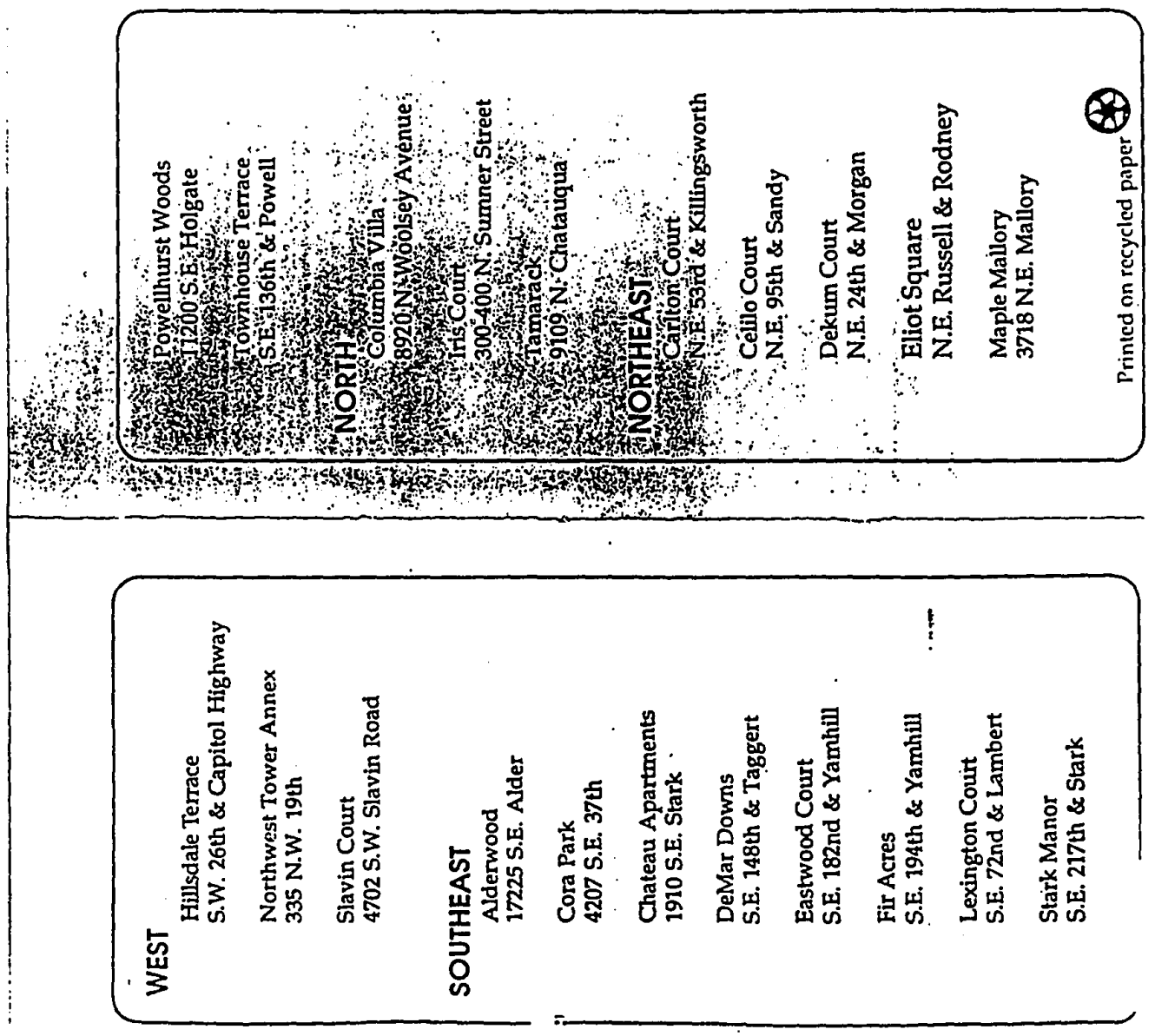



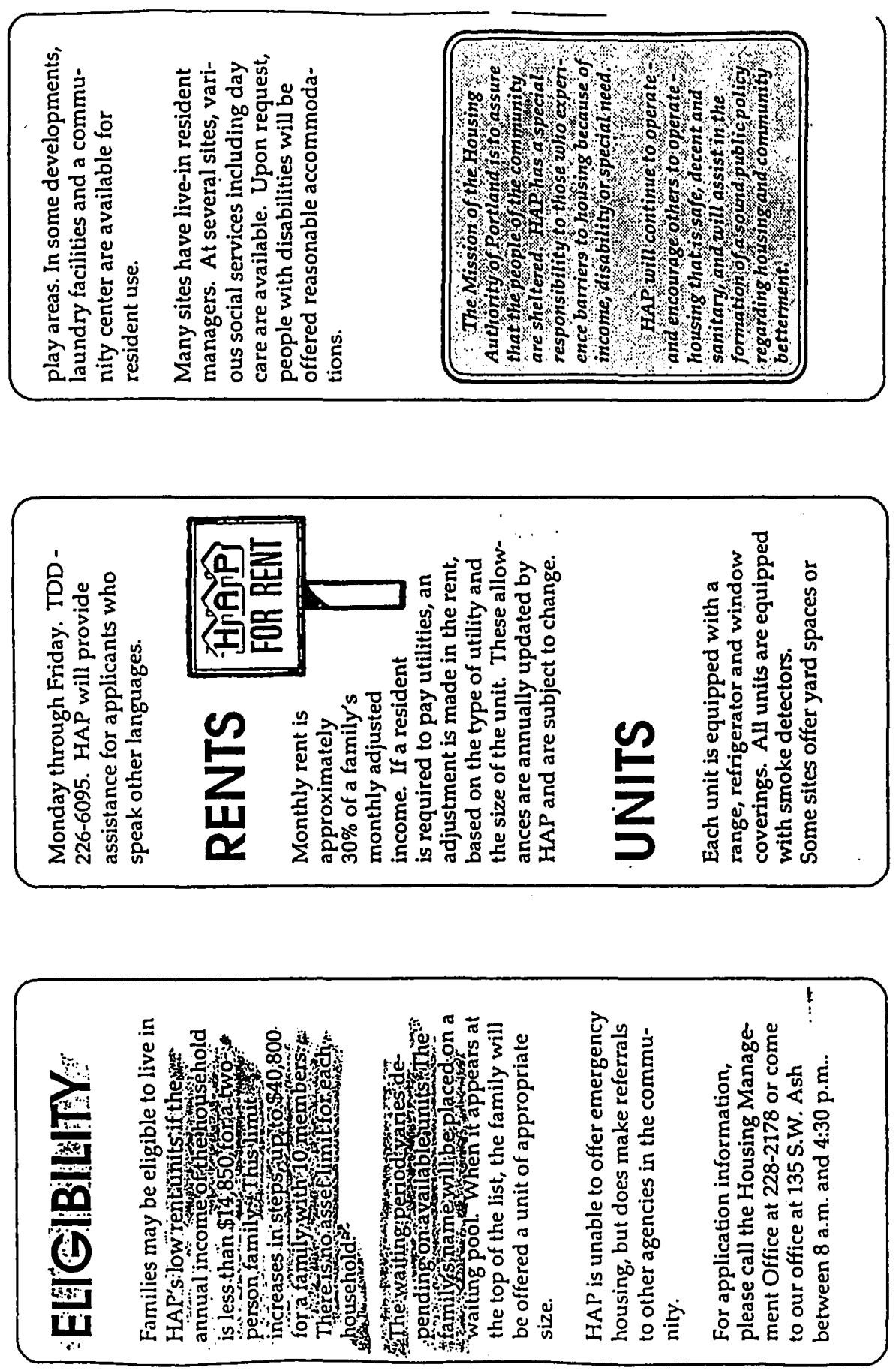
APPENDIX E

IRIS COURT TENANT SURVEY RESULTS:

1990 AND 1991 
IRIS COURT SURVEY ANSWERS $1990-1991$

1. HOW LONG HAVE YOU BEEN A RESIDENT OF THE IRIS COURT COMPLEX?

1990

0 - 6 Mos $\quad 16 \quad 218$

6 - 12 Mos $09 \quad 128$

1 - 3 Yrs. $25 \quad 328$

3 - 5 Yrs. $10 \quad 138$

5 - 7 Yrs. 01018

7 - 9 Yrs. $03 \quad 038$

9 - 12 Yrs. 06

12 - 20 Yrs. 06

20 Yrs. $+\quad 01$
088

088

018
1991

05.558

15.278

37.058

09.728

08.338

02.778

06.948

11.118

02.778

2. WHERE DID YOU LIVE BEFORE YOU LIVED BERE?

1990

PORTLAND 63

OUT OF TOWN 04

OUT OF STATE 10

828
058
138

1991

77.778

04.178

18.058

3. WHAT WOULD YOU LIKE TO SEE DONE TO IMPROVE LIFE IN THIS COMPLEX?

1990

1. Get rid of drugs and gangs

$22 \quad 218$

2. Don't know/nothing

14

138

3. Noise (loud, obscene language, slamming doors, radios, etc.)

10

4. Washroom ( $\mathrm{fix}$ and/or add more washers \& dryers

08<smiles>[Mg][Mg]</smiles>

5. Doors - fix, install night locks, keep locked.

6. Activities - Community, family, summer camp

7. Keep out non-residents

8. Screen tenants better

03

048

038 


\section{\#3. 1990 (cont)}

9. Respect/fairness (from police/ landlords)

10. Close alley north of building (Vancouver/Sumner)

11. Less traffic (foot and vehicle)

12. More freedom

0.98

13. More security

0.098

14. Police not enter without search warrant.

15. Job training

01

0.098

16. Fix heat controls

17. More supervision for children

18. Keep bicycles off walkway

01

0.098

19. Better outside lighting

0.098

20. Clean up area

$\checkmark$

0.098

21. To not have children here

0.098

22. Stop auto repair in parking lot

0.098

23. Be able to have children play outside safely

01

0.098

24. Trim shrubbery

01

0.098

25. Help with window washing/chores

01

26. To be able to move to upstairs unit.

27. Better bus service

28. Stop vandalism

29. Maintenance/better response to requests.

30. Get rid of roaches

0.098

31. Remodel complex 
$\# 3.1990$ (cont)

32. Less quarreling among tenants

33. Have no children in 1 bedroom units.

$01 \quad 0.098$

34. Cement basketball court

01

0.098

35. Work on truancy

36. Fix sewer back-up in basement

37. More hot water

\#3. 1991

1. Nothing - all is fine

2. Improve street

0.968

3. Install speed bumps

5.768

4. Decrease noise

5.768

5. Unknown

6.738

6. More child care faci,lities

2.888

7. Parking (numbered spaces)

8. Quicker response to maintenance.

$4.80 \%$

9. Keep up yard better

1.928

10. Rugs/draperies/installed/ cleaned.

1.928

11. Painted on inside.

02

12. More attendance at resident meeting.

13. Belp $2 / 3$ of residents move out. (bad ones)

01

0.968

14. Parents to watch children better.

01

.

15. Take barrier down/not stopping anything.

16. Add swimming pool 
\#3. 1991 (cont)

17. Keep drug deals down

18. More summer programs for children/families. 02

19. Safer equipment for play-ground

0.968

20. More police patrols

01

6.738

21. Get rid of dogs

22. New doors (can be kicked in)

23. Replace sawdust with grass

24. Replace sawdust with sand

25. Everyone be committed to neighborhood/take care of each other

010.968

26. More electric plug-ins

27. Metal rods to keep windows open/closed.

28. Don't give out keys to notresidents.

$01 \quad 0.968$

29. Group like-tenants in same unit

30. Parenting classes

0.968

31. Support group for kids.

32. Less violence

33. Install carpets

34. Cut and thin hedges

35. Screen tenants

36. Need laundry in each unit (much better now though)

37. Screen doors

38. Get rid of manager

39. Lower rent

01

0.968

40. More grass 
4. SINCE LAST SUMMER, HAS THIS COMPLEX BECOME BETTER, GOTTEN WORSE OR STAYED ABOUT THE SAME?

\begin{tabular}{lllll} 
& 1990 & & \multicolumn{2}{c}{1991} \\
BETTER & 41 & 538 & 47 & 65.278 \\
WORSE & 14 & 188 & 08 & 11.118 \\
SAME & 22 & 298 & 13 & 18.058 \\
UNKNOWN & - & - & 04 & 05.558
\end{tabular}

5. WRERE WOULD YOU SEND A FRIEND THAT MEEDS DRUG OR RICOBOL COUNSELIING? 1990 . 388

Rehabilitation Center

St. Vincent DePaul

078

NA/AA

068

Alcohol Abuse Center

048

Blue/yellow pages

048

Schick Center

038

C.O.D.A.

028

TASK

028

Treatment Center

028

Jail

028

Justice Center

018

Youth Resource

018

NARA

018

White Buffalo

3rd \& Oak Rehab

018

County Health

018

Kaiser

018

Salvation Army

018

Delaunay

018

P.C.R.

018

Look out for self

018

Police Dept.

018

Church

018

Hot line

018

018 
15. WRERE WOULD YOU SEND A FRIEND THAT NEEDS DRUG OR ALCOHOL COUNSELLING?

$\underline{1991}$

\begin{tabular}{|c|c|c|}
\hline Don't know & 32 & 38.558 \\
\hline$A A$ & 02 & 02.408 \\
\hline Look in phone book & 03 & 03.618 \\
\hline Urban League & 02 & 02.408 \\
\hline Veterans & 03 & 03.618 \\
\hline Sylvester & 02 & 02.408 \\
\hline Community Health Nurse & 01 & 01.208 \\
\hline Rehab/Treatment Center & 05 & 06.028 \\
\hline Church & 02 & 02.408 \\
\hline Doctor & 01 & 01.208 \\
\hline Welfare & 01 & 01.208 \\
\hline "Stay Clean Clinic" & 01 & 01.208 \\
\hline $\begin{array}{l}\text { "Jesus Against Drugs/ } \\
\text { Alcohol" }\end{array}$ & 01 & 01.208 \\
\hline $\begin{array}{l}\text { Would not recommend any/ } \\
\text { don't work }\end{array}$ & 01 & 01.208 \\
\hline Kaiser & $\$ 1$ & 01.208 \\
\hline United Way & 01 & 01.208 \\
\hline Crisis line & 01 & 01.208 \\
\hline Drug center on williams & 01 & 01.208 \\
\hline Police & 02 & 02.408 \\
\hline Relatives & 01 & 01.208 \\
\hline TASK & 03 & 3.618 \\
\hline Union \& Burnside & 01 & 01.208 \\
\hline Mental Bealth & 02 & 02.408 \\
\hline Look in Resource Guide & 01 & 01.208 \\
\hline Project for Comm. Recvy. & 02 & 02.408 \\
\hline Powell House & 01 & 01.208 \\
\hline Hooper & 02 & 02.408 \\
\hline To a sponsor & 01 & 01.208 \\
\hline Library & 01 & 01.208 \\
\hline Damasch & 01 & 01.208 \\
\hline Detox & 01 & 01.208 \\
\hline To a counsellor & 01 & 01.208 \\
\hline
\end{tabular}


\#5. 1991

(cont)

NARA

01

01.208

6. DO YOU NEED HELP FINDING A JOB THAT YOU LIKE DOING?

\begin{tabular}{lllll} 
& 1990 & & \multicolumn{2}{c}{1991} \\
YES & 15 & 19.008 & 15 & 21.128 \\
NO & 62 & 81.008 & 45 & 63.388
\end{tabular}

7. IF NO, WHY NOT? $\underline{1990}$

Already employed

$18 \quad 298$

Unable to work

$19 \quad 318$

other (explain)

25

408

Other (explained)

Retired $11 \quad 44 \%$

will be in school $02 \quad 08 \%$

Likes to paint $01 \quad 048$

Homemaker $\quad 301 \quad 048$

Social Security $01 \quad 048$

Welfare $01 \quad 048$

Doing babysitting $01 \quad 048$

Can find on own $01 \quad 048$

Job Corp $01 \quad 048$

Just had baby $01 \quad 048$

No comment 01

Needs to stay home 01

Family involved in

counselling 01

048

048

Can go to old job $01 \quad 048$ 
7. IF NO, WHY NOT"

$\underline{1991}$

$\begin{array}{lll}\text { Already employed } & 11 & 15.278 \\ \text { Unable to work } & 05 & 06.948 \\ \text { No Answer } & 25 & 34.728 \\ \text { Other (explain) } & 31 & 43.058\end{array}$

EXPLAIN:

$\begin{array}{lll}\text { Retired } & 19 & 57.578\end{array}$

I do sewing $01 \quad 03.038$

Foster Grandparent $01 \quad 03.038$

Alternative School $01 \quad 03.038$

Going to school $06 \quad 18.18$ \%

Three kids/care for $02 \quad 06.258$

Getting married $01 \quad 03.038$

Does not relate well $01 \quad 03.038$

Lost lots of jobs $01 \quad 03.038$

B. WHO BAS RELPED YOU IN THE, PAST? $\underline{1990}$

$\begin{array}{lll}\text { Self } & 30 & 358 \\ \text { None } & 17 & 208 \\ \text { Friend/Family } & 12 & 148 \\ \text { Welfare } & 04 & 058 \\ \text { Not Apply } & 03 & 038 \\ \text { Unemployment office } & 02 & 028 \\ \text { Counselor } & 02 & 028 \\ \text { Church } & 02 & 028 \\ \text { Mental Health } & 01 & 018 \\ \text { School (PCC) } & 01 & 018 \\ \text { Private Industries C. } & 01 & 018 \\ \text { Piledrivers Union } & 01 & 018 \\ \text { Veterans } & 01 & 018 \\ \text { Neighbor } & 01 & 018 \\ \text { Temporary Employment } & 01 & 018 \\ \text { Albina Buman Resc. } & 01 & 018\end{array}$


8. 1990

(cont)

$\begin{array}{lll}\text { Nursing Agency } & 01 & 018 \\ \text { PIC } & 01 & 018 \\ \text { Manpower } & 01 & 018 \\ \text { Albina Employment } & 01 & 018 \\ \text { PDX Private Counselling } & & \\ \text { Industry } & 01 & 018 \\ \text { King Center } & 01 & 018\end{array}$

8. WHO HAS HELPED YOU IN THE PAST? $\underline{1991}$

$\begin{array}{lll}\text { Mother } & 02 & 02.778 \\ \text { No answer } & 24 & 33.338 \\ \text { Insights Team } & 01 & 01.388 \\ \text { St. Vincent DePaul } & 02 & 02.778 \\ \text { Housing Authority } & 02 & 02.778 \\ \text { Self } & 18 & 25.008 \\ \text { Police officer/Complex } & 01 & 01.388 \\ \text { None } & 06 & 08.338 \\ \text { Friends } & 02 & 02.778 \\ \text { Jefferson High } & 01 & 01.388 \\ \text { State Employment } & 05 & 06.948 \\ \text { Union } & 01 & 01.388 \\ \text { Welfare } & 03 & 04.168 \\ \text { U.S. Navy } & 01 & 01.388 \\ \text { Sharmini/Iris Ct. } & 01 & 01.388 \\ \text { TASK } & 01 & 01.388 \\ \text { Kelly Services } & 01 & 01.388\end{array}$


9. WHAT DO YOU THINK OF JOB OPPORTUNITIES IN THIS AREA? TREY ARE:

1990

VERY GOOD

GOOD

FAIR

POOR

VERY POOR

NO ANSWER

07

13

17

21

10

09

3
7
21
10
09

09.008
17.008
22.00
27.008
13.008
12.008

03
07
22
13
09
18

1991

10. DO YOU NEED HELP FINDING GOOD HEALTH CARE?

\begin{tabular}{lllll} 
& 1990 & & \multicolumn{2}{c}{1991} \\
YES & 09 & 12.008 & 14 & 19.448 \\
NO & 68 & 88.008 & 35 & 48.618 \\
NO ANS & -- & -- & 23 & 31.948
\end{tabular}

11. WEERE DO YOU CURRENTLY GET HELP? $\underline{1990}$

MEDICARE/MEDICAID

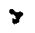

$U$ OF O MED SCEOOL

KAISER

EMANUAI EMERGENCY

N/A - UNK - NO ANSWER

N.E. HEALTH CENTER

PRIVATE INSURANCE

SECURE HORIZONS

VETERANS

ADULT FAMILY SERVICES

A.S.F . COVERAGE

CARSON CENTER (MLK/KILL)

WEST SIDE CLINIC

URBAN INDIAN CLINIC

NORTH PORTLAND BEALTE CLINIC

04.168

09.728

30.558

18.058

$12.50 \%$

25.008 
11. 1990

(CONT)

$\begin{array}{lll}\text { PORTLAND ADVENTIST } & 01 & 01.008 \\ \text { METROPOLITAN CLINIC } & 01 & 01.008 \\ \text { WELFARE } & 01 & 01.008\end{array}$

11. WHERE DO YOU CURRENTLY GET BELP? $\underline{1991}$

$\begin{array}{lll}\text { PROVIDENCE GOOD HEALTH PLAN } & 02 & 02.638 \\ \text { NORTHEAST COMMUNITY BEALTH } & 10 & 13.158 \\ \text { RAISER } & 10 & 13.158 \\ \text { NONE } & 13 & 17.108 \\ \text { OHSU } & 09 & 11.848 \\ \text { ALAMEDA HEALTH CLINIC } & 01 & 01.318 \\ \text { MEDICARE/MEDICAID } & 04 & 05.268 \\ \text { CLINIC UP STREET } & 01 & 01.318 \\ \text { PRIVATE DOCTOR } & 05 & 06.578 \\ \text { ADULT FAMILY SERVICES } & 01 & 01.318 \\ \text { EMANUEL } & 06 & 07.898 \\ \text { N. PORTLAND BEAITH } & 01 & 01.318 \\ \text { WELFARE } & 06 & 07.898 \\ \text { VETERANS } & 02 & 02.638 \\ \text { GOOD SAM } & 01 & 01.318 \\ \text { INSURANCE (SECURE HORIZONS) } & 02 & 02.638 \\ \text { MEDIC-AIDE } & 01 & 01.318 \\ \text { SCHOOL } & 01 & 01.318\end{array}$

12. WHAT DO YOU THINR OF BEALTH SERVICE IN THIS AREA? (SERVICES ARE:)

1990

1991

$\begin{array}{lllll}\text { VERY GOOD } & 19 & 25.008 & 14 & 19.448 \\ \text { GOOD } & 26 & 34.008 & 19 & 26.388 \\ \text { FAIR } & 23 & 30.008 & 18 & 25.008 \\ \text { POOR } & 03 & 04.008 & 07 & 09.728 \\ \text { VERY POOR } & 01 & 01.008 & 00 & 00.008 \\ \text { NO ANSWER } & 05 & 06.008 & 14 & 19.448\end{array}$


13. DO YOU NEED HELP WITH CHILDCARE (BABYSITTING)

\begin{tabular}{llllll}
\multicolumn{1}{r}{1990} & & & \multicolumn{2}{c}{1991} \\
YES & 12 & 16.008 & 13 & 20.838 \\
NO & 65 & 84.008 & 52 & 72.228 \\
NO ANSWER & -- & -- & 05 & 06.948
\end{tabular}

14. WHAT KIND OF HELP DO YOU GET NOW? $\underline{1990}$

$\begin{array}{lll}\text { NONE } & 50 & 65.008 \\ \text { RELATIVE/FAMILY } & 13 & 17.008 \\ \text { BABY SITTER } & 06 & 08.008 \\ \text { GIRL/BOY FRIEND } & 02 & 03.008 \\ \text { DAYCARE } & 02 & 03.008 \\ \text { CHILD IN SCHOOL } & 01 & 01.008 \\ \text { P.I.V.O.T. } & 01 & 01.008 \\ \text { TRI-COUNTY RESPITE CARE } & 01 & 01.008\end{array}$

14. WHAT KIND OF BELP DO YOU GET NOW? $\underline{1991}$

NO ANSWER

47.888

RELATIVE

15.498

NONE

18.308

PAY FOR OWN

07.048

FRIENDS

04.228

COMMUNITY SUPPORT 01

01.408

MANAGER

01,408

GOES TO SCHOOL W/ME 01

$0 1 \longdiv { 4 0 8 }$

HEAD START 01

01.408

WELFARE PAID/CERTIFIED 01

01.408

SCHOOL

01

01.408 
15. WHAT DO YOU THINK OF THE PHYSICAL CONDITION OF THIS COMPLEX? (WOULD YOU SAY THAT IT IS:)

1990

1991

$\begin{array}{lllll}\text { VERY GOOD } & 16 & 21.008 & 15 & 20.838 \\ \text { GOOD } & 29 & 36.008 & 21 & 29.168 \\ \text { FAIR } & 27 & 35.008 & 30 & 41.668 \\ \text { POOR } & 03 & 04.008 & 03 & 04.168 \\ \text { VERY POOR } & 02 & 03.008 & 03 & 04.168\end{array}$

16. WHAT TYPE OF JOB HAVE THE ON-SITE MANAGERS DONE? (WOULD YOU SAY THAT IT IS:)

$\begin{array}{lllll}\text { VERY GOOD } & 22 & 29.008 & 18 & 24.658 \\ \text { GOOD } & 28 & 36.008 & 12 & 16.438 \\ \text { FAIR } & 11 & 14.008 & 20 & 27.398 \\ \text { POOR } & 11 & 14.008 & 09 & 12.328 \\ \text { VERY POOR } & 05 & 06.008 & 10 & 13.698 \\ \text { NO ANSWER } & -- & -- & 04 & 05.478\end{array}$

16A. EXPLAIN

$$
1990
$$

Usually gets things done fast

23.008

Excellent job

15.008

Many improvements made

09.008

Good friendly people

06.008

Not getting job done

06.008

clean except for laundry

$06.00 z$

Landlord works with tenant

$0 \$ .00 \%$

Not always available

06.008

Don't clean laundry

04.008

Listens to tenants

04.008

slow response

less loitering/drug dealing

04.008

Had to buy own paint

02.008

Don't replace lightbulbs

02.008

Bad actitude

02.008

Repair work not done correct

01.008

01.008 
16A. (Cont)

$\underline{1990}$

Heater not fixed (uses oven)

16A. EXPLAIN

1991

slow to respond

16.988

Great job

13.208

Helpful

05.668

I don't need much

05.668

Last two years poor

01.888

Needs paint inside

01.888

Manager needs help

03.778

Does not keep grounds up

03.778

All the managers that want a job are

good/those that don't are not good.

01.888

Always get answering service

$01.88 \%$

Can't get help unless kitchen on fire.

01.888

Rude

03.778

Papers get stacked up

01.888

No heat last two years

01.888

Always closed or won't answer door/

(If not dying or haven't been shot-forget it)

05.668

Took three months to get toilet fixed

$01.88 \%$

Laundry should be open longer hours

on weekend.

01.888

Does very good with what he has.

Leaky faucets (Won't come to fix)

$01.88 \%$

In one ear and out the other

01.888

Nothing done

01.888

$\$ 6.00$ charge for letting in locked out tenant

Sony is good --- Maintenance slow

Bandrail needs repair

Can't get door fixed

Mr. Peterson is a gem

03.778

02

01.888

01

01.888

01

01.888

01

$01.88 \%$

Doesn't do anything/she's a tweek 
16. EXPLAIN

$\underline{1991 \text { (CONT) }}$

Had to go beyond on-site manager

$01 \quad 01.888$

17. HOW AFRAID ARE YOU WHEN YOU GO ANYWHERE IN THE AREA AFTER DARK? (WOURD YOU SAY THAT YOU ARE:)

1990

1991

$\begin{array}{lllll}\text { NOT AFRAID } & 24 & 31.008 & 26 & 36.118 \\ \text { SOMEWHAT AFRAID } & 21 & 27.008 & 21 & 29.168 \\ \text { VERY AFRAID } & 32 & 42.008 & 21 & 29.168\end{array}$

18. HOW AFRAID ARE YOU ABOUT BEING BEATEN UP BY A STRANGER? (WOULD YOU SAY THAT YOU ARE:)

1990

1991

$\begin{array}{lllll}\text { NOT AFRAID } & 34 & 44.008 & 31 & 43.058 \\ \text { SOMEWHAT AFRAID } & 18 & 23.008 & 13 & 18.05 \% \\ \text { VERY AFRAID } & 25 & 32.008 & 27 & 37.508 \\ \text { NO ANSWER } & -- & -- & 01 & 01.888\end{array}$

19. HOW AFRAID ARE YOU ABOUT RAVING SOMEONE BREAK INTO YOUR HONE WHILE YOU ARE NOT AT HOME? (WOULD YOU SAY THAT YOU ARE:)

1990

1991

$\begin{array}{lllll}\text { NOT AFRAID } & 27 & 35.008 & 30 & 41.098 \\ \text { SOMEWHAT AFRAID } & 18 & 23.008 & 20 & 27.398 \\ \text { VERY AFRAID } & 32 & 42.008 & 23 & 31.508\end{array}$

20 HOW AFRAID ARE YOU ABOUT DRUG DEALING IN THE AREA? (WOULD YOU SAY THAT YOU ARE:)

1990

NOT AFRAID 23

SOMEWHAT AFRAID 20

VERY AFRAID
34
30.008

26.008

44.008

1991

34

46.578

23.488

30.138 
21. HOW AFRAID ARE YOU ABOUT GANG ACTIUITX IN THE AREA? (WOULD YOU SAY THAT YOU ARE:)

1990

NOT AFRAID

SOMEWHAT AFRAID

VERY AFRAID

NO ANSWER
27

20

30

$-$

35.008
26.008
39.008
-

35.008

39.008

$-$

1991

36.238

27.538

34.788

01.448

22. HOW IS POLICE SERVICE IN THE AREA?

(WOULD YOU SAY THAT IT IS:)

1990

1991

VERY GOOD

27

35.008

36.008

18.008

08.008

03.008

$-$

25

19

24

01

GOOD

FAIR

02

NO ANSWER

$--$

23. HOW ARE THE POLICE DOING IN WORKING WITH RESIDENTS TO SOLVE PROBLEMS? (WOULD YOU SAY TBEY ARE DOING:)

1990

1991

$\begin{array}{lllll}\text { VERY GOOD } & 22 & 29.008 & 22 & 30.558 \\ \text { GOOD } & 22 & 29.008 & 21 & 29.168 \\ \text { FAIR } & 20 & 26.008 & 09 & 12.508 \\ \text { POOR } & 09 & 12.008 & 07 & 09.728 \\ \text { VERY POOR } & 04 & 05.008 & 02 & 02.778 \\ \text { NO ANSWER } & -- & -- & 11 & 15.278\end{array}$


24. HOW ARE THE POLICE DOING IN TREATING PEOPLE FAIRLY? (WOULD YOU SAY THEY ARE DOING:)

1990

1991

$\begin{array}{lllll}\text { VERY GOOD } & 18 & 23.008 & 14 & 19.448 \\ \text { GOOD } & 20 & 26.008 & 20 & 27.778 \\ \text { FAIR } & 23 & 30.008 & 16 & 22.228 \\ \text { POOR } & 11 & 14.008 & 05 & 06.948 \\ \text { VERY POOR } & 05 & 07.008 & 02 & 02.778 \\ \text { NO ANSWER } & -- & -- & 15 & 20.838\end{array}$

25. HOW ARE THE POLICE DOING IN BEING POLITE TO PEOPLE? (WOULD YOU SAY TEEY ARE DOING:)

1990

1991

\begin{tabular}{|c|c|c|c|c|}
\hline VERY GOOD & 22 & 29.008 & 28 & 38.888 \\
\hline GOOD & 20 & 26.008 & 19 & 26.388 \\
\hline FAIR & 23 & 30.008 & 10 & 13.888 \\
\hline POOR & 05 & 07.008 & 04 & 05.558 \\
\hline VERY POOR & 07 & 09.008 & 01 & 01.388 \\
\hline NO ANSWER & - & -- & 10 & 13.888 \\
\hline
\end{tabular}

26. HAVE YOU BEEN A VICTIM OF A CRIME SINCE IAST SUMMER?

\begin{tabular}{lrlll}
\multicolumn{1}{c}{1990} & & \multicolumn{2}{c}{1991} \\
YES & 17 & 22.008 & 10 & 13.698 \\
NO & 60 & 78.008 & 62 & 84.938 \\
NO ANSWER & -- & -- & 01 & 01.368 \\
& & & \\
26A. IF YES PLEASE EXPLAIN & & & \\
\hline I990 & & 26.008 \\
Burglary & 05 & 16.008 \\
Assaulted & 03 & 11.008 \\
Theft Irom auto & 02 & 05.008 \\
Shooting at house & 01 & 05.008 \\
Petty theft by visitors & 01 & 05.008 \\
Attempted robbery by kids & 01 & 05.008 \\
Slash tires/took hub caps & 01 &
\end{tabular}


26a EXPLAIN (CONT)

1990

$\begin{array}{lll}\text { Someone came into house } & 01 & 05.008 \\ \text { Son victim (unknown) } & 01 & 05.008 \\ \text { Involved in riot in complex } & 01 & 05.008 \\ \text { Police Brutality } & 01 & 05.008 \\ \text { Purse snatch } & 01 & 05.008\end{array}$

26 IF YES EXPLAIN

1991

Robbed

$01 \quad 06.668$

Fight with boyfriend

$01 \quad 06.668$

Assaulted \& robbed

House burglarized

$01 \quad 06.668$

Beaten up

06.668

Theft from vehicle

$01 \quad 06.668$

$01 \quad 06.668$

27. DID YOU CAIT THE POLICE?

$\begin{array}{ccccc} & 1990 & ? & & 1991 \\ \text { YES } & 13 & 68.008 & 06 & 40.008 \\ \text { NO } & 06 & 32.008 & 09 & 60.008\end{array}$

28. IF NO, WHY NOT?

1990

Didn't want to cause trouble

17.008

They didn't get anything

17.008

No hope of recovery

17.008

Don't get cooperation from police

17.008

Everytime he calls the police, he goes to jail

17.008

Unknown

17.008 
28. IF NO, WHY NOT?

$\underline{1991}$

$\begin{array}{lll}\text { Didn't think it was necessary } & 01 & 33.338 \\ \text { Didn't think it would do any good } & 01 & 33.338 \\ \text { Does no good; I called police about } & \\ \text { a shooting and the police harassed me. } & 01 & 33.338\end{array}$

29. WHAT CATEGORY DESCRIBES YOU?

19901991

$\begin{array}{lllll}\text { SINGLE WOMAN } & 25 & 32.008 & 24 & 33.808 \\ \text { SINGLE MAN } & 06 & 08.008 & 09 & 12.678 \\ \text { COUPLE W/CHILDREN } & 06 & 08.008 & 05 & 07.048 \\ \text { COUPLE W/O CEILDREN } 07 & 09.008 & 06 & 08.458 \\ \begin{array}{l}\text { SINGLE WOMAN, HEAD } \\ \text { OF HOUSE W/CEILDREN }\end{array} & 32 & 42.008 & 27 & 38.028 \\ \begin{array}{l}\text { SINGLE MAN, HEAD OF } \\ \text { HOUSE W/CGILDREN }\end{array} & 01 & 01.00 & 00 & 00.008\end{array}$

30. WHAT AGE GROUP DO YOU FIT. INTO?

$1990 \quad 1991$

$\begin{array}{lllll}18-21 & 14 & 17.508 & 12 & 16.668 \\ 22-30 & 18 & 22.508 & 17 & 23.618 \\ 31-40 & 06 & 07.508 & 07 & 09.728 \\ 41-50 & 09 & 11.25 & 06 & 08.338 \\ 51-60 & 08 & 10.008 & 06 & 08.338 \\ 60+ & 25 & 31.258 & 24 & 33.338\end{array}$

31. AS OF LAST SUMMER, HOW MUCH FORMAL SCHOOLING BAVE YOU HAD? (WOULD IT BE:)

1990

Never went to school

8 th grade or less

9 th - 12th grade

Highschool graduate

$\begin{array}{ll}01 & 01.008 \\ 13 & 14.008 \\ 14 & 16.008 \\ 33 & 37.008\end{array}$

1991

04.448

16.668

11.118

31.118 
31. (CONP)

Vocational training

16

18.008

14

15.558

Some college

13

14.008

17

18.888

31A. NUMBER OF YEARS OF COLLEGE

1990

1991

$\begin{array}{lll}9 \text { MOS } & 1 \\ 1 \text { YR } & 3 \\ 11 / 2 \text { YR } & 2 \\ 2 \text { YR } & 6 \\ 3 \text { YR } & 1\end{array}$

6 MOS 1

1 YR 5

2 YR 5

3 YR 1

32. WHAT IS THE RESIDENTS RACE CATEGORY?

\begin{tabular}{lllll}
\multicolumn{2}{c}{1990} & & & 1991 \\
BLACK & 50 & 62.008 & 44 & 62.858 \\
HISPANIC & 02 & 02.008 & 00 & 00.008 \\
WHITE & 22 & 27.008 & 16 & 22.858 \\
ASIAN & 00 & 70.008 & 00 & 00.008 \\
NATIVE AMER. & 04 & 05.00 & 04 & 05.718 \\
OTHER & 03 & 04.008 & 00 & 00.008 \\
NO ANSWER & -- & -- & 06 & 08.578
\end{tabular}

33. WHAT IS THE SEX OF RESIDENT?

$\begin{array}{lllll} & & & & 1991 \\ \text { MALE } & 1990 & 22.008 & 14 & 19.448 \\ \text { FEMALE } & 63 & 78.008 & 52 & 72.228 \\ \text { NO ANSWER } & -- & -- & 06 & 08.338\end{array}$


THE FOLLOWING QUESTIONS WERE ASKED IN THE 1991 SURUEY ONLY

34. HAVE YOU MET DAVE GRADY AND SCOTT JOHNSON ON THE NEIGHBORHOOD RESPONSE TEAM?

$\begin{array}{lll}\text { YES } & 28 & 38.888 \\ \text { NO } & 44 & 61.118\end{array}$

35. WHICE OF THE ACTIVITIES AND SERVICES AT IRIS COURT HAVE YOU OR YOUR FAMILY PARTICIPATED IN?

$\begin{array}{lll}\text { ACTIVITIES FOR CHILDREN } & 18 & 11.848 \\ \text { JOB-HEAITH FAIR } & 10 & 06.578 \\ \text { SOCIAL GATHERINGS } & 35 & 23.028 \\ \text { EMPLOYMENT OFFICE } & 12 & 07.898 \\ \text { "SNACK ATTACK" NUTRITION CLASS } & 23 & 15.138 \\ \text { DAY CARE SERVICE } & 06 & 03.948 \\ \text { COMMUNITY HEALTH NURSE SERVICE } & 07 & 06.868 \\ \text { "GREAT START" PARENT/CEILD CLASSES } 04 & 03.928 \\ \text { NO ANSWER } & 20 & 13.158\end{array}$

36. DO YOU HAVE A NEED FOR ANY OF THE SERVICES AT IRIS COURT THAT YOU BAVEN'T PARTICIPATED IN YET?

$\begin{array}{lll}\text { ACTIVITIES FOR CHILDREN } & 04 & 03.928 \\ \text { JOB HEALTH FAIR } & 07 & 06.86 \% \\ \text { SOCIAI GATHERINGS } & 04 & 03.928 \\ \text { EMPLOYMENT OFFICE } & 08 & 07.848 \\ \text { "SNACK ATTACK" NUTRITION CLASSES } & 07 & 06.868 \\ \text { DAY CARE SERVICES } & 16 & 15.68 \% \\ \text { COMMUNITY HEALTH NURSE SERVICE } & 07 & 06.86 \% \\ \text { "GREAT START" PARENT/CHILD CLASSES } & 04 & 03.928 \\ \text { NO ANSWER } & 20 & 13.15 \%\end{array}$

37. WHAT CEANGES OR ADDITIONS WOULD YOU LIRE TO SEE IN THE SERVICES PROUIDED IN IRIS COURT?

1. No answer

2. Nothing

3. Activities Parent/Child

. Parking

. Daycare (Complex kids only)

Stop live in of boy/girlfriend

Drapes / Rugs / cleaning

More older people

Nicer people

10. Better maintenance

11. Better assistance for elderly

12. Get rid of roaches

13. Lunch/breakfast for children

$\begin{array}{lll}07 & 08.138 \\ 25 & \vdots & 29.068 \\ 08 & & 09.308 \\ 01 & & 01.168 \\ 06 & & 06.978 \\ 01 & & 01.168 \\ 03 & & 03.488 \\ 02 & & 02.328 \\ 01 & & 01.168 \\ 06 & 06.978 \\ 01 & 01.168 \\ 01 & 01.168 \\ 01 & & 01.168\end{array}$


14. Lower one-way/no parking signs make more visible

15. Nore police patrol

$01 \quad 01.168$

16. Complex people to have first shot

03.488

childcare.

17. Speed bump

18. Fans over stoves

19. Pay washing machines

20. Happiness

21. Playground for older kids

22. Wants to have dogs

23. Screen applicants better

24. Iisten to and include elderly

25. Change name of $\mathrm{Ct}$. to Ivory Iris and Sumner to something more "Grand"

01.168

01.168

01.168

01.168

01.168

01.168

01.168

01.168

01.168

26. Dental services

27. Better organization in activities

01.168

01.168

01.168

01.168

01.168

02.328

01.168

Stop fighting

31. Leave me alone

32. Someone to talk to when you have problems

01

01.168

38. HAVE YOU PARTICIPATED IN THE TENANT ASSOCIATION?

$\begin{array}{llll}\text { YES } & 38 & & 56.718 \\ \text { NO } & 27 & ? & 40.298 \\ \text { NO ANSWER } & 02 & & 02.988\end{array}$


APPENDIX F

NORTH PRECINCT OFFICER SURVEY RESULTS: 1990 AND 1991 
NORTH PRECINCT OFFICER SURVEY / COMPARATIVE RESULTS

FOR 1990 AND 1991

1. SEX

\begin{tabular}{lllll} 
& 1990 & & \multicolumn{2}{c}{1991} \\
MALE & 56 & 928 & 61 & 908 \\
FEMALE & 05 & 088 & 07 & 108
\end{tabular}

2. $\quad$ AGE

\begin{tabular}{lllll} 
& 1990 & & \multicolumn{2}{c}{1991} \\
$21-30$ & 15 & 258 & 21 & 308 \\
$31-40$ & 27 & 458 & 26 & 388 \\
$41-50$ & 15 & 258 & 18 & 268 \\
$51+$ & 02 & 038 & 03 & 048 \\
NO ANSWER & 02 & 03 & 01 & 018
\end{tabular}

3. NUMBER OF YEARS ON POLICE BUREAU.

\begin{tabular}{lllll} 
& 1990 & & \multicolumn{2}{c}{1991} \\
LESS THAN 5 YRS. & 18 & 308 & 27 & 398 \\
$5-10$ YRS. & 21 & 348 & 22 & 328 \\
$11-15$ YRS. & 08 & 138 & 09 & 138 \\
$16-20$ YRS. & 07 & 118 & 07 & 108 \\
$20+$ YRS. & 07 & 118 & 04 & 068
\end{tabular}


4. HOW MUCH FORMAL SCHOOLING DO YOU HAVE?

\begin{tabular}{|c|c|c|c|c|c|}
\hline \multirow[b]{2}{*}{ HIGH } & \multicolumn{3}{|c|}{1990} & \multicolumn{2}{|c|}{1991} \\
\hline & SCHOOL GRAD. & 01 & 028 & 00 & $00 \%$ \\
\hline \multirow[t]{2}{*}{ SOME } & COLLEGE & 23 & 388 & 33 & 478 \\
\hline & $\begin{array}{lll}1 & Y R . & \\
1 & 1 / 2 & Y R . \\
2 & Y R . & \\
2 & 1 / 2 & Y R . \\
3 & Y R . & \\
3 & 1 / 2 \\
4 & Y R . & \\
5 & Y R . & \end{array}$ & $\begin{array}{l}05 \\
01 \\
08 \\
01 \\
04 \\
02 \\
02 \\
00\end{array}$ & & $\begin{array}{l}02 \\
03 \\
12 \\
01 \\
10 \\
03 \\
01 \\
01\end{array}$ & \\
\hline \multicolumn{2}{|c|}{ COLLEGE GRAD. } & 21 & 348 & 22 & 318 \\
\hline \multicolumn{2}{|c|}{ GRADUATE WORK } & 09 & 158 & 07 & $10 \%$ \\
\hline \multicolumn{2}{|c|}{ GRADUATE DEGREE } & 07 & 118 & 05 & 078 \\
\hline \multirow[t]{7}{*}{$\underline{5}}$. & $\underline{\text { RACE }}$ & & & & \\
\hline & & 199 & & & \\
\hline & ASIAN & 00 & 008 & 01 & 018 \\
\hline & HISPANIC & 00 & 008 & 02 & 038 \\
\hline & WHITE & 57 & 938 & 60 & 878 \\
\hline & NATIVE AMER. & 02 & 038 & 01 & 018 \\
\hline & OTHER & 02 & 038 & 02 & 038 \\
\hline
\end{tabular}


6. HOW LONG HAVE YOUR WORKED NORTH PRECINCT?

1990

1991

LESS THAN 1 YR. $07 \quad 118 \quad 14 \quad 208$

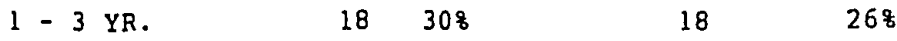

$4-7$ YR. $\quad 15 \quad 258 \quad 17 \quad 258$

$8-11$ YR. $13 \quad 21 \% \quad 12 \quad 17 \%$

12 - 15 YR. $\quad 0305 q \quad 03 \quad 048$

$16-19$ YR. $\quad 00 \quad 008 \quad 03 \quad 048$

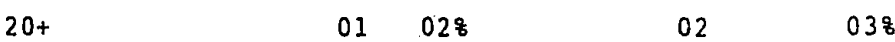

7. HOW DO YOU FEEL ABOUT WORKING NORTH PRECINCT?

\begin{tabular}{lllll} 
& 1990 & & \multicolumn{2}{c}{1991} \\
VERY GOOD & 26 & 438 & 35 & 518 \\
GOOD & 32 & 528 & 22 & 328 \\
FAIR & 03 & 058 & 09 & 138 \\
POOR & 00 & 008 & 02 & 038 \\
VERY POOR & 00 & 008 & 01 & 018
\end{tabular}

8. HOW DO YOU FEEL ABOUT YOUR CO-WORKERS?

\begin{tabular}{lllll} 
& 1990 & & \multicolumn{2}{c}{1991} \\
VERY GOOD & 26 & 438 & 27 & 398 \\
GOOD & 32 & 528 & 32 & 468 \\
FAIR & 03 & 058 & 10 & 148 \\
POOR & 00 & 008 & 00 & 008 \\
VERY POOR & 00 & 008 & 00 & 008
\end{tabular}


9. HOW DO YOU FEEL ABOUT YOUR PHYSICAL WORKING CONDITIONS? (NORTH PRECINCT)

\begin{tabular}{lllll} 
& 1990 & & \multicolumn{2}{c}{1991} \\
VERY GOOD & 01 & 028 & 04 & 068 \\
GOOD & 00 & 008 & 11 & 168 \\
FAIR & 13 & 218 & 21 & 308 \\
POOR & 19 & 318 & 22 & 328 \\
VERY POOR & 27 & 448 & 11 & 168 \\
NO ANS/UNK & 01 & 028 & 00 & 008
\end{tabular}

10. HOW DO YOU FEEL ABOUT YOUR ORGANIZATIONS POLICIES AND PROCEDURES.

\begin{tabular}{lllll} 
& 1990 & & \multicolumn{2}{c}{1991} \\
VERY GOOD & 02 & 038 & 04 & 068 \\
GOOD & 15 & 258 & 28 & 418 \\
FAIR & 25 & 418 & 26 & 388 \\
POOR & 15 & 258 & 08 & 128 \\
VERY POOR & 03 & 058 & 03 & 048 \\
NO ANS/UNK & 01 & 028 & 00 & 008
\end{tabular}

11. HOW DO YOU FEEL ABOUT THE SKILLS YOU HAVE WITB REGARD TO WORKING WITH RESIDENTS TO SOLVE PROBLEMS?

\begin{tabular}{lllll} 
& 1990 & & \multicolumn{2}{c}{1991} \\
VERY GOOD & 10 & 168 & 15 & 228 \\
GOOD & 35 & 578 & 31 & 458 \\
FAIR & 12 & 208 & 22 & 328 \\
POOR & 03 & 058 & 01 & 018 \\
VERY POOR & 00 & 008 & 00 & 008 \\
NO ANS/UNK & 01 & 028 & 00 & 008
\end{tabular}


12. HOW DO YOU FEEL ABOUT THE TIME YOU HAVE WITH REGARD TO WORKING WITH RESIDENTS TO SOLVE PROBLEMS?

\begin{tabular}{lllll} 
& \multicolumn{2}{c}{1990} & & \multicolumn{2}{c}{1991} \\
VERY GOOD & 01 & 028 & 00 & 008 \\
GOOD & 11 & 188 & 12 & 178 \\
FAIR & 24 & 398 & 33 & 488 \\
POOR & 19 & 318 & 18 & 268 \\
VERY POOR & 05 & 088 & 01 & 018 \\
NO ANS/UNK & 01 & 028 & 01 & 018
\end{tabular}

13. HOW DO YOU FEEL ABOUT THE SKILLS YOU HAVE WITH REGARD TO HELPING VICTIMS OF CRIME?

1990

1991

$\begin{array}{lllll}\text { VERY GOOD } & 01 & 028 & 10 & 148\end{array}$

$\begin{array}{lllll}\text { GOOD } & 11 & 188 & 37 & 548\end{array}$

$\begin{array}{lllll}\text { FAIR } & 24 & 398 & 16 & 238\end{array}$

$\begin{array}{lllll}\text { POOR } & 19 & 318 & 03 & 048\end{array}$

$\begin{array}{lllll}\text { VERY POOR } & 05 & 088 & 02 & 038\end{array}$

$\begin{array}{lllll}\text { NO ANS/UNK } & 01 & 028 & 01 & 018\end{array}$

14. HOW DO YOU FEEL ABOUT THE TIME YOU HAVE WITH REGARD TO HELPING VICTIMS OF CRIME?

1990

1991

$\begin{array}{lllll}\text { VERY GOOD } & 00 & 008 & 00 & 008 \\ \text { GOOD } & 09 & 158 & 18 & 268 \\ \text { FAIR } & 27 & 448 & 30 & 438 \\ \text { POOR } & 18 & 308 & 18 & 268 \\ \text { VERY POOR } & 06 & 108 & 02 & 038 \\ \text { NO ANS/UNK } & 01 & 028 & 01, & 018\end{array}$


15. HOW ARE YOU DOING IN BEING POLITE TO PEOPLE?

1990

VERY GOOD

GOOD

FAIR

POOR

VERY POOR
23

29

07

01

01
$38 \%$

$48 \%$

118

028

028
1991

338

488

$17 \%$

018

008

16. HOW ARE YOU DOING IN TREATING PEOPLE FAIRLY?

\begin{tabular}{lllll} 
& \multicolumn{2}{c}{1991} \\
VERY GOOD & 27 & 448 & 30 & $43 \%$ \\
GOOD & 30 & 498 & 37 & 548 \\
FAIR & 03 & 058 & 01 & 018 \\
POOR & 00 & 008 & 00 & 008 \\
VERY POOR & 00 & 008 & 00 & 008 \\
NO ANS/UNK & 01 & 028 & 01 & 018
\end{tabular}


17. WHAT DO YOU THINK IS THE MAJOR CRIME PROBLEM AT THE IRIS COURT HOUSING COMPLEX?

1990

$\begin{array}{llll}\text { A. FAMILY FIGHT } & 20 & 278 \\ \text { B. NO ANS/UNK } & 20 & 278 \\ \text { C. ASSAULT } & 12 & 168 \\ \text { D. DRUGS/GANGS } & 08 & 118 \\ \text { E. USES FORCE TO STEAL } & 05 & 078 \\ \text { F. HOME BROKEN INTO } & 03 & 048 \\ \text { G. RAPE } & 01 & 018 \\ \text { H. VANDALISM } & 01 & 018 \\ \text { I. CAR STOLEN } & 01 & 018 \\ \text { J. CAR BROKEN INTO } & 01 & 018 \\ \text { K. ALL OF THE ABOVE } & 03 & 048\end{array}$

17. $($ CONT)

$\underline{1991}$

A. HOMES BROKEN INTO $05 \quad 06 \%$

B. SOMEONE USES FORCE TO STEAI $05 \quad 06 \%$

C. ASSAULT $13 \quad 14 \%$

D. RAPE $01 \quad 018$

E. VANDALISM $03 \quad 03 \%$

F. CAR STOLEN $01 \quad 01 \%$

G. FAMILY FIGHT $23 \quad 268$

H. CAR BROKEN INTO $02 \quad 02 \%$

I. NO ANS/UNK $\quad 36 \quad 408$

J. NO MORE PROBLEMS $01 \quad 01 \%$ 
18. WHAT WOULD YOU LIKE TO SEE DONE TO IMPROVE LIFE IN THIS COMPLEX? (1990)

A. NO ANS/UNK

$35 \quad 57 z$

B. GET RID OF TROUBLE MAKERS

07

$11 \%$

C. GET RID OF DRUGS

03

058

D. DO COMPLETE BACKGROUND ON

PRINCIPAL RENTERS, EVICT REPEAT

OFFENDERS AND ESTABLISH A PATROT OF IIVE-IN CITIZENS

E. AGGRESSIVE POLICE ACTION AGAINST

DOPE DEALERS SHOULD CONTINUE,

BACKED BY DOWNTOWN AND DA'S

OFFICE.

F. TENANT OWNERSHIP

02

G. REMOVE UNAUTHORIZED PEOPLE

H. MORE RESPONSIVE MANAGEMENT IN CONJUNCTION WITH POLICE.

I. OCCASIONAL BICYCLE/WALKING PATROLS 01

J. A CONTINUED STRONG POLICE PRESENCE (COMMUNITY POLICING)

K. LEARN FROM COLUMBIA VILLA / USE WHAT WORKS AND ADD ON MODIFICATIONS.

L. MORE POLICE

M. MORE JAIL SPACE

N. COMMUNITY UNDERSTANDING

o. QUICKER ACTION REGARDING TENANTS AND TENANTS PROBLEMS.

P. NUKE IT.

Q. BURN IT DOWN.

R. I THINK THE PROBLEM AT THE IRIS COURT APARTMENTS IS GREATLY EXAGGERATED. THE PROBLEMS THERE HAVE BEEN MOSTLY CORRECTED BY MANAGEMENT WITH SELECTIVE EVICTIONS. I BELIEVE IT WOULD BE 
18. CONT. (1990)

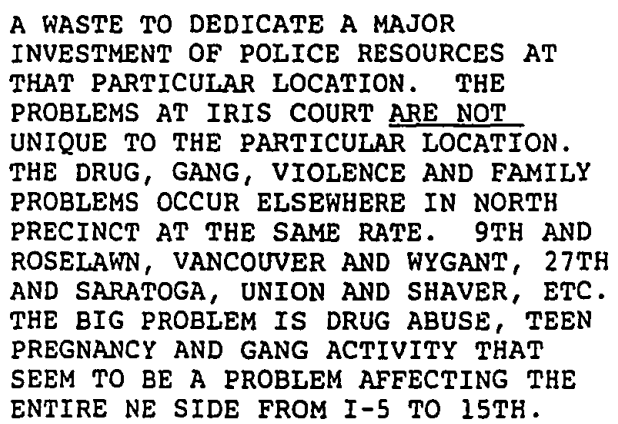

18. WHAT WOULD YOU LIKE TO SEE DONE TO IMPROVE LIFE IN THIS COMPLEX? (1991)

A. POLICE ESTABLISH RAPPORT WITH COMMUNITY

$01 \quad 018$

B. BETTER QUALITY TENANTS

$01 \quad 018$

C. NO ANSWER

48

698

D. TRESPASS ALL GANG MEMBERS, DOPERS, DEALERS.

$02 \quad 038$

E. CONTINUE PRESENT WORK

03

048

F. KEEP OFFICERS INFORMED OF DEVELOPMENTS

G. CURFEW 018

H. PEOPLE TAKING MORE PRIDE IN NEIGHBORHOOD / POLICING OWN PROBLEMS.

I. BOMB IT.

J. TIGHTEN RULES FOR RESIDENTS/KICK OUT VIOLATORS

K. EVICT PEOPLE WHO ALLOW TRESPASSERS TO RESIDE W/THEM.

L. MORE PROGRAMS TO ADVANCE FAMILY STRUCTURE AND AID KIDS.

M. STRICTER MORE CONSERVATIVE GUIDELINES FOR QUALIFICATION 
18. (CONT) 1991
N. INTEGRATION OF OTHER RACES.
$01 \quad 018$
O. EDUCATION FOR RESIDENTS
01
018

19. COMPARED TO YOUR HOME NEIGHBORHOOD, HOW AFRAID ARE YOU TO GO INTO THE IRIS COURT HOUS ING COMPLEX ALONE AFTER DARK?

$1990 \quad 1991$

$\begin{array}{lllll}\text { NOT AFRAID } & 14 & 238 & 21 & 308 \\ \text { SOMEWHAT AFRAID } & 17 & 288 & 18 & 268 \\ \text { VERY AFRAID } & 13 & 218 & 09 & 138 \\ \text { UNK/NO ANS } & 17 & 288 & 21 & 308\end{array}$

20. WHAT IS THE QUALITY OF POLICE SERVICE BEING RECEIVED

BY RESIDENTS IN THE IRIS COURT HOUSING COMPLEX?

1990

VERY GOOD

GOOD

FAIR

POOR

VERY POOR

NO ANS/UNK
08

17

15

02

02

17
138

$28 \%$

258

038

038

288
$19: 1$

12

178

298

06 웅

008

$00 \%$

488 
21. HOW IS THE QUALITY OF HEALTB SERVICE IN THE IRIS COURT HOUSING COMPLEX?

\begin{tabular}{lllll} 
& 1990 & & \multicolumn{2}{c}{1991} \\
VERY GOOD & 00 & 008 & 01 & 018 \\
GOOD & 03 & 058 & 08 & 128 \\
FAIR & 10 & 168 & 04 & 068 \\
POOR & 06 & 108 & 00 & 008 \\
VERY POOR & 04 & 078 & 00 & 008 \\
NO ANS/UNK & 38 & 628 & 56 & 818
\end{tabular}

22. HOW IS CHILD CARE IN THE IRIS COURT HOUSING COMPLEX?

\begin{tabular}{lllll} 
& 1990 & & \multicolumn{2}{c}{1991} \\
VERY GOOD & 00 & 008 & 00 & 008 \\
GOOD & 02 & 038 & 05 & 078 \\
FAIR & 08 & 138 & 05 & 078 \\
POOR & 09 & 158 & 04 & 068 \\
VERY POOR & 04 & 078 & 00 & 008 \\
NO ANS/UNK & 38 & 628 & 55 & 808
\end{tabular}

23. HOW DO YOU FEEL ABOUT THE PEOPLE WHO LIVE IN THE IRIS COURT HOUS ING COMPLEX, COMPARED TO RESIDENTS IN YOUR OWN NEIGHBORHOOD?

\begin{tabular}{lllll} 
& 1990 & & \multicolumn{2}{c}{1991} \\
VERY GOOD & 00 & 008 & 00 & 008 \\
GOOD & 03 & 058 & 07 & 108 \\
FAIR & 12 & 208 & 11 & 168 \\
POOR & 12 & 208 & 10 & 148 \\
VERY POOR & 14 & 238 & 04 & 068 \\
NO ANS/UNK & 20 & 338 & 37 & 548
\end{tabular}


NORTH PRECINCT OFFICER SURVEY $/$ COMPARATIVE RESUI'IS

FOR 1990 AND 1991

1. SEX

\begin{tabular}{lllll} 
& 1990 & & \multicolumn{2}{c}{1991} \\
MALE & 56 & 928 & 61 & 908 \\
FEMALE & 05 & 088 & 07 & 108
\end{tabular}

2. $\quad \underline{A G E}$

$21-30 \quad 15 \quad 25 \%$

$31-40 \quad 27 \quad 458$

$41-50 \quad 15 \quad 258$

$51+\quad 02 \quad 038$

NO ANSWER 02

03

1991

$2130 \%$

26

388

18

268

03

$04 \frac{1}{8}$

3. NUMBER OF YEARS ON POLICE BUREAU.

01

018

3. NUMBER OF YEARS ON

1991

LESS THAN 5 YRS. 18

5 - 10 YRS.

308

27

398

11 - 15 YRS.

348

22

328

16 - 20 YRS.

138

09

138

$20+$ YRS.

$07 \quad 118$

07

$10 \%$

118

04

068 
24. HOW DO YOU FEEL ABOUT THE ON-SITE NANAGER(S) AT THE IRIS COURT HOUSING COMPLEX COMPARED TO OTHER ON-SITE MANAGER (S) AT COMPLEXES YOU SERVE?

\begin{tabular}{lllll} 
& 1990 & & \multicolumn{2}{c}{1991} \\
VERY GOOD & 01 & 028 & 04 & 068 \\
GOOD & 02 & 038 & 05 & 078 \\
FAIR & 11 & 188 & 10 & 148 \\
POOR & 10 & 168 & 00 & 008 \\
VERY POOR & 01 & 028 & 00 & 008 \\
NO ANS /UNK & 36 & 598 & 50 & 728
\end{tabular}

25. WHAT AMOUNT OF TIME HAVE YOU SPENT IN THE IRIS COURT HOUSING COMPLEX SINCE THE SIMMER OF 1989? (CLOSE GUESS)

$\begin{array}{lllll}\text { NONE } & 14 & 238 & 02 & 038 \\ \text { UNDER 1 HOUR } & 07 & 118 & 05 & 078 \\ 1-5 \text { HOURS } & 12 & 208 & 17 & 258 \\ 6-10 \text { HOURS } & 07 & 118 & 11 & 158 \\ 11-15 \text { HOURS } & 02 & 038 & 00 & 008 \\ 16-20 \text { HOURS } & 03 & 058 & 03 & 048 \\ 21-25 \text { HOURS } & 00 & 008 & 02 & 038 \\ 26-30 \text { HOURS } & 02 & 038 & 01 & 018 \\ 31-50 \text { HOURS } & 01 & 028 & 02 & 038 \\ 50+\text { HOURS } & 02 & 038 & 02 & 038 \\ \text { NO ANS/UNK } & 11 & 188 & 23 & 338\end{array}$


26. HOW EFFECTIVE ARE YOU IN WORFING WITH OTHER BUREAUS AND SERVICE AGENCIES TO SOLVE PROBLEMS?

$1990 \quad 1991$

$\begin{array}{lllll}\text { VERY EFFECTIVE } & 06 & 108 & 06 & 098 \\ \text { EFFECTIVE } & 20 & 338 & 31 & 458 \\ \text { FAIR } & 19 & 318 & 23 & 338 \\ \text { POOR } & 09 & 158 & 45 & 078 \\ \text { VERY FOOR } & 02 & 038 & 01 & 018 \\ \text { NO ANS/UNK } & 05 & 088 & 03 & 048\end{array}$

27. HOW DO YOU FEEL ABOUT GETIING INPUT AND FEEDBACK FROM COMOUNITY MEMBERS TO HELP YOU ADJUST THE WAY YOU APPROACH YOUR JOB?

\begin{tabular}{lllll} 
& 1990 & & \multicolumn{2}{c}{1991} \\
VERY GOOD & 04 & 078 & 09 & 138 \\
GOOD & 29 & 488 & 30 & 438 \\
FAIR & 14 & 238 & 19 & 288 \\
POOR & 07 & 118 & 04 & 068 \\
VERY POOR & 05 & 088 & 05 & 078 \\
NO ANS/UNK & 02 & 038 & 02 & 038
\end{tabular}

28 HOW DO YOU FEEL ABOUT YOUR ABILITY TO IMPLEMENT ALTERNATIVE PATROL TECHNIQUES AND STRATEGIES?

1990

1991

VERY GOOD

15

258

128

GOOD

21

348

588

FAIR

15

$25 z$

138

POOR

04

078

07

108

VERY POOR

03

058

.00

008 


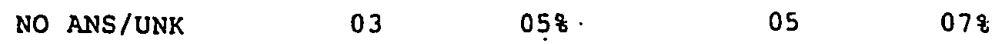

29. HOW DO YOU FEEL ABOUT HAVING A MINI-PRECINCT WITHIN THE IRIS COURT COMPLEX?

\begin{tabular}{lllll} 
& 1990 & & \multicolumn{2}{c}{1991} \\
VERY GOOD & 04 & 078 & 12 & 178 \\
GOOD & 10 & 168 & 27 & 398 \\
FAIR & 14 & 238 & 07 & 108 \\
POOR & 09 & 158 & 04 & 068 \\
VERY POOR & 08 & 138 & 05 & 078 \\
NO ANS/UNK & 16 & 268 & 14 & 208
\end{tabular}

30. HOW DO YOU FEEL ABOUT THE QUALITY OF LIFE FOR NEIGHBORS IN THE

- PATROL DISTRICT THAT INCLUDES THE IRIS COURT COMPLEX?

\begin{tabular}{lllll}
\hline & 1990 & & \multicolumn{2}{c}{1991} \\
VERY GOOD & 00 & 008 & 02 & 038 \\
GOOD & 04 & 078 & 06 & 098 \\
FAIR & 13 & 218 & 17 & 258 \\
POOR & 20 & 338 & 20 & 298 \\
VERY POOR & 06 & 108 & 02 & 038 \\
NO ANS/UNK & 18 & 308 & 22 & 328
\end{tabular}


31. WHAT DO YOU THINK OF THE OUERALL QUALITY OF LIFE IN THIS COMPLEX?

VERY GOOD
GOOD
FAIR
POOR
VERY POOR

NO ANS/UNK

1990

1991

$01 \quad 028$

$01 \quad 028$

00

002

$09 \quad 158$

08

128

23

23

$38 \%$

23

332

10

$16 \%$

13

198

17

288

00

008

25

368 
APPENDIX G

EVICTIONS 
APPENDIX H

TRESPASS LIST 
IRIS/SUIOKER COURT IRESPASS LIST

Pebruary 14, 1992 at $11: 37$ p.e.

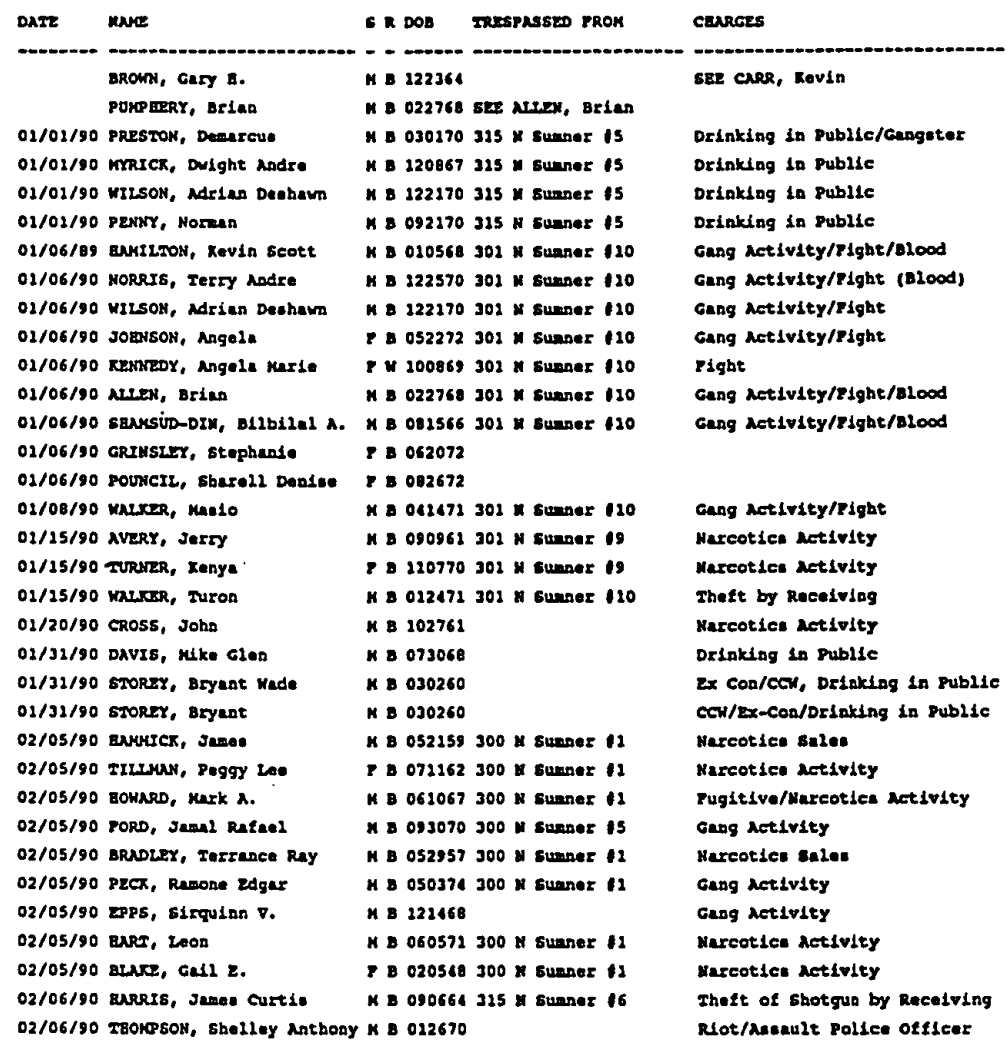

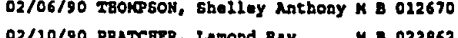

02/10/90 LAKRENCR, Raymond Troy N B 060566302 w sumaer 17

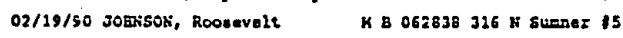

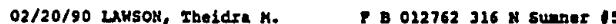

02/20/90 SNEZD, Mene Marie F 031759 J36 \& suaner is

03/06/90 CARR, Kovis W 8122364316 N Sumaner is

03/06/90 sesszon, Renee P 070857

03/06/90 тROKPSON, Ilene 062671315 y Sumner is

0J/19/90 DAvis, Klehael Gleno M B 073058

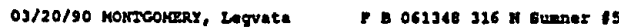

03/31/90 KuRTIK, Iony N D 032170302 N Sumser 17

OQ/25/89 Bans, Prank Jr. $\quad$ K $D 110267$

08/15/89 MORGN, Sherell 220570

08/15/89 parks, Chrietopher H. NB 090163

08/15/Bg EAYLOR, Sham cesereu, K \& 221570301 Y Sumner 12

08/25/89 JOENSON, Leroy Je.

PCs Marijuen/Pugltive

Yequenting

requeatiog

Proquenting/ho Arzeut

Prequenting; Mareotice

Peoquenting

Mercotice Balen/Mo arrent

Proquanting/Ro Arzant

Gang right

Narcotice sulen

Di. con

Narcotice detivity

Marcotice sela.

Mereotica netivity 
IRIS/GUHOTRR COURT TRESPASS 2IST

Pabruary 14, 1992 at 11,37 p.a.

\begin{tabular}{|c|c|c|c|c|}
\hline 22 & KNAE & G R DOS & IRESPASSED TROM & cancess \\
\hline $8 / 26 / 90$ & anress, John c. & $M=221762$ & & Marcotice Netivity \\
\hline $8 / 22 / 99$ & roRd, PhILllp & M 0041265 & & Marcoties Metivity \\
\hline $00 / 22 / 89$ & Lex, Berneo Charlee & $M=062470$ & & Mercoties activity \\
\hline $08 / 27 / 89$ & Eanres, Dlon & $M=090465$ & & Molee violations \\
\hline $08 / 27 / 109$ & JeNnis, Trent 2. & H: 200168 & & Moice violation \\
\hline $08 / 27 / 99$ & anumicx, Lloyd Antene & $H=022369$ & & Molue violation \\
\hline $3 / 27 / 09$ & Cruvropd, curtio 2 . & $M: 030366$ & & \\
\hline /03/89 & STRICRNND, Jeff & $M=102570$ & & Zacapee; Uareotice Aetivity \\
\hline 9/03/89 & GKarR, Doaiko & A $: 030870$ & 315/301 N suaner & Mercotice Netivity \\
\hline $09 / 06 / 09$ & MrLson, Molinde Ang & 80083659 & & PCs II/Gindering Prosecution \\
\hline $99 / 28 / 69$ & wese, Gary hoe & n 123055 & $201 \times$ suaser 110 & Drivlag on sideralk/Gran \\
\hline $1 / 29 / 30$ & PEnN, Kevin Las & M: 032162 & & Marcoties Activity \\
\hline $09 / 26 / 80$ & roruneri, Exie ris & M $: 200258$ & $315 \times$ suanex 03 & gere pous/Activity \\
\hline $20 / 01 / 69$ & Nres, Jame: & M : 030562 & 300 x sunser 12 & \\
\hline $\begin{array}{l}10 / 01 / 89 \\
10 / 02 / 69\end{array}$ & $\begin{array}{l}\text { Nursson, Rolth Lemont } \\
\text { Arres, Murcelle Edward }\end{array}$ & $\begin{array}{l}M=212752 \\
Y: 202049\end{array}$ & 315 in Sunner 12 & $\begin{array}{l}\text { Marcotice Aetivity } \\
\text { Sulp Marcotics Netivity }\end{array}$ \\
\hline $2 / 02 / 69$ & CLomut, Frank Jarcme & K D 061289 & & Sunp varcoties Aetivity \\
\hline $\begin{array}{l}0 / 04 / 69 \\
0 / 04 / 09\end{array}$ & $\begin{array}{l}\text { cark, philip w. } \\
\text { Fucosm, Jaene }\end{array}$ & $\begin{array}{l}n=042563 \\
M=070969\end{array}$ & $\begin{array}{l}315 \times \text { Suaner } 12 \\
100 \times \text { Sumner } 118\end{array}$ & $\begin{array}{l}\text { Aweault II/Police Officer/Riot } \\
\text { Riot/Iatertering }\end{array}$ \\
\hline /29/89 & anoris, Eric & M 021663 & & Mercotice Sale: \\
\hline /o7/ag & CANPAELS, Carl James & $M D 022062$ & $301 \times$ suaner 19 & Harcotice Metivity \\
\hline $1 / 07 / 99$ & METENORE, Amos Lee & N 0.022062 & 301 \& sumner 19 & Harcoties Netivity \\
\hline $1 / 07 / 09$ & POR, Thoodle Rdula & $X D 211453$ & & Karcotiee Netivity \\
\hline $129 / 09$ & Bons, M1111am Jx. & M 022651 & & Hercotles Netivity/root chese \\
\hline /29/8s & Guere, Iavelle & X D 210269 & 302 N Sumner 17 & Conetant Mareotien Activity \\
\hline /29/e9 & ENL, Rensol Anthony & M 8090863 & & Marcotice Activity/Root Chese \\
\hline $1 / 03 / 09$ & senprord, Selwin Terrie & M : 012671 & & Marcotica/Gang Activity \\
\hline $22 / 03 / a 9$ & arothi, Xouln Richard & MD 031070 & 301 N Sumner 110 & Narcotice/Geng Aetivity \\
\hline $12 / 03 / 89$ & LEX, Dorrtek hemar & $N=072768$ & 301 N sumner 120 & Woreotici/Gang Aetivity \\
\hline $103 / 89$ & ROBINSOK, ROblo DOD & * 8012671 & 301 N Sunnex 110 & Narcotica/Gung Activity \\
\hline $1 / 04 / 89$ & METLAND, Eurleyatyne & 8122956 & 100 in sumner it & Prontitution, Drinking \\
\hline $12 / 04 / 89$ & BOWAR, Jeffrey & ห พ 091164 & 400 M Sumner, 11 & Prostitution, Reniet, Drinking \\
\hline $2 / 05 / 89$ & CRUSN, semee 0. & M: 091252 & 302 \& Eunser 19 & Dí con \\
\hline $2 / 05 / a 9$ & ELror, Terry D. & H 8120569 & 325 x Eusnez 12 & Riot/Reneslt Pub saftey officer \\
\hline 190 & CurERON, SOnje R. & $\leqslant 6$ & $300 \times 8$ & Pugitiva/Nareotica Aetivity \\
\hline 109 & BOLIHAS, Douglat I & A. 100761 & 316 W Eumaer 15 & Wanted, Marcotice Aetivity \\
\hline & CENSER, Brenda & $P 008$ & $100 \times$ Bumner 116 & Nercotica Activity. \\
\hline $2 / 11 / 89$ & BukrzToN, oritt & N $: 072660$ & 326 \& Eurger 15 & Marcotice Activity \\
\hline $22 / 31 / 09$ & MrDRENS, Damon LeOD & $K=200367$ & 100 y sumer 116 & DCS \\
\hline $12 / 21 / 09$ & VAuGEN, Nobel tee & M. 102947 & 400 พ Gunner 16 & Des \\
\hline $12 / 12 / 109$ & RuKSOH SR., LDOa & $n=0<2552$ & $1617 \mathrm{NE}$ ri111ngoworth & Nercotice Poesention \\
\hline & euss, Exie & K : 123173 & 100 \& sumnex 116 & mareotice Metivity \\
\hline 2/20/0s & CAVIL, Robert Lee & K : 091376 & 400 H sumper 116 & Marcotles Aetivity \\
\hline & marson, stave sast & ต 1063172 & $100 \times$ Suminar 126 & Wareotlee detivity \\
\hline $12 / 20 / 09$ & Mecool, Joe & M 8082374 & 100 sumger 116 & Marcotice Activity \\
\hline $12 / 10 / 09$ & rgours, Darre12 & 48020460 & 400 * sumper 126 & narcotics Aetivity \\
\hline $12 / 19 / 89$ & LEe, Darrell Zdvard & n 1053059 & $100 \times$ sumser 116 & Harcotles Activity \\
\hline & & P D 073 & 301 N Eunger 120 & Gung Pight \\
\hline $12 / 29 / 90$ & RrcBuroson, colleen & P B 091065 & 301 N sumer 120 & Cung right/5hooting \\
\hline
\end{tabular}


APPENDIX I

TRESPASS GENERAL ORDER 


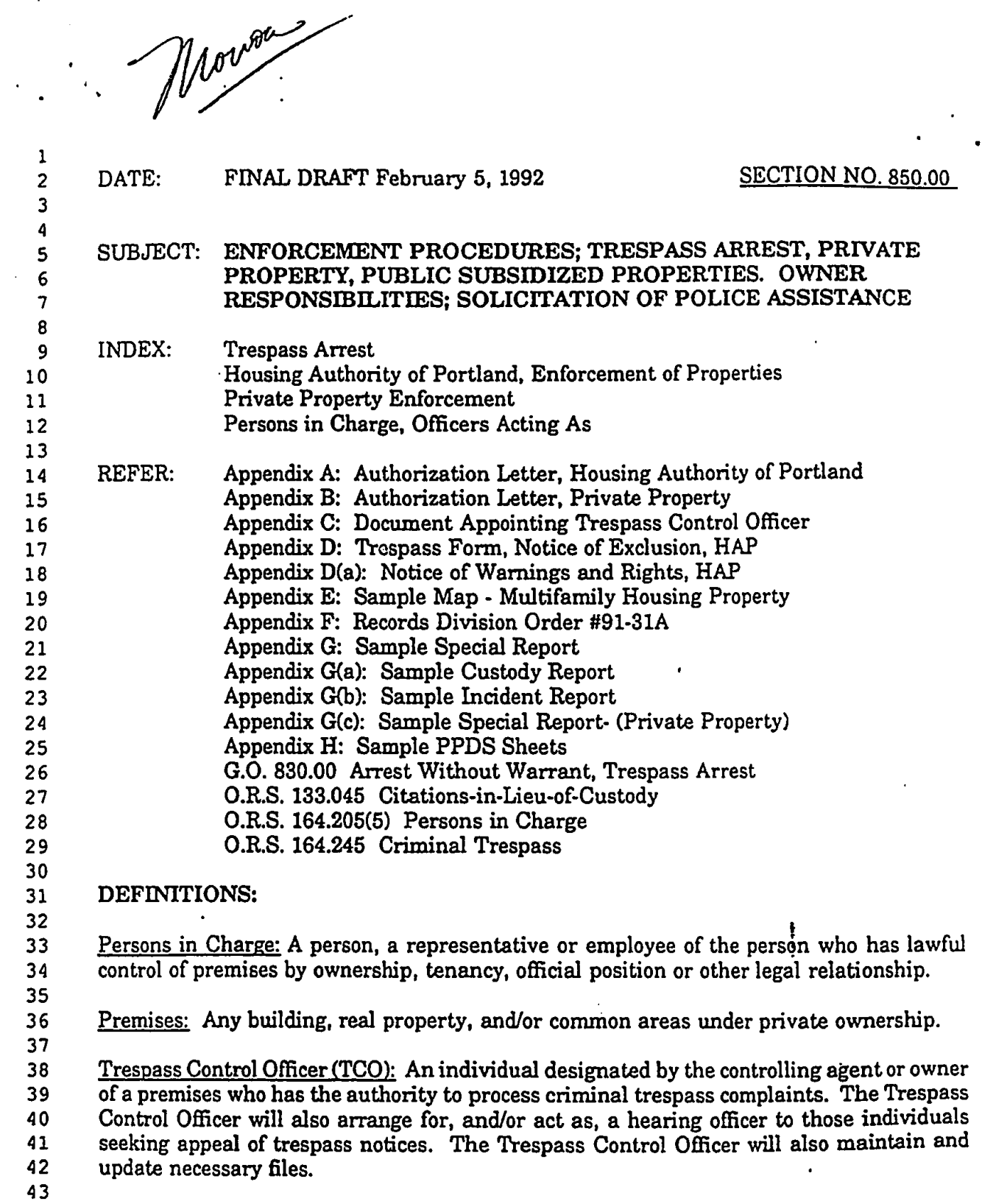


Criteria for Exclusion: A list of reasons compiled by the controlling agent or owner of a premises designed to exclude nonresidents from the common areas of privately owned properties.

Nonresidents: Any person who does not reside in the facility.

Multifamily Housing Properties: A large apartment or other complex providing multihousing units to tenants and generally having common ground areas in between the units; parking lots, courtyards, and play areas designed for use of tenants.

Exclusion Maintenance File (EMF): A file maintained at precinct level on hard copy and/or computer disc, and monitored and updated by a person or persons designated by the precinct commander. This file will reflect the same material as outlined in the TCO's file and pertain to the private properties within the precinct jurisdiction.

\section{INTRODUCTION}

It is known that many occurrences (criminal and non criminal) adversely effect the quality of life on both private property and public subsidized properties. In the past, the members of the Portland Police Bureau have had limited impact on these properties due to private controlling interests or Whinability to locate an owner or designee able to sign a complaint. It is also acknowledged the majority of these offenses are committed by nonresidents of the properties who loiter about the common areas or within a tenant's unit.

Both private property interests and property subsidized by public funds, i.e., Housing Authority properties, have sought assistance to curb the influence of nonresidents and the criminal activity they bring to these properties. These owners and controlling agents have asked for the assistance of the Portland Police Bureau in removing these persons and excluding them from their properties. They have also sought to have these nonresidents arrested under the criminal trespass statutes of this state, should they return.

There are specific procedures that are to be followed by both property owners and police officers to ensure compliance with the law and successful prosecutions. Many of the procedural functions must be initially completed by the owner prior to the Police Bureau's involvement.

While these procedures appear complex, the end result will provide a safer environment on involved properties. It further promotes an enhanced partnership between the police and private property owners, and a reduced call load for the Bureau on those properties historically plagued with serious crime and liveability problems committed by nonresidents.

\section{PURPOSE}


The purpose of this general order is to outline the Bureau's policy and procedures related to the exclusion of nonresidents from private property or public subsidized properties and to ensure the enforcement of those exclusions through criminal trespass arrests.

\section{POLICY}

Members of the Portland Police Bureau may act on behalf of private and public subsidized property owners if the procedures and criteria described in this general order have been established by the property owner before the Bureau members act. These procedures will specifically detail how officers are authorized to act as "Persons in Charge" on private property, as defined in ORS 164.205 (5), and will only apply to the enforcement of trespass procedures on nonresidents under ORS 164.245.

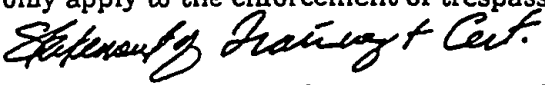

Members are reminded that landlord tenant laws apply in all cases involving tenants, and that landlords should be encouraged to follow the established procedures for eviction (FED, 24 and 72 hours, etc.).

Nothing in this order removes an officer's ability to act when dealing with other criminal matters observed on private property during the course of their duties.

\section{PROCEDURES}

\section{LANDLORD/OWNERAGENT IN CHARGE RESPONSIBILITIES:}

1. The owner or agent in charge of a property (legally designated as such) should reassert control over all areas deemed common areas within the complex; i.e., laundry rooms, common courtyards, private sidewalks, etc. This should be specifically detailed in all rental contracts and leases. This is know as the "Lease Enabling Provision." The assertion of control by owner (usually left out of leases) is to ensure the owner is the "person in charge of these common areas under O.R.S. 164.205 (5).

In addition to the lease enabling procedure, landlords should also include an enabling procedure sufficient to prohibit individuals from establishing residency without prior landlord approval.

An example of a lease enabling provision is:

The (property corporation, landlord or owner's name) retains control over any common areas of the (name of property) for the purposes of enforcing state trespass laws and shall be the "person in charge" for that purpose as that phrase is defined at ORS 164.205 (5). 

ENFORCEMENT AND ARREST - PRIVATE AND PUBLIC
PROPERTIES
G.L

Pq

The addition of this provision to the lease or contract must apply to all new tenants. In order to ensure current tenants are also notified of the owner's claim to the common areas, the owner or their agent should have all current tenants sign a similar provision. They will also have to follow any and all in-house and possible statutory rules for changing leases, contracts, etc.

In that this suggested procedure may effect the rights and obligations of the parties in the existing lease/rental agreements, landlords should always be referred to their private attorney for any review of amendments or enabling provisions to the new lease/rental agreements.

2. The landlord may enable the manager to be the "Person in Charge" for trespass purposes alone. If police officers are to be allowed to make arrests for trespass on behalf of the owner, the owner or their designee must empower the Bureau's police officers to also act as "Persons in Charge" upon their property for the purpose of enforcing trespass laws. This is to be done by a formal letter written to the Chief of Police or Precinct Commander authorizing the officers of the Bureau to act in the described manner. (See Appendix A and B as examples.)

3. The property owner or their agents will include, along with the above letter, a Criteria For Exclusion agreed to by the owner as grounds to exclude nonresidents from their property. This criteria can include a variety of obnoxious, violent, or dangerous activity. It should not, however, be so limited in scope as to be ineffective in addressing the nonresident's behavior these procedures are to address. (See Appendix A and B.)

4. The property owner or their agents will then assign a Trespass Control Officer (TCO). This assignment will consist of a formal document authorizing a particular person, or. behalf of the owner, to act as the TCO. The TCO will process the exclusion forms usually on site or at a local office, and ensure that a current file is maintained o: excluded persons. The TCO will also receive appeal requests by excluded parties. The TCO will notify the precinct when an appeal on specified exclusion is pending. The TCC will also notify the appropriate Bureau members of any persons excluded from the property that were successful in their appeal process. The notification by the TCO ts the person controlling the precinct EMF file must be by telephone within 48-72 hour: followed by a letter to the precinct confirming any modifications or voiding of the exclusion. The successful appellant must not be allowed back onto the property for fiv (5) days from the date of action on the appeal to allow file updates. These notification: will always be the responsibility of the landlords or their designee.

5. The owner or their designee will provide a polaroid camera, a supply of trespass form and a place where a list of current excluded persons can be posted at each properts They will also supply detailed maps of their properties. 
ENFORCEMENT AND ARREST - PRIVATE AND PUBLIC PROPERTIES

\section{POLICE OFFICER RESPONSIBIITIES:}

\section{Exclusion Process}

1. When an officer responds to a participating property and has reasonable grounds to believe that a nonresident is or has been on the private, common property and is violating or has violated the criteria for exclusion, the officer is empowered to contact the nonresident and advise them of the violation.

2. The officer is then empowered to complete the exclusion form specifically detailing the justification for the exclusion.

A. Arrests for Offenses and Issuance of Exclusion Form When making an arrest for an offense, the officer will complete the necessary reports (Custody, Incident, etc.) If the officer decides to exclude the person as well, a Special Report outlining the exclusion for each person arrested will be completed and attached to the exclusion form. The officer will forward two copies of the Special Report and Exclusion Form to the complaint signer, the person assigned to the precinct EMF and the private property's TCO.

\section{B. Exclusions Issued Without Arrests}

In these cases an officer will file a Special Report and attach the Exclusion Form with the same distribution above. Officers may exclude multiple persons on one Special Report.

\section{Report Requirements}

In each Special Report written concerning the original exclusion, the officer will write in the "Location of Occurrence" box only the landmark designation, e.g., HAP Maple Mallory or HAP Iris Ct. If on private property otber than a HAP property, the landmark designation will be "PPE (name of complex)", e.g. PPE Piedmont Plaza. PPE will be the designation for Private Property Exclusion. (Refer to Appendix $\mathrm{G}(\mathrm{c})$. Officers will not include the mailing address in the report.

In addition, when coding the excluded person on the original SPECIAL REPORT, the officers should use the code EX in place of SB or Al, etc. (Refer Appendix F and G.)

In all other subsequent reports related to the exclusion, (e.g., trespass arrest with Custody and Incident Reports), the mailing address is to be used rather than the landmark designation. Additionally, officers should make an effort to refer the trespass arrest to the original exclusion case number. (Refer Appendix $G$ [a] and $G$ [b].) 
ENFORCEMENT AND ARREST - PRIVATE AND PUBLIC
PROPERTIES $\quad \begin{array}{r}\text { G.O. new } \\ \text { Page } 6\end{array}$

These reporting procedures will standardize PPDS data processing and provide clear and concise computer printouts. This becomes important when determining who is excluded from a property. It is also necessary for the timely updating of files and site lists for both officers and managers.

3. The officer will then provide the excluded person a map of the property he or she is excluded from. (This is to ensure that there is no confusion later as to where the individual was not allowed to return.)

4. The officer will take a photograph of the excluded person and include it with a copy of the exclusion form for the on-site office (usually the manager's office). The officer will notify the excluded person of their right to appeal the exclusion (which is noted on the back of the form:)

\section{TRESPASS ARREST PROCESS}

(Refer General Order 830.00 Criminal Trespass Arrest Without Warrant.)

1. If an officer observes a person known to be excluded from a property, a criminal trespass arrest may be made. The officer will process the trespass arrest in the usual manner with the following additions:

A. The officer will attach a copy of the properties map to the report. An (X) will be placed on the map specifically showing where the person was on the common property at the time of the arrest.

B. Copies of the reports will be forwarded to the complaint signer, EMF and TCO.

(NOTE: This person has been excluded from the common areas on private property under the new authority of a "Person in Charge" for this private property. Therefore, the person can only be arrested for criminal trespass if they are trespassing on that private property. If the individual is on a public street or public sidewalk adjacent to the private property, an arrest in not lawful.)

\section{RECORDSDATA PROCESSING REQUIREMENTS}

1. The Records Division will make the necessary entries and assign PPDS offense codes. (Refer Appendix F.)

2. Officers can retrieve the information from PPDS on excluded persons by accessing the "Address Search" format and runnin; the landmark name, e.g., Housing Authority of Portland Iris Court or Housing Authority of Portland Maple Mallory or a private property landmark that will be Reignated in PPDS as Private Property - name of 


\section{ENTORCEMENT AND ARREST - PRIVATE AND PUBLIC PROPERTIES}

G.O. new Page 7

apartment. The "name of apartment" will be decided upon at the time the private property signs up for these procedures. The name chosen needs to remain consistent for data entry and inquiry.

\section{PRECINCT RESPONSIBILITIES:}

1. Each precinct will maintain an Exclusion Maintenance File (EMF). The captain will designate a specific person for this task.

A. The file will include every exclusion for a specific property.

B. The EMF will be updated to reflect any exclusions which are expunged by an appeal process, as notified by the TCO.

C. When requested, the EMF may be printed daily for officers involved with specific properties. This list should be sent to, and maintained at, the on-site office of the property in question.

D. If desired, the EMF may be put into the precinct personal computer for ease of retrieval and updating.

E. The EMF designee will maintain contact with the TCO to ensure that a current list is maintained.

F. The EMF designee will maintain contact with the complaint signer to ensure their list is current.

G. The EMF designee will forward copies of successful appeals to the Records Division for PPDS update. The EMF designee will also write a Special Report for all insufficient cases in order to clear the involved persons from the PDS exclusion file.

2. The precinct may wish to pursue involvement in the appeals process, as outlined by the owner of the property and carried out by the TCO.

3. The precinct commander will create a return letter to any property owner who requests to use these procedures. The letter will include:

A. The names of the people assigned in the precinct to coordinate with the owners TCO.

B. A request to have the property owner's private attorney review these matters.

C. A notice that any civil issues raised by these procedures are the responsibility of the owner. 


\section{ENFORCEMENT AND ARREST - PRIVATE AND PUBLIC}

\section{PROPERTIES}

G.O. new

Page 8

\section{COMPLAINT SIGNER RESPONSIBILITY}

1. The complaint signer will maintain foundation files of all involved properties to include:
A. A letter of empowerment authorizing Portland Police Bureau officers to act as "Persons in Charge" of particular property sites for the purpose of enforcing criminal trespass laws.
B. A letter of declaration outlining the criteria for exclusion.
C. A legal designation by the property owner assigning a Trespass Control Officer.
D. A return letter by the precinct commander.
E. Maps of all involved properties.

2. The complaint signer will file all copies of the Custody, Incident or Special Reports with their corresponding exclusion reports.

3. The complaint signer will maintain a list of excluded persons for each property.

4. The complaint signer will maintain contact with the precinct person in charge of the EMF to ensure they have the same updated lists.

5. The Complaint Signer can sign the necessary complaints for trespass arrests by Bureau officers when such a process has been set up with the District Attorney's Office.

6. The Complaint Signer will send to the Deputy District Attorney two (2) copies of:

A. The foundation papers (see preceding).

B. The original exclusion form and the supporting police reports.

C. The current trespass reports.

D. A copy of the property map marked $(X)$ where the arrestee was at the time of arrest.

TOM POTTER

Chief of Police

Wayne Inman

TP:DG/bd

Assistant Chief of Police

Originator: Neighborhood Response Team 


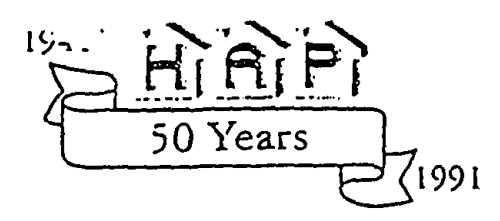

\section{HOUSING AUTHORITY OF PORTLAND}

135 S.W. Ash Street

Portiand, OR 97204

(503) 228-2178 Fax \# (503) 228-4872 TOD \# (503) 226-6095

APPENDIX A

G.0. 850.00

PAGE 3

July 9,1991

Tom potter, chief

portland police. Bureau

1111 SW Second Avenue

Portland, OR 97204

Re: Trespass Enforcement on Housing Authority Property

Dear chief potter:

We have made an addition to our "Criteria for Exclusion. " It is regarding consuming or possessing alcoholic beverages and is number $g$ on the enclosed revised list.

Thank you for the continuing cooperation of you" and your department in these matters.

sincerely,

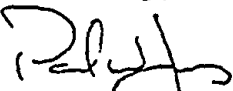

paul w. Johes

Trespass Control officer

$5741 R$

CC: Officer Daye Grady

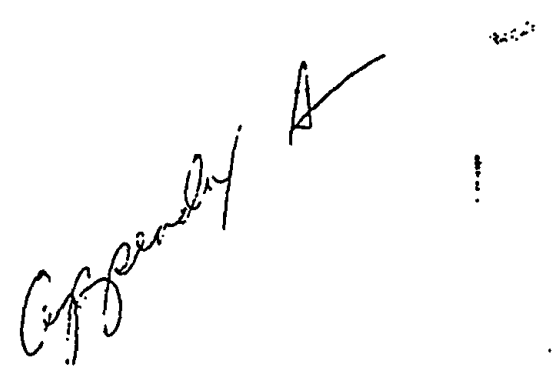


APPENOIX A

G.0. 850.00

PAGE 4

CRITERIA FOR EXCLUSION FROM HAP PROJECTS

Any non-resident will be directed to leave and will be barred from returning to any HAP development within which that person:

1. Makes unreasonable noise;

2. Engages in fighting or in violent or threatening behavior:

3. Substantially interferes with any right, comfort or convenience of any HAP resident or employee;

4. Engages in any activity which constitutes a criminal offense;

5. Engages in any activity involving firearms, illegal drugs or violence;

6. Damages, defaces or destroys any property belonging to HAP, or any HAP resident or employee;

7. Litters on any BAP property:

8. Drives in a careless or reckless manner; .

9. Consumes or possesses an open container of any alcoholic beverage on the common areas without being accompanied (meaning actual physical presence) by a Resident of that development or an adult family member of the Resident's household; or

10. Engages in gang activity, including but not limitedito:

a. wearing clothing, jewlery, or tattoos unique to gang affiliation (color alone is not sufficient to establish gang affiliation):

b. grouping to show gang affiliation or to intimidate rival gangs or tenants; or

c. claiming gang membership.

Any person who fails to leave the property after being directed to do so, or who returns to the property after being given such direction, will be subject to arrest and prosecution for Criminal Trespass under ORS 164.245.

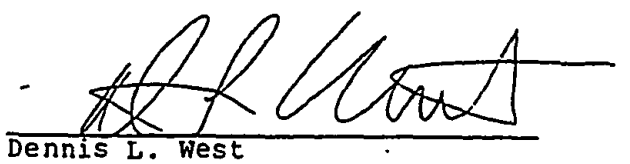

Executive Director

Housing Authority of portland July 9, 1991

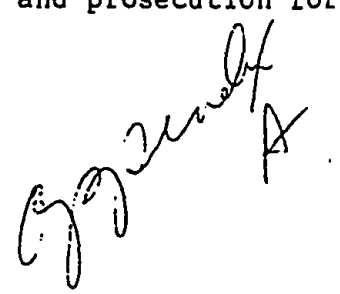

$3167 R$ 
APPENDDX B

G.O. New

7/9.1

ANYWHERE, USA Inc.

ANYWHERE, USA OOOOO-0000

Date

Captain

Portland Police Bureau

Precinct Address

Portland, OR 97203

Dear Captain

Subject: Trespass Enforcement on (Name of property concern)

On behalf of the owner, (Name of owner) as the designated licensee of the managing entity, (Name of company/corporation), this letter will serve as authorization for officers of the Portland Police Bureau to act as agents of (Name of company/corporation), for the purpose of giving trespass notices to, and enforcing trespass laws thereafter against, nonresidents who meet the "Criteria for Exclusion" enclosed with this letter. Officers will be considered a "person in charge", as defined in ORS 164.205 (5).

The current manager of (Name of property) is (Name of manager). (Name of manager) and any designee that she may appoint, should be considered the "person in charge" for criminal trespass purposes (along with officers when acting on their own initiative). In each manager's office will be kept for your officer's use, a Polaroid camera, film, a supply of notices provided by your department, a system for filing notices, and an updated list of residents.

Thank you for your assistance in this matter.

Sincerely,

Property Manager

Enclosure 
APPENDIX B

G.O. New

$7 / 91$

Page 2

\section{CRITERIA FOR EXCLUSION FROM (NAME OF PROPERTY)}

Any nonresident will be directed to leave and will be barred from returning to any property within which that person:

1) Makes unreasonable noise;

2) Engages in fighting or in violent or threatening behavior;

3) Substantially interferes with any right, comfort or convenience or (Name of property) resident or employee;

4) Engages in any activity which constitutes a criminal offense;

5) Engages in any activity involving frearms, illegal drugs or violence;

6) Damages, defaces or destroys any property belonging to (Name of property) or (Name of property) resident or employee;

7) Litters on (Name of property) property; or

8) Drives in a careless or reckless manner;

9) Engages in gang activity. (This should be specifically outlined. See H.A.P. example.)

Any person who fails to leave the property after being directed to do so; or who returns to the property after being given such direction, will be subject to arrest and prosecution for Criminal Trespass under ORS 164-245.

Tenant

Tenant

Date 


$$
\text { A.rixind" } x
$$

RE SOLUTION 90-02-03

APPOIHTING TRESPASS COHTROL OFFICER

KHEREAS, the Executive Director of this Housing

Authority pubiished "Criteria for Exclusion from HaP Projects"

on or about line 9, 1989, a true copy of which is attached

hereto; ano

KHEREAS, individuals who are not lessees or members

of a lessee househoid may enter or remain unlawfully in or upon

premises of this Housing Authority by the commission of the acts

described in the Criteria for Exclusion from HAP Projects; and

HHEREAS, such activities constitute criminal

trespass pursuant to the $I a H$ of the State of Oregon; and

KHEREAS, it is in the best interest of this Housing

Authority that one individual have administrative control over

HAP's activities as they respect criminal tresipass; and

KHEREAS, Paul Jones holds the position as the

Housing Authority's "Evictions Specialist." and is qualified to

administer this authority's criminal trespass activities;

HOK, THEREFORE, BE IT RESOLYED BY the Housing

Authority of Portland that:

1. As an additional assignment, Paul jones is hereby

designated as the Trespass Control Officer of this Hopsing Authority and directed to authorize appropriate offickrs of Multnomah County and the city of Portland to act as agents of this Housing Authority for the purpose of giving notices of trespass and thereafter enforcing the trespass laks of the state of Oregon against non-residents of the Housing Authority.

2. Paul Jones is authorized and directed to prepare and maintain all correspondence and records with respect to criminal trespass occurring on Housing Authority premises.

3. Paul Jones is hereby designated the custodian of all records respecting tresspass activities upon premises of this Housing Authority for purposes of making those records ... - -...ribint tn ORS 192.410 - 192.505 . 


$$
\text { threndix }
$$

Resolution 90.02 .03

Page two

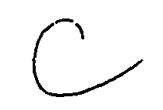

4. Paul Jones employment relationship and

compensation are to remain unchanged except as specifically

provided herein.

5. The officers of this Housing futhority and the said

Paul Jones are authorized and directed to do all things

necessary to implement this resolution.

Dated: February 21,1990

$$
\begin{gathered}
\cdots, \cdots \\
, \cdots, \quad \vdots
\end{gathered}
$$

Attest: ,
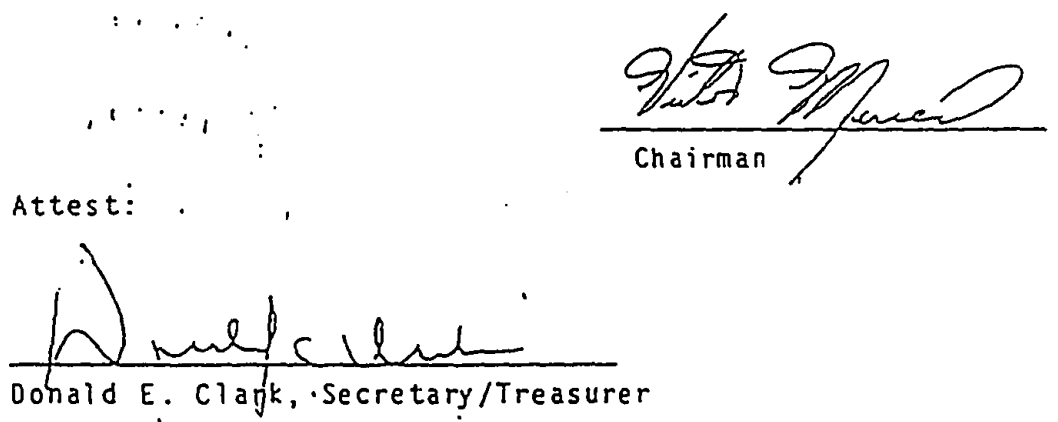

STATE OF OREGOH
COUNTY OF MULTHOMAH

On February 21, 1990, in Portland, Multnomah County, Oregon, before me, Notary Public in and for the State of Oregon,
personally appeared Victon Merced and Donald E. Ciark. each personaliy kriown to me, and each known to me to be the persons described in and who executed the foregoing resolution, and each acknokledged to me that he executed the same; and being by me duly storn, did depose and say that he, victor Merced

is the Chairman and he, Donald E. Clark, is the Secretary, of the Board of Commissioners of the Housing Authority of Portiand. February, 1990 Subscribed and sworn to before me on this $27 \mathrm{st}$ day of

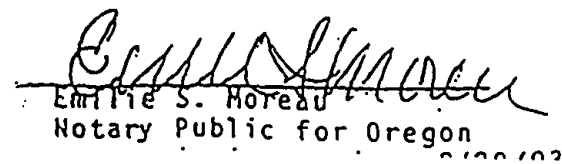


APPENDLX D

G.O. New

i/91

\section{NOTICE OF EXCLUSION \\ HOUSING AUTHORITY OF PORTLAND \\ NOTICE OF WARNING AND RIGHTS (ON BACK)}

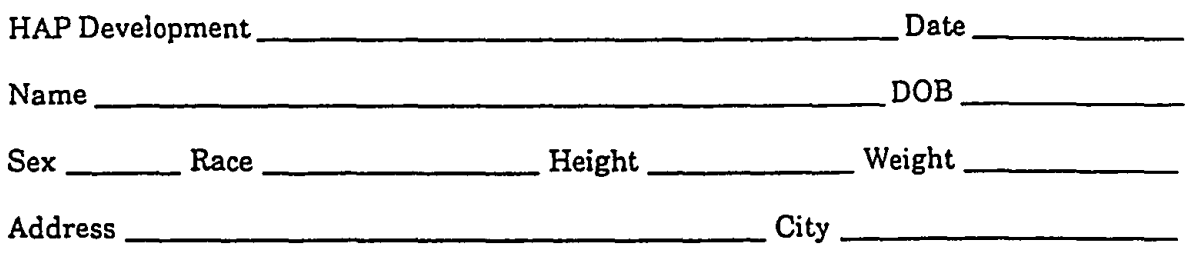

Basis for exclusion (state actions which violated one or more Criteria for Exclusion, including date, time, location). If police/sheriff's report filed, indicate File Number below, and this narrative can then be very brief:

,

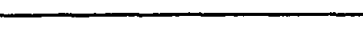
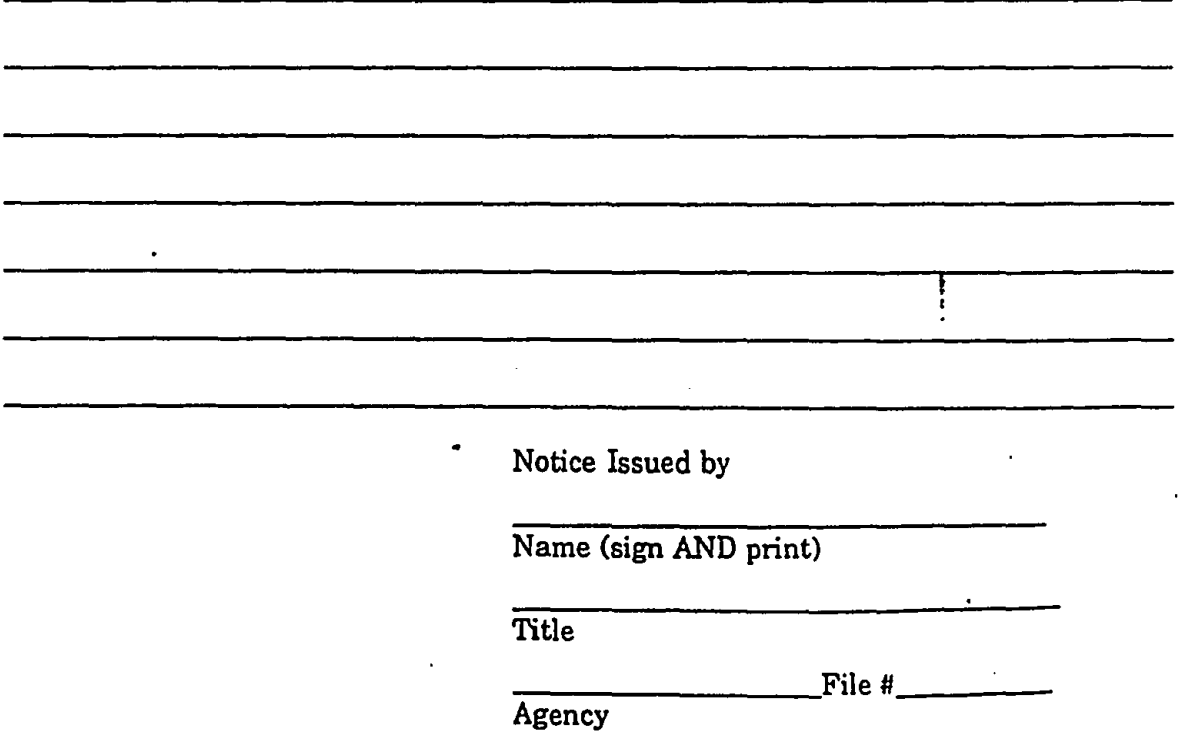

Original: On-Site Office; Yellow: Trespass Control Officer; Pink: Issuer; Goldenrod: Subject 5221R 
APPENDLX D

G.O. New

$7 / 91$

Page 2

\section{NOTICE OF WARNING AND RIGHTS}

1. This is your notice that you are prohibited from entering or remaining on the common areas of the designated HAP property for any reason whatsoever.

2. To enter or remain on the designated property may result in your arrest for Criminal Trespass (ORS 164.245).

3. You may appeal your exclusion. To do so, you must submit a written request, along with a copy of this form, within seven (7) days to:

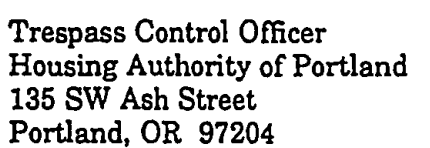

4. You may apply for a temporary waiver of this exclusion. To do so, you must submit your request, including the reasons which you feel justify a waiver, in writing to:

For exclusions from Columbia Villa/Tamarack: Area Manager

Columbia Villa/Tamarack

8920 N. Woolsey Ave.

Portland, OR 97203

All other HAP properties: Trespass Control Officer

Housing Authority of Portland

135 SW Ash Street

Portland, OR 97204

5. After one year from the date of this exclusion notice, you may apply in writing to the appropriate person listed in $\$ 4$ for reconsideration of your exclusion.

6. This exclusion remains in effect during any appeal, request for waiver or request for reconsideration and is only lifted by written notice from the Trespass Control Officer or a member of HAP Management Staff. 


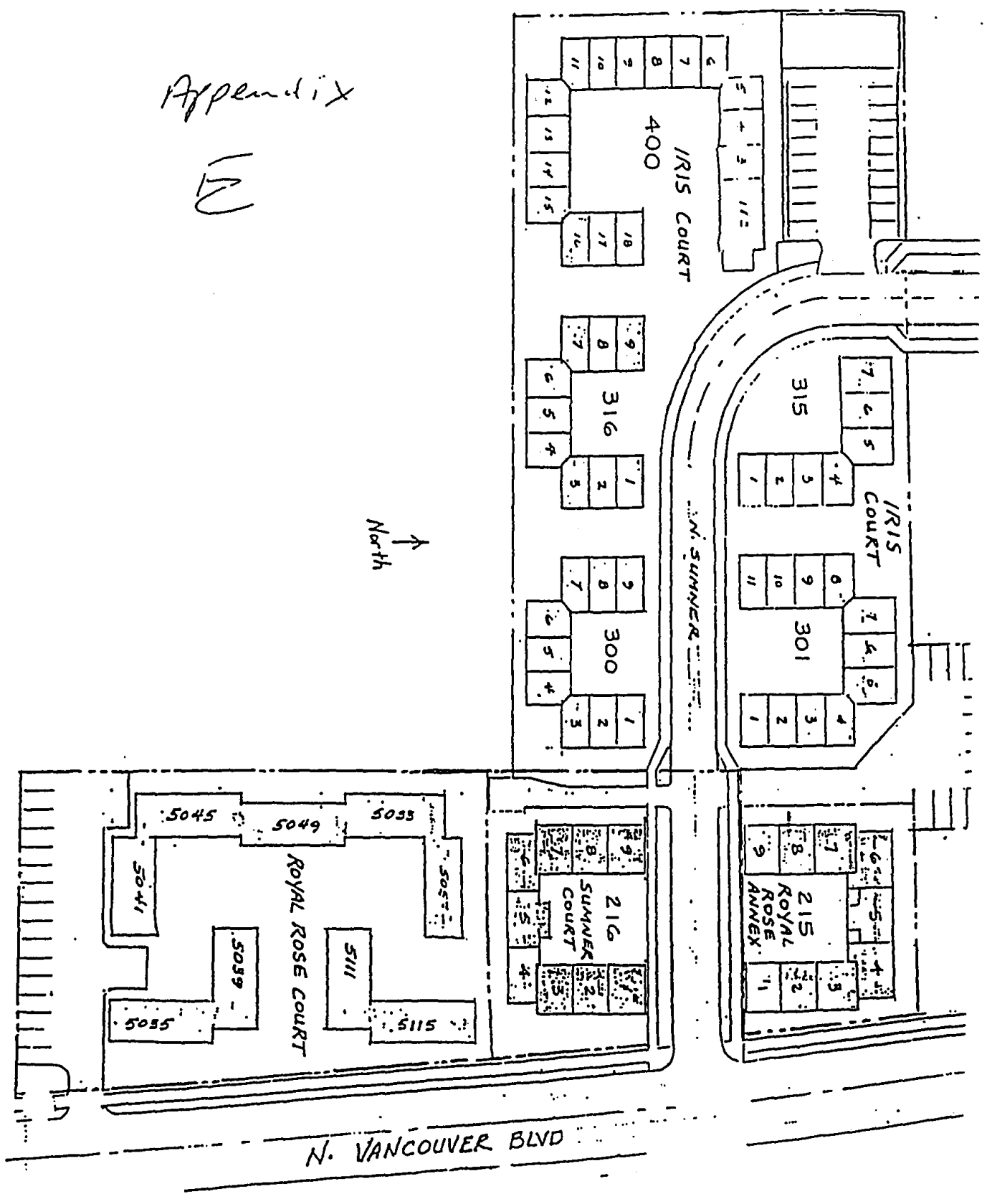


R E C O R D B D I V I B I O N

BOREAU OP POLICE PORTLAND, OREGON

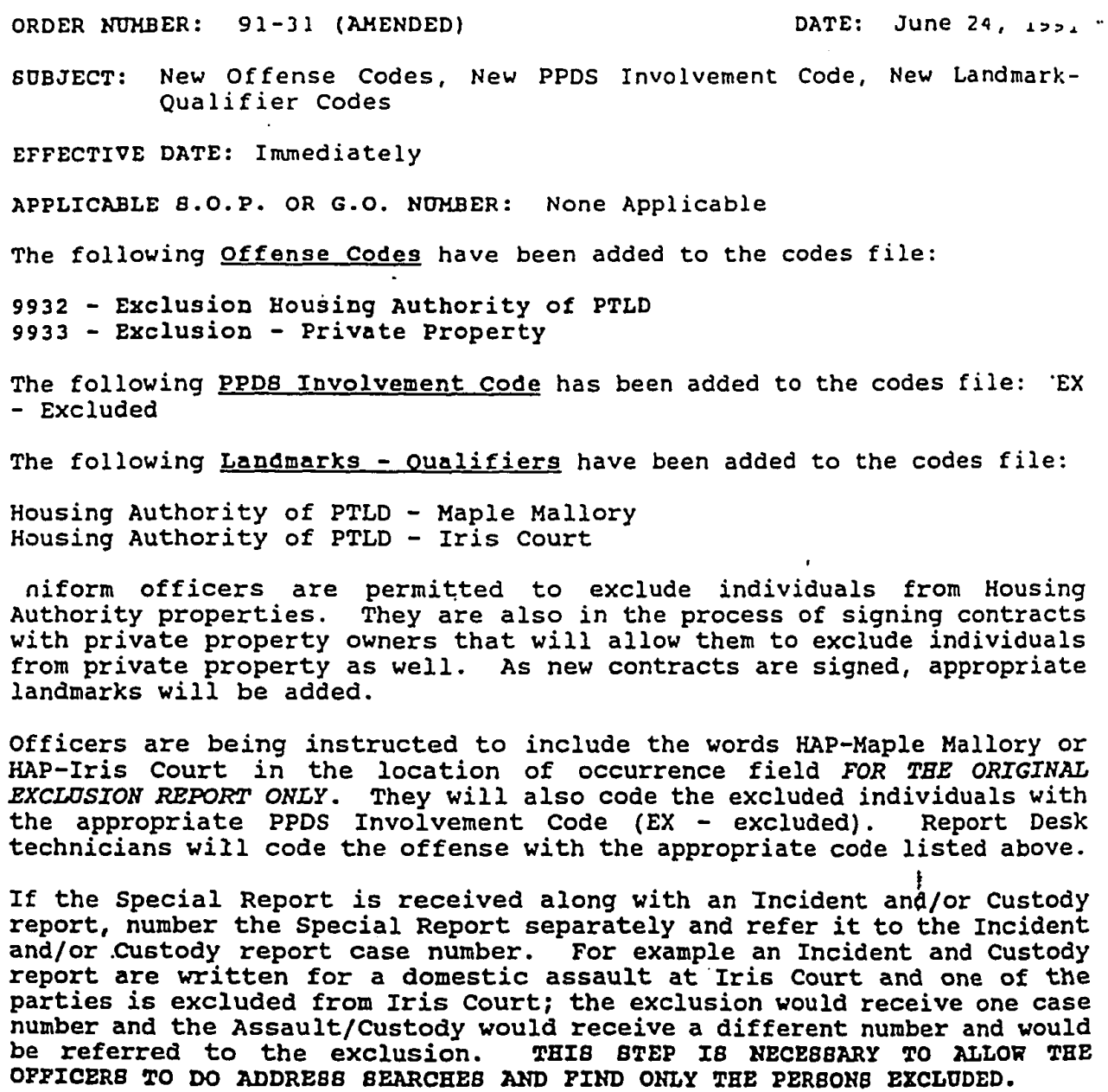

officers are being instructed to include the words HAP-Maple Mallory or HAP-Iris Court in the location of occurrence field FOR TBE ORIGINAL EXCLOSION REPORT ONLY. They will also code the excluded individuals with the appropriate PPDS Involvement Code (EX - excluded). Report Desk technicians will code the offense with the appropriate code listed above.

If the Special Report is received along with an Incident and/or custody report, number the Special Report separately and refer it to the Incident and/or custody report case number. For example an Incident and custody report are written for a domestic assault at Iris court and one of the parties is excluded from Iris Court; the exclusion would receive one case number and the Assault/Custody would receive a different number and would be referred to the exclusion. THIB BTEP IB NECEBBARY TO ALLOF TEE OPFICERB TO DO ADDRESB BEARCHEB AND PIND ONLY TIEE PERBONB EXCLDDED.

Entry technicians will enter the Exclusion Report using the appropriate LANDXEARK.

411 Incident and Custody reports will be entered with tho address listed BEY WILL NOT BE BNTERED BY LANDMARK. 
APPENDIX J

SNACK ATTACK NUTRITION PROGRAM 
NEIGHBORHOOD PARTNERSHIP FUND

IRIS COURT COMMUNITY POLICING DEMONSTRATION PROJECT

Submitted For

HUMBOLDT NEIGHBORHOOD ASSOCIATION

NOVEMBER 20，1990-DECEMBER 19，1991

Report Compiled BY

Caroline Cannon

Janice Broome

OSU Extension Agent,

Multnomah County

Adult/EFNEP Program

$(254-1500)$

OSU Extension Agent

Multnomah county

4-H/EPNEP Program

$(254-1500)$

CONTACT PERSON:

Captain Charles Moose

Portland Police Bureau

$(248-5720)$

PROJECT COOPERATORS:

OSU Extension Service, Multnomah County

Fousing Authority of Portland

Portland Police Sunshine Division

Humboldt Neighborhood Association

Iris court Tenant Council

Iris court Adult volunteers 
EXTENSION SER VICE Multnomah County Office
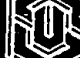

OREGON

STATE

UNIVERSITY

211 SE BOth Avenue Porclend, Oregon $97215 \cdot 1597$

Telephone

$503 \cdot 254 \cdot 1500$

Fax

$503 \cdot 252 \cdot 3598$
January 31,1992

Northeast Coalition of Neighborhoods

Ms. Edna Robertson

4815 NE 7th Ave.

Portand, OR 97211

Dear Ms. Robertson:

Enclosed is a copy of the final repor to the Neighborhood Partnership Fund for the Iris Cour Community Policing Demonstration Project-Nutrition

Education Program which was sponsored through the Coalition and the Humboldt Neighborhood Association.

On behalf of Caroline Cannon, Ext Agent-Nutrition and Jarice Broome, Ext. Agent-Youth Nutrition, I want to thank the Coalition, the Humboldt Neighborhood Assn. and the Porland Police Bureau for your suppon in this important project.

OSU/Multnomah County Extension is proud that we can help the Iris Court Community and our broader local communities with practical education that helps people to become more self-sufficient Fund.

A copy of the report is being sent to the Neighborhood Partnership

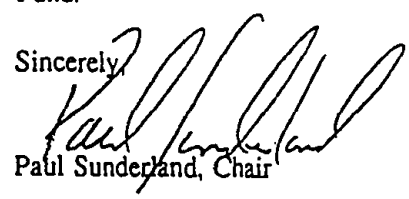

cc:

Ed McNamara, Dir.NPF

Capt. Charles Moose
¿ EXTENSION

Agriculture, Home Economics, 4.H Youth, Forestiy, Commusity Devel meap, Fitrey, and Exteasion Sea Grast Programs Oregon Srate Univers United States Departeasion Sea Grant Programs. Oregon Srier cooperas The Extensios Department of ABriculture, and Oregoo conatier cooperas 
Prepared by: Cezoline Cannon/Jạnice Brcome Date:

$\operatorname{3an}, 30,1992$

FINAL PROJECT REPORT

PROJECT TITLE: Nutrition EXucation Program uiti Iris Court Conmunity Policing

SPONSOR: $\quad \because$ Demonstration Project

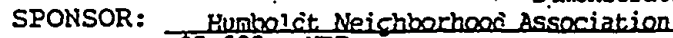

$\$ 2,600-\mathrm{NPF}$

BUDGET: 1,300 -In- $\mathrm{Y}$ ind $\quad$ ACTUAL EXPENDITURES: $\$ \$, 812.17$ Plus $\$ 12,262$ con-

trikuted by OSU E:t. For staff time, office spt.

DATES OF PROJECT: Nov. 20, 1990-Dec. 19, 1991

PROJECT DESCRIPTION AND GOALS:

see attacheo

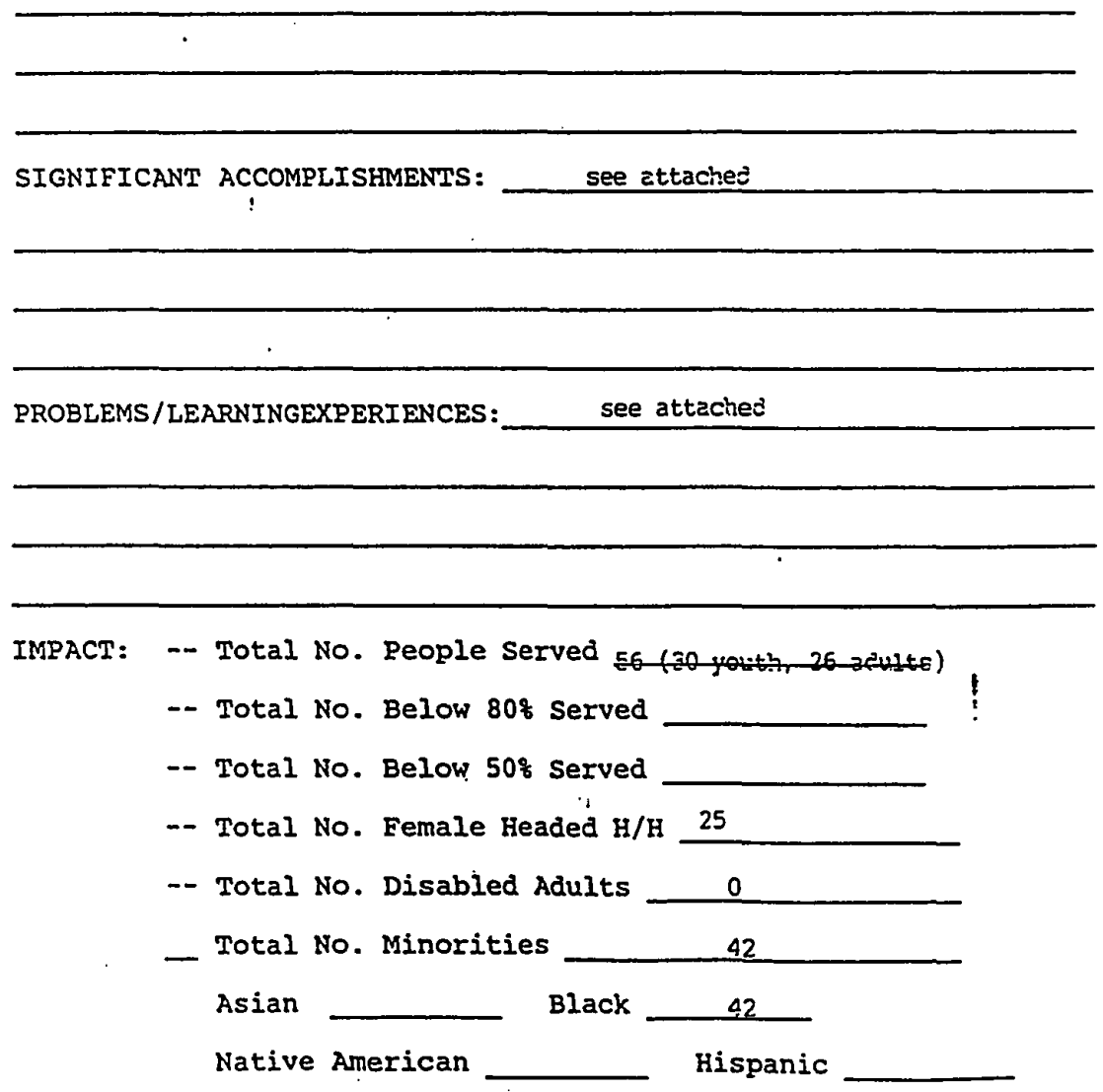

please attach any pertinent materials, press releases, etc. 
NEIGHBORHOOD PARTNERSHIP FUND IRIS COURT COMMUTNITY POLICING DEMONSTRATION PROJECT

submitted by:

HUMBOLDT NEIGHBORHOOD ASSOCIATION

NOVEMBER 20，1990-DECEMBER 19, 1991

PROJECT DESCRIPTION:

Oregon State University Extension Service provides practical education for families and business. For over sixty years OSU Extension Service in Multnomah County, a partnership of county. state and federal government, has provided informal education through workshops, 4-H clubs, consultation, individual and group meetings, and educational bulletins. The "Iris Court community policing Neighborhood Self-Help Demonstration Project" is a partnership between OSU Extension. Portland Police Bureau, Housing Authority of Portland, Humboldt Neighborhood Association, Iris Court Tenant Council, and volunteers living in this community.

"HELPING PEOPLE HELP THEMSELVES", Extension's motto and philosophy, provided the basis of educational experiences in home teaching visits, conducting foods and nutrition classes and field trips, and 4-H/EFNEP club activities at Iris Court. Education programs conducted during this project were primarily "hands on" learning-by-doing experiences. The first phase of the OSU Extension Service/Iris Court Community Policing Project partnership was primarily conducted by the Expanded Eood and Nutrition Education Program (EFNEP).

PROJECT OBJECTIVES:

Elementary age children will:

: Acquire an increased knowledge about health and nutrition.

: Improve their self-esteem and sense of personal competence through involvement in positive group activil̨ies and development of concrete skills.

Parents will:

:Acquire an increased knowledge about health and nutrition.

:Increase their knowledge about food buying, budgeting and emergency food coordination.

Community will:

: Help find adult volunteers willing to be trained in food and nutrition education.

Long term objectives:

:Help Iris Court residents operate their own nutrition program.

:Adult volunteers will provide food and nutrition training for new volunteers.

:Will be involved in planning and conducting other Extension and $4-H$ youth programs. 


\begin{abstract}
SIGNIFICANT ACCOMPLISHMENTS:
The 4-H Youth "Snack Attack" club became too large to meet as one group at Iris Court and was divided into two groups, one for older elementary youth and another for younger children. Many youngsters were responsible for preparing their own snacks, therefore classes emphasized home and kitchen safety, personal hygiene, food safety and sanitation, planning nutritious snacks, and basic food preparation skills.

4-H/EFNEP staff taught 38 food and nutrition club sessions during the year, reaching 30 children. Most club members participated consistently in weekly club activities all year long, bringing the total-number of youth contacts to well over 350 . Most club members also participated in special gardening and food preservation (jam making) experiences as well as an educational field trip to a local super market. Six volunteers helped with the 4-H Snack Attack Club. Some volunteered for more than one session.
\end{abstract}

:FOOD AND NUTRITION LEARNINGS:

: Interviews with members/parents indicated they were using teaching sheets at home in preparing snacks or simple meals.

: Simple format of teaching materials helped reach parents with low reading skills.

-Some specific areas cited were:

:Identifying "high sugar" foods, especially snack foods that are consumed in diets; the amount of sugar found in common processed snack food/beverages; and ways to prepare tasty and nutritious snack foods.

: Learned the importance of good nutrition to health and how to get needed servings from each food group in order to get the most nutritious food for good health.

:Learned ways to use foods received in emergency and commodity food distribution programs to prepare snacks. :Gained an understanding of personal hygiene as it relates to food preparation and good health.

: Learned how to handle kitchen equipment safely. :Gained a better understanding of how to get the best buys at the grocery store. 
:LEADERSHIP/PERSONAL· DEVELOPMENT:

One important goal of 4-H "Snack Attack" staff was to recruit and train volunteer leaders from the Iris Court community to take primary ownership of the club program and continue on with club activities after the grant year ended.

:It has been difficult get long-term leadership commitment from Iris Court residents. However, short term commitments were made as follows:

:Two older elementary age "Snack Attack" members volunteered to assist the club leader in working with the group of younger "Snack Attack" youth for a period of six months.

:Seven adult volunteers were recruited from Iris court as "4-H Snack Attack" "club helpers".

:Four training sessions were needed to train volunteers on nutrition principles, "Snack Attack" curriculum, and on techniques for working with children in group settings.

: Six adults made short term commitments to help with club meeting activities.

:Youth learned how to deal with group conflict situations in a positive manner and to respect others' opinions and property.

\section{:RECOGNITION AND INCENTIVES:}

:Three volunteers worked with 4-H/EFNEP staff to design the T-shirt logo for Iris Court "Snack Attack" 4-H members and volunteers.

:T-shirts were used to recognize Iris Court residents who had made volunteer contributions to the program and to encourage further resident participation in the program. The shirts seemed to give adult volunteers a sense of belonging to a group.

:Members indicated a feeling of pride in belonging to a group in their own community, as well as to a larger youth organization.

:4-H recognition items, kitchen equipment, food boxes, aprons, door prizes and other incentives help EFNEP staff recognize contributions of volunteers and participation in 4-H "Snack Attack"/Adult EFNEP group experiences. 
Adults living at Iris Court were reluctant to become involved in the OSU Adult/EFNEP program. Many had previous contact with other agencies where their involvement had negative associations. The EFNEP staff worked to build trust and confidence by first teaching homemakers lessons in their own homes, and then encouraging homemakers to participate in weekly group lessons held in the Iris Court community room. Summer food preservation classes were conducted there by OSU Master Food Preserver volunteers.

:18 Iris Court homemakers participated in the 13-week adult nutrition curriculum.

$: 7$ homemakers completed all lessons and received graduation certificates.

:5 homemakers learned how to make jam and jelly, preserve peaches, and make pickles.

:FOODS AND NOTRITION:

:Homemakers interviewed indicated they continued to use recipes at home from the EFNEP curriculum.

: Several indicated they had never cooked before. Some had used only convenience-type foods and/or eaten at fast food restaurants.

:Homemakers reported they were taking more time to plan meals for their children. Previously they had let their children do their own food preparation or go hungry.

: Homemakers reported pride in using food preparation skills they had learned in the program. Flipping a pancake was an exciting experience for one homemaker. She had never done it before.

: One homemaker indicated she did not realize that babies should not have soda pop in their bottles. She learned the importance of good nutrition.

:SURVEY OF EFNEP GRADUATES FOLLOWING PARTICIPATION IN PROGRAM: : One had returned to school.

:Five are now employed in jobs or are providing in-home child care to supplement thiir income.

:One homemaker graduated from the teen parent program at Jefferson High School.

:Two who had lost custody of their children were able to regain custody following graduation from EFNEP.

: Several indicated their friendship support dircle had increased as a result of participation in the prodiram. They had felt isolated and alone before. One homemaker indicated that EFNEP graduates were now preparing family meals so they could eat together.

:EFNEP Assistants reported that homemakers took a greater pride in their personal appearance.

:Food recall scores improved from the time homemakers entered and left the program. One homemaker's score improved 40 points.

:All enjoyed involving their children in preparing family meals.

Parenting/discipline that doesn't hurt education programs were offered in several small grouns. EFINEP Assistants indicated that some parents had not had good role models and/or had not had any parenting training.

:Willingness to participate has been slow. Those who have participated have been mery positive about what they have 
EROBLEMS/LEARNING EXPERIENCES:

Long term objectives of helping Iris court residents to operate theit own adult and youth nutrition program are progressing more slowly than anticipated. Families are dealing with a multitude of problems.

:They are involved with many agencies and have to go for appointments that take them away from lessons and time for volunteering.

:Boyfriends (or "significant other") frequently influence whether homemakers can participate in classes.

:The Iris Court community does not get up early. It is hard to schedule classes before noon and then EFNEP Assistants must frequently get homemakers and bring them to classes. Homemakers are interested but don't seem to remember class schedules.

:Self-confidence and leadership skills of potential youth volunteers need to be improved before they will assume responsibility for the $4-\mathrm{H}$ club. There is a willingness to "help", but not to take greater responsibility.

: Reading/comprehension level of $4-\mathrm{H}$ members and parents varied considerably. EFNEP staff developed many new teaching sheets using pictures and large print and. step-by-step instructions to explain how to prepare simple, nutritious snacks. 
APPENDIX $\mathrm{K}$

IRIS COURT NEWSLETTERS 


\section{IRIS COURT PRIDE}

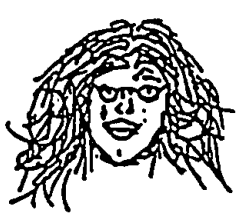
guage that gets immediate attentionI FRE. People gather up their families and valuables and RUN. Smoke detectors have helped save people, which is why there is one in each apartment. At least once a month, please lake the time to check your smoke detectors. The manager can help you check your detector safely. If your detector doesn't work contact your manager immediately, so it can be fixed by Maintenance. Much better to be safe than sorry!II

\section{IRIS COURT GOES TO THE CIRCUS!}

\author{
By Sharmini Joseph
}

On April 3, 57 residents went to the Shriner's Circus. The tickets were donated by individuals through the Housing Authority and the Police Activities League. Transportation was provided by Tri-Met. We really had a good time. The animals were fun to watch. The most exciting part of the circus was the Human Cannonball. A big thank you to the Bee Company for the snacks enjoyed by the kids.

Officers Grady and Johnson enjoyed the circus quite a bit!!

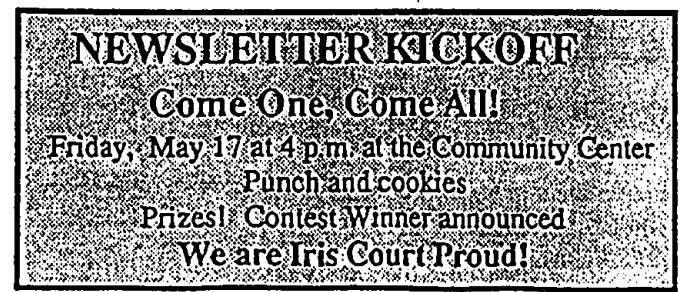

May 1991

\section{PRESIDENT'S PRATTLE}

By Louis Evans, Council President

We in the Hood are proud to be a part of I.C.R.C. and we hope our effort will not be overlooked. We had a joyous time putting this publication together. We came to you asking for help in creating this newsletter. Thanks for your response. I am pleased to know we have this to speak for us. Now we will be heard.

There is much we have planned for the summer, but more info on that later. Your participaiion as a resident will be required. I am asking you NOT to overlook this newsletter. but come forward with your views and ideas. This will make things work. Our community and staff have been wonderful. Thank you for all your efforts and I hope you will enjoy our work on this newsielter. 


\section{COMMUNITY NEWS}

We are sad to report that on March 19, 1991, Linda Graves' son was killed. Miss Graves wishes to thank everyone for their sympathy. Thanks goes out to: Captain Moose, Sylvester, Sharmini, l.eo, Beverly, Ms. Bernice, the Nacoste family and many more.

On March 8, 1991 at noon, there was a dinner for Captain Moose, Sylvester K. and Sharmini to show them how much we appreciate what they are doing for us and our community.

On April 24, Danette Nacost took her younger son, Kenneth B. Morris, Jr. to the doctor and found out that he has to have an operation on his left eye. More info laterl

Deloris Garrison is pleased to announce the marriage of her daughter Jolie King to James E Kemp, son of James and Betty Kemp of NE Portland. Jolie and James will be residing in Olympia, Wash. as James is a Sergeant in the Army.

\section{SUMMER JOBS \\ By Dorothy Kelley}

Project Linkage has job openings for youth between the ages of 16 and 20 . If you can do yard work: mow the lawn, weed, pick up debris, you can make money this summer.

The job runs from June 10 to Aug. 30. Monday -Friday, four hours a day. Pay is $\$ 4.75$ an hour. in most cases, transportation will be provided. For information, call Project Linkage at 249-8215 from 9 a.m. to 5 p.m.or call me, Dorothy Kelley at $249-8102$. There is a bonus for employees who stay until the end of the job at the end of August.<smiles></smiles>

\section{SWAP AND SELL} By Dorothy Kelley

\section{EFNP \\ GRADUATES THREE! By Dottie K.}

The OSU Extension Service had its first three graduates from the Expanded Food and Nutrition Program (EFNP).

Graduation was April 9, 1991. Congratulations to: Dorothy Kelley, Deloris Garrison, and Terri Ellis. Instructors Maureen Quinn and Eleanora Heidelberg invite adults to attend the nutrition class held every Tuesday in the Community Center from 1 to 2 p.m.

Get information on sanitation, proper diet, the nutritional value of food, smart shopping tips, and great recipesIII

Every class prepares a dish relating to the topic of the day. The best part is getting to eat whlat is cooked. All aduits are invited to attend.

Congratulations to Danette Nacoste who graduated April 23.

Want to sell or trade something? Advertise here. Contact the office for more details. 


\section{COMMUNITY POLICING}

By Officer David Grady

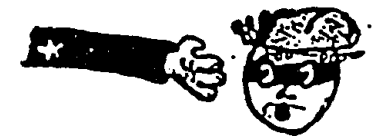

As you know, Sumner Court street was closed. This made Sumner a two-way street with NO PARKING on the north side of the street. It is important to keep the north side of the street for access by the Portland Fire Bureau. Please use the parking lots. If you must use the streets, park your car facing N. Vancouver Avenue.

There have been several cars cited for parking incorrectly and the problem is getting worsel Effective immediately, we will have to start towing automobiles parked in violation of the NO PARKING signs. Please park properly.

\section{SENIOR SPECIAL EVENTS By Emma Carter}

On the second Tuesday of each month, the Senior Uiban League of Portland has a potluck at the Matt Dish. man Community Center. For transportation call Kather Walter at 248-5470.

On June 14, the Seniors' 19th Annual Fishing Derby will be from 9 a.m. to 3 p.m. at Sauvie Island. Cost per person is $\$ 5$, which includes meals and transportation. Meet at the Senior Urban League parking lot at 5523 NE Martin Luther King Boulevard at 8 a.m. The bus will leave at 8:30 a.m.

For more information about these events, call Senior Events Coordinator Kather Walter at 248-5470.

\section{JOB CLUB FORMS \\ By Sharmini Joseph}

On Thursday, May 23 at 3 p.m., come to the Community Center to learn about the formation of the Job Club. We'll talk about: deciding what work you might like to do, putting together a resume, interviewing skills, and filling out job applications.
This is for you if you'd like to: look for work, get a better job, or leam something new.

If you're interested, please let the contact office know at 288-0294, or talk to me. Let's put it together and help anyone that wants a job.

\section{SYLVESTER SAYS...}

By Sylvester Keels, Coordinator

THANKS TO ALL OF YOU, the Iris Count Community Policing Project is going well.

Through the efforts of an enthusiastic Resident Council, the Tenants' Association, and our service providers, we have gotten off to a great start in implementing the "Community Pftrnership" Concept of Community Policing. Help us make our community a better place to live by using the available resources and volunteering some of your time. If you have any questions or if you'd like more informaiton on any of the services we offer, please call 288-0294, 8234068 , or $823-4070$ or drop in at the contact office. 


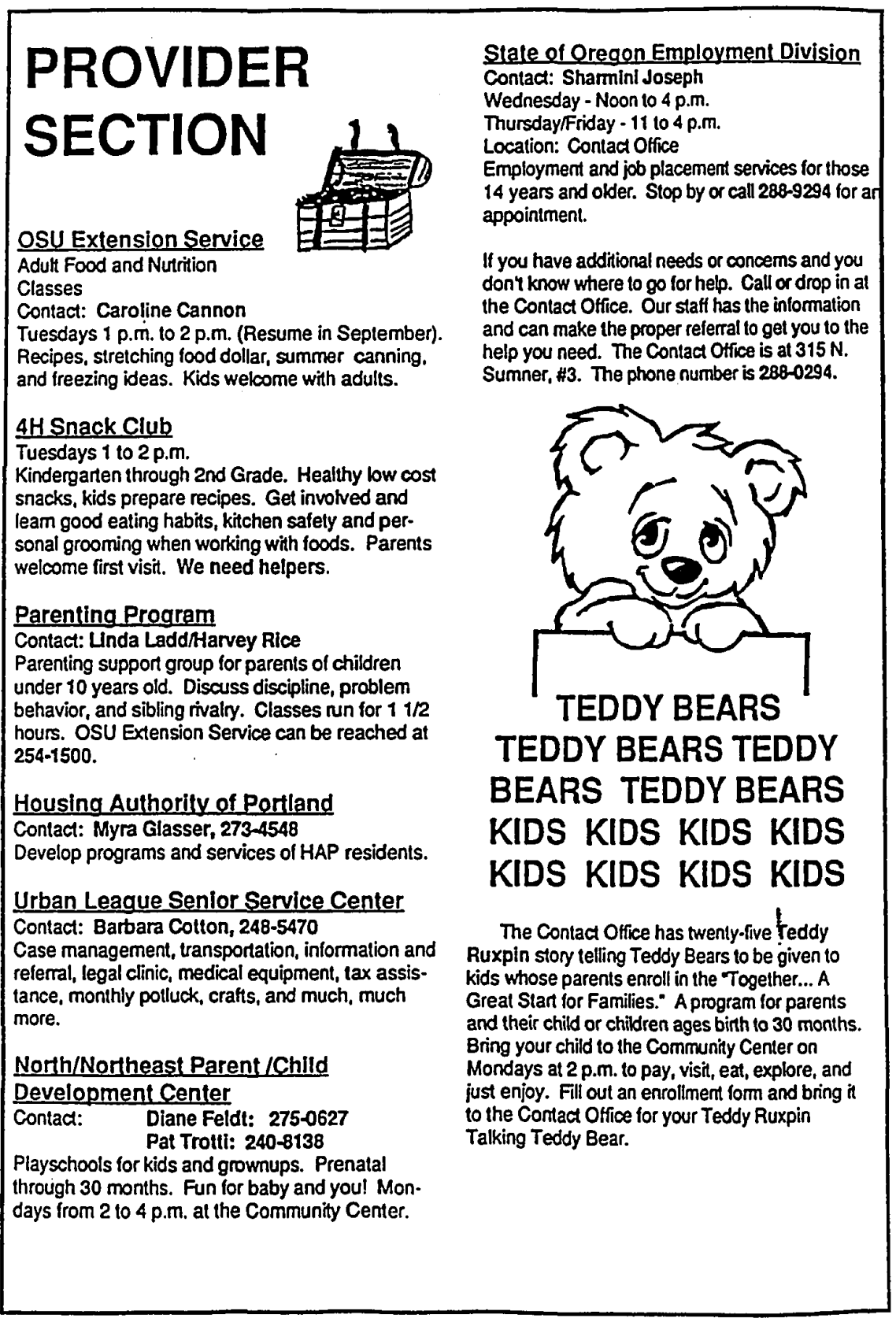




\section{IRIS COURT PRIDE}

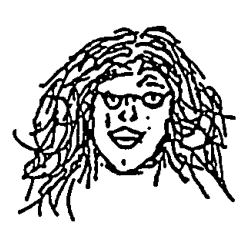

\section{MANAGER'S NOTES}

By Sonnie Fessler

Good news for those of us who love and own pels here at Iris Court. Lisa

Puma, our Community Health Nurse, has offered to give us tips on providing good pet care to our fumy friends.

The class will be held in September, so look for the flyer in your mail slot telling you when and what time.

I strongly urge all ol you pet owners to attend.

Many thanks to Lisa for showing her con cern for all crealures great and small.

\section{COURT KIDS ENJOY PAL CAMP \\ By Officer Scott Johnson}

The week of June 17th to the 21st was a busy and exciting one for 11 year-olds Shawn and Leshawn Beasley and 10 year-olds Frederick Barnum and Phillip Kelley.

They were four of several hundred youngsters who attended the Police Athletic League's (PAL) "Sports Quickness Camp" held at Madison High School.

The boys got speed training in the moming. then put it to work in lootball camp in the afternoon.

Officer Johnson took the boys each morning and coached basketball in the afiernoon.

A special treat was going to breaklast on Thursday, before camp. It was a surprise when the kids had milk shakes for breakfast. The boys had such a good time, and have expressed an interest in attending next year's camp.

\section{SYLVESTER SAYS...}

\section{By Sylvester Keels}

Kids say NO to drugs. At this year's Police Activilies League (PAL) Camp, I taught a class on drug awareness to several hundred enthusiastic 10 to 14 year-olds. We talked about what cocaine was, what effect it has on your body. how you can tell if someone is using cocaine, and what can be done to help someone who is addicted to cocaine.

The kids were particularly interested in myths and tacts centered around cocaine use. They decided that cocaine was not cool or hip. That it does not make you seem older or more confident and "in control." II does not make you more popular and will not make your work tum out better or become easier to do. However, it will damage your brain cells, and produce an insatiable craving for more of the drug. It will ruin your friendships and destroy your family. It will definitely hurt you and may even kill you.

I was surprised at how much the kids knew about drugs and how anti-dng they were. So just like Iris Coun PAL kids, say NO to drugs!

If you or someone you know is using drugs and need help in quitting. please call or come to the Contact Otice. We have a list of agencies that can help you. Your request for help will be held in the strictest of confidence. 


\section{COMMUNITY NEWS}

\section{By Linda Graves and Danette Nacoste}

Some dog owners at lis Court are letting their dogs run loose. The dogs are making a big mess in the children's play areas. The children are walking in the waste and tiny toddlers have been soiled. Dog wastes can spread germs. The children can become ill. EVERYONE WITH A DOG, PLEASE CLEAN UP behind them. The Tenant Council will be asking the Housing Authority to fine anyone $\$ 15$ if they don't clean up after their dog.

A boy was bitten by a dog tied by the play area this late July. So, please do not tie your dogs near the play areas! Do not let your dog nun loose in the complex. This scares some of the kids.

Richard A. Minnifield, Jr. will be celebrating his bitthday on October 6 . There will be more information later.

We are asking that all residents please attend all Resident Meetings. They are scheduled for the last Wednesday of each month. Please support community council members.

We would like to thank everyone who helped with the Rummage Sale and others for supporting it. There will be more Rummage Sales - so watch for the dates!II

For everyone that can work, we need your help in cleaning out the basement in the 400 building for the Halloween party. Please see Unda Graves in 315, Apt. 2, if you would like to help. Come on and get involved.

\section{OTHER COMMUNITY NEWS By Delores Garrison}

Congratulations to newlyweds Michelle Wilson and Donald Gilliland. They were married on Sunday, August 18th.

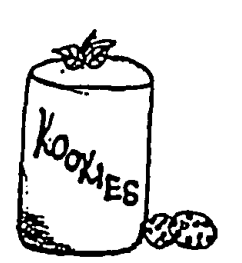

\section{KOOKIE'S KORNER}

\section{PEANUT BUTTER COOKIES}

\author{
1 cup butter or margarine \\ $3 / 4$ cup white sugar \\ 3/4 cup brown sugar (packed) \\ 2 eggs \\ 1 I/2 cups peanut butter \\ 1 Tosp. vanilla \\ 3 cups flour \\ 1 tsp. baking soda \\ 1 tsp. salt
}

Cream together butter and sugars until smooth and creamy. Add eggs and beat until fluffy. Add peanut butter and blend untl smooth and light. Add vanilla and beat until well blended. Combine dry ingredients and add in three parts to creamy peanut butter mixture, beating well after each addition. Roll dough into 1 -inch balls and place on ungreased cookie sheet. Dip a fork in sugar and press cookies in cross top fashion. Bake at $\mathbf{3 7 5}$ degrees for 8 to 10 minutes. Let cookies rest 5 minutes before removing them from cookie sheet. Makes about 5 dozen.

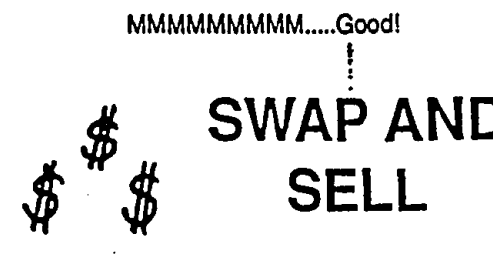

Now is the time for all good neighbors to come to the aid of their neighbors! No one seems to have anything to buy, sell or swap this time..... EXCEPT MEl

I still need a filing cabinet and now I also need a chest of drawers. II anyone has any of these items to sell or trade for ??? Please call me at 249-8215 during the day or 282-7763 on weekends and evenings. 


\section{PROVIDER SECTION}

\author{
RESIDENT RESOURCES GUIDE \\ Do you have a copy? It lists the services \\ available to residents. Names, addresses, and \\ phone numbers, as well as a description of the \\ services provided. If you would like a copy. stop \\ by the Contact office at $315 \mathrm{~N}$. Sumner, $\# 3$.
}

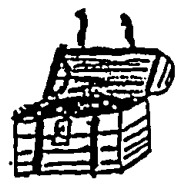

\section{BOYS AND GIRLS CLUB}

For Ages 7 through 14, the club hours are from 3 p.m. to 9 p.m. Monday through Friday. Salurday from 10 a.m. 104 p.m. Club applications are available at the Contact office.

\section{ALBINA MINISTERIAL ALLIANCE \\ (AMA) HEADSTART}

A preschool program for children ages 3 through 5 . Get your applications in early for September. Call 283-1267 for inlormation.

\section{COMMUNITY HEALTH NURSE}

Lisa Puma will see anyone living at Iris Court who has health or other related questions. You can visit in the office or she will visit you in your home. Call 288-0294 if you would like to schedule an appointment. Or, come by and talk when she's around.

\section{OSUEXTENSION SERVICE}

Adult Foods and Nutrition Classes

Contact: Caroline Cannon

Tuesdays 1 p.m. -2 p.m.

Recipes, stretching lood dollars, summer canning, and freezing ideas.

Kids welcome with adults.

$4 \mathrm{H}$ "Snack Attack" Club

Tuesdays 3:30 - 5 p.m. Kindergarten through 2nd Grade

Thursdays 3:30 - 5 p.m. 3rd to 6 th Grade

Healthy low cost snacks, kids prepare recipes and get involved, learn good eating habits, kitchen safety, and personal grooming when working with lood.

Parents welcome first visit. We need helpers.
Housing Authority of Portland

Contact: Myra Glasser, $273-4548$

Develop programs and services tor HAP residents.

\section{Urban League Senior} Service Center

Contact: Barbara Cotton, 248-5470

Case management, transporta. tion, information and referral, legal clinic, medical equipment assistance, tax assistance, monthly pofluck, and crafts and much, much more.

\section{North/Northeast Parent} Child Development

$$
\text { Center }
$$

Contact: Diane Feldt 285-0627

Playschools for kids and grown ups pre-natal through 30 months. Fun for baby and you. More information to come.

\section{State of Oregon}

Employment Division Contact: Sharmini Joseph Wednesday, Nobn to 4 p.m. Thursday/Friday, 11 ' to 4 p.m. Location: Contact Office Employment and job placement services for those 14 years and older. Stop by or call 288-0294 for an appointment.

\section{Parenting Program}

\section{Contact Linda Ladd}

Parenting support group for parents of children under 10 years old. Discuss discipline, problem behavior, and sibling rivalry. Classes run for 1 1/2 hours. OSU Extension Service can be reached at 254-1500. 
APPENDIX L

INTERVIEW TRAINING GUIDELINES 
COMMUNITY POLICING DEMONSTRATION PROJECT NORTH PRECINCT INTERVIEW TRAINING

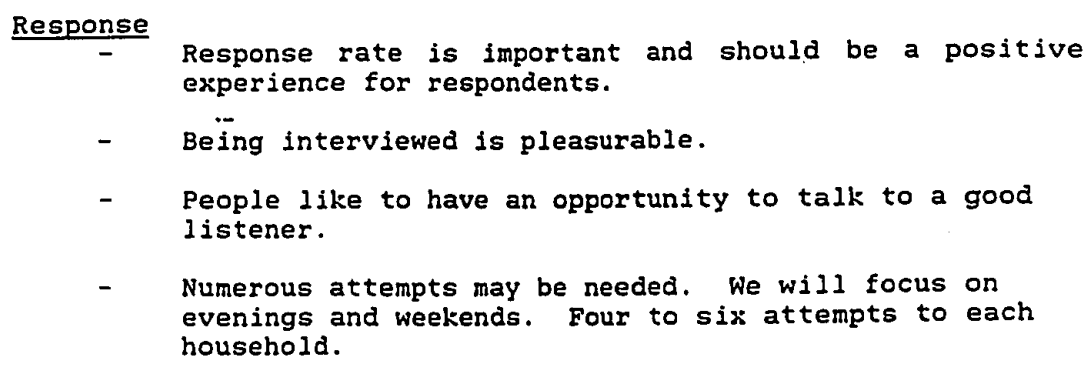

- Numerous attempts may be needed. We will focus on evenings and weekends. Eour to six attempts to each household.

Role of Interviewer

1. Locate and gain the cooperation of the respondents.

2. Motivate respondents to answer.

3. Be a good question asker and answer recorder.

4. Maintain a consistent style.

How do you fulfill these roles?

1. Be confident. Be assertive (not aggressive). There should be no doubt in your mind that the respondent wants to answer.

2. Do not rush. Show your willingness to listen. Encourage response.

3. Ask questions in clear tone, repeat if needed.

4. Present the survey with the same lead-in each fime. Ask the questions exactly the way the are written. If the answer is incomplete, use the following standard probes:

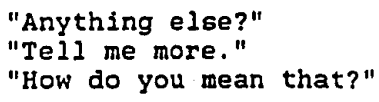

- Do not tell stories about yourself or express any views or opinions. Do not communicate any judgements on 
Page Two

- Be friendly, but behave as a professional, not a friend.

\section{The Actual Interview}

- Who do you represent?

You are representives of the Office of Neighborhoods. Not your individual neighborhood, but simply the office of Neighborhoods, City of Portland.

- Who do you not represent?

you do not represent the Portland Police Bureau.

you do not represent the Housing Authority of Portland.

you do not represent Multnomah County.

you do not represent the welfare of $f$ ice.

\section{Instructions to Respondent}

Before we start. let me tell you a $11 t+1$ e b1t about the interview process. You will be asked two kinds of questions in this survey.

One - I will be asking you to answer questions in your own words. In those cases. I will have to write down every word you say.

Two - I will be asking you questions that have a given set of answers and you will be asked to choose the one that is closest to your own view. Even though none of the answers may fit your ldeas exactly. choosing the response closest to your views will enable us to compare your answers more easily with those of other people.

Why are we doing this survey? DO NOT GIVE THIS INFO TO RESPONDENTS!!!!

The Portland Police Blireau is into a five yeat Transition Plan of Community Policirg. This! demonstration project is one of three projects being done to evaluate what methods and strategies are successful and which are not successful. Part of the evaluation includes this survey.

The survey is to be glven prior to the implementation of the project. It will be given again (exact same survey) at the end of one year. The data w1ll abe coded. studled, disputed, reviewed and analyzed.

The information is designed to help us become BETTER at Community Policing. 
APPENDIX M

PROJECTS BY THE COMMUNITY HEALTH NURSE 


\begin{tabular}{|c|c|c|}
\hline $\begin{array}{l}\text { OEPARTMENT OF HUMAN SERMCES } \\
\text { HEALTH OMSION } \\
\text { NORTHEAST HEALTH CENTER } \\
\text { S329 N.E MARTIN LUTHER KING JR. BLVD. } \\
\text { PORTLNDD. OREGON } 97211 \\
\text { (503) } 248-5183\end{array}$ & $\begin{array}{l}\text { ADULT/PRENATAL } \\
\text { PEDS/WIC } \\
\text { FIEL.D SERVICES } \\
\text { DENTAL }\end{array}$ & $\begin{array}{l}\text { BOARD OF COUNTY COMMISSIONERS } \\
\text { GLAOYS MCCOY - CHAIR OF THE BOARD } \\
\text { PAUUINE ANDERSON : OISTRICT I COMMISSIONER } \\
\text { GARY HANSEN - OISTRICT } 2 \text { COMMISSIONER } \\
\text { RICK BAUMAN - OISTRICT } 3 \text { COMMISSIONER } \\
\text { SHARRON KELLEY - OISTRICT } 4 \text { COMMISSIONER }\end{array}$ \\
\hline
\end{tabular}

January 3,1991

Dear Connie:

The following is a compilation of our efforts to begin to meet the goals of the Iris Court Community Policing grant for 1991. The information presented is specific to the CHN position as it relates to the project. The goal of this effort has been to:

Clarify and inventory $\mathrm{CHN}$ activities in the past year as they relate to the grant/support the grant's goals.

Place activities/projects together rather than placing the information chronologically to better see progression.

Provide a visual report of our work to be available for review, and to interested persons.

Evaluate areas which need more energy and planning.

Assist in the development of performance objectives for 1992 .

The review brought to mind long hours spent defining/ streamining the various forms and correspondence. Your commitment to this project is appreciated, and your input, indispensable.

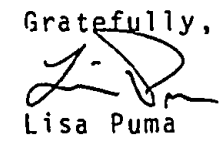

AN EOUAL OPPORTUNITY EMPLOYER 


\section{Iris Court Complex \\ Community Policing Project \\ Community Health Nurse}

The Cammity Health Nurse (CHN) position at.Iris Court is the result of a collaborative effort between the City of Portland Police Department and the Mulmanah County Health Division. The CHN is a member of the Northeast Health Center Field Team, and is responsible for providing services to the Iris Court Cammity Policing Project.

The CFN works to rebuild the commmity by working with the individual in THEIR enviroment. The focus is on decreasing family dysfunctional behaviors which result from underlying physical, emotional, mental and social problems. This task is met by conducting individual and familv assessments, providing short-term guidance, and follaving resident's progress to assure needed care.

The CHN at Iris Court places emphasis on self-esteem building through the development of healthy coping skills. The nurse is working to open doors to drug abuse prevention information and treament opportunities for those persons ready for a positive change to occur in their lives.

Other programs available to Iris Court Complex Residents tirrough Multnomah County Health Division include classes about childbirth, diabetes, drug and alcohol treatment, screenings for SID's ( sexually transmitted diseases). well-child care, pre-natal care, and WIC services. The WIC ( Women, Infant, CHildren) program provides nutritional care and supplements to pregant and postpartur women and their infants. The Iris Court CrN invites supports and often coordinates the involvement of other agencies in meeting the needs of the residents. On-site support groups that address pertinent issues are being developed with the cooperation and participation of specific local agencies that share the goal of empowering people living in the Iris Court Complex.

Submitted By:

Lisa Puma; RN, Community Health Nurse

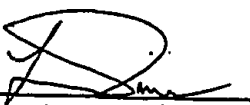
iMunaman:Courty :

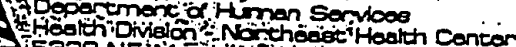

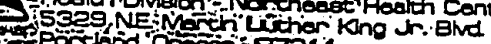
\%ớland

. (503) 2405055 .
Date:

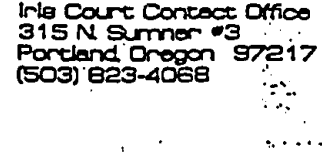




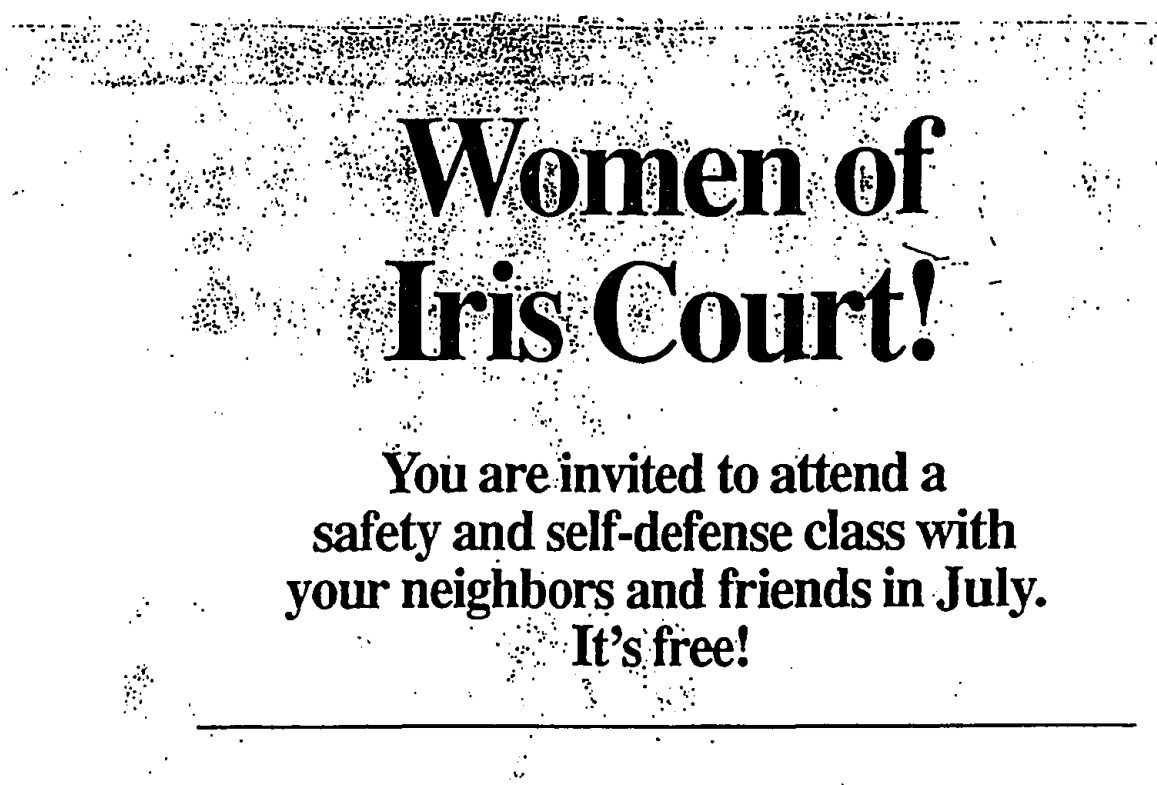

Monday, July 1; Wednesday, July 3; and Monday, July 8 (plan to attend all three!)

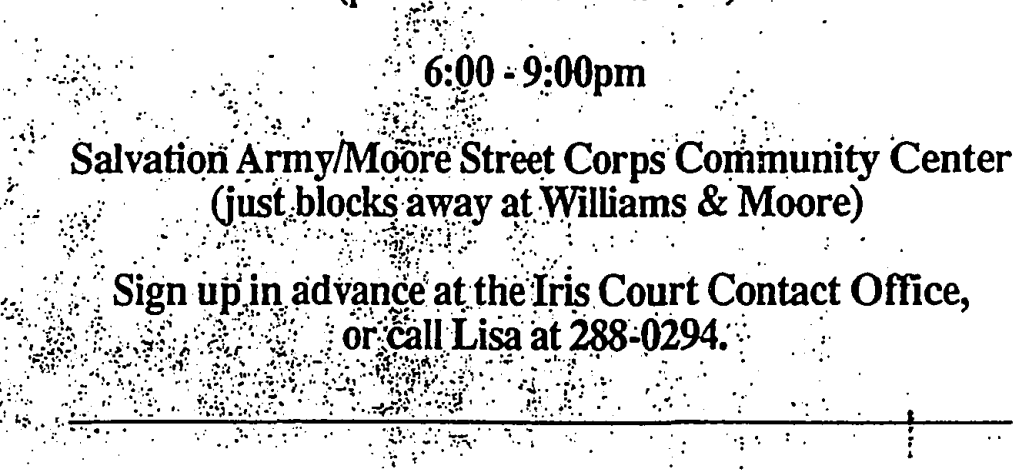

This class is taught to teenage and adult women

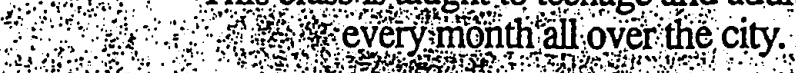

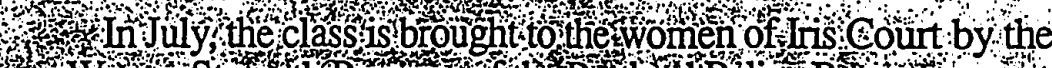

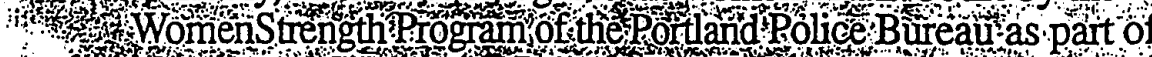

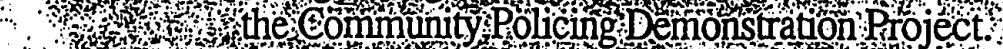




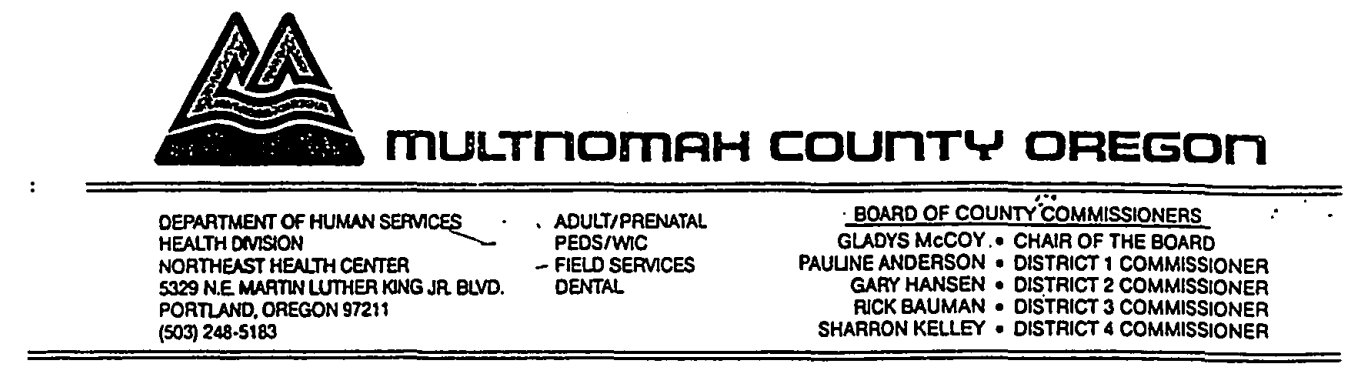

August 13, 1991

Myra L. Glasser

Resident Services Coordinator

135 S.W. Ash St.

Portland, OR 97204

Dear Ms. Glasser:

There have been noteworthy changes at Iris Court since the establishment of the on-site Resident Council. This has shifted responsibility from the providers to the residents of Iris court and implementated resident-focused activities.

The participants of the Resident Council are motivated to improve the quality of life for themselves and their peers. This was demonstrated by the planning and follow through of an off-site pienic, bake and rummage sale, and a bi-monthly newsletter.

The Resident Council could be further empowered if provided with bette tools to meet the task of rebuilding their community. Often, the cour. cil is bogged down with difference of opinions, and with attempts to si realistic goals around projects. A lack of knowledge in group process results in time and energy waste.

Training in group process techniques and conflict resolution would provide the Council with the skills necessary to overcotne obstacles when individuals are committed to reach a group concensus on issues which directly affect their lives.

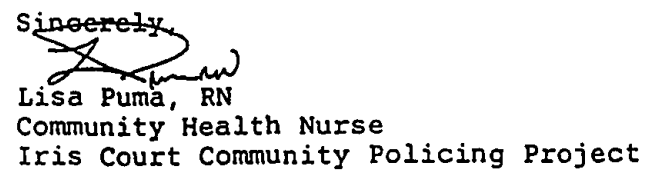

LP/ly 


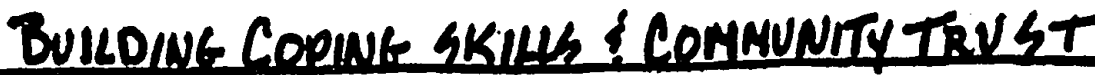

BACKGROUNO

Unlike the enemy in a traditional war, drugs do not "invade" by attacking our geographic borders. Rather, drugs "invade" by cutting the fabric of our society in places where we nave allowed it to wear thin. Alone, law enforcement cannot. win this kind of war. To. win, we must rebuild the fabric of our communities worn down by cycles of dependency, loss of hope ond feelings of futility, alienation, and feor. This is a proolem oorn of changes that nove weakened the strength of our society. It will be solved through efforts that bring that strength back.

Effective demend reduction strategies provide short-term results and leave behind a faundation for long-term prevention. Effective strategies ease the symptoms, but target the cause.

We have mapped out an ambitious process for ochieving longterm demand ceduction that goes beyond one year's implementation. He are requesting grant finding to help lay the foundation for that process. While much will be accomplished in the first year, our overriding gool is development of solutions that can grow in impoct in the years that follow. In developing our goals for the innovations under this grant, we set the following sgende:

1. Fach strategy must offer short-term deinand reduction results.

2. Each stcategy must be a catalyst for increased involvement in community problem solving by people who did not previousIy participate, thus laying the foundation for longer term demand reduction.

3. Each stcategy must contribute to a shift in attitude from government providing services to people, to citizens devedoping solutions with government.

4. Each strategy must adoress a different layer of the orug and drug-crime problem.

5. Implementation of the process must balance technical oversight with decentralized management; community-based solutions cannot be achieved unless we allow management by those who ace oirectly involved. 
285

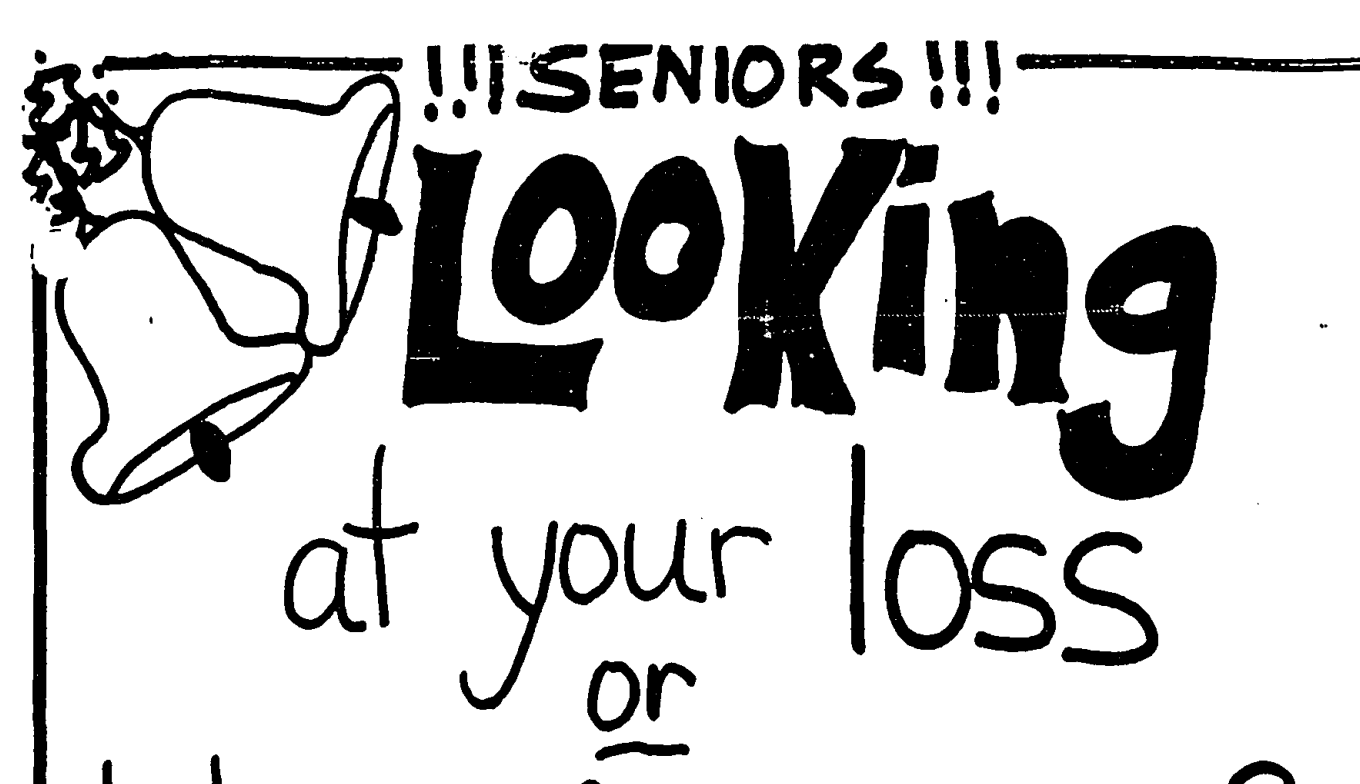

helping a friend $\multimap$

Thursday, Dec. 5 TH

- Presented By...

\$2:00pm-3: 00pm - Pam Brandon, R

* Community Room - Little Chapel

Coffee cake of the Chimes for seniors 
Iris Court Complex

Community Policing Project

Community Health Nurse

\section{Group Activity Information}

\begin{tabular}{|c|c|c|c|c|}
\hline \multicolumn{2}{|c|}{ ACTIVITY NAME: } & \multicolumn{3}{|c|}{ Children's Christmas Decoration Making } \\
\hline \multicolumn{2}{|c|}{ Community Need: } & \multicolumn{3}{|c|}{$\begin{array}{l}\text { Children working together to contribute to the Iris } \\
\text { Court Community Christmas party. Recognition for their } \\
\text { efforts. }\end{array}$} \\
\hline \multicolumn{2}{|c|}{ Goal of Activity: } & \multicolumn{3}{|c|}{$\begin{array}{l}\text { Children will learn by discussion, cultural values } \\
\text { around Christmas. Will practice cooperation, listening } \\
\text { and sharing skilis. }\end{array}$} \\
\hline \multicolumn{2}{|l|}{ Agency: } & \multicolumn{3}{|c|}{ Iris Court Community Policing Demo Project } \\
\hline \multicolumn{2}{|c|}{ Contact Person: } & \multicolumn{3}{|l|}{ Lisa Puma, R.N. } \\
\hline \multicolumn{2}{|c|}{ Activity Description: } & \multicolumn{3}{|c|}{$\begin{array}{l}\text { Explanation of the task at hand, demonstrated task, } \\
\text { supervised task of making decorations from paper, } \\
\text { glue for the Office and I.C. Christmas party. } \\
\end{array}$} \\
\hline \multicolumn{2}{|c|}{ Target Population: } & \multicolumn{3}{|l|}{ Children of all ages. } \\
\hline $\begin{array}{c}\text { Date Activity } \\
\text { Occurred }\end{array}$ & \multicolumn{2}{|c|}{ Time } & Facilitator & $\begin{array}{l}\text { Number of } \\
\text { Participants }\end{array}$ \\
\hline $12 / 12 / 91$ & $\begin{array}{l}3: 00 \mathrm{pm}- \\
4: 10 \mathrm{pm}\end{array}$ & $\begin{array}{l}\text { Iris Court Contact } \\
\text { Office. }\end{array}$ & Lisa Puma & 4 \\
\hline
\end{tabular}

Submitted By

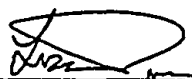

Lisa Puma, RN, Community Health Nurse

Date:

$12 / 13 / 91$

Muknomah Councy

Dopartument of Himan Services

Hoalth Divialon - Norcheast Hoalth Center

5329 NE Mareh Luchar King it. Blvd

Portland Orogon G7e1 1

(503) 240-5055

19199

Multnomah County does not discrininate on the basts of race, color, national origin,

sex, religion, age, and handlapped status in employment or the proviston of servicas.

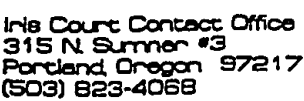

$315 N$ Smriner

97217

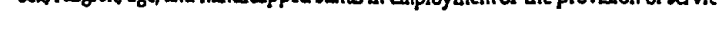




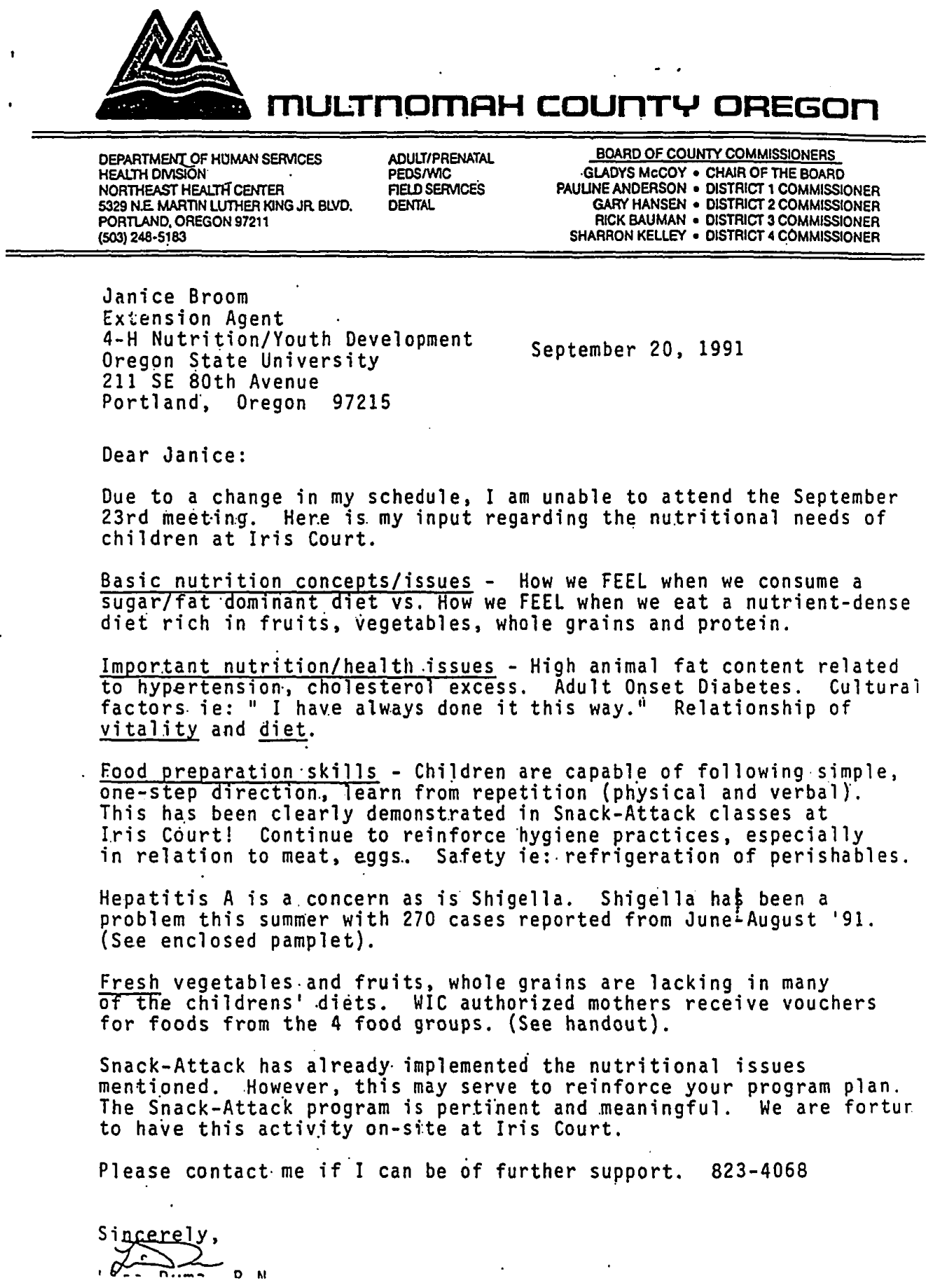




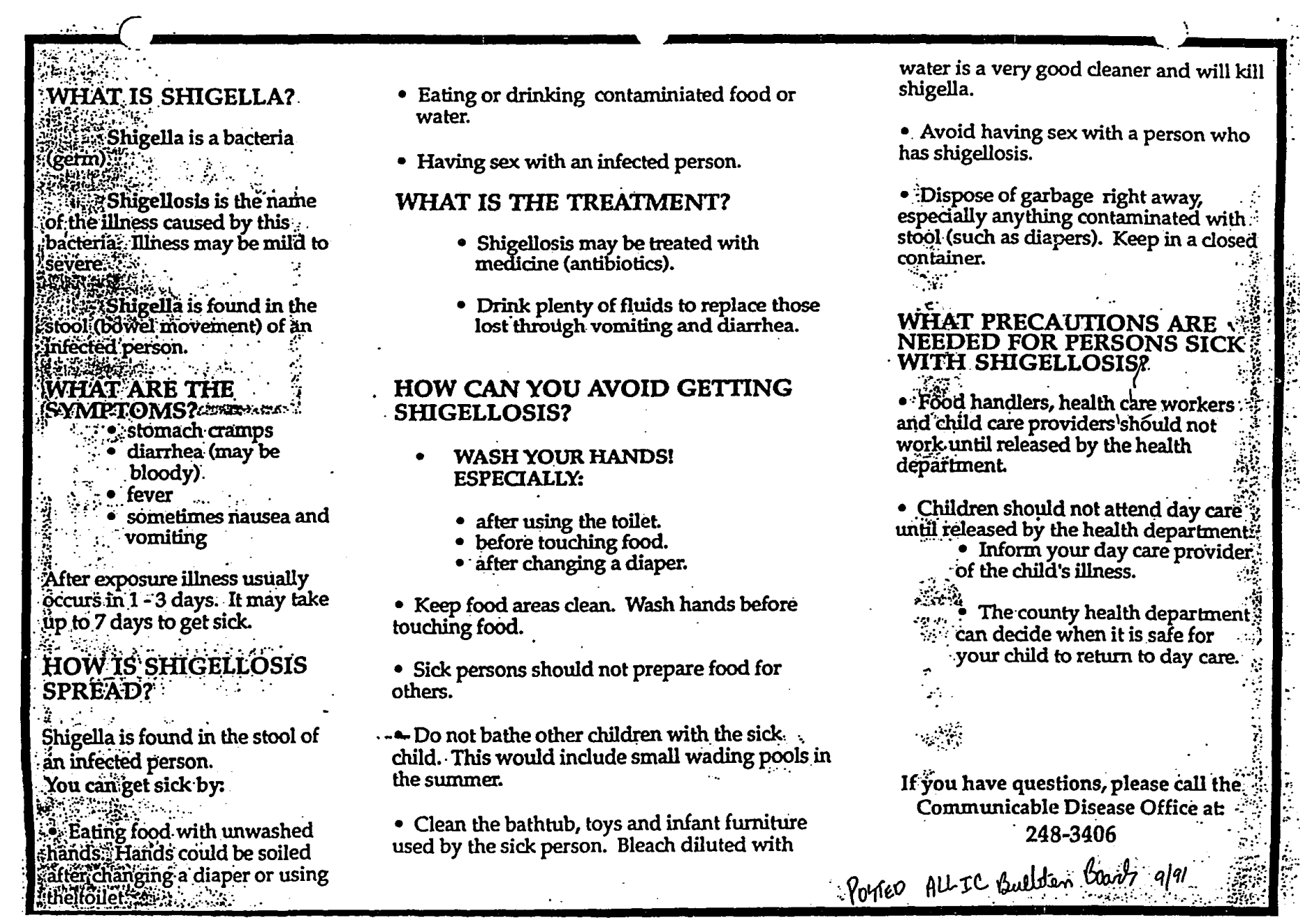




\section{muLTnOMAH counTy OREGon}

OEPARTMENT OF HUMAN SERMCES

MEALTH OMSION

Iris Court Community Policing Project

NORTHEAST HEALTH CENTER

5329 NE MARTN LUTHER KING JR BLVD.

Lisa Puma, R.N.

PORTLAND. OREGON 97211

Community Health Nurse

(503) 248.5183

\section{Activity Information}

ACTIVITY NAME: TENANTS ASSOC MTIULL

Community Need:

SYRIMGE DISPOSAL/SAFETy INUSDRMOTON

Goal of Activity: REINACCE SAFE DISPOSA OF SYRINGES WTH60OO COMPREHENSION

Agency and

LISA PUMA (5-10 MIN PRESENTATIOU)

Contact Person: HBRRIGOS DANLEY, MAINGTREAM 45 MIN PRESENTMTION

SYLVESTER HEELS 15 MIN PRESENTITION

Activity Description: DEmONSTEATEO PROPER PROTOCA FOR OSPOASAL OF

Age Range:5 ANO UP SYRINIES

\begin{tabular}{|c|c|c|c|c|}
\hline $\begin{array}{c}\text { Date Activity } \\
\text { Occurred }\end{array}$ & Time & Location & Facilitator & \#participan: \\
\hline $10 / 7 / 91$ & $5^{\mathrm{Pm}} \mathrm{g} \mathrm{Pm}$ & $\underset{\text { Room }}{\text { Communi-y }}$ & $\begin{array}{c}\text { SYCUESTER } \\
\text { HEELS }\end{array}$ & $/ 4$ \\
\hline
\end{tabular}

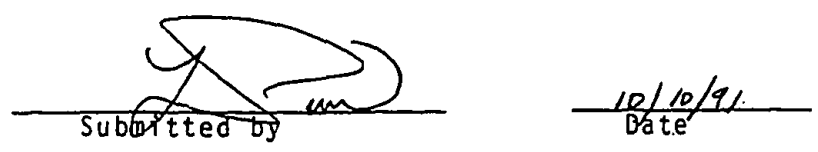


290

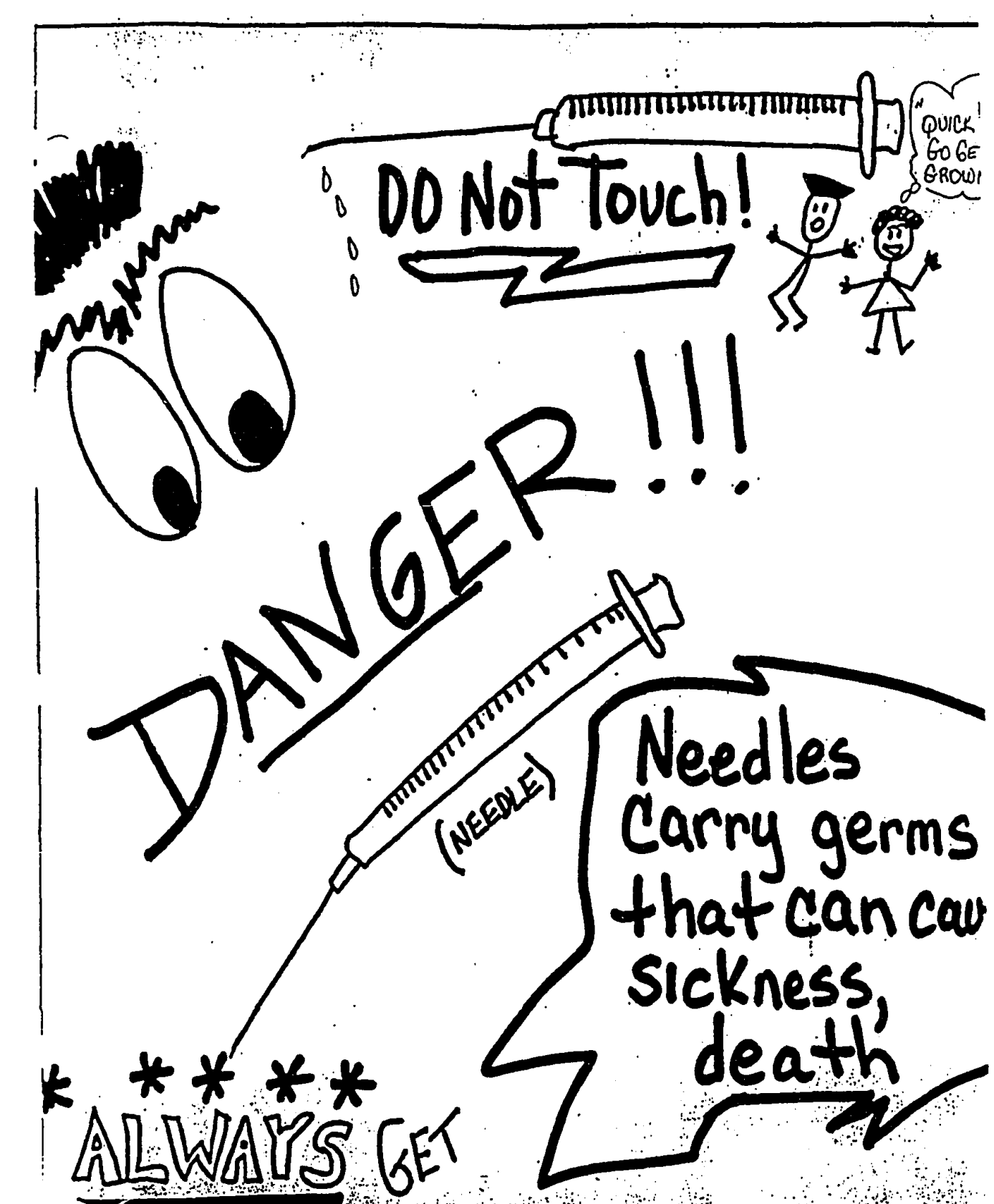

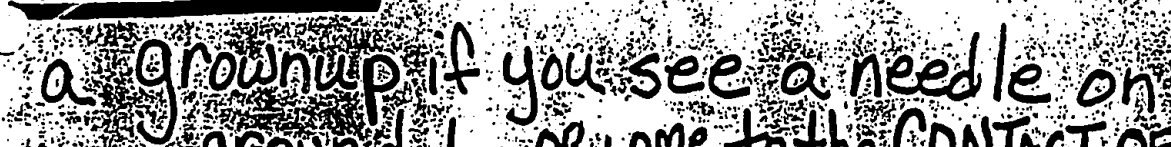




\begin{tabular}{|c|c|c|}
\hline $\begin{array}{l}\text { DEPARTMENT OF HUMAN SERMCES. } \\
\text { HEALTH ONISION } \\
\text { NORTHEAST HEALTH CENTER } \\
\text { 5329 N.E. MARTN LUTHER KING JR BLVD. } \\
\text { PURTLAND. OREGON } 97211 . \\
\text { (503) } 248-5183\end{array}$ & $\begin{array}{l}\text { ADULT/PRENATAL } \\
\text { PEDS/WIC } \\
\text { FIELD SERMCES } \\
\text { DENTAL }\end{array}$ & $\begin{array}{l}\text { BOARD OF COUNTYCOOMMISSIONERS } \\
\text { GLADYS MCCOY - CHAIR OF THE BOARO } \\
\text { PAULINE ANDERSON : OISTRICT I COMMISSIONER } \\
\text { GARY HANSEN - OISTRICT } 2 \text { COMMISSIONER } \\
\text { RICK BAUMAN : DISTRICT } 3 \text { COMMISSIONER } \\
\text { SHARAON KELLEY - DISTRICT } 4 \text { COMMISSIONER }\end{array}$ \\
\hline
\end{tabular}

August 14, 1991

Dick Jones

Maintenance Coordinator

Housing Authoriety of Portland

$8910 \mathrm{~N}$. Woolsey

Portland, OR 97203

Dear Mr. Jones:

I am responding to your request to help you develop protocol aimed at preventing unintentional needle sticks. I am glad to hear you have protocol around blood spills in place. This makes my job easier. I have gathered some information. Enclosed is a list of resources and training about sharp disposal, information on types of Infectious waste, EPA/OSHA definitions, and Oregon House Bill 2865, a law regulating infectious waste.

I hope this information will be of service to you. Please contact me when the need arises. I am happy to consult with you as you deveio and implement this project. I can be reached at 248-5055 or 823-4068 Thank you for your request and interest in this project.

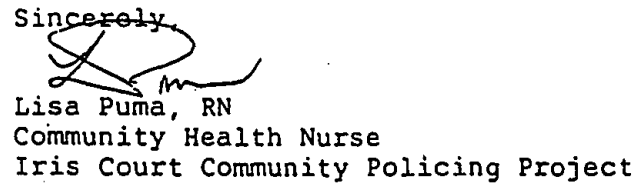

LP / Iy

Enclosures 


\section{mULTIOMAH COUחTY OREGOח}

DEPARTMENT OF HUMAN SEFMCES HEALTH OMSION

NORTHEAST HEALTH CENTER 5329 NE MAATIN LUTHER KING JR BLVO. PORTLANO. OREGON 97211 (503) 248-5183
Iris Court Community Policing Project

Lisa Puma, R.N.

Community Health iNurse

Activity Information Form

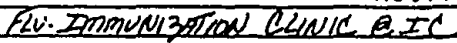

PROTECTION FROM FUL BY IMMUUi3RTION IN A PLACE EASILY ACCESSIBLE TO RESIDENTS OF IRIS COURT- Q AN ALFRDARE CoST

Goal of Activity: IMMUNIZATION OF ALL APPROPRIATE RESIDEATS WHO WISH TO HAUE THE SERUICE-

\begin{tabular}{|c|c|c|}
\hline $\begin{array}{l}\text { Agency and } \\
\text { Contact Person: }\end{array}$ & $\begin{array}{c}\text { MULTNOMAH COUNTY HEATTH DIVIGION } \\
248-5055\end{array}$ & $\begin{array}{l}\text { - TERRY LONOOS, CHN, } \\
\text { CHRISTIE TRYLR CHN } \\
\text { LORENA YOUNG }\end{array}$ \\
\hline
\end{tabular}

Activity Description: TEACHIN, INTERUEU AND IEMMUNIzBTION OF PEOPLE Age Range: aER 65, OR WIHH CHRONC IULVES (SEE ENCLOSEO)

\begin{tabular}{|c|c|c|c|c|}
\hline $\begin{array}{c}\text { Date Activity } \\
\text { Occurred }\end{array}$ & Time & Location & Facilitator & \#participan. \\
\hline $\begin{array}{l}\text { MONOAY } \\
\text { OCTOBER } \eta^{T H}, 1991\end{array}$ & $\begin{array}{l}10.00 \mathrm{Am}- \\
12.00 \mathrm{pm}\end{array}$ & $\begin{array}{l}\text { Communisy } \\
\text { Room }\end{array}$ & LISA RUMA LIN & 5 \\
\hline
\end{tabular}

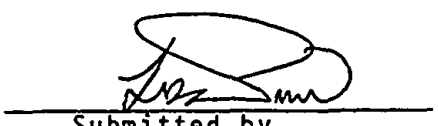

Submitted by 


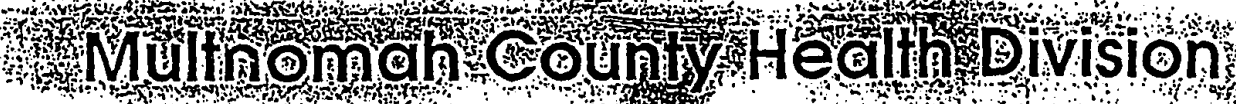

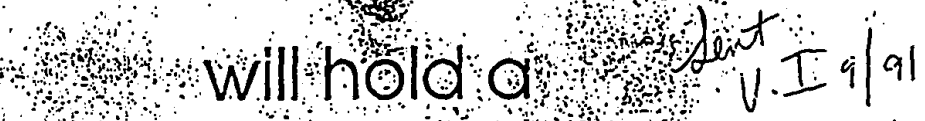

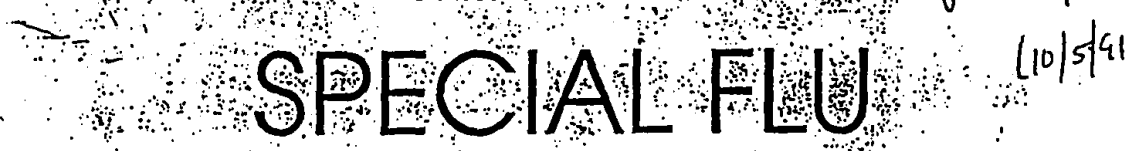

$$
\begin{aligned}
& \text { IMMUNIZATION CLINIC }
\end{aligned}
$$

\author{
for
}

persons over 65

People with chronic health problem: Caregivers/Providers

Dater $\rightarrow$ MONDAY OG: T:H

Time $10.00 \mathrm{Am}-12 \mathrm{NoON}$

LoeGHON. COMMUNTI ROOM

\title{
Cost . $\$ 600$
}
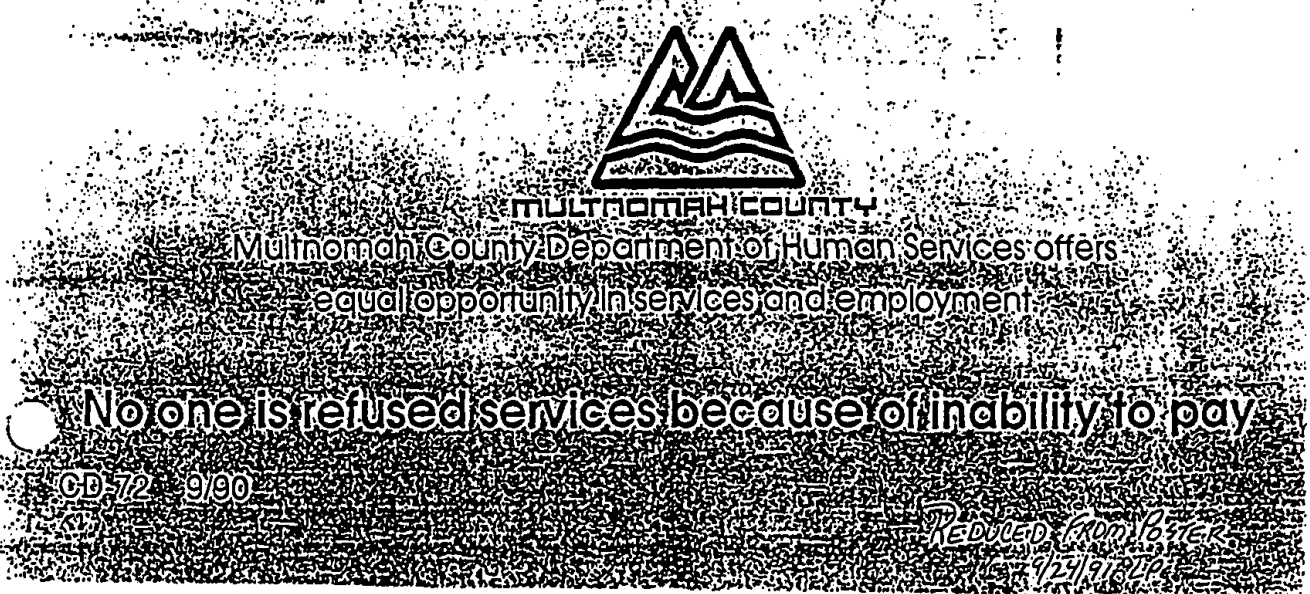


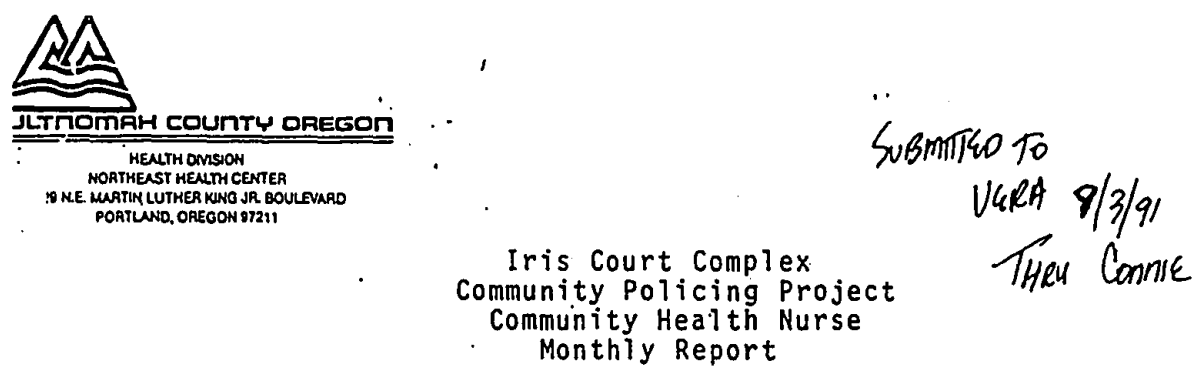

\begin{tabular}{|c|c|c|c|c|c|c|}
\hline WEEK ENDING: & $8 / 2191$ & $8 / 9191$ & $8 / 16 / 91$ & $8 / 23 / 91$ & $8 / 30 / 91$ & TOTA \\
\hline REFERRALS RECEIVED & 1 & $\theta$ & / & 1 & - & 3 \\
\hline $\begin{array}{l}\text { CLIENTS OPENED TO } \\
\text { CASE MANAGEMENT }\end{array}$ & $\theta$ & 2 & 1 & $\varnothing$ & & 3 \\
\hline $\begin{array}{l}\text { ONE-TIME/SINGLE } \\
\text { ENCOUNTERS }\end{array}$ & 17 & 10 & 12 & 4 & 5 & $10=$ \\
\hline $\begin{array}{l}\text { CLIENTS CLOSED TO } \\
\text {.ASE MANAGEMENT }\end{array}$ & $\theta$ & 2 & $\theta$ & $\varnothing$ & है & 2 \\
\hline PRESENT CASELOAD & 10 & 10 & II & $/ /$ & $\frac{5}{2}$ & // \\
\hline HOME VISITS & 3 & 2 & 5 & 3 & 4 Sह & 17 \\
\hline OFFICE VISITS & 1 & 1 & $\varnothing$. & 1 & & 3 \\
\hline NO-SHOW VISITS & 2 & 2 & 1 & $\varnothing$ & $!$ & 5 \\
\hline $\begin{array}{l}\text { REFERRALS OUT TO } \\
\text { OTHER AGENCIES/ } \\
\text { PROVIDERS }\end{array}$ & $\varnothing$ & I Jiviorlowace & I UNA UKRmis & 2ywCA & (a) & 4 \\
\hline $\begin{array}{l}\text { NON-CLIENT } \\
\text { CONSULATIONS }\end{array}$ & 2 & 2 & 3 & 5 & $20^{2}$ & 32 \\
\hline :LASSES/GROUPS & $\varnothing$ & $====$ & OUTRexeH $\times 2$ & $==$ & & \\
\hline ATTENDANCE & & & 10 & $N / A$ & 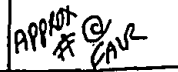 & \\
\hline
\end{tabular}

